\begin{tabular}{|c|c|}
\hline AUG 301998 ENGINEERING DATA TRANSMITTAL & 1. EDT $6176 \frac{1}{27}$ \\
\hline
\end{tabular}

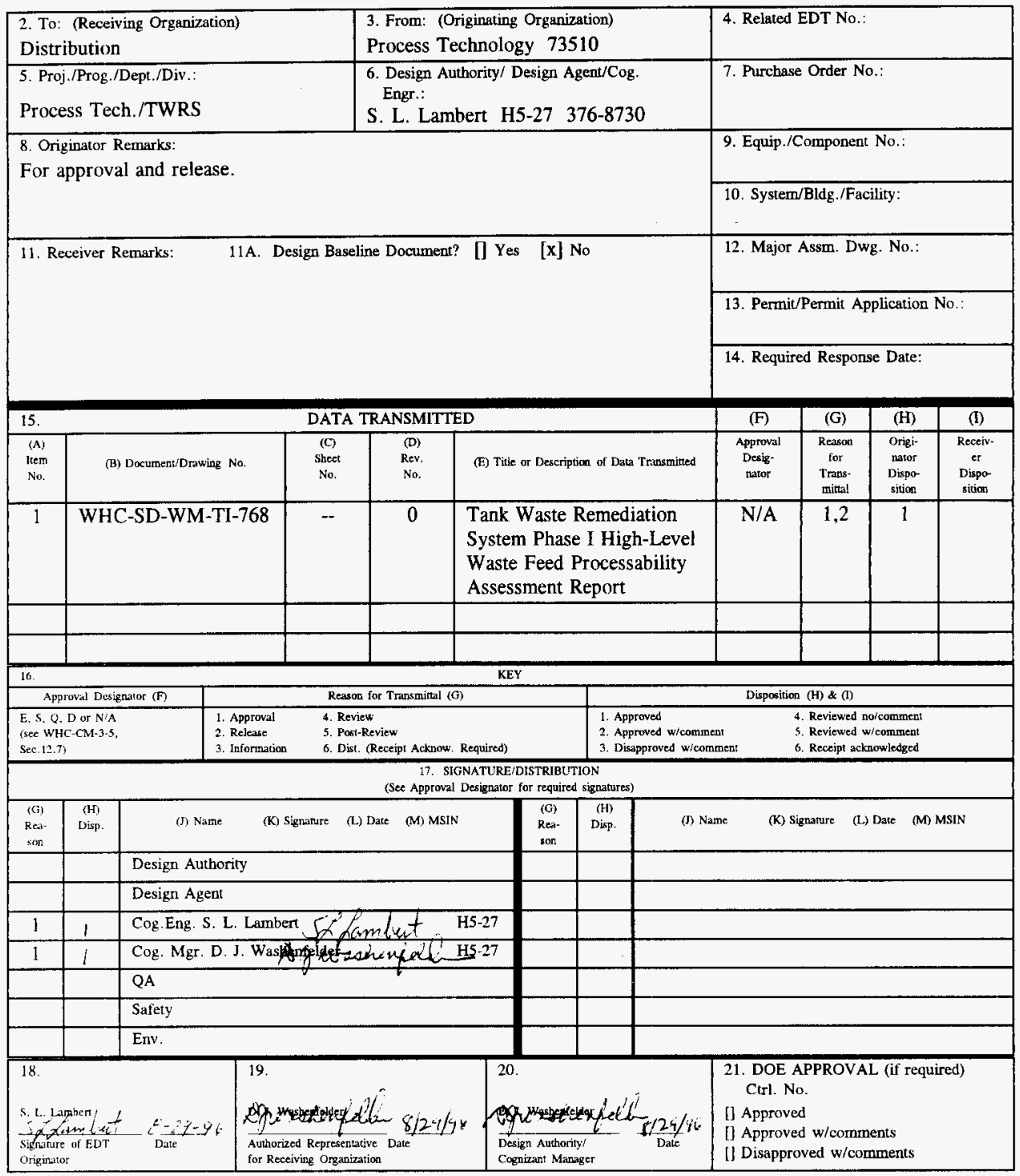




\title{
Tank Waste Remediation System Phase I High-Level Waste Feed Processability Assessment Report
}

\author{
S. L. Lambert, G. E. Stegen, and J. D. Vienna (PNNL)
}

Westinghouse Hanford Company, Richland, WA 99352

U.S. Department of Energy Contract DE-ACO6-87RL10930

\author{
EDT/ECN: 617627 \\ Org Code: 73510 \\ UC: 721 \\ B\&R Code: EW3130010 \\ Charge Code: D5224 \\ Total Pages: 205203
}

Key Words: high-level waste, HLW, feed processability, TWRS, Phase I

Abstract: This report evaluates the effects of feed composition on the Phase I high-level waste immobilization process and interim storage facility requirements for the high-level waste glass. Several different Phase I staging (retrieval, blending, and pretreatment) scenarios were used to generate example feed compositions for glass formulations, testing, and glass sensitivity analysis. Glass models and data form laboratory glass studies were used to estimate achievable waste loading and corresponding glass volumes for various Phase I feeds. Key issues related to feed processability, feed composition, uncertainty, and immobilization process technology are identified for future consideration in other tank waste disposal program activities.

TRADEMARK DISCLAIMER. Reference herein to any specific commercial product, process, or service by trade name, tradenark, manufacturer, or otherwise, does not necessarily constitute or imply its endorsement, recommendation, or favoring by the United States Government or any agency thereof or its contractors or subcontractors.

Printed in the United states of America. To obtain copies of this document, contact: WHC/BCS Document Control Services, P.O. Box 1970, Mailstop H6-08, Richland WA 99352, Phone (509) 372-2420; Fax (509) 376-4989.
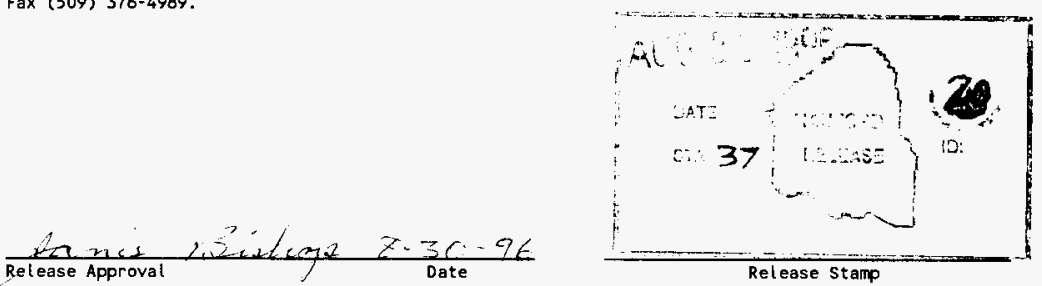

\section{Approved for Public Release}




\title{
TANK WASTE REMEDIATION SYSTEM PHASE I HIGH-LEVEL WASTE FEED PROCESSABILITY ASSESSMENT REPORT
}

August 1996

\author{
S. L. Lambert \\ G. E. Stegen \\ Westinghouse Hanford Company \\ Richland, Washington \\ J. D. Vienna \\ Pacific Northwest National Laboratory \\ Richland, Washington
}

Prepared for

U.S. Department of Energy

Richland, Washington 
WHC-SD-WM-TI-768

Revision 0

This page intentionally left blank. 
WHC-SD-WM-TI-768

Revision 0

EXECUTIVE SUMMARY

ES1.0 INTRODUCTION

This document examines the high-level waste (HLW) volume and composition sensitivities to a range of process retrieval and glass formulation options. The planned process for $H L W$ delivery to the Phase I plants is to provide.separate water washed feeds from tanks 241-AZ-101, 241-AZ-102, and 241-AY-102 (Bacon 1996). Tank 241-AY-102 will contain a mixture of tank $241-C-106$ and 241-AY-102 wastes. For glass formulation purposes, various blends were also considered, including a nominal blend of these wastes consisting of 80 percent of Tank 241-AZ-101, 80 percent of Tank 241-AZ-102, 37 percent of Tank 241-C-105, and 15 percent Tank 241-AY-102 sludges. Feed composition estimates were primarily derived from the analysis of core samples and water washing tests performed on these samples. Glass models and data from laboratory glass studies were used to estimate the achievable waste oxide loading and corresponding glass volume for various Phase I feeds. This study also takes into consideration possible variations in feed composition due to uncertainties in the waste composition, blending, or pretreatment processes that will be applied to these wastes.

Glasses have been formulated for a range of anticipated Phase I wastes using estimates of their property data based on property models. This includes glass property data correlations developed by Pacific Northwest National Laboratory that have been incorporated into computer codes (models) to facilitate calculation of estimated glass properties. These models were extensively used in the current evaluation.

Key issues related to feed processability, feed composition uncertainty, and immobilization process technology are identified for future consideration in other tank waste disposal program activities. 


\section{WHC-SD-WM-TI-768}

Revision 0

\section{ES2.0 GLASS DATA}

Based on current models, iron and aluminum are the main components that control the volume and composition of the Phase I HLW glasses. Liquidus temperature and precipitation of nepheline $\left(\mathrm{NaAlSi}_{2} \mathrm{O}_{\phi}\right)$ in the canister glass are the limiting properties of interest for most of these glasses. Liquidus temperature is important because this is the temperature where crystals may precipitate from the glass and clog the pour. spout.or possibly short.the melter electrodes (i.e., if the sludge phases are electrically conductive). Precipitation of nepheline during cooling of the glass filled canisters is important because this is likely to produce an unacceptable waste glass due to a substantial decrease in durability and a diminished amount of aluminum in the remaining glass phase. Some data were found to be lacking with respect to the glass composition region of interest for the Phase I HLW feeds. Pacific Northwest National Laboratory provided glass formulation support by experimentaly evaluating properties of glasses in this composition region. Unpublished glass property data were also obtained from Westinghouse Savannah River Company. These data were used to developed improved data correlations and calculational models for the Phase I wastes. Glass work produced significant results in the following areas:

- Significant component interaction effects were noted in several Phase I glasses. The most important interaction is the effect of aluminum on the solubility of iron (i.e., reducing aluminum increases the solubility of iron). Aluminum and iron have a dominant effect on the liquidus temperature of the Phase I HLW glasses, while aluminum, silica, and sodium control the nepheline precipitation behavior of these glasses.

- New liquidus temperature models were developed from the current database and they are to be validated with a new set of glasses with targeted variations in $\mathrm{Al}_{2} \mathrm{O}_{3}, \mathrm{~B}_{2} \mathrm{O}_{3}, \mathrm{Cr}_{2} \mathrm{O}_{3}, \mathrm{Fe}_{2} \mathrm{O}_{3}, \mathrm{Li}_{2} \mathrm{O}, \mathrm{MgO}, \mathrm{MnO}, \mathrm{Na}_{2} \mathrm{O}$, and $\mathrm{SiO}_{2}$ to measure the effect of each component on the liquidus temperature of spinel. Spinel structures 
WHC-SD-WM-TI-768

Revision 0

are represented by the formula $M^{I I} M^{I I I}{ }_{2} O_{4}$, where $M^{I I}$ consists of di-valent Fe, $\mathrm{Mg}$, or $\mathrm{Mn}$ and $\mathrm{M}^{\mathrm{III}}$ tri-valent $\mathrm{Fe}, \mathrm{Cr}$, or $\mathrm{Al}$.

- Precipitation of nepheline appears to be a significant issue for certain feeds. Significant progress was made in fiscal year 1996 in determining the composition ranges where nepheline precipitation could be a problem and estimating the possible durability effects of nepheline precipitation.

- Glass property models may be used to formulate and estimate the volume of HLW glasses. Based on these models and glass property data, the maximum waste loading for the Phase I glasses varies from 29.3 to $30.7 \mathrm{wt} \%$ on an adjusted feed oxide basis. The adjusted feed oxide basis is defined as the weight of total nonvolatile feed oxides excluding sodium and silica on an oxide basis divided by weight of the product glass. This indicates there is a 17 percent contingency or operating margin between the maximum theoretical waste loading and the minimum 25 percent adjusted feed oxide basis specified in the Request for Proposal. The 25 percent adjusted feed oxide appears to be a conservative and achievable value for Phase $I$.

The primary conclusions from these findings are as follows:

- There is an incentive to reduce the amount of aluminum in the Phase I waste with caustic washing.

- The iron solubility limit in the HLW glass may be reduced significantly by high aluminum concentration due to liquidus temperature constraints. High concentrations of chromium and manganese also have an adverse effect on allowable iron compositions because of liquidus temperature effects. 


\section{WHC-SD-WM-TI-768}

\section{Revision 0}

- The nepheline region can be avoided by defining a minimum limit for $\mathrm{SiO}_{2}$ such that glasses with a normalized $\mathrm{SiO}_{2}$ content $\geq 0.62$ (based on the sum of $\mathrm{SiO}_{2}+\mathrm{Na}_{2} \mathrm{O}+\mathrm{Al}_{2} \mathrm{O}_{3}$ ) should not be susceptible to nepheline precipitation in the canister. The defined limit for nepheline is important for certain wastes, such as Tank 241-C-106 waste, where the waste oxide loading limits are likely to be determined by the nepheline forming characteristics of the glass.

- Glass property data and related models should be considered in developing future baseline glass quantity estimates. Recent glass data identify some important component interaction effects that are not well represented in simplified single component and multi-component constraint limits. A primary example is the effect of aluminum on iron solubility in glass. This interaction generally results in a larger volume of glass and more incentive for caustic washing as compared to glass estimates derived from single component or multi-component limits.

\section{ES3.0 GLASS VOLUME AND WASTE OXIDE LOADING ESTIMATES}

In this study, several different Phase I staging (retrieval, blending, and pretreatment) scenarios were used to generate example feed compositions for glass formulations, testing, and glass sensitivity analysis. It should be recognized that these scenarios will not necessarily match the final process that is selected for Phase I. Several glasses were formulated for each waste based on glass property models to establish the range of possible waste oxide loading for the wastes identified in the Phase I Request for Proposal. 


\section{Revision 0}

The glass models and glass property results were used to produce the estimates in Table ES-1 for the water washed (base case) and caustic washed Phase I wastes (Tanks 241AZ-101, 241-AZ-102, and 241-C-106 wastes and various blends of these wastes). The glass models include the Fulcher first-order viscosity model (Section 5.3), spinel second-order liquidus temperature model (Section 5.5), second-order product consistency test $\mathrm{B}$ and $\mathrm{Na}$ release models and the nepheline model (Section 5.6).

Table ES-1. Glass Volume Estimates for Unblended Phase I Wastes.

\begin{tabular}{|c|c|c|c|c|c|c|c|}
\hline Phase I tanks & $\begin{array}{l}\text { Water } \\
\text { washed } \\
\text { waste }\end{array}$ & $\begin{array}{c}\text { Waste } \\
\text { inventory } \\
(M T)\end{array}$ & $\begin{array}{l}\text { Base } \\
\text { glass } \\
\text { WOL, } \\
\text { wt \% }\end{array}$ & $\begin{array}{c}\text { Base } \\
\text { glass } \\
A F O \\
w t \%\end{array}$ & $\begin{array}{c}\text { Cans of } \\
\text { base } \\
\text { glass } \\
\text { (limit) }\end{array}$ & $\begin{array}{c}\text { Cans } \\
w / 50 \% \\
\mathrm{Al}_{2} \mathrm{O}_{3} \\
\text { removed } \\
\text { (limit) }\end{array}$ & $\begin{array}{c}\text { Cans } \\
w / 75 \% \\
\mathrm{Al}_{2} \mathrm{O}_{3} \\
\text { removed } \\
\text { (limit) } \\
\end{array}$ \\
\hline $241-A Z-101$ & $241-A Z-101$ & 109.46 & 36.08 & 30.26 & $183\left(T_{\nu}\right)$ & $154\left(T_{L}\right)$ & $145\left(T_{L}\right)$ \\
\hline $241-A Z-102$ & $241-A Z-102$ & 172.99 & 34.40 & 29.28 & $305\left(T_{\nu}\right)$ & $265\left(T_{L}\right)$ & $268\left(T_{L}\right)$ \\
\hline $241-C-106$ & $241-C-106 A$ & 485.52 & 67.45 & 30.65 & $\begin{array}{c}436 \\
\text { (neph.) }\end{array}$ & $\begin{array}{c}356 \\
\left(T_{L} / \text { neph }\right)\end{array}$ & $\begin{array}{c}316 \\
\text { (low vis) }\end{array}$ \\
\hline Total & & 767.97 & & & 924 & 775 & 729 \\
\hline
\end{tabular}

$A F O=$ Adjusted feed oxide

$W O L=$ Waste oxide loading

${ }^{a}$ Water washed waste oxide inventory assuming $100 \%$ retrieval efficiency.

${ }^{b}$ Defense Waste Processing Facility canisters of glass limited by $T_{L}$ liquidus temperature or nepheline.

If caustic washing processes are employed, the glass models predict that 80 canisters could be saved by removing 50 percent of the $\mathrm{Al}_{2} \mathrm{O}_{3}$ from Tank 24I-C-106 waste and 120 canisters if 75 percent of the $\mathrm{Al}_{2} \mathrm{O}_{3}$ is removed from this waste. Caustic washing processes appear to be less desirable for Tanks 24I-AZ-101 and 241-AZ-102 wastes, producing 29 and 40 fewer canisters, respectively. These estimates are based on the physical and chemical properties of the glass. Caustic washing studies will be necessary to determine whether it is possible to remove this much aluminum from the Phase I wastes. Also, it is unclear whether the Tank Waste Remediation System safety basis could be modified in time to allow enough tank space for a caustic washing option for these wastes. 
WHC-SD-WM-TI-768

Revision 0

Table ES-2. Phase I Blend Compositions.

\begin{tabular}{|l|l|}
\hline Nominal Blend: & $\begin{array}{l}0.8 * 241-A Z-101+0.8 * 241-A Z-102+0.37 * 241-C-106+0.15 * \\
241-A Y-102\end{array}$ \\
\hline AZ Blend: & $241-A Z-101+241-A Z-102$ \\
\hline AYC Blend: & $241-C-106+241-A Y-102$ \\
\hline AYC-A Blend: & $241-A Y-102+0.1625 * 241-C-106$ \\
\hline AYC-B Blend: & $241-A Y-102+0.4875 * 241-C-106$ \\
\hline AZC-A Blend: & AZ Blend $+0.4875 * 241-C-106$ \\
\hline AZC-B Blend: & AZ Blend $+0.1625 * 241-C-106$ \\
\hline
\end{tabular}

Glass property data indicate the maximum waste oxide loading for the nominal blend feed (Table ES-2) is $48.5 \mathrm{wt} \%$ total oxides or $30.9 \mathrm{wt} \%$ on an adjusted feed oxide basis. If the Phase I wastes are processed separately, the average waste oxide loading is $30.1 \mathrm{wt} \%$ adjusted feed oxide (mass weighted average basis, Table ES-1). This indicates that only a small benefit will be gained from blending in terms of reducing the overall volume of glass. There may be other benefits from blending, including reducing the concentration of problem components such as silver and reducing the number of glasses and process conditions that need to be qualified as part of product acceptance.

The current estimates of waste glass volume do not include any allowance for operating margin contingency (i.e., to compensate for process fluctuations and uncertainties in the waste or glass composition analysis and glass property models). If it is assumed that production glasses are formulated to 85 percent of the maximum waste loading, the estimate waste loadings for the tank-by-tank and nominal blend feed are 25.6 and 26.3 percent adjusted feed oxide, respectively. For the tank-by-tank feed, this results in $957,000 \mathrm{~kg}$ of glass (i.e., 580 defense waste processing facility canisters) for the minimum Phase I feed of $245,000 \mathrm{~kg}$ adjusted feed oxide or 1,816,000 kg of glass (i.e., 1,100 defense waste processing facility canisters) for the maximum feed of $465,000 \mathrm{~kg}$ adjusted feed oxide. 
WHC-SD-WM-TI-768

Revision 0

\section{ES4.0 NOBLE METALS}

Noble metal oxides and alloys of silver, palladium, tellurium, rhodium, and $\mathrm{RuO}_{2}$ are virtually insoluble in borosilicate glass. The Phase I water washed nominal blend contains 0.38 wt \% noble metals $\left(\mathrm{Ag}_{2} \mathrm{O}, \mathrm{RuO}_{2}, \mathrm{TeO}_{2}, \mathrm{PdO}\right.$, and $\left.\mathrm{Rh}_{2} \mathrm{O}_{3}\right)$. At 48 percent waste oxide loading in the glass, the noble metals concentration would be $0.182 \mathrm{wt} \%$. If the Phase I feeds are processed separately, Tanks 241-AZ-101, 241-AZ-102, and 241-C=106 glasses should nominally contain $0.17,0.11$, and 0.24 percent noble metals, respectively. Recent grab samples from Tank 241-C-106 indicate the bounding noble metals concentration could be as high as $0.52 \mathrm{wt} \%$ in glass because of the amount of silver and ruthenium in this waste. This noble metals concentration is likely to cause premature failure of the melter electrodes and bottom refractory (based on the low melting temperature of silver $\left[960{ }^{\circ} \mathrm{C}\right]$ and laboratory-scale tests in the Research-Scale Melter performed with feeds containing 0.33 to $0.46 \mathrm{wt} \%$ noble metals). An added concer is the high silver inventory in Tank 241-AY-102, with $1.85 \mathrm{wt} \%$ silver oxide $\left(\mathrm{Ag}_{2} \mathrm{O}\right)$ in the waste. If the noble metals concentration is determined to be too high, other wastes should be considered as potential blend stock for mitigating the high silver and ruthenium inventories in Tanks 241-C-106 and 241-AY-102. This issue mostly affects the performance of joule-heated melters, although noble metal deposits have also plugged the bottom drains of various induction-heated melters.

\section{ES5.0 SENSITIVITY ANALYSIS}

Sensitivity analyses were performed to evaluate the effects of feed composition and more aggressive caustic washing processes for the Phase I wastes. The purposes of this analysis are to provide information to the pretreatment and waste retrieval functions and to identify high priority issues to be addressed in any future waste characterization activities.

The most important $\mathrm{HLW}$ components from a glass making perspective are $\mathrm{Al}_{2} \mathrm{O}_{3}$ and $\mathrm{Fe}_{2} \mathrm{O}_{3}$. Because glass volume predictions are important to overall project cost, a sensitivity 


\section{WHC-SD-WM-TI-768}

\section{Revision 0}

study was performed to assess the likely impact of varying the amount of $\mathrm{Al}_{2} \mathrm{O}_{3}$ and $\mathrm{Fe}_{2} \mathrm{O}_{3}$ in the Tanks 24I-AZ-101 and 24I-C-106 wastes. For Tank 24I-AZ-10I waste, the $\mathrm{Al}_{2} \mathrm{O}_{3}$ to $\mathrm{Fe}_{2} \mathrm{O}_{3}$ ratio of 0.74 is an important characteristic of the glass. If this ratio is less than 0.74 , the glass volume is controlled by the liquidus temperature characteristics of the glass, while the nepheline forming properties control the volume of glass above this value.

If the mass of all components except $\mathrm{Al}_{2} \mathrm{O}_{3}$ or $\mathrm{Fe}_{2} \mathrm{O}_{3}$ is held constant, the volume of glass from processing Tank 241-AZ-101 waste is projected to increase 4.3 and 5.6 percent, respectively, per 10 percent increase in the amount of $\mathrm{Fe}_{2} \mathrm{O}_{3}$ or $\mathrm{Al}_{2} \mathrm{O}_{3}$. The total glass volume would decrease 0.65 and 2.8 percent, respectively, with a decrease of 10 percent in the amount of $\mathrm{Fe}_{2} \mathrm{O}_{3}$ or $\mathrm{Al}_{2} \mathrm{O}_{3}$ in this waste. Similar trends were also identified for Tank 24I-C-106 waste, with an increase of 4.3 and 4.7 percent in glass volume per 10 percent increase in $\mathrm{Fe}_{2} \mathrm{O}_{3}$ or $\mathrm{Al}_{2} \mathrm{O}_{3}$, respectively, and a decrease of 1.1 and 3.6 percent with a 10 percent decrease in the amount of $\mathrm{Fe}_{2} \mathrm{O}_{3}$ or $\mathrm{Al}_{2} \mathrm{O}_{3}$ in this tank. These figures can be used to determine the impact of over-estimating or under-estimating the mass of these components (based on a repository disposal fee of $\$ 356,000$ per canister). These results reflect the effect of reducing the quantity of $\mathrm{Al}_{2} \mathrm{O}_{3}$ in the waste by caustic washing or inadvertently adding $\mathrm{Al}_{2} \mathrm{O}_{3}$ by precipitation from the liquid phase.

\section{ES6.0 PROCESS TECHNOLOGY}

Additional information has recently become available on performance of the hightemperature melter and high-temperature glasses. Tests with a refractory-lined hightemperature melter indicate that the melt-rate capacity $\left(a t, 1,350^{\circ} \mathrm{C}\right)$ is only about 10 percent higher than the capacity of the low-temperature melter (at $1,150^{\circ} \mathrm{C}$ ). Dissolution of melter refractory components into glass increases aluminum and chromium and thus reduces the previously expected waste oxide loading advantage of the high-temperature melter (if corrosion product components are included in calculating the liquidus temperature limits for glass formulation). Glass formulation studies have also shown that the solubility of 


\section{WHC-SD-WM-TI-768}

Revision 0

chromium oxide (as one of several spinel-forming components) is only slightly affected by the temperature and composition of borosilicate and aluminum silicate glasses (thus reducing the potential advantage of the high-temperature melter). Rapid corrosion of the melter electrode materials at high-temperature $\left(T>1,450^{\circ} \mathrm{C}\right)$ also indicates that development of a hightemperature melter is likely to be more expensive than originally anticipated due to the need to identify and test more exotic (and expensive) electrode materials. For the Phase I program, the private vendors may elect to use other melters, such as the high-temperature cold crucible melter, that may not be susceptible to refractory corrosion and potential sludge accumulation problems discussed in this report.

Glass property data indicate that precipitation of sludge forming solids (spinel) limits the achievable waste oxide loading for sludges from Tanks 241-AZ-101/241-AZ-102. If a practical sludge removal system was developed for the low-temperature melter, it might be feasible to process glasses that contain a small fraction of undissolved solids (i.e., precipitated crystals). Glass formulation results indicate the waste oxide loading of pretreated sludges from Tanks 241-AZ-101/241-AZ-102 could be increased by 30 to 40 percent if the solids precipitation limits (liquidus temperature constraints) were relaxed. With this feature, glasses could be formulated beyond the liquidus temperature limit for the lowtemperature melter to possibly match the waste loading capabilities of the high-temperature melter, thus reducing the predicted life-cycle costs for the low-temperature melter. If the liquidus temperature limit is raised from 1,050 to 1,100 ${ }^{\circ} \mathrm{C}$, approximately 53 fewer canisters (10.7 percent less glass) should be produced from the nominal blend feed.

Glass formulation models indicate that only two components $\left(\mathrm{Fe}_{2} \mathrm{O}_{3}\right.$ and $\left.\mathrm{Al}_{2} \mathrm{O}_{3}\right)$ need to be known with reasonable precision (to within 15 percent or their true values) to estimate the amount of glass likely to be produced from Tank 24I-AZ-10I waste, and four components ( $\mathrm{SiO}_{2}, \mathrm{Na}_{2} \mathrm{O}, \mathrm{Fe}_{2} \mathrm{O}_{3}$, and $\mathrm{Al}_{2} \mathrm{O}_{3}$ ) to estimate the volume of glass from Tank 241-C-106 waste. Other components, from a glass formulation perspective, that need to be known (to within 100 percent of their true values) are $\mathrm{Na}_{2} \mathrm{O}, \mathrm{MnO}$, and $\mathrm{ZrO}_{2}$ for Tank 241-AZ-101 waste and $\mathrm{Cr}_{2} \mathrm{O}_{3}, \mathrm{MnO}$, and $\mathrm{CaO}$ for Tank 241-C-106 waste. While it may be desirable to obtain as 
WHC-SD-WM-TI-768

Revision 0

much information as possible, the volume and composition of most glasses can be reasonably determined from $\mathrm{Fe}_{2} \mathrm{O}_{3}$ and $\mathrm{Al}_{2} \mathrm{O}_{3}$ composition data, together with some knowledge of $\mathrm{Cr}_{2} \mathrm{O}_{3}$, $\mathrm{MnO}$, noble metals $\left(\mathrm{Ag}_{2} \mathrm{O}, \mathrm{PdO}, \mathrm{Rh}_{2} \mathrm{O}_{3}\right.$, and $\left.\mathrm{Ru}_{2} \mathrm{O}_{3}\right)$, and semi-soluble waste components $\left(\mathrm{P}_{2} \mathrm{O}_{5}\right.$ and $\left.\mathrm{SO}_{4}\right)$.

This report also discusses the performance characteristics of the low-and hightemperature melters, and radioactive test melters and test facilities at the Hanford Site. Similar information is provided on the glass property constraints (i.e., certain waste form qualification requirements, viscosity, electrical conductivity, liquidus temperature, and durability) and on the glass solubility constraints for minor components $(\mathrm{Cr}, \mathrm{P}, \mathrm{Cl}, \mathrm{F}, \mathrm{S}, \mathrm{Bi}$, $U$, noble metals, and Ti). Balance of plant issues are also discussed, including the possible effects of $\mathrm{Hg}, \mathrm{Cd}, \mathrm{Cl}, \mathrm{F}, \mathrm{SO}_{4}, \mathrm{NO}_{x}$, and criticality control. 


\section{WHC-SD-WM-TI-768}

Revision 0

CONTENTS

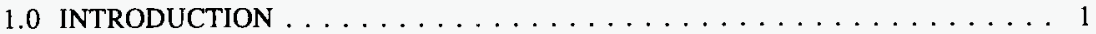

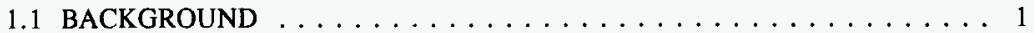

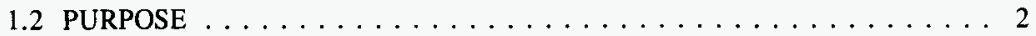

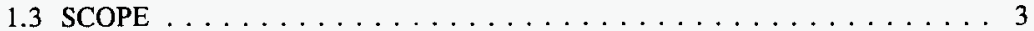

2.0 PHASE I HIGH-LEVEL WASTES $\ldots \ldots \ldots \ldots \ldots \ldots \ldots \ldots \ldots$

2.1 SELECTION OF PHASE I WASTES $\ldots \ldots \ldots \ldots \ldots \ldots \ldots \ldots$

2.2 SOURCE OF WASTES $\ldots \ldots \ldots \ldots \ldots \ldots \ldots \ldots \ldots \ldots \ldots \ldots$

2.3 GENERAL CHARACTERISTICS OF WASTES $\ldots \ldots \ldots \ldots \ldots$

3.0 CURRENT ESTIMATES OF MELTER FEED COMPOSITION $\ldots \ldots \ldots \ldots \ldots 11$

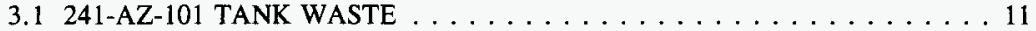

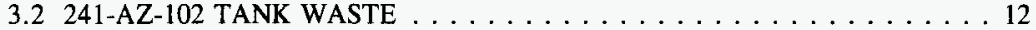

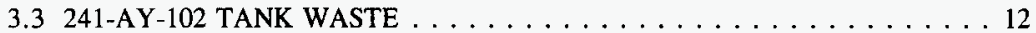

3.4 241-C-106 TANK WASTE . . . . . . . . . . . . . . 12

3.5 NOMINAL BLEND COMPOSITION $\ldots \ldots \ldots \ldots$

4.0 VITRIFICATION . . . . . . . . . . . . . . . . . . . . . 23

4.1 IMPACT OF VITRIFICATION TECHNOLOGY ON FEED

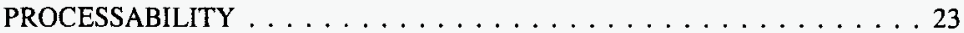

4.2 STATUS OF VITRIFICATION TECHNOLOGY $\ldots \ldots \ldots \ldots \ldots \ldots$

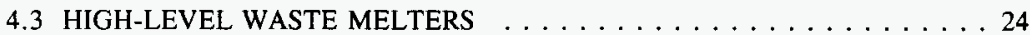

4.3.1 Low-Temperature, Joule-Heated Melter . . . . . . . . . . 24

4.3.2 High-Temperature, Joule-heated Melter . . . . . . . . . . . . . 33

4.3.3 Radioactive Melter Tests . . . . . . . . . . . . . . . . . 44

5.0 FEED PROCESSABILITY . . . . . . . . . . . . . . . . . . . 49

5.1 WASTE FORM/WASTE FORM QUALIFICATION . . . . . . . . . . . . 49

5.2 GLASS PROPERTY CONSTRAINTS/MELTER FEED COMPOSITION

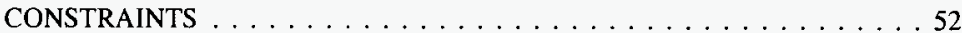

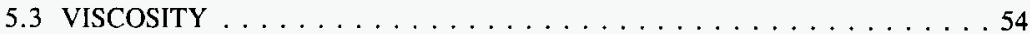

5.4 ELECTRICAL CONDUCTIVITY $\ldots \ldots \ldots \ldots \ldots \ldots \ldots \ldots \ldots \ldots \ldots$

5.5 LIQUIDUS TEMPERATURE $\ldots \ldots \ldots \ldots \ldots \ldots \ldots \ldots \ldots \ldots \ldots \ldots$

5.6 DURABILITY . . . . . . . . . . . . . . . . . 67

5.7 GLASS SOLUBILITY CONSTRAINTS $\ldots \ldots \ldots \ldots \ldots \ldots \ldots$

5.7 .1 Chromium Oxide Solubility . . . . . . . . . . . . . 76

5.7 .2 Phosphorus Solubility . . . . . . . . . . . . . . . 79

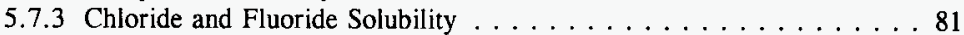

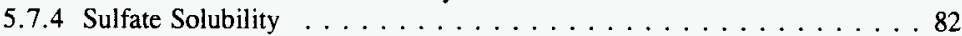

5.7 .5 Bismuth and Uranium Solubility $\ldots \ldots \ldots \ldots \ldots \ldots$

5.7 .6 Noble Metals Solubility . . . . . . . . . . . . . . 84

5.7 .7 Titanium Solubility . . . . . . . . . . . . . . . . . . . 87

5.7 .8 Minor Component Solubility Limits . . . . . . . . . . . . 88 
WHC-SD-WM-TI-768

Revision 0

5.8 COMPARISON OF SIMULANTS TO RADIOACTIVE PHASE I WASTES . 89

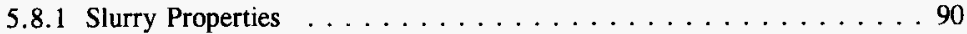

5.8 .2 Glass Properties . . . . . . . . . . . . . . 91

6.0 PROCESSABILITY ASSESSMENT FOR PHASE I FEEDS . . . . . . . . . 95

6.1 WASTE COMPOSITIONS FOR GLASS FORMULATION

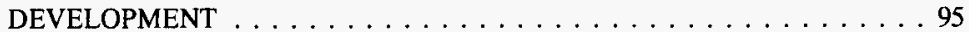

6.2 GLASS FORMULATION . . . . . . . . . . . . . . 98

6.2.1 Glass Formulation Development for the Water Washed Nominal

Blend ............................ . 104

6.2.2 Glass Formulation Development for the Caustic Washed Nominal

Blend . . . . . . . . . . . . . . . . . . . 107

6.2.3 Glass Formulation development for the Water Washed AZ Blend . . . 108

6.2.4 Glass Formulation Development for the Water Washed 241-C-106A

Tank Waste . . . . . . . . . . . . . . . . . . . . . 109

6.2.5 Glass Formulation Development for the Water Washed 241-C-106B

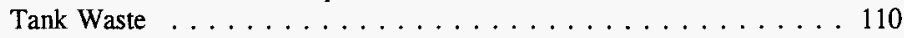

6.3 GLASS VOLUME PREDICTIONS . . . . . . . . . . . . . . . . 111

6.3.1 Bounding Composition Limits for the (Water Washed) Nominal Blend

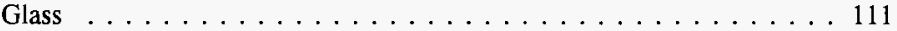

6.3.2 Bounding Composition Limits for the (Caustic Washed) Nominal

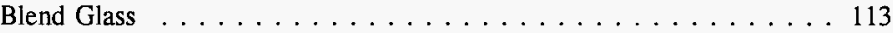

6.3.3 Bounding Composition Limits for the AZ Blend Glass . . . . . . 115

6.3.4 Bounding Composition Limits for the 241-C-106A Glass . . . . . 117

6.3.5 Bounding Composition Limits for the 241-C-106B Glass . . . . . 119

6.3.6 Summary of Results for Phase I Experimental Glasses . . . . . . 120

6.3.7 Glass Volume Estimates for Phase I Wastes . . . . . . . . . . 123

6.3.8 Bounding Effects of $\mathrm{Al}_{2} \mathrm{O}_{3}$ and $\mathrm{Fe}_{2} \mathrm{O}_{3}$ in Glass $\ldots \ldots \ldots \ldots \ldots 125$

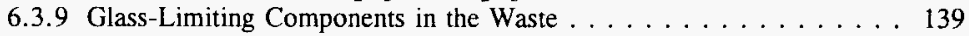

6.4 BALANCE OF PROCESS . . . . . . . . . . . . . . . . 143

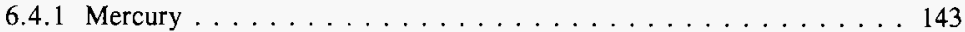

6.4 .2 Cadmium . . . . . . . . . . . . . . . . . . . . 144

6.4.3 Chloride, Fluoride, and Sulfate . . . . . . . . . . . 145

6.4 .4 Nitrogen Oxides . . . . . . . . . . . . . . . . 147

6.4 .5 Criticality Control . . . . . . . . . . . . . . . . . . 148

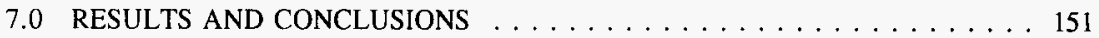

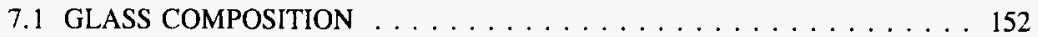

7.2 MELTER PERFORMANCE SENSITIVITIES . . . . . . . . . . . 152

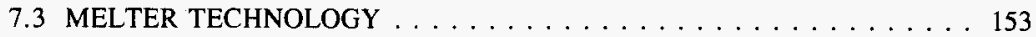

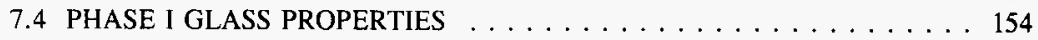

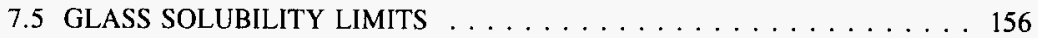

7.6 WASTE OXIDE LOADING AND GLASS VOLUME ESTIMATES . . . . 157

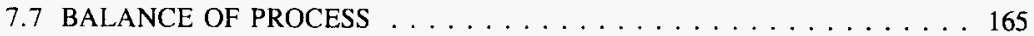


WHC-SD-WM-TI-768

Revision 0

8.0 REFERENCES .

\section{LIST OF FIGURES}

2-1. Composition of the Principal Streams from the Uranium Recovery Process. . . . . 8

2-2. Composition of the Principal Streams from PUREX and B Plant Processes. . . . . 9

5-1. Predicted Versus Measured Liquidus Temperature of $\mathrm{Zr}$-Containing Crystals

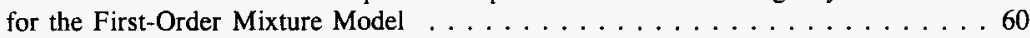

5-2. Predicted Versus Measured Liquidus Temperature of Spinel Phases in Composition Variability Study Glasses Based on First-Order Mixture Model . . . 61

5-3. Comparison of Normalized Boron Release From Quenched and Canister Centerline Cooled Glass.

5-4. $\mathrm{Na}_{2} \mathrm{O}-\mathrm{Al}_{2} \mathrm{O}_{3}-\mathrm{SiO}_{2}$ Phase Diagram $\ldots \ldots \ldots \ldots \ldots \ldots \ldots \ldots \ldots \ldots$

5-5. Nepheline Region in $\mathrm{Na}_{2} \mathrm{O}-\mathrm{Al}_{2} \mathrm{O}_{3}-\mathrm{SiO}_{2}$ Phase Diagram $\ldots \ldots \ldots \ldots$

5-6. Effect of Neutralized Current Acid Waste Loading on 7-Day Product Consistency Test Normalized Element Sodium and Silicon Releases . . . . . . . . . . . . 74

5-7. Effect of Aluminum Oxide on Normalized Boron Release from Composition Variability Study and HW39-4 Glasses . . . . . . . . . . . . . . . . 75

6-1. Effect of Liquidus Temperature, Nepheline, and Composition Variability Study Limits on Volume of Glass versus $\mathrm{Al}_{2} \mathrm{O}_{3}$ in Tank 241-AZ-101 Waste . . . . 128

6-2. Effect of High-Level Waste Glass Model and Composition Variability Study Limits on Volume of Glass versus $\mathrm{Al}_{2} \mathrm{O}_{3}$ in Tank 241-AZ-101 Waste . . . . 128

6-3. $\mathrm{Al}_{2} \mathrm{O}_{3}$ and $\mathrm{Fe}_{2} \mathrm{O}_{3}$ Concentrations in Glass versus $\mathrm{Al}_{2} \mathrm{O}_{3}$ in Tank $241-\mathrm{AZ}-101 \ldots 129$

6-4. Change in Volume of Glass versus Percent Change of $\mathrm{Al}_{2} \mathrm{O}_{3}$ in Tank 241-AZ-101 Waste . . . . . . . . . . . . . . . . . . . . . . . . . . 129

6-5. Effect of Liquidus Temperature, Nepheline, and Composition Variability Study Limits on Volume of Glass versus $\mathrm{Fe}_{2} \mathrm{O}_{3}$ in Tank 241-AZ-101 Waste . . . 130

6-6. Effect of High-Level Waste Glass Model and Composition Variability Study Limits on Volume of Glass versus $\mathrm{Fe}_{2} \mathrm{O}_{3}$ in Tank 241-AZ-101 Waste 
WHC-SD-WM-TI-768

Revision 0

\section{LIST OF FIGURES (CONTINUED)}

6-7. $\mathrm{Fe}_{2} \mathrm{O}_{3}$ and $\mathrm{Al}_{2} \mathrm{O}_{3}$ Concentrations in Glass versus $\mathrm{Fe}_{2} \mathrm{O}_{3}$ in

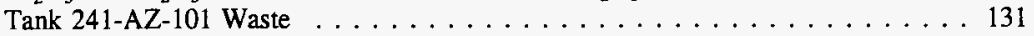

6-8. Change in Volume of Glass versus Percent Change of $\mathrm{Fe}_{2} \mathrm{O}_{3}$

in Tank 241-AZ-101 Waste . . . . . . . . . . . . . . . . . . . 131

6-9. Effect of Liquidus Temperature, Nepheline, and Composition Variability

Study Limits on Volume of Glass versus $\mathrm{Al}_{2} \mathrm{O}_{3}$ in Tank 241-C-106 Waste . . . 135

6-10. Effect of High-Level Waste Glass Model and Composition Variability Study Limits on Volume of Glass versus $\mathrm{Al}_{2} \mathrm{O}_{3}$ in Tank 241-C-106 Waste $\ldots \ldots \ldots 135$

6-11. $\mathrm{Al}_{2} \mathrm{O}_{3}$ and $\mathrm{Fe}_{2} \mathrm{O}_{3}$ Concentrations in Glass versus $\mathrm{Al}_{2} \mathrm{O}_{3}$

in Tank 241-C-106 Waste . . . . . . . . . . . . . . . . . 136

6-12. Change in Volume of Glass versus Percent Change of $\mathrm{Al}_{2} \mathrm{O}_{3}$ in Tank 241-C-106 Waste . . . . . . . . . . . . . . . . . . 136

6-13. Effect of Liquidus Temperature, Nepheline, and Composition Variability Study Limits on Volume of Glass versus $\mathrm{Fe}_{2} \mathrm{O}_{3}$ in Tank 241-C-106 Waste $\ldots \ldots \ldots 137$

6-14. Effect of High-Level Waste Glass Model and Composition Variability Study Limits on Volume of Glass versus $\mathrm{Fe}_{2} \mathrm{O}_{3}$ in Tank 241-C-106 Waste

6-15. $\mathrm{Fe}_{2} \mathrm{O}_{3}$ and $\mathrm{Al}_{2} \mathrm{O}_{3}$ Concentrations in Glass versus $\mathrm{Fe}_{2} \mathrm{O}_{3}$

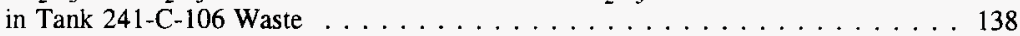

6-16. Change in Volume of Glass versus Percent Change

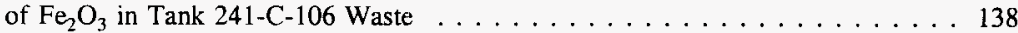

\section{LIST OF TABLES}

3-1. Tank 241-AZ-101 Waste Composition . . . . . . . . . . . . . . 13

3-2. Tank 241-AZ-102 Waste Composition. . . . . . . . . . . . . . . . . . . . 14

3-3. Tank 241-AY-102 Waste Composition . . . . . . . . . . . . . 16

3-4. Tank 241-C-106 Waste Composition. . . . . . . . . . . . . . . . . . . . 18 
WHC-SD-WM-TI-768

Revision 0

\section{LIST OF TABLES (CONTINUED)}

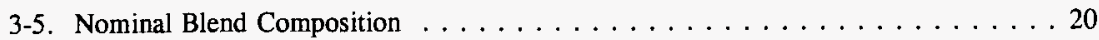

4-1. Liquid-Fed Ceramic Melter Decontamination Factors . . . . . . . . . . 30

4-2. Corrosion Rates for Candidate Electrode Materials in

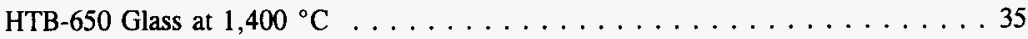

4-3. Glass Production Rates for the Small-Scale High-Temperature Melter . . . . . . . 38

4-4. Glass Production Rates for Low Temperature Melters . . . . . . . . . . . . 39

4-5. Melter Decontamination Factors for High-Temperature and Low-Temperature

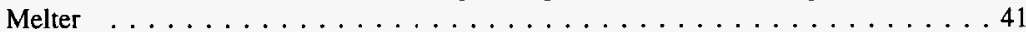

4-6. Percent of Feed Components Volatilized During Low-Level Waste Melter Tests . . . . . . . . . . . . . . . . . . . 43

4-7. Composition and Volume Percent Crystals in Small-Scale High Temperature Melter Tests 1 and $2 \ldots \ldots \ldots \ldots \ldots \ldots$

4-8. Principal Radionuclides in Savannah River's Waste . . . . . . . . . . . 45

5-1. Waste Acceptance Preliminary Specifications for the Defense Waste Processing Facility High-Level Waste Form $\ldots \ldots \ldots \ldots \ldots \ldots \ldots \ldots \ldots \ldots \ldots$

5-2. Hanford Waste Vitrification Plant Glass Property Constraints $\ldots \ldots \ldots \ldots 2$

5-3. Glass Composition Range Covered By Composition Variability Study (CVS-1 and CVS-2) Composition Region . . . . . . . . . . . . . . . . 53

5-4. Fulcher First-Order Viscosity Model Coefficients A, B and $T_{i} \ldots \ldots \ldots 5$

5-5. Arrhenius Equation Electrical Conductivity Coefficients A and B . . . . . . 57

5-6. Component Coefficients for First-Order Model of Liquidus Temperature . . . . . 59

5-7. First and Second-Order Spinel Liquidus Temperature Model Coefficients B, C and D . . . . . . . . . . . . . . . . 65

5-8. Comparison of Measured to Predicted Spinel Liquidus Temperatures for Phase I Glasses and Selected Group of CVS and Savannah River Glasses . . . . . . . . . . 66 
WHC-SD-WM-TI-768

Revision 0

\section{LIST OF TABLES (CONTINUED)}

5-9. Environmental Assessment Glass Dissolution Rates . . . . . . . . . . . 68

5-10. Coefficients for Second-Order Model (\#3) of Natural Logarithm of

Average 7-Day Product Consistency Test Normalized Elemental Releases . . . . . 77

5-11. Chloride and Fluoride Glass Compositions and Percent

Retained During Pilot-Scale Ceramic Melter-22 and

Pilot-Scale Ceramic Melter-23 Melter Tests . . . . . . . . . . . . . . 82

5-12. Noble Metals Feed Composition and Percent Retained in the PAMELA Melter . 85

5-13. Noble Metals Feed Composition and Percent Retained in the Savannah River Site

Test Melter . . . . . . . . . . . . . . . . . . . . 86

5-14. Noble Metals Feed Composition, Percent Retained, and Average Glass

Composition in Large-Scale Japanese Melter Tests . . . . . . . . . . . . . . . 87

5-15. Minor Component Glass Solubility Limits for High-Level Waste . . . . . . . . 89

5-16. Comparison of Radioactive Sample and Simulant Rheology Properties . . . . . . 91

5-17. Durability Results for $241-\mathrm{AZ}-101$, Core 1 Glass $\ldots \ldots \ldots \ldots 2$

5-18. Durability Results for 241-AZ-101, Core 2 Glass $\ldots \ldots \ldots \ldots 2$

5-19. Durability Results for $241-\mathrm{AZ}-102$, Core 1 Glass $\ldots \ldots \ldots \ldots$. . . . . 92

6-1. Waste and Blend Compositions in Mass Fractions on Nonvolatile Oxide Basis . . . 97

6-2. Waste Loadings, Glass Compositions, Glass Property Predictions, and Additive Composition: Nominal Blend Waste . . . . . . . . . . . . . . . . . . . . 101

6-3. Waste Loadings, Glass Compositions, Glass Property Predictions, and Additive Composition: AZ Blend Waste . . . . . . . . . . . . . . . . 102

6-4. Waste Loadings, Glass Compositions, Glass Property Predictions, and Additive Composition: $241-\mathrm{C}-106$ Tank Waste . . . . . . . . . . . . . . . 103

6-5. Waste Loading, Measured Glass Properties and Crystalline Phases in the Water Washed and Caustic Washed Nominal Blend Glasses . . . . . . . . . . . . 105 
WHC-SD-WM-TI-768

Revision 0

\section{LIST OF TABLES (CONTINUED)}

6-6. Waste Loading, Measured Property Values, and Crystalline Phases in Water Washed AZ Blend Glasses . . . . . . . . . . . . . . . . . . 106

6-7. Waste Loading, Measured Glass Properties and Crystalline Phases in the Water Washed 241-C-106A and 241-C-106B Glasses . . . . . . . . . . . 107

6-8. Development of Bounding Composition Limits for the (Water Washed) Nominal Blend Glass . . . . . . . . . . . . . 112

6-9. Development of Bounding Composition Limits for the (Caustic Washed) Nominal Blend Glass . . . . . . . . . . . . . . . . . . . . . . . . . . 114

6-10. Development of Bounding Composition Limits for the AZ Blend Glass . . . . . . . . . . . . . . . . . . . . 116

6-11. Development of Bounding Composition Limits for the 241-C-106A Glass . . . . 118

6-12. Development of Bounding Composition Limits for the 241-C-106B Glass . . . . 120

6-13. Properties of the Phase I Experimental Glasses . . . . . . . . . . . 121

6-14. Glass Volume Estimates for Phase I Experimental Glasses . . . . . . . . . . 122

6-15. Glass Volume Estimates for Unblended Phase I Wastes . . . . . . . . . . . . 123

6-16. Glass Volume Estimates for Various Phase I Blends . . . . . . . . . . . . . 124

6-17. Glass Volume as a Function of the Amount of $\mathrm{Al}_{2} \mathrm{O}_{3}$ in Tank $241-A Z-101$ Waste . . . . . . . . . . . . . . . . . . 126

6-18. Glass Volume as a Function of the Amount of $\mathrm{Fe}_{2} \mathrm{O}_{3}$ in Tank 241-AZ-101 Waste

6-19. Glass Volume as a Function of the Amount of $\mathrm{Al}_{2} \mathrm{O}_{3}$ in Tank C-106 Waste . . 134

6-20. Glass Volume as a Function of the Amount of $\mathrm{Fe}_{2} \mathrm{O}_{3}$ in Tank 241-C-106 Waste . . . . . . . . . . . . . . . . . . . . . . . 134

6-21. Tank 241-AZ-101 Base Case Glass Composition . . . . . . . . . . . . . . . 140 
WHC-SD-WM-TI-768

Revision 0

\section{LIST OF TABLES (CONTINUED)}

6-22. Waste Concentration Change Needed to Induce a $50^{\circ} \mathrm{C}$ Change in Liquidus Temperature $\left(T_{L}\right)$ or 5 Percent Change in the Nepheline Limit for Tank 241-AZ-101 Glass . . . . . . . . . . . . . . . . . . . . . . . . . 141

6-23. Tank 241-C-106 Base Case Glass Composition . . . . . . . . . . . . . 141

6-24. Waste Concentration Change Needed to Induce a $50^{\circ} \mathrm{C}$ Change in Liquidus Temperature $\left(T_{\mathcal{L}}\right)$ or 5 Percent Change in the Nepheline Limit for Tank 241-C-106 Glass . . . . . . . . . . . . . . . . . . . . . 142

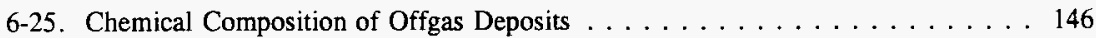

6-26. Plutonium Inventories in Tanks 241-AZ-101, 241-AZ-102, 241-C-106, and

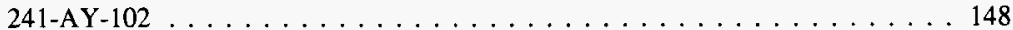

6-27. Maximum Plutonium Oxide Concentration in Phase I Melter Feeds . . . . . . 149

7-1. Glass Volume Estimates for Phase I Experimental Glasses . . . . . . . . . . . 157

7-2. Glass Volume Estimates for Unblended Phase I Wastes $\ldots \ldots \ldots$. . . . . . 158

7-3. Glass Volume Estimates for Various Phase I Blends . . . . . . . . . . . . . . 159

7-4. Glass Volume as a Function of the Amount of $\mathrm{Al}_{2} \mathrm{O}_{3}$ in Tank 241-AZ-101 Waste . . . . . . . . . . . . . . . . . . 161

7-5. Glass Volume as a Function of the Amount of $\mathrm{Al}_{2} \mathrm{O}_{3}$ in Tank 241-C-106 Waste . 163

7-6. Waste Concentration Change Needed to Induce a $50{ }^{\circ} \mathrm{C}$ Change in Liquidus Temperature $\left(T_{L}\right)$ or 5 Percent Change in the Nepheline Limit for Tank 241-AZ-101 Glass . . . . . . . . . . . . . . . . . . . . . . . . . . . 164 
WHC-SD-WM-TI-768

Revision 0

\section{LIST OF ABBREVIATIONS AND ACRONYMS}

$\begin{array}{ll}\text { AFO } & \text { Adjusted feed oxide } \\ \text { BACT } & \text { Best available control technology } \\ \text { CC } & \text { Complexant concentrate } \\ \text { CCC } & \text { Canister centerline cooling } \\ \text { CERCLA } & \text { Comprehensive Environmental Response, Compensation, and Liability Act } \\ \text { CVS } & \text { Composition variability study } \\ \text { CW } & \text { Caustic washed } \\ \text { CWP } & \text { PUREX Coating Waste } \\ \text { DF } & \text { Decontamination factor } \\ \text { DOE } & \text { U.S. Department of Energy } \\ \text { DOE-OCRWM } & \text { U.S. Department of Energy-Office of Environmental Restoration and Waste } \\ & \text { Management } \\ \text { DRE } & \text { Destruction and removal efficiency } \\ \text { DSSF } & \text { Double-shell slurry feed } \\ \text { DST } & \text { Double-shell tank } \\ \text { DWPF } & \text { Defense Waste Processing Facility } \\ \text { EA } & \text { Environmental assessment } \\ \text { ECology } & \text { Washington State Department of Ecology } \\ \text { EDTA } & \text { Ethylenediametetraacetic acid } \\ \text { EIS } & \text { Environmental Impact Statement } \\ \text { FMEA } & \text { Failure modes and effects analysis } \\ \text { FY } & \text { Fiscal year } \\ \text { HEDTA } & \text { N-(hydroxyethyl)-ethylenediaminetriacetic acid } \\ \text { HLW } & \text { High-level waste } \\ \text { HTM } & \text { High-temperature melter } \\ \text { HWVP } & \text { Hanford Waste Vitrification Plant } \\ \text { IDMS } & \text { Integrated DWPF Melter System } \\ \text { IHLW } & \text { Immobilized high-level waste } \\ \text { Kfk } & \text { Kernforschungszentrum Karlsruhe } \\ \text { LANL } & \text { Los Alamos National Laboratory } \\ \text { LAW } & \text { Low-Activity Waste } \\ \text { LFCM } & \text { Liquid-fed ceramic melter } \\ \text { LLW } & \text { Low-level waste } \\ \text { LTM } & \text { Low-temperature melter } \\ \text { MCC } & \text { Materials Characterization Center } \\ \text { MT } & \text { Metric Tons } \\ \text { NBO } & \text { Non-bridging oxygen } \\ \text { NCAW } & \text { Neutralized current acid waste } \\ \text { NCRW } & \text { Neutralized cladding removal waste } \\ \text { ORIGEN } & \text { Oak Ridge Isotope Generation (computer code) } \\ \text { PCCS } & \text { Product composition control system } \\ \text { PCT } & \text { Product consistency test } \\ & \end{array}$




\section{LIST OF ABBREVIATIONS AND ACRONYMS (CONTINUED)}

\begin{tabular}{|c|c|}
\hline PFP & Plutonium Finishing Plant \\
\hline PNNL & Pacific Northwest National Laboratory \\
\hline PSCM & Pilot-scale ceramic melter \\
\hline PUREX & Plutonium-Uranium Extraction \\
\hline QCM & Quasichemical model \\
\hline RCRA & Resource Conservation and Recovery Act of 1976 \\
\hline REDOX & Reduction oxidation \\
\hline RFP & Request for Proposal \\
\hline RLFCM & Radioactive, liquid-fed ceramic melter \\
\hline RSM & Research scale meiter \\
\hline SCF & Shielded cells facility \\
\hline SCR & Selective catalytic reduction \\
\hline SEM/EDS & Scanning electron microscopy/energy dispersive spectroscopy \\
\hline SGM & Scale glass melter \\
\hline SME & Slurry mix evaporator \\
\hline SRS & Strontium removal sludge \\
\hline SRS & Savannah River Site \\
\hline SRTC & Savannah River Technology Center \\
\hline SS & Stainless steel \\
\hline SSHTM & Small-scale high temperature melter \\
\hline SST & Single-shell tank \\
\hline TEM & Transmission electron microscopy \\
\hline TLM & Tank-layer model \\
\hline TOC & Total Organic Carbon \\
\hline TOE & Total online efficiency \\
\hline $\begin{array}{l}\text { Tri-Party } \\
\text { Agreement }\end{array}$ & Hanford Federal Facility Agreement and Consent Order \\
\hline TRU & Transuranic \\
\hline TWRS & Tank Waste Remediation System \\
\hline UR & Uranium Recovery \\
\hline USBM & U.S. Bureau of Mines \\
\hline WAPS & Waste acceptance preliminary specifications \\
\hline WCP & Waste form compliance plan \\
\hline WIPP & Waste Isolation Pilot Plant \\
\hline WOL & Waste oxide loading \\
\hline WQR & Waste for qualification report \\
\hline WSTC & Westinghouse Science and Technology Center \\
\hline WSTRS & Waste Status and Transaction Record Summaries \\
\hline WVDP & West Valley Demonstration Project \\
\hline WW & Water washed \\
\hline XRD & $\mathrm{X}$-ray diffraction \\
\hline
\end{tabular}


WHC-SD-WM-TI-768

Revision 0

\section{TANK WASTE REMEDIATION SYSTEM PHASE I HIGH-LEVEL WASTE FEED PROCESSABILITY ASSESSMENT REPORT}

\subsection{INTRODUCTION}

\subsection{BACKGROUND}

The primary mission of the high-level waste (HLW) program is to process and immobilize the Hanford Site high-level defense waste into a stable borosilicate glass product (or acceptable nonborosilicate waste form) for the Federal geologic repository.

The U.S. Department of Energy (DOE) has determined that this mission will be accomplished by acquiring Hanford Site tank waste treatment and immobilization services using privatized facilities. These facilities will be privately developed, owned, and operated under the requirements of the Resource Conservation and Recovery Act of 1976 (RCRA). Moreover, DOE, the U.S. Environmental Protection Agency, and the Washington State Department of Ecology (Ecology) have entered into the Hanford Federal Facility Agreement and Consent Order, referred to as the Tri-Party Agreement, to ensure compliance with RCRA and the Comprehensive Environmental Response, Compensation, and Liability Act (CERCLA). The Tri-Party Agreement sets forth an aggressive schedule for starting hot operations of the low-activity waste (LAW) pretreatment facility (December 2004) and LAW vitrification facility (June 2005); and commencing hot operations of the HLW pretreatment facility (June 2008) and HLW immobilization facility (December 2009).

It is anticipated that the Hanford Site tank waste disposal mission will be completed in two phases: a Phase I demonstration where 3 to 6 percent of the HLW will be processed at demonstration scale over a period of 5 to 9 years, and a Phase II program where commercial scale facilities will be used to treat the remaining inventory of the Hanford Site's tank waste. The objectives of this initial phase are to demonstrate the commercial feasibility of using private facilities to treat and immobilize the Hanford Site tank waste. After the completion of this initial phase, DOE plans to competitively award contracts for production scale facilities. The Request for Proposal (RFP) for Phase I provides the schedule for the Phase I contract award date (December 29, 1997), completion of design (December 31, 1999), starting hot operations of the HLW immobilization facility (June 1, 2007), processing the minimum quantity of HLW (June 1, 2011), and decontamination and decommissioning and RCRA closure (June 1, 2013).

Most of the HLW technology issues must be resolved before completion of detailed design for Phase I. The objective of this study is to evaluate the composition of the feeds and to analyze the properties of vitrified waste for Phase I HLW privatization. This information is necessary for development of the feed and product (waste form) specifications for the Phase I RFP, to assess the need for caustic washing, to improve estimates of Phase I 


\section{Revision 0}

interim storage requirements (quantity of glass and waste oxide loading) and to provide an acceptable basis for independently evaluating vendor estimates for Phase I glasses (if a glass waste form is proposed). Phase I waste compositions are expected to have a significant affect on the operating performance of a glass melter (melter processing capacity and sludge accumulation potential) and performance properties of the glass.

The volume and composition of waste in the single-shell tanks (SSTs) and double-shell tanks (DSTs) vary significantly (Hanlon 1994). Before 1992, the Hanford Waste Vitrification Plant (HWVP) scope was limited to processing only DST waste, which includes neutralized current acid waste (NCAW), neutralized cladding removal waste (NCRW), Plutonium Finishing Plant (PFP) waste, and complexant concentrate (CC) waste. These wastes contain high concentrations of chromium, zirconium, and noble metals ( $\mathrm{Ag}, \mathrm{Pd}, \mathrm{Rh}$, $\mathrm{Te}$, and $\mathrm{Ru}$ ) that may require special pretreatment or blending to avoid possible sludge accumulation problems in the melter. With the addition of SST wastes, the waste composition envelope has expanded to include other wastes known to be high in aluminum, phosphate, chromium, and uranium, that may limit the acceptable glass composition range and increase the volume of HLW glass produced. Such wastes must be thoroughly characterized to ensure that the vitrification process will produce glasses (or alternate waste forms) of acceptable quality for the waste repository.

In-tank sludge washing and caustic leaching processes can be used to reduce the level of certain non-radioactive and glass limiting components in the waste. These processes are especially needed to reduce the amount of sodium, aluminum, chrome, sulfur, and phosphorus in the HLW melter feed and to add these components to the low activity stream for LAW vitrification. Laboratory studies have indicated that these processes are likely to be effective for certain wastes and will reduce the volume of HLW glass and improve performance characteristics of the HLW melter.

Better estimates of the pretreated waste and melter feed compositions are needed to support the design and operation of the HLW immobilization facility. Compositions derived from tank waste composition models, characterization data and process flowsheet, and simulation models of the pretreatment and vitrification processes will be evaluated to ensure that the pretreated waste can be processed, as required, into a qualified glass product (or acceptable alternate waste form).

Since the alternate waste forms have not been identified, this study will be limited to borosilicate glass as the preferred waste form for the Phase I HLW.

\subsection{PURPOSE}

The purpose of this report is to provide vitrification basis for pretreatment and blending of Phase I HLW and to evaluate the impact of feed composition on operation of the HLW immobilization facility. This includes developing estimates of total HLW glass volume based 
on limiting components in the waste using different scenarios for tank waste blending and pretreatment, and on glass composition ranges and limits.

\subsection{SCOPE}

This assessment focuses on estimating the composition of wastes for Phase I HLW immobilization, processing those wastes through the pretreatment and vitrification functions, evaluating melter performance characteristics, and estimating the volume and composition of the HLW glasses. Estimates of the waste oxide loading (WOL) and glass composition will be determined for Phase I wastes and blends of those wastes. Potential benefits of sludge washing and caustic leaching will be assessed to determine the likely impact on glass volume. Each HLW glass will be evaluated for acceptable viscosity, electrical conductivity and absence of crystals at the melter operating temperature, and acceptable leach resistance after disposal. Glass volume predictions will be generated based on the limiting properties of the glass, including liquidus temperature and nepheline constraints. This assessment will address balance of plant issues, considering corrosion of offgas system components, volatile emissions, and offgas treatment.

This document will be revised periodically as new information on the properties and composition of Phase I wastes becomes available. Previous assessments, including the Hanford Waste Vitrification Plant Melter Feed Criteria Recommendation (Stegen and Baker 1990) and Hanford Waste Vitrification Plant Feed Processability Assessment (May and Watrous 1991), evaluated the acceptability of estimated HWVP (DST) feed compositions and identified those areas where feed composition would have an adverse affect on the operability of the HWVP. The scope of this assessment includes only those wastes selected for Phase I HLW immobilization and focuses on the integrated performance of the retrieval and pretreatment functions and HLW immobilization process. Tank characterization data will be used to construct estimates of the average and bounding melter feed compositions and related glass composition limits for the HLW plant. Later revisions to this document will discuss the planning and processing impacts of waste retrieval, blending, and sludge pretreatment processes for Phase II HLW feeds and how these processes should be integrated into the Hanford Site flowsheet (Orme 1995). 
WHC-SD-WM-TI-768

Revision 0

This page intentionally left blank. 
WHC-SD-WM-TI-768

Revision 0

\subsection{PHASE I HIGH-LEVEL WASTES}

The HLW immobilization facility will receive waste under conditions described in the RFP and will process those wastes to make a vitrified glass product. This section describes: (1) the selection of candidate Phase I wastes based on waste consolidation plans, (2) the origin and principal characteristics of this waste, and (3) estimated compositions based on sludge samples from the candidate tanks. Tank waste compositions developed from this assessment will be used to derive composition estimates for water and caustic washed sludges and to develop melter feed composition estimates for various feed batches or waste blends in Section 3.0. These compositions will also used to determine the composition and properties of the corresponding HLW glasses in Section 6.0.

\subsection{SELECTION OF PHASE I WASTES}

The candidate HLW feeds for Phase I are NCAW in Tanks 241-AZ-101 and 241-AZ-102, and high-heat sludge retrieved from Tank 241-C-106 into Tank 241-AY-102 (Bacon 1996). Prewashed solids being prepared for HLW processing will be stored in three tanks (241-AZ-101, 241-AZ-102, and 241-AY-102). It is unlikely that any of these wastes will be mixed until the tank safety issues have been resolved, including: (1) heat and sludge height removal limits for Tanks 241-AZ-101 and 241-AZ-102, (2) criticality limits for Tanks 241-AZ-101 and 241-AZ-102, (3) the five molar sodium concentration limit for aging tank waste supernatants, and (4) the radionuclide source term limits for 242 -A evaporator processing of supernates.

Sludges in Tanks 241-AZ-101, 241-AZ-102 and 241-AY-102 may be subsequently leached and washed, if necessary, before transfer of these wastes to the HLW immobilization facility. However, tank space management and conservation needs, and tank safety risk considerations may limit the possible use of caustic leaching processes for these waste (Powell 1995).

\subsection{SOURCE OF WASTES}

Tank 241-AZ-101 wastes primarily consist of NCAW from the last Plutonium-Uranium Extraction (PUREX) production campaign, that were transferred into Tank 241-AZ-101 from 1983 through March 13, 1986. Before this transfer, approximately $21,500 \mathrm{~L}$ of sludge remained as a residual heel in this tank. The current inventory in Tank 241-AZ-101 is approximately $130,000 \mathrm{~L}$ of sludge (Hodgson 1995). Tank 241-AZ-102 waste is similar in most respects, consisting of NCAW waste transferred to Tank 241-AZ-102 from March 13, 1986 , through the end of the last PUREX production campaign in 1989. Before the initial transfers of NCAW waste, Tank 241-AZ-102 contained about $31,500 \mathrm{~L}$ of sludge from other unspecified sources. The current inventory in Tank $241-\mathrm{AZ}-102$ is approximately $333,000 \mathrm{~L}$ of sludge (Ryan 1995). 
Tank 241-AY-102 wastes mainly consist of settled solids from dilute supernate transfers $(66,000,000$ to $68,000,000 \mathrm{~L})$, aging waste transfers from 1977 to 1978 , double-shell slurry feed (DSSF) transfers in 1980, and dilute, non-complexed waste after 1980. The original sources include B Plant, PUREX, SSTs, 100 Area, 300 Area, 400 Area, T Plant, S Plant, and various DSTs. The sludge volume was initially determined to be $23,000 \mathrm{~L}$ on September 14,1978 . Approximately $2,700 \mathrm{~L}$ of this total may have consisted of sodium aluminate rich sludge from DSSF, while the remaining sludge was probably from NCAW and commercial vitrification process waste. The sludge inventory increased to $80,000 \mathrm{~L}$ by June 30,1980 , including $57,000 \mathrm{~L}$ of sludge from DSSF waste.

Currently, Tank 241-AY-102 contains $121,000 \mathrm{~L}$ of sludge from various unidentified sources. The chemical composition of this sludge, including the ratio of aluminum to iron, is consistent with PUREX type sludges from B Plant, while the high silver and chloride inventories in this waste $(559 \mathrm{~kg}$ and $644 \mathrm{~kg}$, respectively) suggests the possible receipt of silver catalyst from the B Plant cesium and strontium purification operations of Isochem (involving less than $1,270 \mathrm{~kg} \mathrm{Ag}$ ) (Buckingham 1967).

The LANL Tank Layer Model (TLM) can be used as a basis for estimating the sludge layers in Tank 241-C-106 (Agnew 1995). According to this model, Tank 241-C-106 waste mainly consists of: (1) uranium recovery process sludge (UR waste) $(102,000 \mathrm{~L}),(2)$ PUREX coating waste (CWP) $(128,700 \mathrm{~L})$, (3) washed PUREX sludge from B Plant cesium/strontium recovery operations (AR vault waste) $(242,200 \mathrm{~L})$, (4) LLW from B Plant operations (BL waste) $(75,500 \mathrm{~L})$, and (5) unknown waste (probably AR and BL waste) from B Plant (196,800 L) (Agnew 1995).

\subsection{GENERAL CHARACTERISTICS OF WASTES}

Approximately 1,877 ML of waste have been produced at the Hanford Site by the reprocessing of irradiated fuel from the plutonium production reactors. The principal chemical separation processes include the bismuth phosphate process (T and B Plants, 1944 to 1956), the reduction oxidation (REDOX) process (1952 to 1966), and the PUREX solvent extraction process (1956 to 1972,1983 to 1989). Certain tank wastes, such as the metal waste stream from the bismuth phosphate process, were reworked in U Plant to recover uranium (uranium recovery process, 1952 to 1957). During the same period, low-level supernate wastes were treated to remove ${ }^{137} \mathrm{Cs}$ and ${ }^{90} \mathrm{Sr}$ before disposing of such wastes to cribs or trenches (nickel ferrocyanide scavenging operations disposing of $325 \mathrm{ML}$ of waste). From 1965 to 1976 , high-heat PUREX waste sludges and general supernate wastes were reworked in B Plant to recover ${ }^{137} \mathrm{Cs}$ and ${ }^{90} \mathrm{Sr}$ by ion exchange and solvent extraction, respectively (cesium and strontium encapsulation operation). 
Because of severe limitations in tank space, some wastes were concentrated by in-tank evaporation or external evaporation processes (242-B and T evaporators, in-tank BY-ITS, $\mathrm{S}$, and SX farm evaporators and 242-A and S evaporator-crystallizers) with condensates being routed to cribs and trenches, recycled to other tanks or treated for subsequent disposal. Approximately 1,139 ML of waste water were eventually eliminated by various evaporation processes. By employing such processes, wastes in SST farms were gradually converted into mixed sludges and salt cake, while most of the recent wastes from PUREX and supernates from older wastes have been consolidated into the double-shell tank farms. Approximately $174 \mathrm{ML}$ of waste remain in the tanks from the 1944 to 1980 era, together with $57 \mathrm{ML}$ of concentrated waste from recent operations at the Hanford Site.

Figures 2-1 and 2-2 show the composition of the principal streams from the uranium recovery process (UR sludge) and from the PUREX and B Plant processes (PUREX coating waste, neutralized PUREX HLW, and washed PUREX sludge from B Plant) (GE 1951 and 1955, RHO 1980). These waste compositions may be used with the tank transaction records to identify the tanks that received the wastes and as a basis for estimating the possible composition of this waste.

In-tank precipitation and mineralization processes have also changed the solubility properties of some components in the waste, such as sodium, aluminum, and $\mathrm{NO}_{3}$ in cancrinite $\left(2 \mathrm{NaAlSiO}_{4}-0.52 \mathrm{NaNO}_{3}-0.68 \mathrm{H}_{2} \mathrm{O}\right)$, aluminosilicate and iron bismuth silicate hydroxide. Such wastes are often highly stratified with lateral and vertical inhomogeneities caused by the mixing and settling characteristics of the sludge, that makes it especially difficult in many cases to obtain a representative sample of the waste. 


\section{WHC-SD-WM-TI-768 \\ Revision 0}

Figure 2-1. Composition of the Principal Streams from the Uranium Recovery Process.

\section{Uranium recovery process}

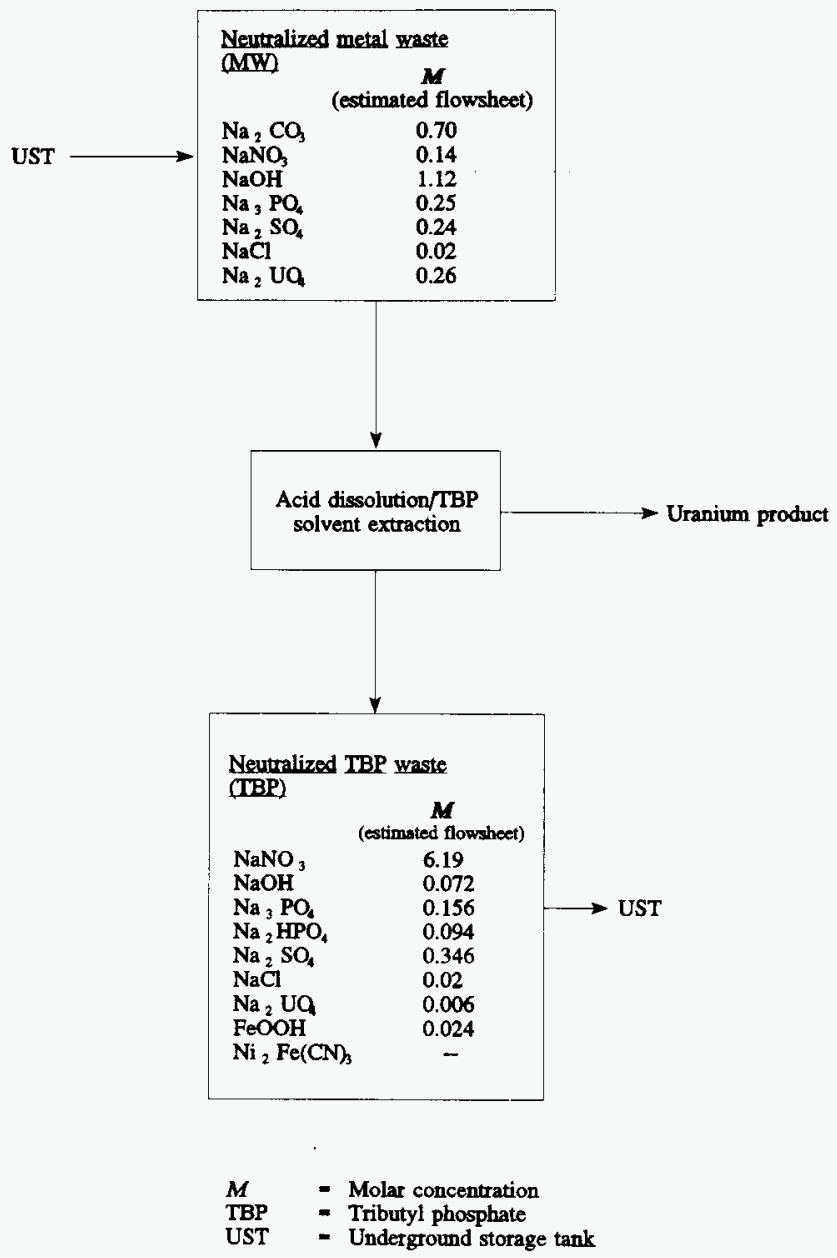


WHC-SD-WM-TI-768

\section{Revision 0}

Figure 2-2. Composition of the Principal Streams from PUREX and B Plant Processes.

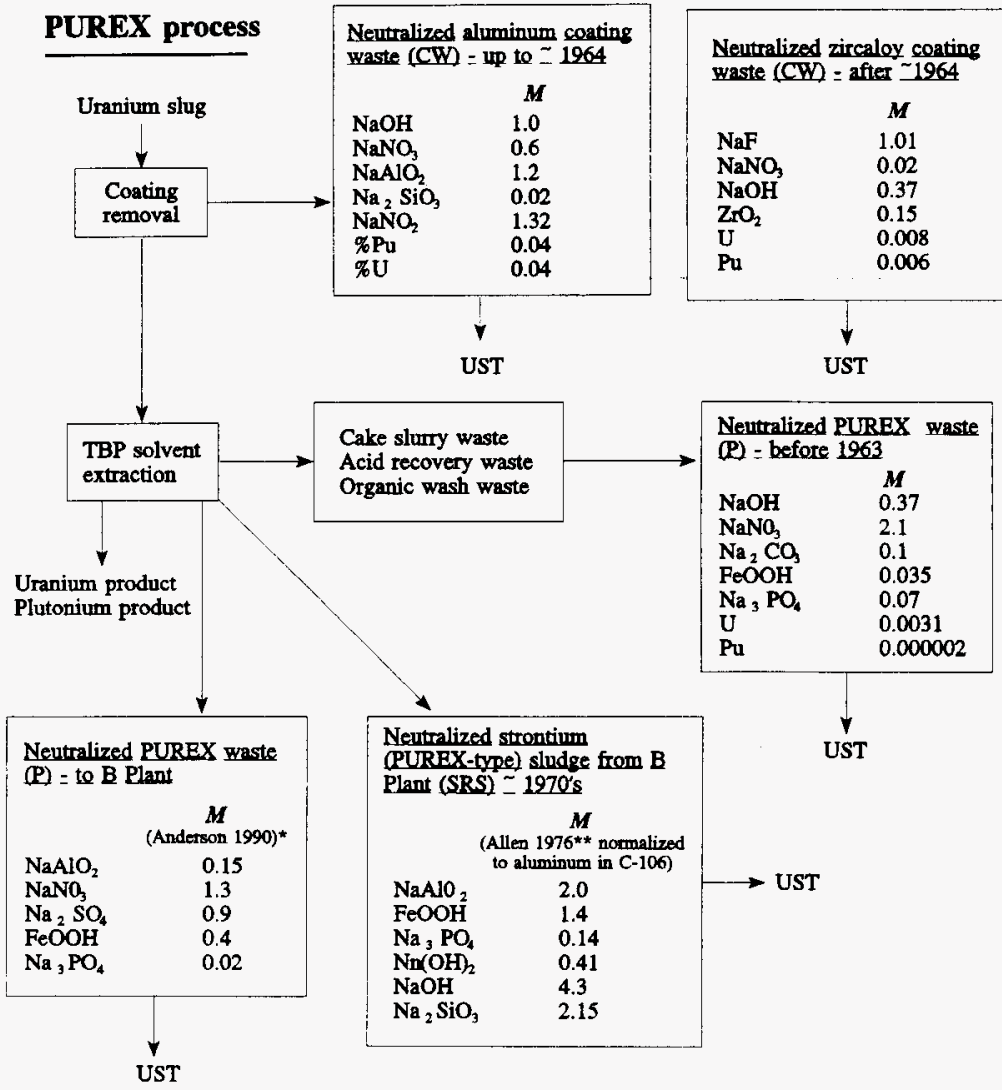

* Anderson, J.D., 1990, A History of the 200 Area Tank Farms, WHC-MR-0132, Wesinghouse Hanford Company, Richland, Washington.

** Allen, G. K., 1976, Estimated Imventory of Chemicals Added to Underground Waste Tanks, 1944 Through 1975, ARH-CD-610 B, Atlantic Richfield Hanford Company, Richland, Washington.

$M=$ Molar concentration PUREX - Plutionium-Uranium Extraction SRS - Strontium removal sludge

TBP = Tributyl phosphate

UST - Underground storage tank 
WHC-SD-WM-TI-768

Revision 0

This page intentionally left blank. 


\subsection{CURRENT ESTIMATES OF MELTER FEED COMPOSITION}

This section provides estimates of the HLW melter feed composition based on available data. Estimates provided in this section are based on analysis of core samples and water washing tests performed with these samples, essential materials purchase records and for some components, flowsheets and fission yields keyed to the estimated ruthenium inventory (Hogan 1994, Enghusen 1987, Schofield 1989, 1990). These sources were used to estimate the composition of the sludge in Tanks 241-AZ-101, 241-AZ-102, 241-C-106, and 241-AY-102. At least one full depth core sample has been taken from each of these tanks. Core sample analysis reports and sludge level measurements were primarily used to determine the composition of most components in the Phase I wastes. This information is currently available from the Tank Characterization Reports for 241-AZ-101, 241-AZ-102, and 241-AY-102, and from the Data Transmittal package for 241-C-106 (Hodgson 1995, Ryan 1995, Gray 1993a, 1993b, Weiss 1987, McCown 1988, Hara 1990, Horton 1977, Bratzel 1980). The current inventory estimates for Tank 241-AZ-101 are based on the physical and chemical properties of the cores and average sludge level when the samples were taken in May 1989. The amount of aluminum in the waste of Tank 241-AZ-101 was estimated from essential materials purchase records and the analysis of supernate samples from this tank. It is anticipated that all Phase I wastes will be extensively water washed to remove most of the water soluble components, and for some wastes, caustic washing processes may be employed to reduce the amount of aluminum in these wastes. The melter feed composition estimates provided in this section assume that 88 percent of the water soluble components have been removed from the sludge during the waste retrieval and sludge washing operations in the tank farm.

\subsection{1-AZ-101 TANK WASTE}

Approximately 20 samples of waste from Tank 241-AZ-101 have been obtained since 1983, including several grab samples of liquid and sludge in 1987 and 1995. Tank 241-AZ-101 also was sampled in April and May of 1989, using a push-mode sampler to retrieve three core samples of sludge. About $200 \mathrm{~g}$ of sludge were recovered in the first core. Based on the physical properties of the core (density and solids weight), the first sludge layer appeared to be $23.2 \mathrm{~cm}(9.14 \mathrm{in}$.) thick at riser $15 \mathrm{~F}$ where the first core sample was taken. About $513 \mathrm{~g}$ of sludge were obtained from the second core, corresponding to a sludge layer thickness of approximately $61 \mathrm{~cm}(24 \mathrm{in}$.) at riser 24D where this sample was taken. This value is in good agreement with the $58.4 \mathrm{~cm}(23 \mathrm{in}$.) sludge level that was measured from riser $24 \mathrm{D}$ several months before the core sample was taken. If the sludge depth corresponding to the core sample data from riser 24D is included with data from the other risers in calculating sludge depth, the average sludge level is $39.2 \mathrm{~cm}(15.43 \mathrm{in}$.), corresponding to a sludge inventory of $161,000 \mathrm{~L}$. This figure was used to estimate component inventories in Tank 241-AZ-101. During the analysis of the core samples, sludge and liquid from the core were composited and subjected to water washing tests using a 


\section{Revision 0}

gravity settling/liquid decant procedure. The tank waste composition estimates for this waste are provided in Table 3-1.

\subsection{1-AZ-102 TANK WASTE}

Several grab samples of liquid and sludge were obtained in 1987, and a two segment core of the sludge in May and July 1989, from Tank 241-AZ-102. Other dip samples were collected as recently as February 1995. The 1989 core sample was taken from riser 15L and contained $268 \mathrm{~g}$ of solids and $25 \mathrm{~g}$ of free draining liquid in the first segment and $287 \mathrm{~g}$ of solids and negligible liquid in the second segment. Based on the physical properties and appearance of the core, the sludge layer appeared to be $85.4 \mathrm{~cm}(33.6 \mathrm{in}$.) thick at the location of the core sample. This estimate is consistent with the sludge level measurements taken on May 30, 1989. The average layer was $81.12 \mathrm{~cm}$ (31.94 in.) thick on May 30, 1989. Based on these results, the inventory at the time of sampling was $333,000 \mathrm{~L}$ of sludge (Hanlon 1993). The sludge and liquid samples from this core were composited and subjected to a similar series of water washing tests. The tank waste composition estimates are provided in Table 3-2.

\subsection{1-AY-102 TANK WASTE}

A core sample of sludge was taken in 1987 and grab samples of liquid in June and December 1994 from Tank 241-AY-102. The core sample, taken from riser 13A, consisted of two segments that were divided into four subsamples, three of which contain solids and the other supernate and about one percent solids from the top segment of the core. The sludge volume at the time of the 1987 core sample was $121,000 \mathrm{~L}(32,000 \mathrm{gal})$. This volume is consistent with the current sludge inventory in Tank 241-AY-102 (Hanlon 1993). The estimated composition of this waste is provided in Table 3-3.

\subsection{1-C-106 TANK WASTE}

Several samples of liquid and sludge were obtained from Tank 241-C-106 in 1977 and 1980 , and a four segment core sample of sludge from riser 1 in 1986. About $1,300 \mathrm{~g}$ of sludge and $80 \mathrm{ml}$ of liquid were recovered in the 1986 core sample. Base on the physical properties of the core, the sludge layer appeared to be $193 \mathrm{~cm}$ (76 in.) thick at the sampling location. This sludge depth is consistent with sludge level measurements that, at the time of sampling, indicate the sludge layer was $196.3 \mathrm{~cm}(77.3 \mathrm{in}$.) thick. The current inventory is about $745,000 \mathrm{~L}$ corresponding to an average sludge depth of $181.6 \mathrm{~cm}(71.5 \mathrm{in}$.). (Hanlon 1993). A composite sample of $239.5 \mathrm{~g}$ of sludge was formed from the core material. Water washing and acid leaching tests (with $\mathrm{HNO}_{3}$ and $\mathrm{HNO}_{3}-\mathrm{HF}-\mathrm{HCl}$ ) were performed using a centrifuge separation/liquid decant procedure. The tank waste composition estimates for this waste are provided in Table 3-4. 
Table 3-1. Tank 241-AZ-101 Waste Composition.

\begin{tabular}{|c|c|c|c|c|c|c|c|c|c|c|c|}
\hline 241-AZ-101 Element & $\begin{array}{l}\text { Element } \\
\text { wt kg }\end{array}$ & $\begin{array}{c}241-\mathrm{AZ} \\
101 \text { Oxide }\end{array}$ & $\begin{array}{l}\text { Oxide } \\
\text { factor }\end{array}$ & $\begin{array}{c}\text { Oxide wt } \\
\mathrm{kg}\end{array}$ & $\begin{array}{l}\text { Oxide } \\
\text { wt\% }\end{array}$ & $\begin{array}{l}\text { Water } \\
\text { wash } \\
\text { factor }\end{array}$ & $\begin{array}{c}\text { Water } \\
\text { wash } \\
\text { solids, kg }\end{array}$ & $\begin{array}{l}\text { Water } \\
\text { wash } \\
\text { solid. } \\
\text { wr\% }\end{array}$ & $\begin{array}{c}\text { Caustic } \\
\text { wash } \\
\text { factor }\end{array}$ & $\begin{array}{c}\text { Coustic } \\
\text { wash } \\
\text { solids. } \\
\text { kg } \\
\end{array}$ & $\begin{array}{c}\text { Caustic } \\
\text { wash } \\
\text { solids. } \\
\text { wt\% } \\
\end{array}$ \\
\hline Al & 13384.00 & $\mathrm{~A}: 203$ & 1.89 & 25282.38 & 20.74 & 1.00 & 25282.38 & 23.15 & 0.52 & 13146.8 & 13.69 \\
\hline As & 136.30 & As203 & 1.32 & 179.92 & 0.15 & 1.00 & 179.92 & 0.16 & 1.00 & 179.92 & 0.19 \\
\hline $\mathrm{Ba}$ & 174.90 & $\mathrm{BaO}$ & 1.12 & 195.19 & 0.16 & 1.00 & 195.19 & 0.18 & 1.00 & 195.19 & 0.20 \\
\hline $\mathrm{Be}$ & 4.21 & $\mathrm{BeO}$ & 2.78 & 11.68 & 0.01 & 1.00 & 11.68 & 0.01 & 1.00 & 11.68 & 0.01 \\
\hline B & 71.80 & $\mathrm{~B} 2 \mathrm{O} 3$ & 3.21 & 230.26 & 0.19 & 1.00 & 230.26 & 0.21 & 1.00 & 230.26 & 0.24 \\
\hline $\mathbf{C a}$ & 587.00 & $\mathrm{CaO}$ & 1.40 & 821.21 & 0.67 & 1.00 & 821.21 & 0.75 & 1.00 & 821.21 & 0.86 \\
\hline $\mathrm{Cd}$ & 1357.35 & $\mathrm{CdO}$ & 1.14 & 1550.09 & 1.27 & 1.00 & 1550.09 & 1.42 & 1.00 & 1550.09 & 1.61 \\
\hline $\mathrm{Ce}$ & 293.27 & $\mathrm{CeO} 2$ & 1.23 & 360.14 & 0.30 & 1.00 & 360.14 & 0.33 & 1.00 & 360.14 & 0.38 \\
\hline $\mathrm{Cl}$ & 26.75 & $\mathrm{Cl}-$ & 1.00 & 26.75 & 0.02 & 0.74 & 19.80 & 0.02 & 1.00 & 19.80 & 0.02 \\
\hline $\mathrm{Cr}$ & 398.00 & $\mathrm{Cr} 2 \mathrm{O} 3$ & 1.46 & 581.48 & 0.48 & 0.70 & 407.03 & 0.37 & 0.89 & 362.26 & 0.38 \\
\hline Co & 279.89 & $\mathrm{Co} 203$ & 1.41 & 393.81 & 0.32 & 1.00 & 393.81 & 0.36 & 1.00 & 393.81 & 0.41 \\
\hline $\mathrm{Cu}$ & 104.65 & $\mathrm{CuO}$ & 1.25 & 131.02 & 0.11 & 1.00 & 131.02 & 0.12 & 1.00 & 131.02 & 0.14 \\
\hline Dy & 20.43 & Dy203 & 1.15 & 23.43 & 0.02 & 1.00 & 23.43 & 0.02 & 1.00 & \begin{tabular}{|l|}
23.43 \\
\end{tabular} & 0.02 \\
\hline $\mathbf{F}$ & 544.67 & F- & 1.00 & 544.67 & 0.45 & 0.41 & 223.31 & 0.20 & 1.00 & 223.31 & 0.23 \\
\hline $\mathrm{Fe}$ & 24086.84 & $\mathrm{Fe} 203$ & 1.43 & 34444.18 & 28.26 & 1.00 & 34444.18 & 31.54 & 1.00 & 34444.1 & 35.87 \\
\hline $\mathrm{La}$ & 910.76 & $\mathrm{La2O3}$ & 1.17 & 1068.32 & 0.88 & 1.00 & 1068.32 & 0.98 & 1.00 & 1068.32 & 1.11 \\
\hline $\mathrm{Pb}$ & 127.70 & $\mathrm{PbO}$ & 1.08 & 137.53 & 0.11 & 1.00 & 137.53 & 0.13 & 1.00 & 137.53 & 0.14 \\
\hline $\mathrm{Li}$ & 17.59 & $\mathrm{Li2O}$ & 2.15 & 37.85 & 0.03 & 1.00 & 37.85 & 0.03 & 1.00 & 37.85 & 0.04 \\
\hline $\mathrm{Mg}$ & 147.25 & $\mathrm{MgO}$ & 1.66 & 244.14 & 0.20 & 1.00 & 244.14 & 0.22 & 1.00 & 244.14 & 0.25 \\
\hline Mn & 728.34 & $\mathrm{MnO} 2$ & 1.58 & 1152.23 & 0.95 & 1.00 & 1152.23 & 1.06 & 1.00 & 1152.23 & 1.20 \\
\hline Mo & 26.75 & MoO3 & 1.50 & 40.13 & 0.03 & 1.00 & 40.13 & 0.04 & 1.00 & 40.13 & 0.04 \\
\hline $\mathrm{Nd}$ & 651.43 & $\mathrm{~N}+203$ & 1.17 & 760.22 & 0.62 & 1.00 & 760.22 & 0.70 & 1.00 & 760.22 & 0.79 \\
\hline $\mathrm{Ni}$ & 1073.75 & $\mathrm{NiO}$ & 1.27 & \begin{tabular}{|l|}
1366.88 \\
\end{tabular} & 1.12 & 1.00 & 1366.88 & 1.25 & 1.00 & \begin{tabular}{|l|}
366.88 \\
\end{tabular} & 1.42 \\
\hline $\mathrm{P}$ & 674.47 & $\mathrm{P} 205$ & 2.29 & 1545.21 & 1.27 & 1.00 & 1545.21 & 1.41 & 0.34 & 525.37 & 0.55 \\
\hline $\mathrm{Pu}$ & 14.87 & $\mathrm{PuO2}$ & 1.13 & 16.82 & 0.01 & 1.00 & 16.82 & 0.02 & 1.00 & 16.82 & 0.02 \\
\hline $\mathbf{K}$ & 1420.52 & $\mathrm{~K} 20$ & 1.21 & 1711.73 & 1.40 & 1.00 & 1711.73 & 1.57 & 1.00 & 1711.73 & 1.78 \\
\hline $\operatorname{Re}$ & 13.87 & $\mathrm{Re} 203$ & 1.13 & 15.66 & 0.01 & 1.00 & 15.66 & 0.01 & 1.00 & 15.66 & 0.02 \\
\hline $\mathrm{Rh}$ & 105.15 & $\mathrm{Rh} 203$ & 1.23 & 129.65 & 0.11 & 1.00 & 129.65 & 0.12 & 1.00 & 129.65 & 0.14 \\
\hline $\mathrm{Ru}$ & 214.00 & Ru203 & 1.23 & 263.22 & 0.22 & 1.00 & 263.22 & 0.24 & 1.00 & 263.22 & 0.27 \\
\hline Sh & 656.38 & $\mathrm{Sb} 203$ & 1.20 & 785.69 & 0.64 & 1.00 & 785.69 & 0.72 & 1.00 & 785.69 & 0.82 \\
\hline $\mathrm{Se}$ & 432.97 & $\mathrm{SeO} 2$ & 1.41 & 608.32 & 0.50 & 1.00 & 608.32 & 0.56 & 1.00 & 608.32 & 0.63 \\
\hline Si & 1410.61 & $\mathrm{SiO} 2$ & 2.14 & 3017,29 & 2.48 & 1.00 & 3017.29 & 2.76 & 1.00 & 3017.29 & 3.14 \\
\hline $\mathrm{Ag}$ & 98.95 & $\mathrm{Ag} 2 \mathrm{O}$ & 1.07 & 106.27 & 0.09 & 1.00 & 106.27 & 0.10 & 1.00 & 106.27 & 0.11 \\
\hline $\mathrm{Na}$ & 18058.00 & $\mathrm{Na2O}$ & 1.35 & 24342.18 & 19.97 & 0.60 & 14605.31 & 13.37 & 1.00 & 14605.3 & 15.21 \\
\hline Sr & 119.88 & $\mathrm{SrO}$ & 1.18 & 141.82 & 0.12 & 1.00 & 141.82 & 0.13 & 1.00 & 141.82 & 0.15 \\
\hline so4 & 3485.00 & $\mathrm{SO} 4$ & 1.00 & 3485.00 & 2.86 & 0.30 & 1045.50 & 0.96 & 1.00 & 1045.50 & 1.09 \\
\hline $\mathrm{Te}$ & 464.67 & $\mathrm{TeO} 2$ & 1.25 & 582.23 & 0.48 & 1.00 & 582.23 & 0.53 & 1.00 & 582.23 & 0.61 \\
\hline Th & 299.46 & $\mathrm{ThO}_{2}$ & 1.14 & 340.79 & 0.28 & 1.00 & 340.79 & 0.31 & 1.00 & 340.79 & 0.35 \\
\hline $\mathrm{T}_{\mathrm{i}}$ & 158.77 & $\mathrm{TiO} 2$ & 1.67 & 264.83 & 0.22 & 1.00 & 264.83 & 0.24 & 1.00 & 264.83 & 0.28 \\
\hline $\mathrm{Tl}$ & 1619.54 & T1203 & 1.12 & 1809.03 & 1.48 & 1.00 & 1809.03 & 1.66 & 1.00 & 1809.03 & 1.88 \\
\hline $\mathrm{U}$ & 1328.37 & U308 & 1.18 & 1566.15 & 1.28 & 1.00 & 1566.15 & 1.43 & 1.00 & 1566.15 & 1.63 \\
\hline V & 6.19 & $\mathrm{~V} 205$ & 1.79 & 11.05 & 0.01 & 1.00 & 11.05 & 0.01 & 1.00 & 11.05 & 0.01 \\
\hline $\mathrm{Zn}$ & 97.59 & $\mathrm{ZnO}$ & 1.24 & 121.40 & 0.10 & 1.00 & 121.40 & 0.11 & 1.00 & 121.40 & 0.13 \\
\hline $\mathrm{Zr}$ & 8478.51 & $\mathrm{ZrO2}$ & 1.35 & 11445.99 & 9.39 & 1.00 & 11445.99 & 10.48 & 1.00 & \begin{tabular}{|l|}
11445.9 \\
\end{tabular} & 11.92 \\
\hline Total Cation,kg & 84311.40 & \multicolumn{2}{|c|}{ Total Oxides } & 121893.8 & 100 & & 109214.7 & 100 & & 96014.5 & 100 \\
\hline $\begin{array}{l}\text { Total Arions (NO2,NO3, } \\
\text { TIC as } \mathrm{CO} 3), \mathrm{kg}\end{array}$ & 31283.50 & & & & & & & & & & \\
\hline Water. kg & 115090.00 & & & & & & & & & & \\
\hline $\begin{array}{l}\text { Total sludge } \mathrm{kg} \text { (den }= \\
1.66 \mathrm{~kg} / 42.05 \% \text { water })\end{array}$ & 230684.90 & & & & & & & & & & \\
\hline Total estimated sludge, $\mathrm{kg}$ & 267260.00 & & & & & & & & & & \\
\hline Mass balance percent & 86.46 & & & & & & & & & & \\
\hline Missing: & $\mathrm{Ox}_{1}$ & & & & & & & & & & \\
\hline
\end{tabular}


WHC-SD-WM-TI-768

Revision 0

Table 3-2. Tank 241-AZ-102 Waste Composition. (2 sheets)

\begin{tabular}{|c|c|c|c|c|c|c|c|c|c|c|c|}
\hline Element & $\begin{array}{l}\text { Element } \\
\text { wt kg }\end{array}$ & Oxide & $\begin{array}{l}\text { Oxide } \\
\text { factor }\end{array}$ & $\begin{array}{c}\text { Oxide wt } \\
\text { kg }\end{array}$ & $\begin{array}{l}\text { Oxide } \\
\text { wt\% }\end{array}$ & $\begin{array}{l}\text { Water } \\
\text { wash } \\
\text { factor }\end{array}$ & $\begin{array}{c}\text { Water wash } \\
\text { solids, } \mathrm{kg}\end{array}$ & $\begin{array}{c}\text { Water } \\
\text { wash } \\
\text { solids. } \\
w t \%\end{array}$ & $\begin{array}{c}\text { Caustic } \\
\text { wash } \\
\text { factor }\end{array}$ & $\begin{array}{c}\text { Caustic } \\
\text { wash } \\
\text { solids, kg }\end{array}$ & $\begin{array}{c}\text { Caustic } \\
\text { wash } \\
\text { solids. } \\
\text { wt\% }\end{array}$ \\
\hline $\mathrm{Al}$ & 19184.00 & $\mathrm{Al2O3}$ & 1.89 & 36238.58 & 20.06 & 1.00 & 36238.58 & 20.95 & 0.52 & 18844.06 & 12.16 \\
\hline As & 211.48 & As203 & 1.32 & 279.15 & 0.15 & 1.00 & 279.15 & 0.16 & 1.00 & 279.15 & 0.18 \\
\hline $\mathrm{Ba}$ & 197.55 & $\mathrm{BaO}$ & 1.12 & 220.47 & 0.12 & 1.00 & 220.47 & 0.13 & 1.00 & 220.47 & 0.14 \\
\hline $\mathrm{Be}$ & 4.80 & $\mathrm{BeO}$ & 2.78 & 13.32 & 0.01 & 1.00 & 13.32 & 0.01 & 1.00 & 13.32 & 0.01 \\
\hline$B$ & $\begin{array}{ll}177.54 \\
\end{array}$ & B203 & 3.21 & 569.37 & 0.32 & 1.00 & 569.37 & 0.33 & 1.00 & 569.37 & 0.37 \\
\hline $\mathrm{Ca}$ & 1078.87 & $\mathrm{CaO}$ & 1.40 & 1509.34 & 0.84 & 1.00 & 1509.34 & $\begin{array}{ll}0.87 \\
\end{array}$ & 1.00 & 1509.34 & 0.97 \\
\hline $\mathrm{Cd}$ & 5358.64 & $\mathrm{CdO}$ & 1.14 & 6119.57 & 3.39 & 1.00 & -6119.57 & 3.54 & 1.00 & 6119.57 & 3.95 \\
\hline $\mathrm{Ce}$ & 280.43 & $\mathrm{CeO} 2$ & 1.23 & 344.37 & 0.19 & 1.00 & 344.37 & 0.20 & 1.00 & 344.37 & 0.22 \\
\hline $\mathrm{Cl}$ & 52.51 & Cl- & 1.00 & 52.51 & 0.03 & 0.60 & 31.51 & 0.02 & 1.00 & 31.51 & 0.02 \\
\hline$\overline{C r}$ & 685.90 & $\mathrm{Cr} 2 \mathrm{O} 3$ & 1.46 & 1002.10 & 0.55 & 0.87 & 871.83 & 0.50 & 0.89 & 775.93 & 0.50 \\
\hline $\mathrm{Co}$ & 525.14 & $\mathrm{Co} 203$ & I.41 & 738.87 & 0.41 & 1.00 & 738.87 & 0.43 & 1.00 & 738.87 & 0.48 \\
\hline $\mathrm{Cu}$ & 125.03 & $\mathrm{CuO}$ & 1.25 & 156.54 & 0.09 & 1.00 & 156.54 & 0.09 & 1.00 & 156.54 & 0.10 \\
\hline Dy & 18.00 & Dy203 & 1.15 & 20.65 & 0.01 & 1.00 & 20.65 & 0.01 & 1.00 & 20.65 & 0.01 \\
\hline $\mathrm{F}$ & 164.33 & F- & 1.00 & 164.33 & 0.09 & 0.73 & 119.96 & 0.07 & 1.00 & 119.96 & 0.08 \\
\hline $\mathrm{Fe}$ & \begin{tabular}{|l|}
46798.75 \\
\end{tabular} & $\mathrm{Fe} 2 \mathrm{O} 3$ & 1.43 & 66922.21 & 37.05 & 1.00 & 66922.21 & 38.69 & 1.00 & 66922.21 & 43.18 \\
\hline La & 1607.59 & $\mathrm{La203}$ & 1.17 & 1885.70 & 1.04 & 1.00 & 1885.70 & 1.09 & 1.00 & 1885.70 & 1.22 \\
\hline $\mathrm{Pb}$ & 392.97 & $\mathrm{PbO}$ & 1.08 & 423.23 & 0.23 & 1.00 & 423.23 & 0.24 & 1.00 & 423.23 & 0.27 \\
\hline $\mathrm{Li}$ & 10.43 & Li203 & 2.15 & 22.45 & 0.01 & 1.00 & 22.45 & 0.01 & 1.00 & 22.45 & 0.01 \\
\hline $\mathrm{Mg}$ & 339.38 & $\mathrm{MgO}$ & 1.66 & 562.69 & 0.31 & 1.00 & 562.69 & 0.33 & 1.00 & 562.69 & 0.36 \\
\hline $\mathrm{Mn}$ & 1028.86 & $\mathrm{MnO} 2$ & 1.58 & 1627.66 & 0.90 & 1.00 & 1627.66 & 0.94 & 1.00 & 1627.66 & 1.05 \\
\hline Mo & 16.79 & $\mathrm{MoO3}$ & 1.50 & 25.19 & 0.01 & 1.00 & 25.19 & 0.01 & 1.00 & 25.19 & 0.02 \\
\hline Nd & 1039.57 & $\mathrm{~N} 2 \mathrm{O} 3$ & 1.17 & 1213.18 & 0.67 & 1.00 & 1213.18 & 0.70 & 1.00 & 1213.18 & 0.78 \\
\hline $\mathrm{Ni}$ & 3165.17 & $\mathrm{NiO}$ & 1.27 & 4029.26 & 2.23 & 1.00 & 4029.26 & 2.33 & 1.00 & 4029.26 & 2.60 \\
\hline $\mathrm{P}$ & 349.03 & $\mathrm{P2O3}$ & 2.29 & 799.63 & 0.44 & 1.00 & 799.63 & 0.46 & 0.34 & 271.87 & 0.18 \\
\hline $\mathrm{Pu}$ & 21.29 & $\mathrm{PuO} 2$ & 1.13 & 27.19 & 0.02 & 1.00 & 27.19 & 0.02 & 1.00 & 27.19 & 0.02 \\
\hline $\mathrm{K}$ & 743.06 & $\mathrm{~K} 20$ & 1.21 & 895.39 & 0.50 & 1.00 & 895.39 & 0.52 & 1.00 & 895.39 & 0.58 \\
\hline $\mathrm{Re}$ & 25.93 & $\mathrm{Re} 2 \mathrm{O} 3$ & 1.13 & 29.27 & 0.02 & 1.00 & 29.27 & 0.02 & 1.00 & 29.27 & 0.02 \\
\hline Rh & 150.75 & $\mathrm{Rh} 2 \mathrm{O} 3$ & 1.23 & 185.87 & 0.10 & 1.00 & $\begin{array}{ll}185.87 \\
\end{array}$ & 0.11 & 1.00 & 185.87 & 0.12 \\
\hline $\mathrm{Ru}$ & 65.02 & $\mathrm{Ru203}$ & 1.23 & 79.97 & 0.04 & 1.00 & 79.97 & 0.05 & 1.00 & 79.97 & 0.05 \\
\hline Sb & 1218.20 & $\mathrm{Sb} 2 \mathrm{O} 3$ & 1.20 & 1458.19 & 0.81 & 1.00 & 1458.19 & 0.84 & 1.00 & 1458.19 & 0.94 \\
\hline $\mathrm{Se}$ & 367.96 & $\mathrm{SeO} 2$ & 1.41 & 516.98 & 0.29 & 1.00 & 516.98 & 0.30 & 1.00 & 516.98 & 0.33 \\
\hline $\mathrm{Si}$ & 1600.46 & $\mathrm{SiO}_{2}$ & 2.14 & 3423.38 & 1.90 & 1.00 & 3423.38 & 1.98 & 1.00 & 3423.38 & 2.21 \\
\hline $\mathrm{Ag}$ & 240.78 & Ag2O & 1.07 & 258.60 & 0.14 & 1.00 & 258.60 & 0.15 & 1.00 & 258.60 & 0.17 \\
\hline $\mathrm{Na}$ & 21113.03 & $\mathrm{Na} 2 \mathrm{O}$ & 1.35 & 28460.36 & 15.76 & 0.79 & 22341.39 & 12.91 & 1.00 & 22341.39 & 14.42 \\
\hline $\mathrm{Sr}$ & 116.81 & SrO & 1.18 & 138.19 & 0.08 & 1.00 & 138.19 & 0.08 & 1.00 & 138.19 & 0.09 \\
\hline 504 & 2336.36 & SO4 & 1.00 & 2336.36 & 1.29 & 0.44 & 1028.00 & 0.59 & 1.00 & 1028.00 & 0.66 \\
\hline $\mathrm{Te}$ & 123.24 & $\mathrm{TeO} 2$ & 1.25 & 154.42 & 0.09 & 1.00 & 154.42 & 0.09 & 1.00 & 154.42 & 0.10 \\
\hline Th & 173.98 & $\mathrm{ThO}_{2}$ & 1.14 & 197.99 & 0.11 & 1.00 & 197.99 & 0.11 & 1.00 & 197.99 & 0.13 \\
\hline $\mathrm{Ti}$ & 27.72 & $\mathrm{TiO} 2$ & 1.67 & 46.24 & 0.03 & 1.00 & 46.24 & 0.03 & 1.00 & 46.24 & 0.03 \\
\hline $\mathrm{TI}$ & 2993.69 & T1203 & 1.12 & 3343.95 & 1.85 & 1.00 & 3343.95 & 1.93 & 1.00 & 3343.95 & 2.16 \\
\hline $\mathrm{U}$ & 4501.25 & U308 & 1.18 & 5306.97 & 2.94 & 1.00 & 5306.97 & 3.07 & 1.00 & 5306.97 & 3.42 \\
\hline $\mathrm{V}$ & 11.64 & V205 & 1.79 & 20.78 & 0.01 & 1.00 & 20.78 & 0.01 & 1.00 & 20.78 & 0.01 \\
\hline $\mathrm{Zn}$ & 50.37 & $2 \mathrm{no}$ & 1.24 & 62.66 & 0.03 & 1.00 & 62.66 & 0.04 & 1.00 & 62.66 & 0.04 \\
\hline $\mathrm{Zr}$ & 6466.09 & $\mathrm{ZrO2}$ & 1.35 & 8729.22 & 4.83 & 1.00 & 8729.22 & 5.05 & 1.00 & 8729.22 & 5.63 \\
\hline Total catjon, $\mathrm{kg}$ & 25160.39 & Total & & 180612.34 & 100.00 & & 172989.35 & 100.00 & & 154971.18 & 100.00 \\
\hline $\begin{array}{l}\text { Total anions (NO2, } \\
\text { NO3, TJC as } \mathrm{CO} 3), \mathrm{kg}\end{array}$ & 41662.00 & & & & & & & & & & \\
\hline Water. kg & 253047.00 & & & & & & & & & & \\
\hline
\end{tabular}




\section{WHC-SD-WM-TI-768}

Revision 0

Table 3-2. Tank 241-AZ-102 Waste Composition. (2 sheets)

\begin{tabular}{|c|c|c|c|c|c|c|c|c|c|c|c|}
\hline Element & $\begin{array}{l}\text { Element } \\
\text { wt kg }\end{array}$ & Oxide & $\begin{array}{l}\text { Oxide } \\
\text { factor }\end{array}$ & $\begin{array}{c}\text { Oxide wt } \\
\mathrm{kg}\end{array}$ & $\begin{array}{l}\text { Oxide } \\
\text { wt\% }\end{array}$ & $\begin{array}{l}\text { Water } \\
\text { wash } \\
\text { factor }\end{array}$ & $\begin{array}{l}\text { Water wash } \\
\text { solids, } \mathrm{kg}\end{array}$ & $\begin{array}{l}\text { Water } \\
\text { wash } \\
\text { solids, } \\
\text { w1\% }\end{array}$ & $\begin{array}{l}\text { Caustic } \\
\text { wash } \\
\text { factor }\end{array}$ & \begin{tabular}{|c|}
$\begin{array}{c}\text { Caustic } \\
\text { wash } \\
\text { solids, kg }\end{array}$ \\
\end{tabular} & $\begin{array}{l}\text { Caustic } \\
\text { wash } \\
\text { solids. } \\
\text { wt\% }\end{array}$ \\
\hline $\begin{array}{l}\text { Tot.Siudg,kg } \\
\text { (den }=1.49 \mathrm{~kg} / 1,51 \% \\
\text { water }\end{array}$ & 419869.39 & & & & & & & & & & \\
\hline $\begin{array}{l}\text { Total estimated sludge. } \\
\mathrm{kg}\end{array}$ & 196170.00 & & & & & & & & & & \\
\hline Mass Bal.\% & 84.62 & & & & & & & & & & \\
\hline & & & & & & & & & & & \\
\hline
\end{tabular}


WHC-SD-WM-TI-768

Revision 0

Table 3-3. Tank 241-AY-102 Waste Composition. (2 sheets)

\begin{tabular}{|c|c|c|c|c|c|c|c|c|c|c|c|}
\hline Element & $\begin{array}{c}\text { Element wt } \\
\mathrm{kg}\end{array}$ & Oxide & $\begin{array}{l}\text { Oxide } \\
\text { factor }\end{array}$ & $\begin{array}{c}\text { Oxide } \\
\text { wt. } \\
\text { kg }\end{array}$ & $\begin{array}{l}\text { Oxide } \\
w \pi x\end{array}$ & $\begin{array}{l}\text { Water } \\
\text { wash } \\
\text { factor }\end{array}$ & $\begin{array}{c}\text { Water } \\
\text { wash } \\
\text { solids, } \mathbf{k g}\end{array}$ & $\begin{array}{c}\text { Water } \\
\text { wash } \\
\text { solids, } \\
\text { wt\% }\end{array}$ & $\begin{array}{c}\text { Caustic } \\
\text { wash } \\
\text { factor }\end{array}$ & $\begin{array}{c}\text { Caustic } \\
\text { wash } \\
\text { solids, } \\
\text { kg }\end{array}$ & $\begin{array}{l}\text { Caustic } \\
\text { wash } \\
\text { solids, } \\
\text { wt\% }\end{array}$ \\
\hline Al & 2919.00 & $\mathrm{Al} 2 \mathrm{O} 3$ & 1.89 & 5513.99 & 17.42 & 1.00 & 5513.99 & 17.42 & 0.52 & 2867.28 & 10.15 \\
\hline As & 0.00 & As2O3 & 1.32 & 0.00 & 0.00 & 1.00 & 0.00 & 0.00 & 1.00 & 0.00 & 0.00 \\
\hline $\mathrm{Ba}$ & 153.72 & $\mathrm{BaO}$ & 1.12 & 171.55 & 0.54 & 1.00 & 171.55 & 0.54 & 1.00 & 171.55 & 0.61 \\
\hline $\mathrm{Be}$ & 0.00 & $\mathrm{BeO}$ & 2.78 & 0.00 & 0.00 & 1.00 & 0.00 & 0.00 & 1.00 & 0.00 & 0.00 \\
\hline B & 213.97 & $\mathrm{~B} 2 \mathrm{O} 3$ & 3.21 & 686.20 & 2.17 & 1.00 & 686.20 & 2.17 & 1.00 & 686.20 & 2.43 \\
\hline $\mathrm{Ca}$ & 1081.50 & $\mathrm{CaO}$ & 1.40 & 1513.02 & 4.78 & 1.00 & 1513.02 & 4.78 & 1.00 & 1513.02 & 5.35 \\
\hline $\mathrm{Cd}$ & 32.00 & $\mathrm{CdO}$ & 1.14 & 36.54 & 0.12 & 1.00 & 36.54 & 0.12 & 1.00 & 36.54 & 0.13 \\
\hline $\mathrm{Ce}$ & 85.70 & $\mathrm{CeO} 2$ & 1.23 & 105.24 & 0.33 & 1.00 & 105.24 & 0.33 & 1.00 & 105.24 & 0.37 \\
\hline $\mathrm{Cl}$ & 644.23 & $\mathrm{Cl}-$ & 1.00 & 644.23 & 2.04 & 1.00 & 644.23 & 2.04 & 1.00 & 644.23 & 2.28 \\
\hline $\mathrm{Cr}$ & 271.13 & $\mathrm{Cr} 2 \mathrm{O} 3$ & 1.46 & 396.12 & 1.25 & 1.00 & 396.12 & 1.25 & 0.89 & 352.55 & 1.25 \\
\hline $\mathrm{Co}$ & 0.00 & $\mathrm{Co} 2 \mathrm{O} 3$ & 1.41 & 0.00 & 0.00 & 1.00 & 0.00 & 0.00 & 1.00 & 0.00 & 0.00 \\
\hline $\mathrm{Cu}$ & 0.00 & CuO & 1.25 & 0.00 & 0.00 & 1.00 & 0.00 & 0.00 & 1.00 & 0.00 & 0.00 \\
\hline Dy & 0.00 & Dy203 & 1.15 & 0.00 & 0.00 & 1.00 & 0.00 & 0.00 & 1.00 & 0.00 & 0.00 \\
\hline $\mathrm{F}$ & 655.82 & F- & 1.00 & 655.82 & 2.07 & 1.00 & 655.82 & 2.07 & 1.00 & 655.82 & 2.32 \\
\hline $\mathrm{Fe}$ & 6465.40 & $\mathrm{Fe} 2 \mathrm{O} 3$ & 1.43 & 9245.52 & 29.21 & 1.00 & 9245.52 & 29.21 & 1.00 & 9245.52 & 32.72 \\
\hline La & 305.90 & $\mathrm{La} 203$ & 1.17 & 358.82 & 1.13 & 1.00 & 358.82 & 1.13 & 1.00 & 358.82 & 1.27 \\
\hline $\mathrm{Pb}$ & 0.00 & $\mathrm{PbO}$ & 1.08 & 0.00 & 0.00 & 1.00 & 0.00 & 0.00 & 1.00 & 0.00 & 0.00 \\
\hline$\underline{L i}$ & 0.00 & $\mathrm{Li} 203$ & 2.15 & 0.00 & 0.00 & 1.00 & 0.00 & 0.00 & 1.00 & 0.00 & 0.00 \\
\hline $\mathrm{Mg}$ & 525.20 & $\mathrm{MgO}$ & 1.66 & 870.78 & 2.75 & 1.00 & 870.78 & 2.75 & 1.00 & 870.78 & 3.08 \\
\hline Mn & 678.20 & $\mathrm{MnO} 2$ & 1.58 & 1072.91 & 3.39 & 1.00 & 1072.91 & 3.39 & 1.00 & 1072.91 & 3.80 \\
\hline Mo & 10.60 & $\mathrm{MoO} 3$ & 1.50 & 15.90 & 0.05 & 1.00 & 15.90 & 0.05 & 1.00 & 15.90 & 0.06 \\
\hline $\mathrm{Nd}$ & 205.40 & $\mathrm{Nd} 2 \mathrm{O} 3$ & 1.17 & 239.70 & 0.76 & 1.00 & 239.70 & 0.76 & 1.00 & 239.70 & 0.85 \\
\hline $\mathrm{Ni}$ & 233.20 & $\mathrm{NiO}$ & 1.27 & 296.86 & 0.94 & 1.00 & 296.86 & 0.94 & 1.00 & 296.86 & 1.05 \\
\hline $\mathbf{P}$ & 461.70 & $\mathrm{P} 2 \mathrm{O} 3$ & 2.29 & 1057.75 & 3.34 & 1.00 & 1057.75 & 3.34 & 0.34 & 359.64 & 1.27 \\
\hline $\mathrm{Pu}$ & 3.06 & $\mathrm{PuO} 2$ & 1.13 & 86.87 & 0.27 & 1.00 & 86.87 & 0.27 & 1.00 & 86.87 & 0.31 \\
\hline $\mathrm{K}$ & 134.40 & $\mathrm{~K} 2 \mathrm{O}$ & 1.21 & 161.95 & 0.51 & 1.00 & 161.95 & 0.51 & 1.00 & 161.95 & 0.57 \\
\hline $\mathrm{Re}$ & 0.00 & $\mathrm{Re} 2 \mathrm{O}_{3}$ & 1.13 & 0.00 & 0.00 & 1.00 & 0.00 & 0.00 & 1.00 & 0.00 & 0.00 \\
\hline $\mathrm{Rh}$ & 0.00 & $\mathrm{Rh} 2 \mathrm{O} 3$ & 1.23 & 0.00 & 0.00 & 1.00 & 0.00 & 0.00 & 1.00 & 0.00 & 0.00 \\
\hline $\mathrm{Ru}$ & 0.00 & $\mathrm{Ru} 2 \mathrm{O} 3$ & 1.23 & 0.00 & 0.00 & 1.00 & 0.00 & 0.00 & 1.00 & 0.00 & 0.00 \\
\hline $\mathrm{Sb}$ & 0.00 & $\mathrm{Sb} 203$ & 1.20 & 0.00 & 0.00 & 1.00 & 0.00 & 0.00 & 1.00 & 0.00 & 0.00 \\
\hline Se & 0.00 & $\mathrm{SeO} 2$ & 1.41 & 0.00 & 0.00 & 1.00 & 0.00 & 0.00 & 1.00 & 0.00 & 0.00 \\
\hline Si & 934.68 & $\mathrm{SiO} 2$ & 2.14 & 1999.28 & 6.32 & 1.00 & 1999.28 & 6.32 & 1.00 & 1999.28 & 7.08 \\
\hline $\mathrm{Ag}$ & 559.20 & Ag2O & 1.07 & 600.58 & 1.90 & 1.00 & 600.58 & 1.90 & 1.00 & 600.58 & 2.13 \\
\hline $\mathrm{Na}$ & 3198,00 & $\mathrm{Na} 2 \mathrm{O}$ & 1.35 & 4310.90 & 13.62 & 1.00 & 4310.90 & 13.62 & 1.00 & 4310.90 & 15.26 \\
\hline Sr & 12.23 & SrO & 1.18 & 14.47 & 0.05 & 1.00 & 14.47 & 0.05 & 1.00 & 14.47 & 0.05 \\
\hline SO4 & 47.50 & $\mathrm{SO4}$ & 1.00 & 47.50 & 0.15 & 1.00 & 47.50 & 0.15 & 1.00 & 47.50 & 0.17 \\
\hline Te & 38.70 & $\mathrm{TeO} 2$ & 1.25 & 48.49 & 0.15 & 1.00 & 48.49 & 0.15 & 1.00 & 48.49 & 0.17 \\
\hline Th & 0.00 & ThO2 & 1.14 & 0.00 & 0.00 & 1.00 & 0.00 & 0.00 & 1.00 & 0.00 & 0.00 \\
\hline $\mathrm{Ti}$ & 26.40 & $\mathrm{TiO}_{2}$ & 1.67 & 44.04 & 0.14 & 1.00 & 44.04 & 0.14 & 1.00 & 44.04 & 0.16 \\
\hline
\end{tabular}




\begin{tabular}{|c|c|c|c|c|c|c|c|c|c|c|c|}
\hline & & & & & & & & & & $\begin{array}{c}\operatorname{xosp}^{\prime} \hat{H}_{\mathrm{H}} \\
\text { "xO }\end{array}$ & :ลิบ!̣s!W \\
\hline & & & & & & & & & & $\varepsilon 0^{\circ} 0 L$ & \% 'כourjeq ssew \\
\hline & & & & & & & & & & $00.00+691$ & 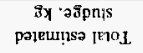 \\
\hline & & & & & & & & & & $09^{\circ}+89811$ & 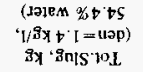 \\
\hline & & & & & & & & & & 09.รऽIZ6 & BX - Iale \\
\hline & & & & & & & & & & $00 ' 88 \circ \varepsilon$ & 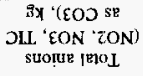 \\
\hline $0000 \mathrm{I}$ & EI $8 \subseteq 28 z$ & & $00.00 \mathrm{I}$ & tS.9b9IE & & 00.001 & tS'9๑9IE & & I810L & 85.61112 & 9x 'uopes \\
\hline $12 \%$ & $t 6.65$ & $00^{\circ} \mathrm{I}$ & 610 & $\nabla 6.6 S$ & 00.1 & 610 & $\$ 6.65$ & SE'T & zorZ & 00 & $\mathrm{JZ}$ \\
\hline SIO & $99^{\circ} \varepsilon$ & 00.1 & $\$ 10$ & $99^{\circ} \varepsilon$ & $00^{\circ} \mathrm{I}$ & $\$ 10$ & $99^{\circ}$ Et & $+2 \div$ & O"Z & $0[S E$ & $\mathrm{IZ}_{\mathrm{Z}}$ \\
\hline $00 \%$ & 000 & $00 \%$ & $00 \%$ & 000 & $00 \% \mathrm{I}$ & $00^{\circ} 0$ & $00^{\circ} 0$ & $6 L^{\prime} !$ & sozA & $00 \%$ & $\Lambda$ \\
\hline$\angle L D$ & $88 \angle \neg \varepsilon I$ & 001 & $9 z+5$ & $88^{\circ} \angle t \varepsilon I$ & $00^{\circ} \mathrm{I}$ & $92 t$ & $88 \angle \forall E I$ & $8 I^{\circ} 1$ & gokn & $\downarrow Z \varepsilon \mapsto I I$ & n \\
\hline 000 & $00 \%$ & $00^{\circ} \mathrm{I}$ & 000 & 000 & 001 & 000 & $00^{\circ} 0$ & ZI'T & EOZLL & 000 & LL \\
\hline 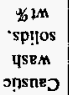 & $\begin{array}{c}\text { 8y } \\
\text { sptyos } \\
\text { पsem } \\
\text { ṣsneว }\end{array}$ & $\begin{array}{l}\text { IOTJEI } \\
\text { पsem } \\
\text { ọ̣sneכ }\end{array}$ & 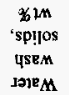 & $\begin{array}{l}\text { क̊X 'sp!jos } \\
\text { USEM } \\
\text { JOIEM }\end{array}$ & $\begin{array}{l}\text { JOPRI } \\
\text { USEM } \\
\text { JPIEM }\end{array}$ & $\begin{array}{c}\text { \%in } \\
\text { әp!xo }\end{array}$ & $\begin{array}{c}8 x \\
\text { optx } \\
\text { opto }\end{array}$ & $\begin{array}{l}\text { IOIJW } \\
\text { כptxO }\end{array}$ & aptxo & $\begin{array}{c}\text { 8x } \\
\text { in tuaturg }\end{array}$ & 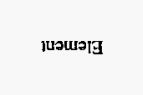 \\
\hline
\end{tabular}

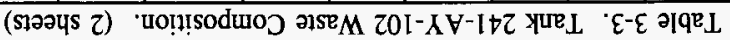

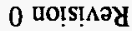


WHC-SD-WM-TI-768

Revision 0

Table 3-4. Tank 241-C-106 Waste Composition. (2 sheets)

\begin{tabular}{|c|c|c|c|c|c|c|c|c|c|c|c|}
\hline Element & $\begin{array}{c}\text { Element wt } \\
\mathrm{kg}\end{array}$ & Oxide & $\begin{array}{l}\text { Oxide } \\
\text { factor }\end{array}$ & Oxide $w \mathbf{k g}$ & $\begin{array}{c}\text { Oxide } \\
\text { wr\% }\end{array}$ & $\begin{array}{c}\text { Water } \\
\text { wash } \\
\text { factor }\end{array}$ & $\begin{array}{c}\text { Water wash } \\
\text { solids, } \mathbf{k g}\end{array}$ & $\begin{array}{c}\text { Water } \\
\text { wash } \\
\text { solids, } \\
\text { wi\% }\end{array}$ & $\begin{array}{l}\text { Caustic } \\
\text { wash } \\
\text { factor }\end{array}$ & $\begin{array}{c}\text { Caustic } \\
\text { wash } \\
\text { solids, kg }\end{array}$ & $\begin{array}{c}\text { Caustic } \\
\text { wash } \\
\text { solids, } \\
\text { wt\% }\end{array}$ \\
\hline Al & 43633.50 & $\mathrm{Al} 203$ & 1.89 & 82423.68 & 14.87 & 1.00 & 82382.47 & 16.97 & 0.52 & 42838.88 & 9.70 \\
\hline As & 0.00 & As203 & 1.32 & 0.00 & 0.00 & 1.00 & 0.00 & 0.00 & 1.00 & 0.00 & 0.00 \\
\hline $\mathrm{Ba}$ & 5209.70 & $\mathrm{BaO}$ & 1.12 & 5814.03 & 1.05 & 1.00 & 5810.54 & 1.20 & 1.00 & 5810.54 & 1.32 \\
\hline $\mathrm{Bi}$ & 533.90 & Bi203 & 1.12 & 595.30 & 0.11 & 0.97 & -577.44 & 0.12 & +.00 & 577.44 & 0.13 \\
\hline$B$ & 20.80 & $\mathrm{~B} 2 \mathrm{O} 3$ & 3.21 & 66.71 & 0.01 & 0.76 & 50.39 & 0.01 & 1.00 & 50.39 & 0.01 \\
\hline $\mathrm{Ca}$ & 12714.90 & $\mathrm{CaO}$ & 1.40 & 17788.15 & 3.21 & 1.00 & 17720.55 & 3.65 & 1.00 & 17720.55 & 4.01 \\
\hline $\mathrm{Cd}$ & 394.50 & $\mathrm{CdO}$ & 1.14 & 450.52 & 0.08 & 0.97 & 435.92 & 0.09 & 1.00 & 435.92 & 0.10 \\
\hline $\mathrm{Ce}$ & 0.00 & $\mathrm{CeO} 2$ & 1.23 & 0.00 & 0.00 & 1.00 & 0.00 & 0.00 & 1.00 & 0.00 & 0.00 \\
\hline Cl & 0.00 & $\mathrm{Cl}-$ & 1.00 & 0.00 & 0.00 & 0.60 & 0.00 & 0.00 & 1.00 & 0.00 & 0.00 \\
\hline $\mathrm{Cr}$ & 1049.70 & $\mathrm{Cr} 203$ & 1.46 & 1533.61 & 0.28 & 1.00 & 1531.46 & 0.32 & 0.89 & 1363.00 & 0.31 \\
\hline Co & 5.10 & $\mathrm{Co} 203$ & 1.41 & 7.18 & 0.00 & 1.00 & 7.18 & 0.00 & 1.00 & 7.18 & 0.00 \\
\hline $\mathrm{Cu}$ & 136.50 & $\mathrm{CuO}$ & 1.25 & 170.90 & 0.03 & 0.99 & 168.86 & 0.03 & 1.00 & 168.86 & 0.04 \\
\hline Dy & 0.00 & Dy2O3 & 1.15 & 0.00 & 0.00 & 1.00 & 0.00 & 0.00 & 1.00 & 0.00 & 0.00 \\
\hline $\mathrm{F}$ & 492.62 & F- & 1.00 & 492.62 & 0.09 & 0.73 & 359.61 & 0.07 & 1.00 & 359.61 & 0.08 \\
\hline $\mathrm{Fe}$ & 55511.30 & $\mathrm{Fe} 203$ & 1.43 & 79381.16 & 14.33 & 1.00 & 79381.16 & 16.35 & 1.00 & 79381.16 & 17.97 \\
\hline $\mathrm{La}$ & 0.00 & $\mathrm{La} 203$ & 1.17 & 0.00 & 0.00 & 1.00 & 0.00 & 0.00 & 1.00 & 0.00 & 0.00 \\
\hline $\mathrm{Pb}$ & 2564.30 & $\mathrm{PbO}$ & 1.08 & 2761.75 & 0.50 & 0.98 & 2710.11 & 0.56 & 1.00 & 2710.11 & 0.61 \\
\hline $\mathrm{Li}$ & 0.00 & $\mathrm{Li} 203$ & 2.15 & 0.00 & 0.00 & 1.00 & 0.00 & 0.00 & 1.00 & 0.00 & 0.00 \\
\hline $\mathrm{Mg}$ & 6994.10 & $\mathrm{MgO}$ & 1.66 & 11596.22 & 2.09 & 1.00 & 11596.22 & 2.39 & 1.00 & 11596.22 & 2.62 \\
\hline Mn & 1962.90 & $\mathrm{MnO} 2$ & 1.58 & 3105.31 & 0.56 & 1.00 & 3105.31 & 0.64 & 1.00 & 3105.31 & 0.70 \\
\hline Mo & 0.00 & $\mathrm{MoO} 3$ & 1.50 & 0.00 & 0.00 & 1.00 & 0.00 & 0.00 & 1.00 & 0.00 & 0.00 \\
\hline $\mathrm{Nd}$ (Hara) & 283.62 & $\mathrm{Nd} 2 \mathrm{O} 3$ & 1.17 & 330.98 & 0.06 & 1.00 & 330.98 & 0.07 & 1.00 & 330.98 & 0.07 \\
\hline $\mathrm{Ni}$ & 1037.70 & $\mathrm{NiO}$ & 1.27 & 1320.99 & 0.24 & 0.97 & 1277.27 & 0.26 & 1.00 & 1277.27 & 0.29 \\
\hline $\mathrm{P}$ & 3102.85 & $\mathrm{P} 203$ & 2.29 & 7108.63 & 1.28 & 0.85 & 6033.80 & 1.24 & 0.34 & 2051.49 & 0.46 \\
\hline Pu & 88.22 & PuO2 & 1.13 & 99.78 & 0.02 & 1.00 & 99.78 & 0.02 & 1.00 & 99.78 & 0.02 \\
\hline $\mathbf{K}$ & 1572.80 & $\mathbf{K} 20$ & 1.21 & 1895.22 & 0.34 & 0.89 & 1695.47 & 0.35 & 1.00 & 1695.47 & 0.38 \\
\hline $\mathrm{Re}$ & 0.00 & $\mathrm{Re} 2 \mathrm{O} 3$ & 1.13 & 0.00 & 0.00 & 1.00 & 0.00 & 0.00 & 1.00 & 0.00 & 0.00 \\
\hline $\mathrm{Rh}$ & 0.00 & $\mathrm{Rh} 203$ & 1.23 & 0.00 & 0.00 & 1.00 & 0.00 & 0.00 & 1.00 & 0.00 & 0.00 \\
\hline $\mathrm{Ru}$ & 0.29 & $\mathrm{R} w 203$ & 1.23 & 0.35 & 0.00 & 1.00 & 0.35 & 0.00 & 1.00 & 0.35 & 0.00 \\
\hline $\mathrm{Sb}$ & 0.00 & $\mathrm{Sb} 2 \mathrm{O} 3$ & 1.20 & 0.00 & 0.00 & 1.00 & 0.00 & 0.00 & 1.00 & 0.00 & 0.00 \\
\hline $\mathrm{Se}$ & 0.00 & $\mathrm{SeO} 2$ & 1.41 & 0.00 & 0.00 & 1.00 & 0.00 & 0.00 & 1.00 & 0.00 & 0.00 \\
\hline $\mathrm{Si}$ & 75717.80 & $\mathrm{SiO} 2$ & 2.14 & 161960.37 & 29.23 & 1.00 & 161960.37 & 33,36 & 1.00 & 161960.37 & 36.66 \\
\hline
\end{tabular}




\begin{tabular}{|c|c|c|c|c|c|c|c|c|c|c|c|}
\hline & & & & & & & & & & $\operatorname{xosp} \kappa_{H} \cdot x_{O}$ & : ถึบ!ss!W \\
\hline & & & & & & & & & & $68: 26$ & みleg SseW \\
\hline & & & & & & & & & & $00^{\circ} Z L Z 9901$ & $5 x+1 \$ \mathrm{G}$ XIE $\mathrm{L}$ \\
\hline & & & & & & & & & & $06 \_97066$ & $8 x^{\circ} 8 \mathrm{pIS}[\mathrm{E}] \mathrm{C}_{1}$ \\
\hline & & & & & & & & & & $0 \mathcal{E}$ โ9685 & 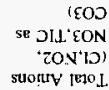 \\
\hline & & & & & & & & & & $00 \angle 88 \angle Z$ & $\begin{array}{r}\text { (Uorsny) } \\
\text { spilos }\end{array}$ \\
\hline & & & & & & & & & & $00^{\circ} Z 6 L 6 S S$ & I2) $M$ \\
\hline $00^{\circ} 00 \mathrm{I}$ & to s $^{\circ} \mathrm{s} 281 \mathrm{th}$ & & 00.001 & 06.615580 & & $0000 \mathrm{I}$ & $z 9$ sIItss & & $x_{O}$ 成O & $09^{\circ} \mathcal{E} Z 8 E t \varepsilon$ & L \\
\hline$\angle 9^{\circ} 0$ & It'9S6z & 00.1 & $19 \%$ & It'9S6Z & 560 & $95^{\circ} 0$ & I6.8IIE & SE'I & $z O^{J} \mathrm{Z}$ & 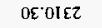 & ${ }^{\mathrm{J}} \mathrm{Z}$ \\
\hline 100 & St' $[9$ & 001 & 100 & 50.19 & $00^{\circ} \mathrm{I}$ & $10 \%$ & $\$ \nabla \cdot 19$ & $t z \cdot 1$ & ouz & $0 t^{\prime} 6 t$ & $\mathbf{u}_{\mathrm{Z}}$ \\
\hline $00 \%$ & $00^{\circ} 0$ & $00^{\prime} \mathrm{I}$ & $\infty 0^{\circ}$ & $00^{\circ} 0$ & $00^{\prime} \mathrm{I}$ & $00^{\circ} 0$ & $00^{\circ} 0$ & $6 L^{\prime} 1$ & $S O Z \Lambda$ & $00^{\circ} 0$ & $\Lambda$ \\
\hline $\mathrm{II} 0$ & $85^{\prime} \mathrm{ZOS}$ & $\infty 0^{\prime} 1$ & or'o & $85 \cdot 205$ & $86^{\circ} 0$ & $60^{\circ} 0$ & to.toIs & $81^{\circ} 1$ & $805 n$ & $00^{\circ} 9 \mathrm{ED}$ & n \\
\hline $00 \%$ & 000 & $00 \mathrm{I}$ & 000 & $00^{\circ} 0$ & $00^{\circ} \mathrm{I}$ & 000 & $00^{\circ}$ & $Z \mathrm{ZI} I$ & EOZLL & 000 & $\mathrm{LL}$ \\
\hline $00^{\circ} 0$ & $00^{\circ} 0$ & $00^{\circ} \mathrm{I}$ & $00 \%$ & $00^{\circ} 0$ & $00^{\prime} \mathrm{I}$ & 000 & 000 & $\angle 9.1$ & zo!L & 000 & I.I. \\
\hline $00^{\circ} 0$ & $00^{\circ} 0$ & $00^{\prime} \mathrm{I}$ & $00^{\circ} 0$ & $00^{\circ} 0$ & $00^{\prime} \mathbf{I}$ & $00^{\prime} 0$ & $00^{\circ} 0$ & $t I^{-} I$ & $204 \perp$ & 000 & 4. \\
\hline $00 \%$ & $00^{\circ} 0$ & $00 . I$ & $00 \%$ & $00^{\circ} 0$ & 00 I I & 00.0 & 00.0 & St'I & $20^{\circ} \mathrm{L}$ & $00 \%$ & $\partial \mathrm{I}$ \\
\hline$t 20$ & $280801^{-}$ & $-00 \mathrm{I}$ & $2 z 0$ & -280801 & $\omega 0$ & $\omega 0$ & $0095+2$ & $00^{\circ} \mathrm{I}$ & tos & $0 \nabla^{\circ} 95 \nabla \tau$ & tos \\
\hline $\mathfrak{E} 0^{\circ} 0$ & $68.6 \mathrm{ZI}$ & $00^{\prime} \mathrm{I}$ & $50^{\circ} 0$ & 68.621 & $00^{\prime} I$ & 200 & $68^{\circ} 621$ & 811 & ous & $08^{\circ} 60 \mathrm{I}$ & IS \\
\hline O६ $\varepsilon \tau$ & $168+620 I$ & $00 \mathrm{I}$ & $0 z I z$ & It' $8+6201$ & 19.0 & $8 \varepsilon^{\prime} 0 \mathcal{E}$ & $8 \varepsilon^{\prime} 92589 \mathrm{I}$ & \Е'। & OZN & $0 \tau^{*} \mid \angle 8 \nabla z I$ & EN \\
\hline tio & 60.509 & 001 & 210 & $60 ऽ 09$ & $00^{\prime} \mathbf{I}$ & $t 50$ & $60^{\circ} \varsigma 09$ & $\angle 01$ & otov & $0)^{\circ} \varepsilon 9 S$ & :V \\
\hline $\begin{array}{l}\text { \%1m } \\
\text { 'sp!jos } \\
\text { ysem } \\
\text { ọsnes }\end{array}$ & 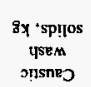 & $\begin{array}{c}\text { 10ю5ey } \\
\text { पsem } \\
\text { op̣sne? }\end{array}$ & $\begin{array}{l}\text { \%lM } \\
\text { 'sp!jos } \\
\text { 4sem } \\
\text { INEM }\end{array}$ & 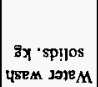 & $\begin{array}{l}\text { Jo10e] } \\
\text { YseM } \\
\text { J010 M }\end{array}$ & $\begin{array}{c}\text { \%1m } \\
\text { 2p!xo }\end{array}$ & 8x $1 \mathrm{~m}$ әргхо & $\begin{array}{l}\text { Ioporj } \\
\text { शp!xo }\end{array}$ & aptxo & 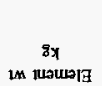 & 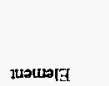 \\
\hline
\end{tabular}

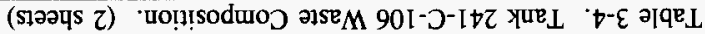




\subsection{NOMINAL BLEND COMPOSITION}

A nominal feed composition was developed for glass formulation purposes. This blend consists of 80 percent of the wastes in Tanks 241-AZ-101 and 241-AZ-102, 37 percent of the waste in Tank 241-C-106, and 15 percent of the waste in Tank 241-AY-102. The applicable sludge washing factors were estimated from the mass weighted average for each analyte in the nominal waste. Waste inventory estimates for this blend are presented in Table 3-5. This table also provides the estimated concentration of each component based on a concentration of $31 \mathrm{~g} / \mathrm{L}$ washed oxide in the nominal feed. Since the water washed feed will be stored for an indeterminate amount of time, a small amount of sodium. nitrite must be added to the waste for corrosion protection of the tanks. The amount of nitrite added (as $\mathrm{NaNO}_{2}$ ) is approximately equal to $3 \mathrm{~g} / 100 \mathrm{~g}$ of waste oxide or $0.93 \mathrm{~g} / \mathrm{L} \mathrm{NO}_{2}$ to the water washed sludge.

Table 3-5. Nominal Blend Composition.

$\left(0.8 * \mathrm{AZ}-101+0.8 * \mathrm{AZ}-102+0.37{ }^{*} \mathrm{C}-106\right.$ (Weiss) $\left.+0.15 * \mathrm{AY}-102\right)$

\begin{tabular}{|c|c|c|c|c|c|c|c|c|c|c|c|c|c|c|}
\hline Element & $\begin{array}{c}\text { Element } \\
\text { wt kg }\end{array}$ & Oxide & $\begin{array}{l}\text { Oxide } \\
\text { factor }\end{array}$ & $\begin{array}{c}\text { Oxide wt } \\
\mathrm{kg}\end{array}$ & $\begin{array}{c}\text { Oxide } \\
w t \%\end{array}$ & $\begin{array}{c}\text { Water } \\
\text { wash } \\
\text { factor }\end{array}$ & $\begin{array}{c}\text { Water } \\
\text { wash } \\
\text { solids, } \mathrm{kg}\end{array}$ & $\begin{array}{l}\text { Water } \\
\text { wash } \\
\text { solid, } \\
\text { wt } \%\end{array}$ & $\begin{array}{c}\text { Water } \\
\text { wash } \\
\text { solids } \\
\text { concen- } \\
\text { tration, } \\
\text { g/L }\end{array}$ & $\begin{array}{c}\text { Caustic } \\
\text { wash } \\
\text { factor }\end{array}$ & $\begin{array}{c}\text { Caustic } \\
\text { wash } \\
\text { solids, } \mathrm{kg}\end{array}$ & $\begin{array}{c}\text { Caustic } \\
\text { wash } \\
\text { solids, } \\
\text { wt\% }\end{array}$ & $\begin{array}{l}\text { Caustic } \\
\text { wash } \\
\text { solids } \\
\text { concen- } \\
\text { tration, } \\
\mathrm{g} / \mathrm{L}\end{array}$ & $\begin{array}{c}\text { Water } \\
\text { wash } \\
\text { conc., } \\
\text { g/L } \\
\text { (element } \\
\text { basis) }\end{array}$ \\
\hline Al & 39651.80 & $\mathrm{Al} 2 \mathrm{O} 3$ & 1.89 & 74902.25 & 16.95 & 1.00 & 74902.25 & 18.90 & 5.86 & 0.52 & 38949.17 & 10.90 & 3.38 & 3.10 \\
\hline As & 245.30 & As 203 & 1.32 & 323.80 & 0.07 & 1.00 & 323.80 & 0.08 & 0.03 & 1.00 & 323.80 & 0.09 & 0.03 & 0.02 \\
\hline $\mathrm{Ba}$ & 2217.60 & $\mathrm{BaO}$ & 1.12 & 2474.84 & 0.56 & 1.00 & 2474.84 & 0.62 & 0.19 & 1.00 & 2474.84 & 0.69 & 0.21 & 0.17 \\
\hline $\mathrm{Be}$ & 6.46 & $\mathrm{BeO}$ & 2.78 & 17,93 & 0.00 & 1.00 & 17.93 & 0.00 & 0.00 & 1.00 & 17.93 & 0.01 & 0.00 & 0.00 \\
\hline $\mathrm{Bi}$ & 197.50 & $\mathrm{Bi2O} 3$ & 1.12 & 221.20 & 0.05 & 0.97 & 214.56 & 0,05 & 0.02 & 1.00 & 214.56 & 0.06 & 0.02 & 0.01 \\
\hline$B$ & 210.40 & $\mathrm{~B}_{2} \mathrm{O}^{3}$ & 3.21 & 674.75 & 0.15 & 1.00 & 674.75 & 0.17 & 0.05 & 1.00 & 674.75 & 0.19 & 0.06 & 0.02 \\
\hline $\mathrm{Ca}$ & 5994.10 & $\mathrm{CaO}$ & 1.40 & 8385.75 & 1.90 & 1.00 & 8385.75 & 2.12 & 0.66 & 1.00 & 8385.75 & 2.35 & 0.73 & 0.47 \\
\hline Cd & 4689.40 & $\mathrm{CdO}$ & 1.14 & 5355.29 & 1.21 & 1.00 & 5355.29 & 1.35 & 0.42 & 1.00 & 5355.29 & 1.50 & 0.46 & 0.37 \\
\hline $\mathrm{Ce}$ & 428.20 & $\mathrm{CeO}$ & 1.23 & 525.83 & 0,12 & 1.00 & 525.83 & 0.13 & 0.04 & 1.00 & 525.83 & 0.15 & 0.05 & 0.03 \\
\hline Cl & 151.87 & $\mathrm{Cl}-$ & 1.00 & 151.87 & 0.03 & 0.64 & 97.20 & 0.02 & 0.01 & 1.00 & 97.20 & 0.03 & 0.01 & 0.01 \\
\hline $\mathrm{Cr}$ & 1189.50 & $\mathrm{Cr} 2 \mathrm{O} 3$ & 1.46 & 1737.86 & 0.39 & 0.87 & 1506.72 & 0.38 & 0.12 & 0.89 & 1340.98 & 0.38 & 0.12 & 0.08 \\
\hline $\mathrm{Co}$ & 564.20 & $\mathrm{Co} 203$ & 1.41 & 793.83 & 0.18 & 1.00 & 793.83 & 0.20 & 0.06 & 1.00 & 793.83 & 0.22 & 0.07 & 0.04 \\
\hline $\mathrm{Cu}$ & 214.80 & $\mathrm{CuO}$ & 1.25 & 268.93 & 0.06 & 1.00 & 268.93 & 0.07 & 0.02 & 1.00 & 268.93 & 0.08 & 0.02 & 0.02 \\
\hline Dy & 27.90 & Dy203 & 1.15 & 32.00 & 0.01 & 1.00 & 32.00 & 0.01 & 0.00 & 1.00 & 32.00 & $0.0 \mathrm{t}$ & 0.00 & 0.00 \\
\hline$F$ & 924.10 & F. & 1.00 & 924.10 & 0.21 & 0.62 & 572.94 & 0.14 & 0.04 & 1.00 & 572.94 & 0.16 & 0.05 & 0.04 \\
\hline $\mathrm{Fe}$ & 70937.50 & $\mathrm{Fe} 2 \mathrm{O} 3$ & 1.43 & 101440.63 & 22.96 & 1.00 & 101440.63 & 25.59 & 7.94 & 1.00 & 101440.63 & 28.38 & 8.80 & 5.55 \\
\hline $\mathrm{La}$ & 1810.50 & $\mathrm{La} 203$ & 1.17 & 2123.72 & 0.48 & 1.00 & 2123.72 & 0.54 & 0.17 & 1.00 & 2123.72 & 0.59 & 0.18 & 0.14 \\
\hline $\mathrm{Pb}$ & 1304.20 & Pbo & 1.08 & 1404.62 & 0.32 & 1.00 & 1404.62 & 0.35 & 0.11 & 1.00 & 1404.62 & 0.39 & 0.12 & 0.10 \\
\hline
\end{tabular}


Table 3-5. Nominal Blend Composition.

(0.8*AZ-101+0.8*AZ-102+0.37* C-106(Weiss) +0.15*AY-102)

\begin{tabular}{|c|c|c|c|c|c|c|c|c|c|c|c|c|c|c|}
\hline Element & $\begin{array}{c}\text { Element } \\
\text { wt kg }\end{array}$ & Oxide & $\begin{array}{l}\text { Oxide } \\
\text { factor }\end{array}$ & $\begin{array}{c}\text { Oxide wt } \\
\mathrm{kg}\end{array}$ & $\begin{array}{l}\text { Oxide } \\
\text { wt } x\end{array}$ & $\begin{array}{l}\text { Water } \\
\text { wash } \\
\text { factor }\end{array}$ & $\begin{array}{c}\text { Water } \\
\text { wash } \\
\text { solids, kg }\end{array}$ & $\begin{array}{l}\text { Water } \\
\text { wash } \\
\text { solid, } \\
\text { wt\% }\end{array}$ & $\begin{array}{c}\text { Water } \\
\text { wash } \\
\text { solids } \\
\text { concen- } \\
\text { tration, } \\
\mathrm{g} / \mathrm{L}\end{array}$ & $\begin{array}{c}\text { Caustic } \\
\text { wash } \\
\text { factor }\end{array}$ & $\begin{array}{c}\text { Caustic } \\
\text { wash } \\
\text { solids. kg }\end{array}$ & $\begin{array}{c}\text { Caustic } \\
\text { wash } \\
\text { solids, } \\
\text { wt } \%\end{array}$ & $\begin{array}{c}\text { Caustic } \\
\text { wash } \\
\text { solids } \\
\text { concen- } \\
\text { tration, } \\
\text { g/L }\end{array}$ & $\begin{array}{c}\text { Water } \\
\text { wash } \\
\text { conc., } \\
\mathbf{g} / \mathbf{L} \\
\text { (element } \\
\text { basis) }\end{array}$ \\
\hline Li & 20.80 & Li2O & 2.15 & 44.76 & 0.01 & 1.00 & 44.76 & 0.01 & 0.00 & 1.00 & 44.76 & 0.01 & 0.00 & 0.00 \\
\hline $\mathrm{Mg}_{\mathrm{g}}$ & 3003.20 & $\mathrm{MgO}$ & 1.66 & 4979.31 & 1.13 & 1.00 & 4979.31 & 1.26 & 0.39 & 1.00 & 4979.31 & 1.39 & 0.43 & 0.23 \\
\hline $\mathrm{Mn}$ & 2073.90 & $\mathrm{MnO} 2$ & 1.58 & 3280.91 & 0.74 & 1.00 & 3280.91 & 0.83 & 0.26 & 1.00 & 3280.91 & 0.92 & 0.28 & 0.16 \\
\hline Mo & 33.80 & $\mathrm{MoO} 3$ & 1.50 & 50.70 & 0.01 & 1.00 & 50.70 & 0.01 & 0.00 & 1.00 & 50.70 & 0.01 & 0.00 & 0.00 \\
\hline Nd & 1399.40 & $\mathrm{Nd} 2 \mathrm{O} 3$ & 1.17 & 1633.10 & 0.37 & 1.00 & 1633.10 & 0.41 & 0.13 & 1.00 & 1633.10 & 0.46 & 0.14 & 0.11 \\
\hline $\mathbf{N i}$ & 3317.70 & $\mathrm{NiO}$ & 1.27 & 4223.43 & 0.96 & 1.00 & 4223.43 & 1.07 & 0.33 & 1.00 & 4223.43 & 1.18 & 0.37 & 0.26 \\
\hline $\mathbf{P}$ & 1981.80 & P2O5 & 2.29 & 4540.30 & 1.03 & 0.92 & 4181.62 & 1.06 & 0.33 & 0.34 & 1421.75 & 0.40 & 0.12 & 0.14 \\
\hline $\mathrm{Pu}$ & 52.70 & $\mathrm{PuO2}$ & 1.13 & 59.60 & 0.01 & 1.00 & 59.60 & 0.02 & 0.00 & 1.00 & 59.60 & 0.02 & 0.01 & 0.00 \\
\hline $\mathrm{K}$ & 2217.40 & $\mathrm{~K} 2 \mathrm{O}$ & 1.21 & 2671.97 & 0.60 & 1.00 & 2671.97 & 0.67 & 0.21 & 1.00 & 2671.97 & 0.75 & 0.23 & 0.17 \\
\hline $\mathrm{Re}$ & 27.80 & $\mathrm{Re} 2 \mathrm{O3}$ & 1.13 & 31.39 & 0.01 & 1.00 & 31.39 & 0.01 & 0.00 & 1.00 & 31.39 & 0.01 & 0.00 & 0.00 \\
\hline Rh & 181.20 & Rh203 & 1.23 & 223.42 & 0.05 & 1.00 & 223.42 & 0.06 & 0.02 & 1.00 & 223.42 & 0.06 & 0.02 & 0.01 \\
\hline Ru & 568.10 & $\mathrm{Ru} 203$ & 1.23 & 698.76 & 0.16 & 1.00 & 698.76 & 0.18 & 0.05 & 1.00 & 698.76 & 0.20 & 0.06 & 0.04 \\
\hline Sb & 525.10 & $\mathrm{Sb}_{2} \mathrm{O}_{3}$ & 1.20 & 628.54 & 0.14 & 1.00 & 628.54 & 0.16 & 0.05 & 1.00 & 628.54 & 0.18 & 0.05 & 0.04 \\
\hline $\mathrm{Se}$ & 583.50 & $\mathrm{SeO} 2$ & 1.41 & 819.82 & 0.19 & 1.00 & 819.82 & 0.21 & 0.06 & 1.00 & 819.82 & 0.23 & 0.07 & 0.05 \\
\hline $\mathrm{Si}$ & 30315.0 & SiO2 & 2.14 & 64845.28 & 14.68 & 1.00 & 64845.28 & 16.36 & 5.07 & 1.00 & 64845.28 & 18.14 & 5.63 & 2.37 \\
\hline Ag & 526.0 & $\mathrm{Ag} 2 \mathrm{O}$ & 1.07 & 565.57 & 0.13 & 1.00 & 565.57 & 0.14 & 0.04 & 1.00 & 565.57 & 0.16 & 0.05 & 0.04 \\
\hline $\mathrm{Na}$ & 89457,30 & $\mathrm{Na} 2 \mathrm{O}$ & 1.35 & 120588.44 & 27.29 & 0.66 & 79347.19 & 20.02 & 6.21 & 1.00 & 79347.19 & 22.20 & 6.88 & 4.61 \\
\hline Sr & 213.60 & $\mathrm{SrO}$ & 1.18 & 252.69 & 0.06 & 1.00 & 252.69 & 0.06 & 0.02 & 1.00 & 252.69 & 0.07 & 0.02 & 0.02 \\
\hline $\mathrm{SO4}$ & 6213.90 & $\mathrm{SO} 4$ & 1.00 & 6213.90 & 1.41 & 0.47 & 2939.17 & 0.74 & 0.23 & 1.00 & 2939.17 & 0.82 & 0.25 & 0.23 \\
\hline $\mathrm{Te}$ & 457.00 & TeOs & 1.25 & 572.62 & 0.13 & 1.00 & 572.62 & 0.14 & 0.04 & 1.00 & 572.62 & 0.16 & 0.05 & 0.04 \\
\hline Th & 239.60 & $\mathrm{ThO}_{\mathrm{H}}$ & 1.14 & 272.66 & 0.06 & 1.00 & 272.66 & 0.07 & 0.02 & 1.00 & 272.66 & 0.08 & 0.02 & 0.02 \\
\hline $\mathrm{Ti}$ & 148.80 & $\mathrm{TiO} 2$ & 1.67 & 248.20 & 0.06 & 1.00 & 248.20 & 0.06 & 0.02 & 1.00 & 248.20 & 0.07 & 0.02 & 0.01 \\
\hline T1 & 1308.80 & $\mathrm{~T}_{2} \mathrm{O} 3$ & 1.12 & 1461.93 & 0.33 & 1.00 & 1461.93 & 0.37 & 0.11 & 1.00 & 1461.93 & 0.41 & 0.13 & 0.10 \\
\hline $\mathrm{U}$ & 4296.30 & U308 & 1.18 & 5065.34 & 1.15 & 1.00 & 5065.34 & 1.28 & 0.40 & 1.00 & 5065.34 & 1.42 & 0.44 & 0.34 \\
\hline V & 12.50 & V205 & 1.79 & 22.31 & 0.01 & 1.00 & 22.31 & 0.01 & 0.00 & 1.00 & 22.31 & 0.01 & 0.00 & 0.00 \\
\hline $\mathrm{Zn}$ & 134.00 & $\mathrm{ZnO}$ & 1.24 & 166.70 & 0.04 & 1.00 & 166.70 & 0.04 & 0.01 & 1.00 & 166.70 & 0.05 & 0.01 & 0.01 \\
\hline \multirow[t]{2}{*}{$\mathrm{Zr}$} & 11811.30 & $\mathrm{ZrO2}$ & 1.35 & 15945.26 & 3.61 & 1.00 & 15945.26 & 4.02 & 1.25 & 1.00 & 15945.26 & 4.46 & 1.38 & 0.92 \\
\hline & & Total & & 441866.10 & 100.00 & & 396347.84 & 100.00 & 31.01 & & 357469.15 & 100.00 & 31.01 & 31.01 \\
\hline
\end{tabular}


WHC-SD-WM-TI-768

Revision 0

This page intentionally left blank. 
WHC-SD-WM-TI-768

Revision 0

\subsection{VITRIFICATION}

Vitrification is a candidate process for converting the Hanford Site's HLW into a stable and durable (nonleachable) glass that is acceptable for disposal in a geological repository. The DOE has determined that the HLW disposal mission will be completed in two phases: (1) a Phase I demonstration where 3 to 6 percent of the HLW will be processed over a period of 5 to 9 years, and (2) a Phase II program where the remaining inventory of wastes will be treated in commercial scale facilities. The DOE has requested proposals for development of privately owned process facilities for Phase I HLW immobilization. The Phase I RFP provides for completion of design (December 31, 1999), starting hot operations of the HLW immobilization facility (June 1,2007 ), processing the minimum quantity of HLW (June 1, 2011), and decontamination and decommissioning and RCRA closure (June 1, 2013).

\subsection{IMPACT OF VITRIFICATION TECHNOLOGY ON FEED PROCESSABILITY}

The design and operating characteristics of the glass melter are expected to have a significant effect on processability of Hanford Site waste. Important design considerations include the normal operating temperature of the melter, materials of construction, energy source, use of mechanical or natural convection, mixing, cold cap coverage, potential volatility effects imparted to the melt, characteristics of the feed system, and type of glass pour system employed. These features will generally have a pronounced effect on the operating characteristics of the melter, properties of the glass, and glass-production rates obtained. Certain glass properties such as viscosity, electrical conductivity, and density are directly affected by composition and temperature of the molten glass. Other properties such as WOL and solubility of glass property-limiting components in the melt are also affected by temperature and composition of the glass. The volatility of ruthenium and cesium oxides, mercury, and sulfur and cadmium oxides are affected by temperature of the glass, cold cap coverage, REDOX control, and agitation. All of these aspects must be taken into consideration when formulating the optimum glass composition and assessing the processability of Hanford Site waste.

\subsection{STATUS OF VITRIFICATION TECHNOLOGY}

DOE has decided that the HLW immobilization at the Hanford Site will be performed in privately owned and operated facilities. The purpose of this study is to summarize and evaluate existing waste vitrification data and glass industry and DOE vitrification experience with similar wastes. The evaluation in this section focuses on melter feed processability, product/process control, state of technology development, facility/system integration, design life of the melter, melter system scaleup, product sampling and recycle, secondary waste streams, operability, factors affecting total cost, and features creating special or unusual safety or environmental problems. 


\subsection{HIGH-LEVEL WASTE MELTERS}

Several different melters have been extensively investigated for the Hanford Site HLW program. This includes both low-temperature $\left(1,150{ }^{\circ} \mathrm{C}\right)$ and high-temperature $\left(1,350{ }^{\circ} \mathrm{C}\right)$ joule-heated melters. A considerable number of melter tests have been performed with simulants and a few tests with samples of radioactive tank waste. Laboratory-scale tests with radioactive waste are needed to establish a link between simulant based studies and the behavior of actual tank waste sludges. Use of simulants needs to be verified by comparing the behavior of simulants to actual tank waste during feed preparation and vitrification of HLW. This comparison not only helps to validate testing results with simulants, but also provides a basis for validating glass property models used to formulate acceptable glass compositions. In the following section, the most important features and typical range of operating conditions will be described for each melter, together with a summary of results obtained from tests with radioactive wastes.

\subsubsection{Low-Temperature, Joule-Heated Melter (LTM)}

Joule-heated melters are typically heated by passing alternating electrical current through glass using submerged electrodes. The alternating current is conducted between two or more electrodes by mobile alkali metal ions (sodium or lithium) in the molten glass. Joule-heated melter designs vary with most employing a two-electrode arrangement. Others have a third electrode at the bottom to control the temperature of the bottom glass. The melter surface geometry is normally specified by the required surface area to meet production requirements and the depth required for adequate residence time. Glass residence times are typically determined by component volatility concerns (sodium metaborate volatility) and canister glass homogeneity considerations, that favor longer residence times for the HLW glass.

4.3.1.1 Melter Design. Joule-heated melters have certain advantages in comparison to other melters, especially the ability to suppress the volatilization of melt constituents and to melt opaque or "black" glasses where radiant heat transfer for indirect heating is limited. This melter is normally limited to a temperature range determined by the materials of construction for the refractories and electrodes. For the low-temperature melter, this temperature range is usually limited to about $1,150^{\circ} \mathrm{C}$ because of temperature limits imposed on the system by the submerged Inconel ${ }^{l} 690$ (high-chromium-nickel alloy) electrodes.

Most joule-heated melters are ceramic lined with Monofrax K-3 fused cast refractory or equivalent (chrome alumina-zirconia-silica), although a few designs are Inconel 600 or 690 metal lined. The metal melters either operate at a lower temperature $\left(<1,200^{\circ} \mathrm{C}\right)$ or are water cooled such that the metal liner is protected by a layer of frozen glass. Because glass is not electrically conductive at room temperature, joule-heated melters must have auxiliary

\footnotetext{
${ }^{1}$ Inconel is a trademark of Inco Alloys International, Incorporated.
} 


\section{Revision 0}

heating for initial startup. This is usually provided by electrical resistance heaters placed in the plenum space above the glass surface.

It is assumed that the HLW melters will most likely be slurry fed in a fashion similar to the Savannah River Defense Waste Processing Facility (DWPF) melter and designed HWVP melter. Low-temperature, joule-heated melters have been typically designed to accept a slurry feed (although calciner- and dry-fed melters have been evaluated as well). Depending on the size of melter, more than one slurry feed nozzle may be required to ensure adequate coverage of the melt surface. Significant work has been done to develop feed nozzles that will not clog. Current feed nozzles are water cooled to avoid plugging. The nozzles can be water flushed whenever the feed is shut off to ensure that the feed does not dry in the nozzle.

There are several variations of this melter design (sloped bottom, dry fed with an evaporator, agitated, etc). The flat-bottom melter is normally considered to be the reference case because most testing in this country has been conducted in flat-bottom melters. It is assumed that a low-temperature melter (LTM) will be equipped with a bottom drain and a differential pressure (vacuum) overflow system for discharging the glass. The side-entering overflow drain can be machined from a single block of Monofrax E or K-3 refractory and heated by passing an alternating current through the Monofrax E refractory or by using an array of silicon carbide heaters in the pour section of the overflow drain. The bottom drain consists of an inductively heated vertical pipe that is enclosed in a hollow copper-tube coil that serves as an induction heater and cooling coil. The drain operates as a freeze valve. When glass is to be poured, the drain pipe is inductively heated to melt the glass plug. The glass-pouring rate is essentially controlled by varying the induction power. When enough glass has been poured, the induction power is reduced until glass flow stops. The ability to adequately stop glass flow is determined by certain characteristics of the system, including the level of glass (or differential pressure at the bottom of the melter), the density and viscosity of the glass, and the diameter of the pour stream or throat diameter of the pour spout. These characteristics, in addition to the basic materials used, are important to the safe and reliable operation of an inductively heated bottom drain.

The ceramic-lined, joule-heated melter has been selected for HLW vitrification in the United States (DWPF, West Valley Demonstration Project [WVDP]), Belgium, Germany, Japan, and Russia. These melters have two or more layers of refractory inside a watercooled containment box. The glass-contacting refractory is usually high-chromia, fusion-cast refractory (K-3). The corrosion rate for K-3 is 10 to $20 \mu \mathrm{m} /$ day in the most aggressive areas at the melt line, but more typically 4 to $8 \mu \mathrm{m}$ /day as experienced by Pacific Northwest National Laboratory (PNNL) in the pilot-scale ceramic melter (PSCM). The fused-cast refractory in the HWVP melter design is $30-\mathrm{cm}$ thick. Assuming a maximum corrosion rate of $20 \mu \mathrm{m} /$ day, the expected refractory life would be 42 years. The electrical conductivity of glass-contacting refractory is important. If the refractory is too conductive (chromium content is too high), short circuits may develop between the electrodes via the refractory. This is only a concern with low-conductivity (low-alkali content) glasses. Because the 
fused-cast refractory is not very insulative, it is usually backed with layers of more insulative ceramics such as high-alumina-castable ceramics or ceramic board.

High-chromium alloys are typically used for bubblers and thermocouple wells to monitor density and temperature of the glass. These alloys are susceptible to chloride and sulfate molten salt attack, with chloride dissolving the protective oxide film and sulfate induced sulfidation of the base metal (Marra 1994). Inconel 690 catastrophically failed under these conditions in the PAMELA melter (Bickford 1986). Sulfidation of these alloys can only be prevented by avoiding the accumulation of molten salts in the glass and cooling these alloys below a critical temperature of $650^{\circ} \mathrm{C}$ for nickel based alloys.

A failure modes and effects analysis (FMEA) was conducted for the West Valley vitrification system in 1987. This analysis identified nineteen items that had a high or medium failure frequency with lengthy repair times. Most of the items identified were either external to the melter system (feed pump) or were melter components that are easily repaired or replaced (feed nozzle, thermowells). A few were identified whose failure could require replacement of the melter or significant repair periods. These include failure of the bottom electrode due to noble metals accumulation and glass discharge pluggage. The DWPF and HWVP designs are based on remote canyon facilities where access to equipment occurs from the top and all maintenance is accomplished with cranes and impact wrenches and not with manipulators. This leads to melter designs that have all access from the top because horizontal movement is difficult. The typical facility design calls for a valve corridor as a supplement to the canyon facility.

4.3.1.2 Glass Formulation. For LTMs, the waste form is assumed to be borosilicate glass. Borosilicate glass has been recommended based on its ability to immobilize a wide range of wastes, its insensitivity to radiation damage and general properties such as thermal stability, chemical durability, and processability. The acceptable range of glass composition is normally limited to the range of compositions previously evaluated for the HWVP Project (the composition variability study [CVS] range of compositions for which empirical glass property models are considered valid). However, some compositions in the CVS range may fail to meet all of the glass property constraints while others outside the CVS range could satisfy these requirements. Most CVS composition information was developed for NCAW, which is very similar in composition to the proposed Privatization Phase I demonstration feed.

Iron, chrome, and nickel spinels are usually the first crystals to form in the NCAW glass upon cooling. Sometimes, especially with high-zirconium feeds, zirconia-containing crystals also may form in the melt or in annealed samples of glass. The repository waste acceptance preliminary specifications (WAPS) do not limit the amount of crystalline material in the glass. However, spinel phases and other crystalline phases that may precipitate in the glass are of concern because they may reduce the durability of the glass or affect the operation of the melter by filling the melt cavity or pour spout with a crystalline phase sludge. Glass compositions for high-waste-oxide-loaded glasses typically are limited by the concentration of crystal-forming components in the glass. HLW glasses are typically tested 
by annealing the sample for 24 hours at $100{ }^{\circ} \mathrm{C}$ below the nominal operating temperature of the melter (viscosity of $4 \mathrm{~Pa}-\mathrm{s}$ ). Glasses are generally considered to be acceptable if they have less than 0.1 vol\% crystals after annealing.

In general, the following glass properties are also considered to be necessary for acceptable HLW glass:

- REDOX potential (determined by ferrous to ferric $\left[\mathrm{Fe}^{+2} / \mathrm{Fe}^{+3}\right]$ iron ratio) needed to control oxygen release and foaming tendency in the glass and for overly reduced glasses, precipitation of noble metals, spinel phases, and sulfide species. The $\mathrm{Fe}^{+2} / \mathrm{Fe}^{+3}$ ratio should range from 0.005 to 0.3 for acceptable REDOX control.

- Viscosity controlled in the range of 2 to $10 \mathrm{~Pa}$-s ( 20 to 100 poise) to limit refractory erosion-corrosion on the low side and to ensure adequate mixing and reasonable melt rates below the upper limit.

- Maximum liquidus temperature (temperature at which crystalline phases appear) set $100{ }^{\circ} \mathrm{C}$ below the nominal operating temperature of the melter so that crystals will not form in the melt.

- Electrical conductivity controlled to allow joule heating of the glass. This aspect depends on the distance between electrodes and acceptable current densities and localized corrosion rates of the electrodes. Electrical conductivity at $1,150{ }^{\circ} \mathrm{C}$ should be in the range of 0.18 to $0.5 \mathrm{~S} / \mathrm{cm}$, while the current density of the Inconel electrodes should be significantly below $1.6 \mathrm{~A} / \mathrm{cm}^{2}$ and more typically near $0.8 \mathrm{~A} / \mathrm{cm}^{2}$.

- Durability as determined by the acceptable leaching rate of the most soluble component in the glass (sodium and boron) compared to the EA glass, which is the reference durability standard for HLW glass (WAPS.DOE/EM-0093.Rev.1. May 1995).

Waste loading is defined as the weight percent of waste (oxides) in the HLW glass. This value is extremely important because it determines the required production rate of the melter and the total amount of glass produced from Hanford Site waste. Glass quantities are important for several reasons. First, the repository charges are likely to be in the range of $\$ 357,000$ for the standard $0.6-\mathrm{m}$ diameter by $3.05-\mathrm{m}$ tall canister, based on the present cost allocation between civilian and defense wastes (DOE 1995). This allocation assumes 9,860 canisters of HLW glass from the Hanford Site, although 13,800 standard canisters (at 51 percent WOL) could be produced and larger $0.6-\mathrm{m}$ diameter by $4.5-\mathrm{m}$ tall canisters may be used (Orme 1995). Overall, nearly $\$ 5$ billion in cost savings could be realized by increasing the WOL of Hanford Site waste from 25 to $51 \mathrm{wt} \%$ based on the standard size canister. Second, processing of each canister in the vitrification plant is very expensive. 


\section{WHC-SD-WM-TI-768}

Revision 0

Each canister must be cooled, welded close, decontaminated, and stored. This operation is likely to be one of the most costly operations in the plant.

4.3.1.3 Melter Performance Sensitivities. Compounds or elements that may require special treatment in the offgas include mercury, carbon-14 $\left({ }^{14} \mathrm{C}\right)$, and iodine-129 $\left({ }^{129} \mathrm{I}\right)$. These elements will not be incorporated into glass at $1,150{ }^{\circ} \mathrm{C}$, except for a minor amount of mercury, and must be captured in the offgas system and sent out as a secondary waste stream. Carbon-14 probably will be released to the atmosphere as long as Clean Air Act Amendments of 1990 standards are met. Chloride, fluoride, technetium, cesium, cadmium, and ruthenium oxide are partially soluble in glass but require special consideration in the offgas treatment system for recycle. These components are routinely scrubbed out of the melter offgas and may be recycled to the melter feed.

Noble metal oxides and alloys of rhodium, palladium, silver, and ruthenium are virtually insoluble in borosilicate glass. Previous tests and studies have indicated that accumulation of these metal oxides can cause premature failure of the melter due to electrical short circuiting even at concentrations as low as $0.1 \mathrm{wt} \%$ in glass. Designs developed by the Germans (Kernforschungszentrum Karlsruhe $\mathrm{GmbH}[\mathrm{KfK}]$ ) have proven that accumulation of noble metals in the bottom of the melter can be avoided by having a steeply sloped (75 degrees) bottom that allows the precipitated noble metal particles to be drained out of a bottom drain.

The Japanese have developed a method that limits the deposition of noble metals by cooling the glass near the melter floor (Elliott 1994). The cold, viscous glass near the bottom acts as a barrier and significantly slows the settling rate of noble metal particles. Therefore, noble metals remain in the molten glass above the layer of cold glass that is maintained at a temperature of 850 to $950{ }^{\circ} \mathrm{C}$. Such glasses can be poured through the bottom drain of the melter when the bottom temperature is raised from 900 to $1,050{ }^{\circ} \mathrm{C}$ to reduce the viscosity of the glass. With this method, the Japanese have demonstrated that ruthenium oxide accumulation rates could be reduced from 43 to 17 percent and PdO from 39 to 3 percent, with some tests indicating less than 1 percent of the noble metals having accumulated in the melter.

The Phase I water washed nominal blend contains $0.38 \mathrm{wt} \%$ noble metals $\left(\mathrm{Ag}_{2} \mathrm{O}\right.$, $\left.\mathrm{Ru}_{2} \mathrm{O}_{3}, \mathrm{Rh}_{2} \mathrm{O}_{3}, \mathrm{TeO}_{2}, \mathrm{PdO}\right)$. At 48 percent WOL in the glass, the noble metals concentration should be $0.182 \mathrm{wt} \%$. If the Phase I feeds are processed separately, Tank 241-AZ-101, 241-AZ-102, and 241-C-106 glasses should nominally contain $0.17,0.11$, and 0.24 wt \% noble metal oxides, respectively. Recent grab samples from Tank 241-C-106 indicate the bounding noble metal oxide concentration could be as high as $0.52 \mathrm{wt} \%$ in glass because of the amount of silver and ruthenium in this waste. This noble metals concentration is likely to cause premature failure of the melter electrodes and bottom refractory (based on the agglomeration and alloying characteristics of low melting temperature of silver $\left(960{ }^{\circ} \mathrm{C}\right)$ and laboratory-scale tests performed with feeds containing from 0.33 to $0.46 \mathrm{wt} \%$ noble metals). An added concern is the high silver inventory in Tank $241-\mathrm{AY}-102$, with $1.85 \mathrm{wt} \%$ silver oxide $\left(\mathrm{Ag}_{2} \mathrm{O}\right)$. Glass samples from the research scale melter (RSM) test performed in 1991 
by PNNL contained from 0.332 to $0.465 \mathrm{wt} \%$ noble metal oxides, with accumulation rates of 5 to 46 percent of the incoming feed, depending on the concentration of noble metals. The electrodes and bottom refractory of the RSM were badly damaged, in all likelihood by accumulation of noble metals from the $0.465 \mathrm{wt} \%$ noble metals feed. RSM glass samples taken from the bottom of RSM contained clusters of $\mathrm{RuO}_{2}$ needles and metallic particles of $\mathrm{Ru} / \mathrm{Rh}$ surrounded by layers of $\mathrm{Pd} / \mathrm{Ag} / \mathrm{Te}$ alloy and $\mathrm{RuO}_{2}$ (Cooper et al. 1994).

Semi-volatile elements are only partially soluble in glass. Table 4-1 shows typical melter decontamination factor (DF) for elements with DFs below 300, except $\mathrm{HgO}$. Two different values are shown for $\mathrm{HgO}$ to illustrate the effect of glass composition.on melter DFs for highly volatile components.

The DF is defined as the ratio of the mass flow of an element into the melter divided by the mass flow in the offgas. The DFs shown in Table 4-1 were determined for liquid-fed melters operating at $1,150^{\circ} \mathrm{C}$. Volatility losses from liquid-fed melters are affected by certain operating parameters (e.g., cold cap coverage, plenum temperature, and feed/glass composition). Because of its high-specific activity, cesium volatility is of particular interest. Cesium is believed to volatilize as cesium oxide, cesium hydroxide, or other compounds (Erlebach 1960, IAEA 1982). If chloride is present, cesium chloride is assumed to be the primary volatile species (Burkholder and Allen 1987). The presence of technetium has been shown to increase cesium volatility, as well, due to formation of cesium technetium oxide. Upon addition of technetium to a feed, cesium losses increased from 2-5 to 18 percent (Baumgartner 1984).

Radioactive materials are confined to the melter and offgas system because the melter plenum and overflow are kept under slight vacuum to prevent the airborne release of such materials to the melter cell. However, deposits can still accumulate in the offgas line. This can be controlled by using a film cooler to quench and dilute the hot particulate material from the melter or by designing the offgas line so that deposits can be physically removed with a reamer, as was done for the PAMELA melter.

Joule-heated melters typically have side- or bottom-entering electrodes constructed of Inconel 690. Submerged Inconel-690 electrodes corroded at an average rate of $3 \mu$ /day in the PSCM after 3 years of operation (Barnes and Larson 1981). Inconel materials in the plenum space have been severely attacked due to halides and sulfates in the feed stream (Dierks 1980). Corrosion attack by sulfur and its compounds has been found to be a potentially severe problem. In the PAMELA plant, the baffle plate and the wall opposite the offgas inlet corroded through in less than 150 hours (Chapman 1983). The material used in this area of the PAMELA was the European equivalent of 304 stainless steel (SS). Inconel 690 does provide some improvement in time to failure, but the performance characteristics of this alloy have not been determined over the projected life of the plant. Most Inconel materials exposed to offgas (thermowells and bubblers) can be replaced remotely. 
Table 4-1. Liquid-Fed Ceramic Melter Decontamination Factors.

\begin{tabular}{|l|c|c|c|}
\hline \multicolumn{1}{|c|}{ Oxide } & Wt\% oxide in waste & Melter DF & Reference $^{\mathrm{a}}$ \\
\hline $\mathrm{CdO}$ & 1.03 & 250 & Perez 1994 \\
\hline $\mathrm{Cl}$ & 0.16 & 4 & Perez 1994 \\
\hline $\mathrm{Cs}_{2} \mathrm{O}$ & 0.15 & $100-200$ & Perez 1994 \\
\hline $\mathrm{F}$ & 0.03 & 4 & Perez 1994 \\
\hline $\mathrm{HgO}$ & 0.0005 & 2833.3 & Pegg et al. 1994 \\
\hline $\mathrm{HgO}$ & 0.008 & 1.3 & Chapman 1987 \\
\hline $\mathrm{Rb}_{2} \mathrm{O}_{3}$ & 0.007 & 290.0 & Perez 1994 \\
\hline $\mathrm{Rh}_{2} \mathrm{O}_{3}$ & 0.013 & 29.0 & Whittington 1993 \\
\hline $\mathrm{Ru}_{2} \mathrm{O}_{3}$ & 0.047 & 10.0 & Scott 1985 \\
\hline $\mathrm{SO}_{3}$ & 0.341 & 6.4 & Goles and Nakaoka 1990 \\
\hline $\mathrm{SeO}_{2}$ & 0.01 & 4 & Perez 1994 \\
\hline $\mathrm{TC}_{2} \mathrm{O}_{7}$ & 0.021 & 2.5 & Chapman 1987 \\
\hline $\mathrm{TeO}_{2}$ & 0.003 & 11.0 & Scott 1985 \\
\hline
\end{tabular}

$\mathrm{DF}=$ Decontamination factor

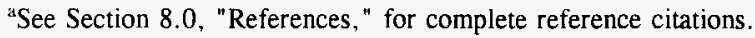

If the melter plenum is maintained at high temperature, it may be assumed that organics are mostly destroyed in the plenum space of the melter. The plenum temperature is normally about $650^{\circ} \mathrm{C}$ when supplemental plenum heaters are used. The destruction and removal efficiency (DRE) for formic acid was recently determined for liquid-fed ceramic melters. The destruction of formate was at least 99.8 percent for feeds containing 37 to $46 \mathrm{~g} / \mathrm{L}$ formate (Perez 1994). Similar tests have been performed at SRS to assess destruction of organics in the DWPF melter (Crow 1984, 1987).

Joule-heated melters have been demonstrated with nonradioactive simulants at SRS (scale-glass melter with $1.2-\mathrm{m}^{2}$ surface area and melt rates of $45 \mathrm{~kg} / \mathrm{h}$ ), at West Valley Nuclear Services (melter of $2.15 \mathrm{~m}^{2}$ area and melt rates of $45 \mathrm{~kg} / \mathrm{h}$ ), and at PNNL (LFCM of $1.05-\mathrm{m}^{2}$ surface area and melt rates of 25 to $30 \mathrm{~kg} / \mathrm{h}$, and the PSCM of $0.76-\mathrm{m}^{2}$ surface and melt rates of $22 \mathrm{~kg} / \mathrm{h}$ ).

Existing test facilities, in addition to those previously mentioned, are the K-6 melter in Germany $\left(0.88 \mathrm{~m}^{2}\right)$, the advanced B melter in Japan $\left(0.88 \mathrm{~m}^{2}\right)$, the Integrated DWPF Melter System (IDMS) melter at SRS $\left(0.29 \mathrm{~m}^{2}\right)$, the $1 / 10$ th-scale $\left(0.25 \mathrm{~m}^{2}\right)$ and PSHTM $\left(2 \mathrm{~m}^{2}\right)$ 
melters at PNNL, and finally the two Duramelters $\left(0.13\right.$ and $\left.0.33 \mathrm{~m}^{2}\right)$ at GTS Duratek. Remote operation of LTMs in radioactive environments have been demonstrated in Russia (Mayak plant), Belgium (PAMELA plant), and the United States (radioactive liquid-fed ceramic melters at PNNL, SRS, and WVDP). Similar systems have been designed but not operated in Japan (Tokai) and the United States (HWVP). The SRS and WVDP production melters $\left(2.5 \mathrm{~m}^{2}\right)$ are currently being used to process radioactive wastes at their respective sites.

The reliability of a joule-heated melter can be expressed as the total online efficiency (TOE). This is defined as the total hours that a melter operates divided by the total hours that a melter is in place, including the time for melter changeout. A TOE of 60 percent was assumed for the HWVP design. This was arrived at by assuming the melter was online 70 percent of the time with a 6-month total shutdown every 3 years. This was considered to be a conservative design basis because efficiencies of greater than 85 percent have been regularly attained with test melters.

The average online efficiency of the PAMELA melter was 85 percent, while the efficiency was greater than 98 percent during the recent LFCM tests conducted by PNNL (Perez 1994). In practice, melter efficiencies of less than 70 percent should be expected during the first year of operation for a production plant with some increase in online efficiency as problems are worked out of the process. Because the waste compositions are likely to vary, some uncertainty needs to be assumed in the analysis and control of waste composition through the process and in the control of glass composition. Based on the experience at SRS, it is reasonable to assume that the HLW vitrification process will produce glasses of about 85 to 90 percent of the theoretical WOL. This offset is generally caused by the statistical uncertainties that must be taken into account in liquidus temperature predictions (both model and process uncertainties) (DWPF manual B-DD-S-00001).

4.3.1.4 Estimated Melter Design Life. The minimum melter lifetime of the HWVP melter was estimated to be 2 years and the expected lifetime 3 to 5 years. The IDMS melter at SRS has experienced very little refractory wear after 5 years of continuous idling (at $900{ }^{\circ} \mathrm{C}$ ) and operation (at $1,150^{\circ} \mathrm{C}$ ). Monofrax E and K-3 refractories have shown little or no corrosion after 5 years of operation at WVDP. If refractory wear is the only consideration, ceramic-lined melters should last for 10 years or more under continuous service conditions (at $1,150^{\circ} \mathrm{C}$ ).

The most likely scenario for early melter failure is believed to be the accumulation of noble metals on the melter floor causing short circuiting of the lower set of electrodes. The potential accumulation of noble metals could be mitigated by one of several control strategies. One strategy is to blend the Phase I feeds to reduce the likely concentration of noble metals. Another approach developed at SRS involves adding water to the glass surface during idling periods to increase convective flow in the melter, thus limiting the settling of noble metals. A recent analysis of IDMS data from SRS suggests that 70 to 80 percent of the noble metals may have settled from the melt due to the absence of sufficient convection when the melter was idled (Hutson 1994). 


\section{Revision 0}

Another important aspect relates to the composition and electrical characteristics of the glass found in the bottom of the IDMS melter. This glass apparently contained enough precipitated spinel that the glass was relatively insulating compared to other melter bottom glasses with similar concentrations of noble metals (PAMELA). In this case, the electrical characteristics of the bottom glass appear to be controlled by the composition of the melt. Still another strategy is to design a sloped-bottom melter and bottom-drain system for sludgeforming noble metal wastes or to devise a control scheme, such as the one developed by the Japanese, that allows for the efficient purging of noble metals. Agitation of the glass with mechanical mixers or air spraying may also reduce accumulation of sludge. These are important strategies to consider for noble metal wastes such as those in the Phase.I tanks.

4.3.1.5 Product/Process Control. The product quality, as such, will be determined by glass formulation. Glass development is done to ensure that the final product will be at least as durable as the reference EA glass when tested with the product consistency test (PCT) and Materials Characterization Center (MCC)-1 leach test. Waste product homogenization is ensured by maintaining a sufficient residence time in the melter. For the DWPF melter, the residence time averages 2 days. This long residence time may be necessary to ensure proper dissolution and mixing of the waste in the glass product (although adequate results could be obtained in a much shorter period of time for some wastes). Tracer tests have indicated the melter acts as a continuous stirred tank reactor so the waste should be well mixed with the glass-forming components in the melt. With a longer residence time, insoluble particles or crystals will have more opportunity to settle to the melter floor.

Certain measurements are required to ensure safe process control in a remote operating environment. This includes temperature measurements in the glass, plenum space, glass discharge areas, refractories, and cooling water circuits. The most difficult parameter to control remotely is the amount of cold cap coverage (i.e., fraction of melt surface covered with solid unmelted feed material). The feed must be controlled such that the melt pool is not completely flooded with feed causing potential bridging of the cold cap (i.e., adherence of the cold cap to the walls of the melter). Insufficient cold cap coverage will lead to increased volatilization and gas release, and excessive heat loss. The cold cap coverage is usually controlled based on past experience and plenum temperature (which increases as the cold cap is melted by hot glass) and visual inspection with a remove TV. Remote infrared cameras have been investigated by PNNL as a control option but have not been implemented to date. The melter plenum must be maintained at a slight vacuum to avoid contamination of the process cells. This control is dynamic because of the variable nature of the melter cold cap.

Joule-heated melters operate continuously under very steady conditions such that process upsets are rare. Glass production rates, however, can be adversely affected if foam develops in the glass melt. Gas bubbles are commonly formed when the REDOX state of the melt is abruptly changed with a rapid increase in electrode power and glass temperatures in the vicinity of the electrodes. This effect can be suppressed by adding chemical reductants such as formic and glycolic acid to the melter feed. During idle periods, water can be fed to the melter to cool the upper glass surface to minimize volatilization and to increase 
convective mixing so noble metals will not settle in the melter. Ceramic-lined, joule-heated melters are based on a mature technology that has been tested since the early 1970's for the vitrification of HLW.

4.3.1.6 Data Needs. Most HLW glass formulations are being developed for high-wasteoxide-loaded glasses. For high-nickel, -chromium, or -iron feeds, spinel precipitation and sludge accumulation problems are likely to occur. Precipitation and settling characteristics of a spinel type phase need to be assessed under different operating conditions. Viscosity and electrical conductivity measurements are needed to determine whether spinel phase enriched sludge deposits are primarily a mechanical or electrical problem in the melter. Glass melts containing from 2 to $10 \mathrm{vol} \%$ crystals are known to have approximately Newtonian viscoelastic behavior (Plodinec 1986).

NCAW waste by definition is comprised of wastes from Tanks 241-AZ-101 and 241-AZ-102. Based on crucible tests to date, glasses with 33 wt\% NCAW do not form spinel phase, while glasses with 40 to $50 \mathrm{wt} \%$ NCAW typically precipitate from 0.5 to $1.0 \mathrm{vol} \%$ spinel at $1,050{ }^{\circ} \mathrm{C}\left(100{ }^{\circ} \mathrm{C}\right.$ below the operating temperature of the melter) (Fini and Hrma 1994, Hrma and Bailey 1994). At $50 \mathrm{wt} \% \mathrm{NCAW}$, baddeleyite $\left(\mathrm{ZrO}_{2}\right)$ appears in the glass and its concentration increases sharply with waste loading (Hrma and Bailey 1995). The WOL for NCAW glass could be increased by 30 to 40 percent if a practical sludge removal system is developed for the low temperature melter. Several different approaches may be potentially promising, including: (1) a cone-shaped melter bottom, bottom electrode and drain system, (2) a detachable side entering drain with features to induce flow, (3) a ceramic stir or bubbler system to mobilize the solids and the injection of low viscosity glass to purge the sludge, or (4) a top entering vacuum removal system, such as the one developed by PNNL for West Valley (evacuated canister design) (Barnes 1989). If sludge removal capabilities could be developed for the LTM, LTM glasses could be formulated to match, or possibly exceed the waste oxide loading capabilities of the HTM, significantly reducing the predicted life-cycle costs for the LTM.

\subsubsection{High-Temperature, Joule-heated Melter (HTM)}

The HTM operates on the same principal as other electric melters by passing an alternating electrical current through the glass to induce self heating into the molten glass. The HTM, as embodied in the most recent PNNL design, has two electrode systems, a pair of shielded and water-cooled Inconel/molybdenum electrodes inserted from the top, and a second set of Monofrax ${ }^{2} \mathrm{E}$ (high-chromium oxide) refractory electrodes incorporated into the melter's refractory envelope. Because these electrodes are capable of higher temperature performance, this melter can be typically operated at temperatures of 1,350 to $1,550{ }^{\circ} \mathrm{C}$. It is anticipated that higher operating temperatures will lead to a corresponding increase in the melt rate and waste oxide loading potential for HLW glasses. The melt surface geometry and melter configuration are dictated by electrode spacing and surface area requirements, and by the glass residence time and production requirements of the melter (melt rate capacity). 
4.3.2.1 Melter Design. The HTM refractory envelope designed by PNNL consists of Monofrax E and Monofrax K-3 fused cast refractory for the glass-contact zone in the melt cavity, surrounded by more insulative layers of high-alumina Alfrax-66 refractory and ceramic board (Duraboard-LD), and a water-cooled Inconel shell. The small-scale high temperature melter (SSHTM) test melter developed by PNNL uses a pair of Monofrax E electrodes spaced $38 \mathrm{~cm}$ apart. This melter is equipped with a differential pressure overflow system and an inductively heated bottom drain for glass pouring. The SSHTM overflow discharge uses electrical resistance heaters to maintain a molten pour stream. The bottom drain consists of an inductively heated, vertical pipe or udder inserted into a hole in the melter floor. This pipe is surrounded by a copper coil that serves as an induction heater and cooling coil. The drain valve assembly is typically sealed and connected to the glass canister with a metal bellows that can be filled with nitrogen to protect the drain valve materials.

The LTM and HTM designs are generally similar except for the electrodes. Candidate electrode materials are currently being evaluated for the HTM, including molybdenum, chromium, chromium-alumina, chromia, Monofrax E, platinum-10 percent rhodium, tantalum, tin oxide, tungsten, and graphite.

Molybdenum electrodes are typically used in most commercial electric melters except for those making glasses that contain species such as lead and arsenic that require more oxidizing conditions (Calmus 1995). Hanford Site HLW sludges contain lead and arsenic, as well as metals of lower oxidation potential, or ones that may form low-temperature melting alloys with molybdenum. Molybdenum electrode stems must be cooled or maintained in an inert atmosphere because molybdenum rapidly oxides in air above $600^{\circ} \mathrm{C}$. Several electrode holders have been designed to protect top entering molybdenum electrodes from oxidation in air. Tin oxide electrodes could be used in a oxidizing environment, but are limited to a maximum operating temperature of about 1,300 to $1,350{ }^{\circ} \mathrm{C}$. These electrodes also have a lower maximum current density $\left(0.5 \mathrm{~A} / \mathrm{cm}^{2}\right.$ compared to $2 \mathrm{~A} / \mathrm{cm}^{2}$ for molybdenum), and typically require more elaborate bus bar connections because tin oxide is electrically insulating below $900{ }^{\circ} \mathrm{C}$ (Calmus 1995).

For oxides such as tin oxide, chromia and the chromia-alumina refractories (Monofrax E and K-3), simple dissolution (interdiffusion of components of the electrode and melt) is usually the dominate corrosion mechanism (Woolley 1995). Monofrax E electrodes are also susceptible to "rat-holing," where corrosion channels preferentially develop because of the large grain size and the nonuniform distribution of grain size and possible voids in the material. Recent PNNL tests have indicated that rat-holing is a severe problem with Monofrax E electrodes. Three of four electrodes apparently failed due to rat-holing in the SSHTM. Graphite is limited by its low allowable current density $\left(0.2 \mathrm{~A} / \mathrm{cm}^{2}\right)$ and its incompatibility with oxidizing glasses. Platinum electrodes commonly degrade in a reducing environment or by forming low melting temperature alloys with impurities in the melt.

Refractory corrosion rates typically double with an increase of 50 to $100{ }^{\circ} \mathrm{C}$ in glass temperature (Woolley 1991). This general correlation only applies to glasses of similar composition and cannot be used to predict the corrosion behavior of higher viscosity glasses. 


\section{Revision 0}

Corrosion rates are typically influenced by the temperature and viscosity of the glass (with lower viscosity glasses producing higher corrosion rates), current density of the electrodes, and the presence of reducible ions and molten salts in the melt. Corrosion results for candidate electrode materials are summarized in Table 4-2 (Freeman 1995). These results show that platinum-rhodium and Monofrax $\mathrm{E}$ are the preferred electrode materials for the HTM based on static corrosion tests.

Table 4-2. Corrosion Rates for Candidate Electrode Materials in HTB-650 Glass at $1,400{ }^{\circ} \mathrm{C}$.

\begin{tabular}{|l|c|c|c|c|}
\hline \multicolumn{1}{|c|}{ Material } & $\begin{array}{c}\text { Applied } \\
\text { current, A/cm } 2\end{array}$ & $\begin{array}{c}\text { Electrochem. } \\
\text { corrosion, } \\
\text { mm/year }\end{array}$ & $\begin{array}{c}\text { Corrosion (7 } \\
\text { day static), } \\
\text { mm/year }\end{array}$ & $\begin{array}{c}\text { Corrosion (24 h } \\
\text { static) mm/year }\end{array}$ \\
\hline $\begin{array}{l}\text { Platinum-10\% } \\
\text { Rhodium }\end{array}$ & 1.0 & 2.9 & & \\
\hline $\begin{array}{l}\text { Platinum-10\% } \\
\text { Rhodium }\end{array}$ & 1.6 & & -0.5 & \\
\hline Monofrax E & 0.2 & 5.0 & 0.1 & \\
\hline Chromia & 0.2 & 36.6 & 2.0 & 114.4 \\
\hline Molybdenum & 1.0 & 77.6 & 14.0 & 85.8 \\
\hline Tungsten & 1.0 & 87.9 & 42.8 & 332.8 \\
\hline Tin Oxide & 0.2 & 192.3 & 86.7 & 244.1 \\
\hline Tantalum & 1.0 & & $>133.0$ & $>1068$ \\
\hline Chromium & 1.0 & & $>163.6$ & \\
\hline $\begin{array}{l}\text { Chromium- } \\
\text { alumina }\end{array}$ & 1.0 & & $>151.7$ & \\
\hline
\end{tabular}

For the SSHTM melter, Monofrax E electrodes corroded at a rate of about $50 \mathrm{~mm} /$ year at the melt line and $25 \mathrm{~mm} /$ year below the melt line (general corrosion rate, exclusive of ratholing effects, over an 8 month period at $1,350^{\circ} \mathrm{C}$ ). This rate was found to be much higher than the previous estimates from electrochemical and static tests because the electrodes were exposed to melter feed materials as they were being processed into glass. Monofrax K-3, however, corroded at a rate of about $9 \mathrm{~mm} / \mathrm{year}$ in the SSHTM, or slightly less than the rate of $13.5 \mathrm{~mm} /$ year from static tests (Freeman 1995). Based on these rates, the useable lifetime for $30 \mathrm{~cm}$ of K-3 refractory should be about 20 to 25 years, but only several years for $30 \mathrm{~cm}$ of Monofrax E refractory in the HTM. 
4.3.2.2 Glass Formulation. For the HTM, the waste form is assumed to be sodiumalumina-silicate high-temperature glass, where silica is the only glass former added, or borosilicate glass because of its acceptability as a recommended waste form. These glasses can be readily processed at $1,350{ }^{\circ} \mathrm{C}$ with acceptable viscosity, durability, and crystallinity (or liquidus temperature) properties in the melter. It is anticipated that HTM waste acceptance and glass property limits will be identical to the established limits for LTM glasses. HTM glass formulations should be based on identical constraints for REDOX, viscosity, electrical conductivity, liquidus temperature and durability.

Several glass formulations have already been developed for the HTM, including glasses based on NCAW and DST/SST blend, using CVS property and composition models (Kirn 1994). These glasses were formulated to find the optimum frit composition $\left(\mathrm{Na}_{2} \mathrm{O}\right.$, $\mathrm{Li}_{2} \mathrm{O}, \mathrm{B}_{2} \mathrm{O}_{3}$, and $\mathrm{SiO}_{2}$ ) for glasses with $50 \mathrm{wt} \% \mathrm{NCAW}$ waste, and to find the maximum waste loading of DST/SST glass, in the range of 57 to $71 \mathrm{wt} \%$, using $\mathrm{SiO}_{2}$ as the only glass former.

For NCAW glass, it was determined that sodium and lithium oxides should be added in lieu of boric oxide to suppress the precipitation of spinel type phases and to increase the waste oxide loading of NCAW waste. The optimum glass contained $50 \mathrm{wt} \% \mathrm{NCAW}$, $44 \mathrm{wt} \% \mathrm{SiO}_{2}$, and $6 \mathrm{wt} \% \mathrm{Na}_{2} \mathrm{O}$, with a melting temperature of $1,350{ }^{\circ} \mathrm{C}$ and negligible crystallinity. DST/SST glasses were formulated to minimize precipitation of spinel phases and $\mathrm{ZrO}_{2}$. The optimum glass contained $62 \mathrm{wt} \% \mathrm{DST} / \mathrm{SST}$ blend waste and $38 \mathrm{wt} \% \mathrm{SiO}_{2}$, with a melting temperature of $1,350^{\circ} \mathrm{C}$ (at $4 \mathrm{~Pa}$-s) and less than $0.5 \mathrm{vol} \%$ crystallinity (with 90 percent of the crystals being less than 1 micron in diameter). These glasses are of interest because they were used to formulate feeds for the SSHTM melter.

During FY 1994, two melter tests, SSHTM-1 and SSHTM-2, were completed using a simulated NCAW waste and blended DST/SST waste (Abrigo 1995b, Smith 1995). The SSHTM-1 test was divided into two segments with two separate feeds: (1) a 50 wt\% NCAW feed using glycolic acid in lieu of formic acid as the chemical reductant and (2) a $50 \mathrm{wt} \%$ NCAW feed using only nitric acid (and no organic acid) to adjust the rheology of the feed. This test was performed to evaluate the use of glycolic acid as an alternate reductant (to suppress hydrogen production in the melter feed preparation process) and to assess the need for chemical reductants in the melter. The SSHTM-2 test consisted of four additional segments with two feeds: (1) a $47 \mathrm{wt} \%$ NCAW feed modified with boric and nitric acid and (2) a $65 \mathrm{wt} \%$ DST/SST feed simulant. This test sequence was performed to evaluate the performance of the HTM with a high-waste loaded glass. Additional tests, SSHTM-4 and SSHTM-5, were performed during FY 1995 to evaluate feed additives (boric acid), feed oxide loading, temperature effects and pouring characteristics of the new bottom drain (using a $1.9 \mathrm{~cm}$ instead of $1.27 \mathrm{~cm}$ orifice) (Lamar 1995). 
4.3.2.3 Melter Performance Sensitivities. Certain elements and compounds cannot be incorporated into high-temperature glass. Such materials include ${ }^{14} \mathrm{C}$, and ${ }^{129} \mathrm{I}$. These must be captured in the offgas system and sent out as secondary waste. The exception is ${ }^{14} \mathrm{C}$, that will probably be released to the atmosphere as long as Clean Air Act Amendments of 1990 standards are met.

Noble metal oxides and alloys (rhodium, palladium, $\mathrm{RuO}_{2}$, and silver) are virtually insoluble in borosilicate glass. Previous studies have indicated that accumulation of these metals can cause premature failure of the low-temperature, ceramic-lined melter due to electrical short circuiting at concentrations as low as $0.1 \mathrm{wt} \%$ in glass (see-Section 5.7.6).

During segment 1 of SSHTM-1, $1200 \mathrm{~L}$ of NCAW feed (with glycolic acid) were processed at temperatures of 1,350 to $1,400{ }^{\circ} \mathrm{C}$, producing $520 \mathrm{kgs}$ of glass (Abrigo 1995b, Smith 1995). Glass processing rates varied from 16 to about $26 \mathrm{~kg} / \mathrm{h}-\mathrm{m}^{2}$. An insulating layer of scum formed on the surface of the glass toward the end of this test segment, but this layer was finally removed after plenum heaters were used to increase the surface temperature of the melt. Approximately $150 \mathrm{kgs}$ of glass were produced during segment 2 of SSHTM-1, using nitric acid adjusted NCAW feed. The glass production rate averaged about $10 \mathrm{~kg} / \mathrm{h}-\mathrm{m}^{2}$ at $1,350{ }^{\circ} \mathrm{C}$. As indicated by the low production rate, nitric acid laden feed did not process well in the SSHTM. The feed formed a mound under the feed nozzle and did not spread out over the cold cap surface. Boric acid was added to the feed and within a few hours the feed was spreading over the cold cap and forming a flexible and highly desirable cold cap with active venting.

Boric acid modified NCAW feed (with about $3 \mathrm{wt} \% \mathrm{~B}_{2} \mathrm{O}_{3}$ ) was also used during the first segment of SSHTM-2, where the glass production rates increased to about $22 \mathrm{~kg} / \mathrm{h}-\mathrm{m}^{2}$ because of enhanced fluidity of the cold cap. When the temperature was raised from 1,375 to $1,425{ }^{\circ} \mathrm{C}$, the glass rate increased to about $30 \mathrm{~kg} / \mathrm{h}-\mathrm{m}^{2}$. During segment 2 of SSHTM-2, approximately $1,700 \mathrm{~L}$ of blended DST/SST feed (HTB650) were introduced to the SSHTM and processed at 1,350 and $1,400{ }^{\circ} \mathrm{C}$ to assess the impact of temperature on processing rate and offgas composition. The DST/SST feed (with $0.3 \mathrm{wt} \% \mathrm{~B}_{2} \mathrm{O}_{3}$ ) tended to mound beneath the feed nozzle and formed a rigid cold cap at $1,350{ }^{\circ} \mathrm{C}$, with an average glass production rate of about $22 \mathrm{~kg} / \mathrm{h}-\mathrm{m}^{2}$. The glass production rate increased to about $28 \mathrm{~kg} / \mathrm{h}-\mathrm{m}^{2}$ after the temperature was raised to $1,400{ }^{\circ} \mathrm{C}$. During segment 3 of SSHTM-2, a ceramic agitator (resembling an Archimedes screw) was lowered into the melt and rotated at 40 to $60 \mathrm{rpm}$ to enhance the processing rate of the SSHTM. It was determined that the glass production rate averaged about $20 \mathrm{~kg} / \mathrm{h}-\mathrm{m}^{2}$ with agitation at $1,350{ }^{\circ} \mathrm{C}$, or about the same rate as one might achieve without agitation. Melter performance results have not been fully analyzed and reported for test segments SSHTM-4 and SSHTM-5. Table 4-3 summarizes the glass production data currently available from the SSHTM. 
WHC-SD-WM-TI-768

\section{Revision 0}

Table 4-3. Glass Production Rates for the Small-Scale High-Temperature Melter.

\begin{tabular}{|c|c|c|c|c|c|}
\hline Melter test & Feed type & $\begin{array}{l}\text { Plenum } \\
\text { heating }\end{array}$ & $\begin{array}{l}\text { Melter surface } \\
\text { area, } \mathrm{m}^{2}\end{array}$ & $\begin{array}{c}\text { Glass } \\
\text { temp., }{ }^{\circ} \mathrm{C}\end{array}$ & $\begin{array}{c}\text { Glass } \\
\text { production rate, } \\
\mathrm{kg} / \mathrm{h}-\mathrm{m}^{2}\end{array}$ \\
\hline SSHTM-1,1 & $\begin{array}{c}50 \% \text { NCAW } \\
\text { (gly.acid) } 390 \text { g-TO/L }\end{array}$ & $\mathrm{N}$ & 0.21 & 1,350 & 16 \\
\hline SSHTM-1,1 & $\begin{array}{l}50 \% \text { NCAW (gly.acid) } \\
390 \text { g-TO/L }\end{array}$ & $\mathbf{N}$ & 0.21 & 1,400 & 26 \\
\hline SSHTM-1,2 & $\begin{array}{c}50 \% \text { NCAW (nit.acid) } \\
380 \mathrm{~g}-\mathrm{TO} / \mathrm{L}\end{array}$ & $\mathrm{N} / \mathrm{Y}$ & 0.21 & 1,350 & 10 \\
\hline $\begin{array}{l}\text { SSHTM-1,2 } \\
\text { SSHTM-2,1 }\end{array}$ & $\begin{array}{c}50 \% \text { NCAW } \\
\text { (bor.acid) } 341 \mathrm{~g}-\mathrm{TO} / \mathrm{L}\end{array}$ & $\mathrm{N}$ & 0.21 & 1,350 & 22 \\
\hline SSHTM-2,1 & $\begin{array}{c}50 \% \text { NCAW } \\
\text { (bor.acid) } 341 \mathrm{~g}-\mathrm{TO} / \mathrm{L}\end{array}$ & $\mathbf{N}$ & 0.21 & 1,375 & 21 \\
\hline SSHTM-2,1 & $\begin{array}{c}50 \% \text { NCAW } \\
\text { (bor.acid) } 431 \text { g-TO/L }\end{array}$ & $\mathbf{N}$ & 0.21 & 1,425 & 30 \\
\hline SSHTM-2,2 & $\begin{array}{c}65 \% \text { DST/SST } \\
\text { (nit.acid) } 535 \mathrm{~g}-\mathrm{TO} / \mathrm{L}\end{array}$ & $\mathrm{N}$ & 0.21 & 1,350 & 22 \\
\hline SSHTM-2,2 & $\begin{array}{c}\text { 65\% DST/SST } \\
\text { (nit.acid) } 535 \mathrm{~g}-\mathrm{TO} / \mathrm{L}\end{array}$ & $\mathrm{N}$ & 0.21 & 1,400 & 28 \\
\hline SSHTM-2,3 & $\begin{array}{c}65 \% \text { DST/SST } \\
\text { (nit.acid) w agitat. } 535 \\
\text { g-TO/L }\end{array}$ & $N$ & 0.21 & 1,350 & 20 \\
\hline SSHTM-4 & $\begin{array}{c}\text { Shim. NCAW All } \\
\text { Blend (nit.acid)avg. } \\
4 a \& 4 b\end{array}$ & $\mathbf{N}$ & 0.26 & 1,400 & 17.7 \\
\hline SSHTM-4a & $\begin{array}{l}\text { Shim. NCAW All } \\
\text { Blend }^{3} 409 \mathrm{~g}-\mathrm{TO} / \mathrm{L}\end{array}$ & $\mathrm{N}$ & 0.26 & 1,400 & 21.9 \\
\hline SSHTM-4b & $\begin{array}{l}\text { Shim. NCAW All } \\
\text { Blend }^{2} 272 \mathrm{~g}-\mathrm{TO} / \mathrm{L}\end{array}$ & $\mathrm{N}$ & 0.26 & 1,400 & 17.7 \\
\hline SSHTM-5 & $\begin{array}{l}\text { All Blend (Optima) } \\
376 \mathrm{~g}-\mathrm{TO} / \mathrm{L}\end{array}$ & $N$ & 0.26 & 1.425 & 14.6 \\
\hline
\end{tabular}

$\mathrm{g}-\mathrm{TO} / \mathrm{L}=$ grams of total oxide per liter.

aShimmed NCAW: $9.3 \mathrm{~g} / \mathrm{l} \mathrm{Al}_{2} \mathrm{O}_{3}, 8.21 \mathrm{~g} / \mathrm{l} \mathrm{Fe} \mathrm{O}_{3}, 16.12 \mathrm{~g} / 1 \mathrm{Na}_{2} \mathrm{O}$ and $52 \mathrm{~g} / 1 \mathrm{SiO}_{2}$.

${ }^{\mathrm{b}}$ All blend prepared by Optima Chemical: $31.8 \mathrm{~g} / \mathrm{l} \mathrm{Al} \mathrm{O}_{3}, 26.4 \mathrm{~g} / \mathrm{l} \mathrm{Fe} \mathrm{O}_{3} \mathrm{O}_{3}$,

$84.2 \mathrm{~g} / \mathrm{l} \mathrm{Na} \mathrm{N}_{2} \mathrm{O}$ and $144.1 \mathrm{~g} / \mathrm{l} \mathrm{SiO}_{2}$. 


\section{WHC-SD-WM-TI-768}

\section{Revision 0}

Table 4-4 provides comparable results for the LTM based on various PNNL melter campaigns (Abrigo 1995b).

Table 4-4. Glass Production Rates for Low Temperature Melters.

\begin{tabular}{|c|c|c|c|c|c|}
\hline Melter test & Feed type & $\begin{array}{l}\text { Plenum } \\
\text { heating }\end{array}$ & $\begin{array}{c}\text { Melter surface } \\
\text { area, } \mathrm{m}_{2}\end{array}$ & $\begin{array}{c}\text { Glass temp. } \\
{ }^{\circ} \mathrm{C} \\
\end{array}$ & $\begin{array}{c}\text { Glass production } \\
\text { rate, } \mathrm{kg} / \mathrm{h}-\mathrm{m}^{2}\end{array}$ \\
\hline HBCM-86-2A & HWVP & $\mathrm{N}$ & 0.25 & 1,150 & 29 \\
\hline HBCM-86-2B & HWVP & $\mathbf{N}$ & 0.25 & 1,150 & 35 \\
\hline HBCM-86-2C & HWVP & $\mathrm{N}$ & 0.25 & 1,150 & 29 \\
\hline LFCM-5 & SRP & $Y$ & 1.05 & 1,150 & 18 \\
\hline LFCM-6 & SRP & $\bar{Y}$ & 1.05 & 1,150 & 14 \\
\hline LFCM-7B & SRP & $\mathrm{Y}$ & 1.05 & 1,150 & 23 \\
\hline PSCM-3 & SRP & $\mathrm{N}$ & 0.73 & 1,150 & 22 \\
\hline PSCM-4 & SRP & $\mathrm{N}$ & 0.73 & 1,150 & 38 \\
\hline PSCM-15B & WV & $\mathrm{N}$ & 0.73 & 1,135 & 27 \\
\hline PSCM-16 & WV & $\mathrm{N}$ & 0.73 & 1,160 & 19 \\
\hline PSCM-20 & WV & $\mathrm{N}$ & 0.73 & 1,175 & 18 \\
\hline PSCM-20 & WV & $\mathrm{N}$ & 0.73 & 1,175 & 14 \\
\hline PSCM-17 & HWVP & $\mathrm{N}$ & 0.73 & 1,150 & 9 \\
\hline PSCM-22A & HWVP & $\mathrm{N}$ & 0.73 & 1,180 & 17 \\
\hline PCSM-22B & HWVP & $\mathrm{N}$ & 0.73 & 1,180 & 19 \\
\hline PSCM-23 & HWVP & $\mathrm{N}$ & 0.76 & 1,150 & 28 \\
\hline LFCM-8A & HWVP & $\mathrm{Y}$ & 1.05 & 1,170 & 28 \\
\hline LFCM-8B & HWVP & $\mathrm{Y}$ & 1.05 & 1,160 & 26 \\
\hline
\end{tabular}

HBCM = High-Bay Ceramic Melter

LFCM = Liquid-Fed Ceramic Melter

PSCM = Pilot-Scale Ceramic Melter

HWVP = Hanford Waste Vitrification Project (similar to Phase I feed)

SRP = Savannah River Plant (PUREX simulant similar to Phase I feed)

WV = West Valley Demonstration Project (commercial HLW feed simulant). 
On average, the SSHTM produced about $22.9 \mathrm{~kg} / \mathrm{h}-\mathrm{m}^{2}$ of glass during these trials (at $1,350{ }^{\circ} \mathrm{C}$ ), while the LTM has typically produced about $20.8 \mathrm{~kg} / \mathrm{h}-\mathrm{m}^{2}$ of glass at $1,150{ }^{\circ} \mathrm{C}$. Based on these results, the melt rate enhancement features of the SSHTM (higher operating temperatures, more flexible glass formulations) did not produce the expected increase in glass throughput capacity anticipated for the HTM.

High waste oxide loaded glasses can also be formulated for the LTM by formulating glasses beyond the normal liquidus temperature limit for the LTM. For example, optimum formulations for the HTM might contain as much as $50 \mathrm{wt} \%$ NCAW waste (with 1.5 to $4.6 \mathrm{vol} \%$ crystals because of refractory corrosion, Table 4-7). Similar glasses can be formulated for the LTM that contain $33 \mathrm{wt} \%$ NCAW (with no evidence of crystallinity after 24 hours at $1,050{ }^{\circ} \mathrm{C}$ ), and 40 to $45 \mathrm{wt} \%$ NCAW (with 0.4 to 0.9 vol\% crystals after 24 hours at $1,050^{\circ} \mathrm{C}$ ) (Vienna et al. 1996, Fini and Hrma 1994). Dissolution of refractory components into glass increases aluminum and chrome levels and thus reduces the previously expected waste oxide loading advantage of the HTM (if corrosion source term components are included in calculating liquidus temperature limits for glass formulation). Refractory corrosion increased the predicted liquidus temperature of N508 glass from 1,162 to $1,346{ }^{\circ} \mathrm{C}$ during the SSHTM tests. This change was found to be consistent with the increase in crystallinity of the glass (from $<0.1$ vol\% crystallinity based on crucible tests to $4.59 \mathrm{vol} \%$ crystallinity in the melter product glass). For other wastes such as the all tank blend, the HTM appears to offer a 5 to $10 \mathrm{wt} \%$ oxide loading advantage over the LTM based on liquidus temperature properties of rare earth (cerium-neodymium) zirconates (Vienna and Hrma 1995).

During several of the recent SSHTM tests, glass production rates increased 30 to 35 percent when the temperature was raised from $1,350^{\circ} \mathrm{C}$ to about $1,425^{\circ} \mathrm{C}$. The viscosity of the glass was also reduced from $7 \mathrm{~Pa}$-s to about $3.7 \mathrm{~Pa}$-s over this temperature range. This noticeable increase in the production capacity could be due to viscosity effects and the increase of convection in the melter, rather than to thermal effects in the cold-cap region. Similar affects were also observed during the RSM test where the melt rate increased (by a factor of 2.3) after the temperature was raised from 1,050 to $1,200{ }^{\circ} \mathrm{C}$ (and glass viscosity consequently reduced from $18 \mathrm{~Pa}$-s to $4 \mathrm{~Pa}$-s) (Research Scale Melter Test Report, comparing segments 4 and 7, [Cooper et al. 1994]). While viscosity manipulation techniques may be useful for enhancing the melt rate, these conditions could also lead to some acceleration of refractory corrosion in the melter. If the viscosity limits are eventually reduced, glass production rates could be increased in the LTM by reformulating the glasses for lower viscosity or by using electrodes capable of higher temperature performance in the LTM. The SSHTM tests also show that HTM feeds should had improved fluidity in the cold cap region with the addition of 3 to $5 \mathrm{wt} \% \mathrm{~B}_{2} \mathrm{O}_{3}$. 


\section{Revision 0}

Semivolatile elements have a limited solubility in glass. Aerosol samples were taken during SSHTM-1 and SSHTM-2 to assess the impact of elevated temperature on the distribution of volatile and semivolatile components in the waste. Table 4-5 shows the melter decontamination factor (DF) for elements with DFs below 300 . Volatility losses from liquid-fed melters are believed to be affected by cold cap coverage, plenum temperature, and the temperature and composition of the glass (presence of chlorides and other volatile species). From this data, it appears that volatility losses did not increase significantly when the temperature was raised from 1,150 to $1,400{ }^{\circ} \mathrm{C}$.

Table 4-5. Melter Decontamination Factors for High-Temperature and Low-Temperature Melter (Abrigo 1995b).

\begin{tabular}{|l|c|c|c|c|c|}
\hline Waste oxide & $\begin{array}{c}\text { SSHTM-1,1 } \\
(\mathrm{HTM})\end{array}$ & $\begin{array}{c}\text { SSHTM-2,1/ } \\
\text { SSHTM-2,2 } \\
(\mathrm{HTM})\end{array}$ & $\begin{array}{c}\text { LFCM-1 } \\
\text { (LTM) }\end{array}$ & $\begin{array}{c}\text { PSCM-23 } \\
(\text { LTM) }\end{array}$ & $\begin{array}{c}\text { LFCM-8 } \\
\text { (LTM) }\end{array}$ \\
\hline $\mathrm{Ag}_{2} \mathrm{O}$ & 80 & $28 / 365$ & & & 60 \\
\hline $\mathrm{CdO}$ & 195 & $52 / 2,029$ & & & 250 \\
\hline $\mathrm{Cr}_{2} \mathrm{O}_{3}$ & 200 & $21 / 491$ & & 440 & 317 \\
\hline $\mathrm{Cs}_{2} \mathrm{O}$ & & $35 / 38$ & 44 & 77 & \\
\hline $\mathrm{K}_{2} \mathrm{O}$ & 174 & $134 / 9,794$ & & & \\
\hline $\mathrm{Li}_{2} \mathrm{O}$ & 120 & $11 / 599$ & & 110 & 196 \\
\hline $\mathrm{MoO}_{3}$ & 156 & $415 / 2,487$ & & 2,600 & 54 \\
\hline $\mathrm{P} 2 \mathrm{O}^{2}$ & 43 & $6 / 334$ & & 6 & 10 \\
\hline $\mathrm{SO}_{3}$ & 620 & $68 / 616$ & & 960 & 390 \\
\hline ZnO & $90 \%$ & $85 \% / 95 \%$ & & & \\
\hline $\begin{array}{l}\text { Cold Cap } \\
\text { Coverage }\end{array}$ & 1,400 & $1,390 / 1,350$ & & 1,150 & 1,160 \\
\hline Glass Temp. ${ }^{\circ} \mathrm{C}$ & & $53 / 136$ & 940 & 1,500 & \\
\hline
\end{tabular}

HTM $=$ High-temperature melter LTM $=$ Low-temperature melter. 
Table 4-6 provides component volatility data from the low-level waste (LLW) melter tests conducted with Hanford Site's double-shell slurry feed (DSSF simulant) (Wilson 1996, Whyatt, Shade, and Stegen 1996). This information is of interest because it shows how volatility losses can vary with the design and operating characteristics of the melter. Babcock \& Wilcox (B\&W) used a slurry-fed cyclone combustion melter. The feed was atomized and sprayed into a cyclone combustion flame, with volatilization and high entrainment losses. Combustion furnaces of this type typically operate with an exit gas temperature of 1,800 to $3,000{ }^{\circ} \mathrm{C}$. Westinghouse Science and Technology Center (WTSC) used a plasma torch-fired cupola furnace and atomized slurry feed, with significant volatility losses as expected due to high temperatures in the plasma jet...The U.S. Bureau of. Mines (USBM) employed a carbon electrode melter using prereacted, dried, and pelletized feed as a batch blanket. Due to the high temperatures involved, volatility losses were high until steps were taken to increase the diameter of the electrodes and reduce the voltage to control volatility losses from the glass (by changing from arc furnace to joule-heating, thus reducing glass temperatures near the electrodes). Vectra demonstrated a high temperature $\left(1,500{ }^{\circ} \mathrm{C}\right)$ joule-heated skull melter with fully calcined, dried and slurry feeds. Because of the angular placement of the electrodes, the central part of the melt pool was rarely covered with the cold cap, explaining the high volatility losses in Table 4-6. The glass melt rates with slurry feed were greater than rates with calcined or simulated calcine dry feeds. Duratek employed a low temperature $\left(1,150^{\circ} \mathrm{C}\right)$ joule-heated melter with Inconel electrodes, an air-lift overflow drain system and air bubblers to enhance convection and mixing in the melter. Average processing rates with slurry feed varied from 61 to $66 \mathrm{~kg} / \mathrm{h}-\mathrm{m}^{2}$. (about three times the rate of the SSHTM with HLW feed). Volatility losses were moderately high because of the air bubblers and associated disruption of the cold cap. Envitco demonstrated a high temperature $\left(1,450\right.$ to $\left.1,500^{\circ} \mathrm{C}\right)$ joule-heated melter with spray-dried and slurry feeds. Volatility losses were exceptionally low because of full cold-top batch coverage and the use of submerged, side-entering molybdenum electrodes that did not interfere with the cold cap.

Glasses produced during the SSHTM- 1 and SSHTM- 2 melter tests also contained much more crystalline material than anticipated from laboratory studies. The main species appear to be $\mathrm{Fe}, \mathrm{Ni}, \mathrm{Cr}$ spinel $\left(\mathrm{NiFe}_{2} \mathrm{O}_{4}\right.$ or trevorite), caused by the dissolution of Monofrax $\mathrm{E}$ and K-3 refractory and the related increase of chromium in the glass. Laboratory glasses are typically formulated from dry chemical oxides and carbonates, and unless adjustments are made, would not reflect the changes in composition that might arise from corrosion processes in the melter. In the laboratory, SSHTM-1 and SSHTM-2 samples contained less than 0.1 vol\% crystals, while production samples from the SSHTM contained from 1.48 to $4.61 \mathrm{vol} \%$ crystals, Table $4-7$. While most of the spinel particles were small, these crystals could easily accumulate as a sludge forming layer in the melter, especially if the glass temperature is reduced or crystals are allowed to grow and settle during idling of the HTM. A spinel phase sludge layer could easily plug the bottom drain and eventually affect the electrical characteristics of the glass and electrodes. 


\section{Revision 0}

Table 4-6. Percent of Feed Components Volatilized During Low-Level Waste Melter Tests.

\begin{tabular}{|l|c|c|c|c|c|c|c|}
\hline Comp. & Target Glass, wt\% & B\&W & WSTC & USBM & Vectra & Duratek & Envitco \\
\hline $\mathrm{B}_{2} \mathrm{O}_{3}$ & $5-9$ & 70 & 24 & 19 & 15 & 0.6 & 0.2 \\
\hline $\mathrm{Cl}$ & 0.37 & 88 & 88 & 97 & 64 & 48 & 1 to 13 \\
\hline $\mathrm{Cs}{ }_{2} \mathrm{O}$ & 0.15 & 85 & 84 & 40 & 41 & 14 & 0.6 \\
\hline $\mathrm{F}$ & 0.31 & 93 & 91 & 99.7 & 16 & 53 & 0.9 \\
\hline $\mathrm{I}$ & 0.14 & 95 & 98 & N/A & -83 & 82 & 10 \\
\hline $\mathrm{K}_{2} \mathrm{O}$ & $1.5-3.7$ & 55 & 49 & 26 & 16 & 0.6 & 0.05 \\
\hline $\mathrm{Na}_{2} \mathrm{O}$ & $18.8-20$ & 41 & 17 & 7.6 & 13.5 & 0.6 & 0.05 \\
\hline $\mathrm{P}_{2} \mathrm{O}_{5}$ & 0.2 & 46 & 45 & 55 & 1.7 & N/A & 0.05 \\
\hline $\mathrm{SO}_{4}$ & 0.22 & 55 & 36 & 94 & 85 & N/A & 53 \\
\hline
\end{tabular}

B\&W $=$ Babcock \& Wilcox

Duratek $=$ Duratek, Inc.

Envitco = Envitco, Inc.

USBM = U.S. Bureau of Mines

Vectra $=$ Vectra Technologies, Inc.

WSTC $=$ Westinghouse Science and Technology Center.

Table 4-7. Composition and Volume Percent Crystals in Small-Scale High Temperature Melter Tests 1 and 2.

\begin{tabular}{|c|c|c|c|c|}
\hline Melter test & Glass & Glass comp. & Vol\% crystals & Comment \\
\hline Laboratory & N508 Glass & $\begin{array}{l}14.0 \% \mathrm{Fe}_{2} \mathrm{O}_{3} \\
0.24 \% \mathrm{Cr}_{2} \mathrm{O}_{3}\end{array}$ & $\begin{array}{l}<0.1 \%(24 \mathrm{~h} \\
\left.\text { @ } 1,350^{\circ} \mathrm{C}\right)\end{array}$ & $\begin{array}{c}<0.5 \text { micron } \\
1-4 \text { micron } \\
\text { spinel }\end{array}$ \\
\hline SSHTM-1 & Glycolic N508 & $\begin{array}{c}12.7 \% \mathrm{Fe}_{2} \mathrm{O}_{3} \\
0.93 \% \mathrm{Cr}_{2} \mathrm{O}_{3} \\
\end{array}$ & $1.48 \%$ & $\begin{array}{c}\text { spinel and } \\
\text { second phase }\end{array}$ \\
\hline SSHTM-1 & Nitric N508 & $\begin{array}{c}10.6 \% \mathrm{Fe}_{2} \mathrm{O}_{3} \\
0.78 \% \mathrm{Cr}_{2} \mathrm{O}_{3}\end{array}$ & $4.59 \%$ & $\begin{array}{c}\text { very small } \\
\text { crystals }\end{array}$ \\
\hline $\begin{array}{l}\text { SSHTM-1 } \\
\text { SSHTM-2 }\end{array}$ & $\mathrm{Nit}+\mathrm{Bor} \mathrm{N} 508$ & $\begin{array}{c}12.11 \% \mathrm{Fe}_{2} \mathrm{O}_{3} \\
0.5 \% \mathrm{Cr}_{2} \mathrm{O}_{3}\end{array}$ & $2.98 \%$ & $\begin{array}{c}\text { spinel, not } \\
\text { evenly } \\
\text { distributed }\end{array}$ \\
\hline Laboratory & HTB65 Glass & $\begin{array}{l}8.6 \% \mathrm{Fe}_{2} \mathrm{O}_{3} \\
0.8 \% \mathrm{Cr}_{2} \mathrm{O}_{3}\end{array}$ & $<0.01 \%$ & $\begin{array}{c}<0.5 \text { micron } \\
0.5-5 \text { micron } \\
\text { spinel }\end{array}$ \\
\hline SSHTM-2 & $\begin{array}{c}\text { DST/SST Blend } \\
\text { (HTB65) }\end{array}$ & $\begin{array}{l}9.0 \% \mathrm{Fe}_{2} \mathrm{O}_{3} \\
0.7 \% \mathrm{Cr}_{2} \mathrm{O}_{3}\end{array}$ & $4.61 \%$ & $\begin{array}{l}\text { spinel, varying } \\
\text { in size }\end{array}$ \\
\hline
\end{tabular}




\subsubsection{Radioactive Melter Tests}

During Phase I of the alternate acquisition strategy (privatization) at the Hanford Site tests will be needed to evaluate the composition and properties of radioactive wastes and HLW glasses produced from these wastes. Small-scale feed preparation and crucible-level vitrification tests are necessary, and mostly sufficient, to evaluate feed rheology, offgas, feed preparation chemistry and glass properties such as viscosity, electrical conductivity, liquidus temperature and durability, and the optimum waste oxide loading of HLW glass. These tests also can be used to derive volatility data for certain radionuclides. Larger-scale tests are generally needed to assess the melt rate, foaming potential, cold cap.spreading characteristics, phase separation of molten salts and refractory layers in the cold cap and volatile components in the waste. Cold simulants can be used to duplicate many of these conditions, but certain tests, especially those involving waste form qualification, must be performed with representative samples of radioactive waste. In this section, a brief summary will be provided describing radioactive melter tests at Savannah River (DWPF mini-melter), Pacific Northwest National Laboratory (radioactive liquid-fed ceramic melter), British Nuclear Fuels, Ltd (BNFL) and COGEMA (experience with radioactive wastes and simulants), and Hanford Site facilities that might be available for radioactive tests.

4.3.3.1 Savannah River Site (DWPF Mini-Melter). Small-scale tests are being conducted at Savannah River to evaluate each batch of radioactive waste before processing in the DWPF. Laboratory and bench-scale tests are currentiy being performed in the Shielded Cells Facility (SCF) to: (1) demonstrate compliance with the Waste Acceptance Product Specifications (WAPS), (2) verify the composition and disposition of minor and major radionuclides, and (3) demonstrate the process control model and composition control strategy for each batch of radioactive waste. The SCF includes all of the equipment needed for feed preparation and vitrification of the waste in a slurry-fed $1 / 100$ th DWPF scale jouleheated melter (DWPF mini-melter, $20 \mathrm{~cm}$ diameter, $15 \mathrm{~cm}$ deep with a $10 \mathrm{~kg}$ of glass inventory).

Savannah River has developed a set of algorithms or glass composition control models that can be used to assess the processability of the feed and durability of the HLW glass (feed-forward control system). These algorithms are included in the Product Composition Control System (PCCS) being used to formulate and optimize the composition of the feed to the DWPF melter.

The DWPF mini-melter was first used in 1991 to demonstrate the capabilities of the PCCS model, and later to process as much as $10 \mathrm{kgs}$ of radioactive waste from tank 51 into HLW glass. Smaller batches of radioactive giass have also been made from crucible melts of pretreated tank 51 waste. These tests have generally demonstrated that HLW glasses of acceptable durability can be produced with a composition profile very similar the one predicted with the PCCS model (Andrews 1991, 1992, Ferrara 1995). 


\section{Revision 0}

The total inventory of long-lived radionuclides must also be determined for the Savannah River glass (radionuclides with half-lives longer than 10 years and concentrations greater than $0.05 \mathrm{Ci}$ up to 1,100 years after production, WAPS specification 1.2). There are twenty-four radionuclides of regulatory significance in Savannah River's waste, but only four of these will be routinely measured in the HLW glass $\left({ }^{137} \mathrm{Cs}\right.$, ${ }^{90} \mathrm{Sr},{ }^{238} \mathrm{Pu}$, and $\left.{ }^{238} \mathrm{U}\right)$. Table 4-8 provides a list of the most important radionuclides in Savannah River's waste. The minor radionuclides can be estimated from the waste dilution factors measured in the DWPF mini-melter (by comparing to concentration of minor radionuclides in waste and glass) (Bibler 1994). If this method is acceptable to the regulators, the DWPF mini-melter will be used to satisfy WAPS 1.2 reporting requirements for minor radionuclides in the waste.

Table 4-8. Principal Radionuclides in Savannah River's Waste.

\begin{tabular}{|c|c|c|c|}
\hline Radionuclide & Half-Life & Source & Analytical Method \\
\hline Ni-59 & $7.5 E 04$ & Neutron Act. & Sepn. \& ICP-MS \\
\hline Ni-63 & $1.0 \mathrm{E} 02$ & Neutron Act. & Beta Count \\
\hline Se-79 & $3.3 \mathrm{E} 04$ & Fission Prod. & Fission Yield \\
\hline Sr-90 & 28 & Fission Prod. & Beta Count \\
\hline Zr-93 & $1.5 \mathrm{E} 06$ & Fission Prod. & ICP-MS \\
\hline Nb-93m & 16 & Decay Prod. & Half-Life Calc. \\
\hline Tc-99 & 2.1 E05 & Fission Prod. & ICP-MS \\
\hline Pd-107 & $6.5 E 06$ & Fission Prod. & ICP-MS \\
\hline Sn-126 & $1.0 E 05$ & Fission Prod. & Fission Yield \\
\hline Cs-135 & $2.3 E 06$ & Fission Prod. & ICP-MS \\
\hline Cs-137 & 30 & Fission Prod. & Gamma Count \\
\hline Sm-151 & 90 & Fission Prod. & ICP-MS \\
\hline Th-230 & $7.5 E 04$ & Decay Prod. & Half-Life Calc. \\
\hline U-234 & $2.5 E 05$ & Waste Prod. & ICP-MS \\
\hline U-238 & $4.5 E 09$ & Waste Prod. & ICP-MS \\
\hline Np-237 & $2.1 E 06$ & Neutron Act. & ICP-MS \\
\hline Pu-238 & 88 & Neutron Act. & Alpha Count \\
\hline Pu-239 & $2.4 E 04$ & Neutron Act. & ICP-MS \\
\hline Pu-240 & $6.6 E 03$ & Neutron Act. & ICP-MS \\
\hline Pu-241 & 14 & Neutron Act. & ICP-MS/Gamma \\
\hline Pu-242 & $3.8 E 05$ & Neutron Act. & ICP-MS \\
\hline Am-241 & $4.3 E 02$ & Decay Prod. & Gamma Count \\
\hline Am-243 & $7.4 E 03$ & Neutron Act. & ICP-MS \\
\hline Cm-244 & 18 & Neutron Act. & ICP-MS \\
\hline
\end{tabular}




\subsubsection{Pacific Northwest National Laboratory (Radioactive, Liquid-Fed Ceramic} Melter (RLFCM). A pilot-scale RLFCM was installed in B-cell of the 324 Building in 1984 (Dierks 1987). This system was utilized to test radioactive feed simulants for the West Valley Demonstration Project and to produce a limited number of canisters of cesium and strontium enrich glass for the Federal Republic of Germany. The pilot-scale RLFCM consisted of a joule-heated melter, canister-handling turntable, glass-level detection system, waste feed preparation equipment, and offgas and condensate treatment racks. The melter was sized to produce about $11 \mathrm{kgs}$ of glass per hour, with a melt pool area of $0.53 \mathrm{~m}^{2}$, glass depth of $36 \mathrm{~cm}$ and nominal inventory of $475 \mathrm{~kg}$ of glass. Certain components in the system were designed for remote replacement, including the thermal wells, thermocouples, bubblers, the feed nozzle, air-lift lance and viewing camera (Burkholder 1985).

During the initial campaign, $300 \mathrm{kgs}$ of radioactive West Valley simulant glass were produced containing $75,000 \mathrm{Ci}$ of activity. Certain problems occurred, including the accumulation of cesium and sodium metaborate deposits in the melter offgas line and problems with the melter feed pump, feed nozzle, discharge heaters and tank agitator system. A new reaming device was installed to prevent future pluggage problems in the melter offgas line. Corrosion problems were also noted in the feed nozzle due to halides in the feed. Three different electrical power control schemes were evaluated for the melter, each having a different affect on the melter during glass pouring or other periods of thermal instability. These schemes included resistance feedback control (based on the electrical resistance of the glass), resistance plus glass weight factor control (to mitigate power transients following a batch pour), and glass temperature control (based on an average of three temperatures with alarms and limits). Foaming was usually observed after an upset in the process such as a glass pour or an abrupt increase in power to the electrodes. Other studies were performed to characterize melter effluents and the performance of the offgas cleaning system.

Melter feed entrainment losses were much higher than might have been anticipated from previous tests with cold simulants (volatile condensable components and particulates from the melter). The decontamination factors (DFs) for strontium and cesium were an order of magnitude lower than from cold simulant tests with comparable feeds (consistent with a large increase in particulate carryover and pluggage of the melter offgas line with cesium and sodium metaborate deposits) (Burkholder 1987). Melter operations were terminated in February, 1986 because the discharge-section heaters failed. The heaters were evidently damaged by the condensation of an electrically conductive (cesium chloride) salt layer, that caused an electrical short. This problem also seems to have been associated with uncontrolled discharges of low viscosity glass, due to foaming and pressure fluctuations in the melter. Pressure fluctuations are thought to have been caused by bridging of the cold cap and/or pluggage of the offgas line. Glass level control was also effected by continuing corrosion of the bubbler tubes (that generally lasted for only six months), and deterioration of the vacuum control system in the melter. Discharge heater failure problems were eventually solved by increasing the spacing between heater elements and filling the void with fibrous insulating material (Burkholder 1986, 1987). 
4.3.3.3 British Nuclear Fuels, Ltd and COGEMA. BNFL is currently operating production-scale vitrification facilities in Sellafield, based on the COGEMA AVH and AVM designs. The main operations involve preparation of the acidic HLW feed, transfer of the HLW feed to the calciner, calcination and associated offgas treatment, melting and pouring HLW glass from the induction-heated, inconel shell melter, welding of the container lid, decontamination and monitoring of the product container, and transfer of the container to storage.

BNFL and COGEMA also have pilot-scale and full-scale non-radioactive prototype facilities in Sellafield and Marcoule. The BNFL development program is divided into four main areas: (1) engineering, including demonstration of full-scale equipment components and processes, (2) process development, comprising analytical development, simulant production and optimization of the calcination and melting processes, (3) process control, covering techniques used for product quality control, and (4) glass technology, including development of optimum glass formulations and measurement of key properties such as glass composition and durability.

Glass formulation and development is an evolutionary process. Laboratory studies are typically conducted with simulants and radioactive samples at crucible level in a glove box. Once the candidate glasses have been identified, these compositions as cold simulants are usually tested in a pilot-scale calciner and melter to optimize the process and concentration of additives used in the calciner. Pilot-scale results are then used to define the flowsheet and processes for full-scale demonstration in prototype production facilities.

With this approach, about 90 to 95 percent of the required tests can be conducted with cold simulants. Radioactive wastes as such only need to be evaluated at crucible level in the laboratory. By performing comparative tests with simulants and radioactive waste, BNFL has found that simulant results almost always match the results obtained with radioactive waste. The most surprising difference is the high volatility of certain radionuclides when radioactive wastes are used. Cesium and technetium frequently volatilize from such wastes as cesium pertechnate $\left(\mathrm{CsTcO}_{4}\right)$. Tellurium in this waste also may alloy with Inconel, reducing the life of the induction-heated melters used by BNFL and COGEMA.

Process related measurements, such as melt rate, are determined from pilot or full-scale tests with cold simulants. Even with this level of support, it took nearly three years of effort to qualify the BNFL vitrification process, with feed-forward (glass composition) control, for the two radioactive wastes from Magnox and Thorp. These wastes are similar to the acidic, high-level PUREX wastes produced at the Hanford Site. BNFL and COGEMA HLW glasses are typically limited by heat generation or dose rate considerations to a maximum waste oxide loading of 25 to $30 \mathrm{wt} \%$ waste oxide, in contrast to the LTM and HTM glasses being developed at the Hanford Site where compositions are typically limited by the concentration of glass-limiting components $\left(\mathrm{Fe}_{2} \mathrm{O}_{3}, \mathrm{Cr}_{2} \mathrm{O}_{3}\right.$, or $\left.\mathrm{P}_{2} \mathrm{O}_{5}\right)$ in the waste. 


\section{Revision 0}

4.3.3.4 Radioactive Test Facilities at the Hanford Site. A small-scale, $1 \mathrm{~kg} / \mathrm{h}$ glass melter requires about 1.5 to $2.0 \mathrm{~L} / \mathrm{h}$ of feed with $10 \mathrm{wt} \%$ waste oxide. Small volumes of waste are typically transported between different areas of the Hanford Site using a bowling ball cask. The payload capacity of the cask is $1,130 \mathrm{~L}$, that would typically provide 10 to 15 days of continuous feed for the melter. Several hot cell facilities are also available at the Hanford Site (Howden 1993). In the 324 Building, a cleanup program is currently underway to refurbish and decontaminate B-cell where the RLFCM pilot plant was located. B-cell is the largest available cell in the 324 Building ( $7.6 \mathrm{~m} \times 6.7 \mathrm{~m} \times 9.2 \mathrm{~m}$ high), but under current plans, this facility will be closed by October 1998 .

The 325 Building high-level radiochemistry facility has three interconnecting hot cells with a total operating space of $16.2 \mathrm{~m}^{2}$. This facility also has three shielded vaults with various storage tanks and pumps to transfer wastes between the vaults and hot cells. A truck port and cask handling area are also available. A-cell is the largest cell in the 325 Building ( $2.1 \mathrm{~m} \mathrm{x} 4.6 \mathrm{~m} \times 4.6 \mathrm{~m} \mathrm{high}$ ) and could be used, along with several smaller cells, for laboratory or bench-scale testing of radioactive wastes. The shielded analytical laboratory is also located in the 325 Building and includes six interconnecting hot cells $\left(18.4 \mathrm{~m}^{2}\right)$ and two other cells with $5.3 \mathrm{~m}^{2}$ of space. Remote handing equipment is available for each cell. The 325 Building hot cell facility and equipment for testing radioactive core samples has been previously described by Morrey (1995). Other radioactive waste handling facilities may be found in B Plant, the waste encapsulation and storage facility (WESF), T Plant, the 222-S analytical laboratory, Z Plant and the unfinished fuels and materials examination facility (FMEF) in the 400 Area. 
WHC-SD-WM-TI-768

Revision 0

\subsection{FEED PROCESSABILITY}

This section provides general information on feed processability applicable to al the Hanford Site HLW. The HLW vitrification process consists of five major systems:

(1) melter and turntable assembly, (2) canister-handling system, (3) feed preparation system,

(4) liquid waste system, and (5) process offgas systems. The canister system has little impact on the feed processability or the performance of the melter. Melter performance characteristics were described in the previous section. In this section, glass formulation and glass composition constraints will be discussed in detailfor the processing and vitrification of the Hanford Site's defense HLW.

Melter feed compositions are expected to vary due to a wide range of compositions in the tanks, incomplete recovery and mixing of wastes, and differences from tank to tank. The corresponding glass composition will therefore vary for different waste types around a nominal glass composition for each waste. Changes in glass composition affect melt viscosity, electrical conductivity, and crystallization behavior. These properties determine the processability of the glass in a joule-heated melter. Glass composition also affects chemical durability and the related acceptability of the glass for the geologic repository. The optimum glass composition has to be determined for each waste before the waste is introduced to the melter. Glass composition control is important because it is difficult to process high-viscosity glasses through the melter or to correct the composition of canister glasses with unacceptable durability properties.

\subsection{WASTE FORM/WASTE FORM QUALIFICATION}

The reference waste form is assumed to be borosilicate glass. This assumption is based on several reviews that have recommended borosilicate glass in the past for the lowtemperature, joule-heated melter because of its durability and processability (DOE 1981 and 1990). In 1981, an independent peer review panel evaluated eight waste forms for the solidification and disposal of HLW. These waste forms were borosilicate glass, SYNROC, porous glass matrix, tailored ceramics, pyrolytic carbon and silica carbide-coated particles, concrete, metal matrices, and plasma spray coatings. Borosilicate glass was recommended based on its ability to immobilize a wide range of wastes, its insensitivity to radiation damage, and its thermal stability, chemical stability, and processability. For the HTM, sodium silicate and aluminum silicate glasses are being considered alternate waste forms based on improved WOL and chemical stability characteristics in relation to the standard borosilicate glass waste form.

Minimum requirements that waste forms must meet for acceptable geologic disposal are specified in the Waste Acceptance System Requirement Document (WASRD, DOE/RW-0351P, Rev. 2 to be issued March 1996) and Waste Acceptance Product Specifications for Vitrified High Level Waste Forms (WAPS.DOE/EM-0093, Rev. 1, May 1995). The WASRD is the senior requirements document that defines minimum 
requirements and associated limits for accepting immobilized high-level waste (IHLW) product in the proposed geologic repository. The WAPS establishes the minimum set of product requirements for the IHLW product. The main difference between WASRD, Rev.1 and the planned WASRD, Rev. 2 are: (1) DOE/Office of Civilian Radioactive Waste Management policy to accept spent HLW that does not include materials that are regulated as hazardous waste under the Resource Conservation and Recovery Act (RCRA) and (2) the concentration of plutonium should be less than $2,500 \mathrm{~g} / \mathrm{m}^{3}$ in each canister.

The current revision of the WAPS applicable to all waste glass producers was issued by the U.S. Department of Energy-Office of Environmental Restoration and Waste Management in May 1995 (DOE 1995). The WAPS are specific instructions for the producer to assure conformance with the WASRD. The WAPS are based on repository needs and waste form and canister requirements necessary to meet those needs. The waste acceptance process requires that the DOE-OCRWM function prepare WAPS's for each waste form. Table 5-1 briefly summarizes the principal WAPS for the DWPF (as derived from 10 CFR 60 and modified to reflect current standards for product consistency, phase stability, heat source, dose rate, and subcriticality).

The WAPS criteria are important because they represent the regulatory basis for glass composition control in the vitrification process. Because the existing WAPS are based on regulatory requirements or repository design considerations, they provide useful guidance for the development of nonborosilicate or low borosilicate glass waste forms such as soda-lime or aluminum silicate glasses under development for the HTM. The WAPS compliance will generally be demonstrated by process control of the vitrification process and by direct measurement of process and product variables. Because of remote operating conditions in the plant, direct measurements will be limited only to the most important process variables such as melter feed composition and glass product quality. Glass property models and process models will be used to predict product glass composition and properties necessary to process glass through the vitrification plant. The glass product consistency criterion for DWPF, for example, requires that the mean PCT results for each waste type be at least two standard deviations below mean PCT results of the EA glass. All future testing involving the PCT will use the EA glass as an internal control, that will facilitate direct demonstration of compliance with the product consistency specification (WAPS 1.3). No melter feed will be allowed to leave the Slurry Mix Evaporator (SME) at DWPF until it has been determined, from glass property models and testing, that the melter feed will make a product that will satisfy the WAPS 1.3 specification.

Waste producers are required to document their compliance with WAPS in the Waste Form Compliance Plan (WCP), the Waste Form Qualification Report (WQR), in the production records, and in the shipping and storage records. The WCP provides general information about the waste vitrification process and product, and a detailed description of the methods and programs by which the processor will demonstrate compliance with each specification in the WAPS. The WQR is a compilation of the results of those testing and analysis programs identified in the WCP. The main objective is to confirm the producers ability to produce a product that meets specifications. Parts of the WQR may be used to 


\section{Revision 0}

Table 5-1. Waste Acceptance Preliminary Specifications for the Defense Waste Processing Facility High-Level Waste Form.

\begin{tabular}{|c|c|c|}
\hline 1.1 & Chemical Composition & $\begin{array}{l}\text { Provide elemental and phase compositions (with ranges) for } \\
\text { life of facility for those components }>0.5 \mathrm{wt} \%\end{array}$ \\
\hline 1.2 & Radionuclide Inventory & $\begin{array}{l}\text { Provide canister radionuclide inventories of radionuclides } \\
\text { with half-lives longer than } 10 \text { years and concentrations } \\
>0.05 \mathrm{Ci} \text { up to } 1,100 \text { years after production }\end{array}$ \\
\hline 1.3 & Product Consistency & $\begin{array}{l}\text { PCTs performed for HLW to demonstrate compliance } \\
\text { glasses with reference standard DWPF EA glass }\end{array}$ \\
\hline 1.4 & Chemical and Phase Stability & $\begin{array}{l}\text { Report glass transition temperature (Tg) and time- } \\
\text { temperature-transformation ranges. After initial cooldown, } \\
\text { the waste should not exceed a temperature of } 400^{\circ} \mathrm{C} \text { during } \\
\text { storage }\end{array}$ \\
\hline 2.1 & Canister Material & Austenitic stainless steel \\
\hline 2.2 & Canister Fabrication and Closure & Leaktight according to ANSI N14.5-1987 \\
\hline 2.3 & Identification and Labeling & Alphanumeric code on each canister visible \\
\hline 3.1 & Free Liquid & None allowed in canister \\
\hline 3.2 & Gases & $\begin{array}{l}\text { None allowed in canister except helium, argon, air, and } \\
\text { other inerts. Internal pressure not to exceed } 7 \mathrm{lb} / \mathrm{ft}^{2} \text { gauge } \\
\text { at } 25{ }^{\circ} \mathrm{C}\end{array}$ \\
\hline 3.3 & $\begin{array}{l}\text { Explosives, Pyrophoricity and } \\
\text { Combustibility }\end{array}$ & None allowed \\
\hline 3.4 & Organic Materials & None allowed \\
\hline 3.5 & Free Volume & Less than 20 percent of canister volume \\
\hline 3.6 & External Contamination & $\begin{array}{l}\text { Less than } 220 \text { alpha } \mathrm{dpm} / 100 \mathrm{~cm}^{2} \text {, less than } 2,200 \\
\text { beta-gamma dpm } / 100 \mathrm{~cm}^{2}\end{array}$ \\
\hline 3.7 & Heat Generation & Less than $1,500 \mathrm{~W} /$ canister $+/-15$ percent \\
\hline 3.8 & Minimum Dose Rate & $\begin{array}{l}\text { Less than } 10^{5} \mathrm{rem} / \mathrm{h} \text { gamma and } 10 \mathrm{rem} / \mathrm{h} \text { neutron at } \\
\text { surface }\end{array}$ \\
\hline 3.9 & Chemical Compatibility & Document reactivity between waste and canister \\
\hline 3.10 & Subcriticality & $\mathrm{K}_{\mathrm{eff}}<0.90$ \\
\hline 3.13 & Handling Features & Provide grapple and canister with lifting flange \\
\hline 4.0 & Quality Assurance & $\begin{array}{l}\text { Provide quality assurance program complying with Office of } \\
\text { Geologic Repository/ DOE/RW- } 0214^{\mathrm{b}} \text { requirements }\end{array}$ \\
\hline
\end{tabular}

DWPF $=$ Defense Waste Processing Facility

EA = Environmental assessment

PCT = Product consistency test

ANSI, 1987, American National Standard for Radioactive Materials--Leakage Tests on Packages for Shipment, ANSI N14.5-1987, American National Standards Institute, New York, New York.

'DOE-OCRWM, 1990, Quality Assurance Requirements Document for the Civilian Radioactive Waste Management Program, DOE/RW-0214, U.S. Department of Energy-Office of Civilian Radioactive Waste Management, Washington, D.C. 
gain approval for startup, and may be used for licensing of a geologic repository for the canistered waste form.

\subsection{GLASS PROPERTY CONSTRAINTS/MELTER FEED COMPOSITION CONSTRAINTS}

Certain glass properties must be controlled to successfully process the glass through a joule-heated melter. Melter processing requirements have been developed for glass viscosity, electrical conductivity, and liquidus temperature. The WAPS. impose-limitations. on glass durability and require that chemical and phase stability information must be reported. The WAPS also specifies that neither liquid-liquid phase separation nor excessively volatile or corrosive secondary phases should occur in the product glass. Table 5-2 presents the glass property constraints developed for the HWVP melter. The WAPS specification now requires the 7-day PCT test in lieu of the 28-day MCC-1 test for durability (DOE 1995).

Table 5-2. Hanford Waste Vitrification Plant Glass Property Constraints.

\begin{tabular}{|l|c|c|}
\hline \multicolumn{1}{|c|}{ Component } & Lower bound & Upper bound \\
\hline REDOX: $\mathrm{Fe}^{+2} / \mathrm{Fe}^{+3}$ & 0.005 & 0.3 \\
\hline Viscosity: Pa-s at $1,150^{\circ} \mathrm{C}$ & 2 & 10 \\
\hline Electrical conductivity: S/cm at $1,150^{\circ} \mathrm{C}$ & 0.18 & 0.5 \\
\hline Phase behavior: liquidus temperature, ${ }^{\circ} \mathrm{C}$ & -- & $\begin{array}{c}100^{\circ} \mathrm{C} \text { below } \\
\text { nominal operating } \\
\text { temperature of melter }\end{array}$ \\
\hline $\begin{array}{l}\text { Durability: glass release } \\
\text { in g/m }{ }^{2} \text { for specific components } \\
\text { during 28-day MCC-1 test }\end{array}$ & -- & 28 \\
\hline
\end{tabular}

MCC = Materials Characterization Center

REDOX = Reduction oxidation.

In addition to properties necessary for control of the melter and durability of the glass, a second set of melter feed composition constraints was developed for the HWVP Project. The principal purpose of these constraints is to ensure that the melter feed compositions are restricted to the range where the glass property models are statistically valid and to provide a basis for evaluating process flowsheets, chemical additives, recycle streams, and operating conditions in the plant. To ensure that the glass product is acceptable, a CVS was conducted for the HWVP program to characterize the relationship between glass composition and glass and melt properties. The main objectives of the CVS were to: (1) develop empirical models relating the glass and melt properties to composition, (2) develop uncertainty equations for 


\section{Revision 0}

model predictions, and (3) develop a qualified composition region for acceptable HWVP melter processability and compliance with WAPS waste form qualification requirements.

The CVS glass composition region was selected for study based on the results of a previous series of scoping and solubility studies and on projections of glass compositions that might be made from the DST wastes to be processed in the HWVP. The acceptable glass composition region is currently defined in terms of the ten major oxide components in the feed, glass additives, and recycle streams, including silica $\left(\mathrm{SiO}_{2}\right)$, boric oxide $\left(\mathrm{B}_{2} \mathrm{O}_{3}\right)$, alumina $\left(\mathrm{Al}_{2} \mathrm{O}_{3}\right)$, iron oxide $\left(\mathrm{Fe}_{2} \mathrm{O}_{3}\right)$, zirconium oxide $\left(\mathrm{ZrO}_{2}\right)$, sodium oxide $\left(\mathrm{Na}_{2} \mathrm{O}\right)$, lithium oxide $\left(\mathrm{Li}_{2} \mathrm{O}\right)$, calcium oxide $(\mathrm{CaO})$, magnesium oxide $(\mathrm{MgO})$, and others (all. remaining waste components). A total of 124 glasses were evaluated in the CVS-I and CVS-II, Phases I, II, and III, with the following properties measured: viscosity and electrical conductivity $\left(950\right.$ to $1,250^{\circ} \mathrm{C}$ ), glass transition temperature, thermal expansion, crystallinity, and durability based on the MCC 28-day leach test, and the 7-day PCT. In addition, 21 other glasses were tested in CVS-II, Phase IV with only PCT and MCC-1 properties measured and 40 glasses in CVS-III, Phase I with measurements of viscosity, electrical conductivity, liquidus temperature and PCT durability. The CVS-III glasses were formulated for the high-temperature melter. Table 5-3 lists the composition ranges covered in the CVS-I and CVS-II studies and the general range over which the CVS-derived glass property models are considered to be useful and valid. It should not be assumed that all glass compositions within this region will necessarily yield an acceptable set of processing properties in the melter.

Table 5-3. Glass Composition Range Covered By Composition Variability Study (CVS-1 and CVS-2) Composition Region.

\begin{tabular}{|l|c|c|}
\hline \multicolumn{1}{|c|}{ Oxide component } & Lower bound (wt\%) & Upper bound (wt \%) \\
\hline $\mathrm{SiO}_{2}$ & 42 & 57 \\
\hline $\mathrm{B}_{2} \mathrm{O}_{3}$ & 5 & 20 \\
\hline $\mathrm{Al}_{2} \mathrm{O}_{3}$ & 0 & 17 \\
\hline $\mathrm{Fe}_{2} \mathrm{O}_{3}$ & 0.5 & 15 \\
\hline $\mathrm{ZrO}_{2}$ & 0 & 13 \\
\hline $\mathrm{Na}_{2} \mathrm{O}$ & 5 & 20 \\
\hline $\mathrm{Li}_{2} \mathrm{O}$ & 1 & 7 \\
\hline $\mathrm{CaO}$ & 0 & 10 \\
\hline $\mathrm{MgO}$ & 0 & 8 \\
\hline Others & 1 & 10 \\
\hline
\end{tabular}




\section{WHC-SD-WM-TI-768 \\ Revision 0}

\subsection{VISCOSITY}

Industrial glasses are typically processed at a viscosity of about $10 \mathrm{~Pa}-\mathrm{s}$ (100 poise) in commercial melters. This viscosity has been used for waste glass tests in pilot- and engineering-scale melters (Hagy et al. 1974, Chick et al. 1984). The viscosity of the waste glass should be maintained in the range of 2 to $10 \mathrm{~Pa}$-s for optimum melter performance. Glasses with viscosity lower than about $2 \mathrm{~Pa}$-s tend to penetrate into the melter refractory bricks and excessively corrode melter refractories. When glass viscosity is above about $10 \mathrm{~Pa}-\mathrm{s}$, melt rates become exceedingly low, glass becomes more difficult to pour from the melter, and such glasses may not form a consolidated monolith in the canisters.

Glass viscosity, as a function of temperature data, was modeled by: (1) the Arrheniustype equation,

$$
\ln \eta=\operatorname{sum}\left(\mathrm{A}_{\mathrm{Ai}} \mathrm{X}_{\mathrm{i}}\right)+\operatorname{sum}\left(\mathrm{B}_{\mathrm{Ai}} \mathrm{X}_{\mathrm{i}}\right) / \mathrm{T}\left(\mathrm{T} \text { in }{ }^{\circ} \mathrm{k}\right),
$$

where $\mathrm{X}_{\mathrm{i}}$ represents the oxide mass fraction of each component and $\mathrm{A}_{\mathrm{Ai}}$ and $\mathrm{B}_{\mathrm{Ai}}$ are the component coefficients $\left(R^{2}=0.9704\right)$; and (2) the Fulcher equation,

$$
\ln \eta=\operatorname{sum}\left(\mathrm{A}_{\mathrm{Fi}} \mathrm{X}_{\mathrm{i}}\right)+\operatorname{sum}\left(\mathrm{B}_{\mathrm{Fi}} \mathrm{X}_{\mathrm{i}}\right) /\left[\mathrm{T}-\operatorname{sum}\left(\mathrm{T}_{\mathrm{i}} \mathrm{X}_{\mathrm{i}}\right)\right]\left(\mathrm{T} \text { in }{ }^{\circ} \mathrm{C}\right),
$$

where $\mathrm{X}_{\mathrm{i}}$ represents the oxide mass fraction of each component and $\mathrm{A}_{\mathrm{Fi}}$ and $\mathrm{B}_{\mathrm{Fi}}$ and $\mathrm{T}_{\mathrm{i}}$ are the model coefficients $\left(R^{2}=0.9958\right)$. The $R^{2}$ terms are a measure of the statistical fit, with $\mathbf{R}^{2}=1.0$ representing a perfect fit of the statistical model to the experimental data. The Fulcher equation differs from the Arrhenius equation in that a temperature coefficient $T_{i}$ is added to represent the temperature at which viscosity approaches infinity. The Arrhenius equation predicts a linear relationship between In viscosity and inverse temperature. A question of practical interest is whether the simpler Arrhenius model (with 20 coefficients) adequately predicts viscosity compared to the more complicated Fulcher model (with 30 coefficients). The Fulcher model may be slightly better in the temperature range of interest for the LTM and HTM $\left(1,150\right.$ to $\left.1,450^{\circ} \mathrm{C}\right)$. Table 5-4 provides the CVS-derived Fulcher component coefficients $\mathrm{A}, \mathrm{B}$, and $\mathrm{T}_{\mathrm{i}}$ for the first-order viscosity model.

Generally, viscosity decreases with an increase in $\mathrm{Li}_{2} \mathrm{O}, \mathrm{Na}_{2} \mathrm{O}$, and $\mathrm{B}_{2} \mathrm{O}_{3}$ concentration, and increases with increased $\mathrm{SiO}_{2}, \mathrm{Al}_{2} \mathrm{O}_{3}$, and $\mathrm{ZrO}_{2}$ content. 
WHC-SD-WM-TI-768

Revision 0

Table 5-4. Fulcher First-Order Viscosity Model Coefficients A, B and $T_{i}$.

\begin{tabular}{|c|c|c|}
\hline Variable & Coefficient & Coefficient estimate \\
\hline $\mathrm{SiO}_{2}$ & A & -10.5899 \\
\hline $\mathrm{B}_{2} \mathrm{O}_{3}$ & $\mathrm{~A}$ & -24.4127 \\
\hline $\mathrm{Al}_{2} \mathrm{O}_{3}$ & $\mathrm{~A}$ & 1.4998 \\
\hline $\mathrm{Fe}_{2} \mathrm{O}_{3}$ & $\mathrm{~A}$ & -13.6326 \\
\hline $\mathrm{ZrO}_{2}$ & A & -0.3590 \\
\hline $\mathrm{Na}_{2} \mathrm{O}$ & $\mathrm{A}$ & 2.02 \\
\hline $\mathrm{Li}_{2} \mathrm{O}$ & $\mathrm{A}$ & 5.4558 \\
\hline $\mathrm{CaO}$ & $\mathrm{A}$ & 3.9535 \\
\hline $\mathrm{MgO}$ & $\mathrm{A}$ & 5.3088 \\
\hline Others & A & -2.3815 \\
\hline $\mathrm{SiO}_{2}$ & $\mathrm{~B}$ & 19236.3263 \\
\hline $\mathrm{B}_{2} \mathrm{O}_{3}$ & B & 15922.8410 \\
\hline $\mathrm{Al}_{2} \mathrm{O}_{3}$ & B & 9524.4388 \\
\hline $\mathrm{Fe}_{2} \mathrm{O}_{3}$ & $\mathrm{~B}$ & 14559.3344 \\
\hline $\mathrm{ZrO}_{2}$ & B & 4618.1457 \\
\hline $\mathrm{Na}_{2} \mathrm{O}$ & B & -12965.4177 \\
\hline $\mathrm{Li}_{2} \mathrm{O}$ & $\mathrm{B}$ & -39177.2042 \\
\hline $\mathrm{CaO}$ & $\mathrm{B}$ & -18671.4525 \\
\hline $\mathrm{MgO}$ & B & -11943.9611 \\
\hline Others & $\mathrm{B}$ & 1710.2061 \\
\hline $\mathrm{SiO}_{2}$ & $\mathrm{~T}_{1}$ & 76.1127 \\
\hline $\mathrm{B}_{2} \mathrm{O}_{3}$ & $\mathrm{~T}_{2}$ & 263.4849 \\
\hline $\mathrm{Al}_{2} \mathrm{O}_{3}$ & $\mathrm{~T}_{3}$ & 178.5252 \\
\hline $\mathrm{Fe}_{2} \mathrm{O}_{3}$ & $\mathrm{~T}_{4}$ & 43.6384 \\
\hline $\mathrm{ZrO}_{2}$ & $\mathrm{~T}_{5}$ & 540.5086 \\
\hline $\mathrm{Na}_{2} \mathrm{O}$ & $\mathrm{T}_{6}$ & 425.7163 \\
\hline $\mathrm{Li}_{2} \mathrm{O}$ & $\mathrm{T}_{7}$ & 474.4299 \\
\hline $\mathrm{CaO}$ & $\mathrm{T}_{8}$ & 1065.8248 \\
\hline $\mathrm{MgO}$ & $\mathrm{T}_{9}$ & 752.2421 \\
\hline Others & $T_{10}$ & 270.7406 \\
\hline
\end{tabular}




\subsection{ELECTRICAL CONDUCTIVITY}

In joule-heated melters, the electrical conductivity of the glass should be in the range of 0.18 to $0.5 \mathrm{~S} / \mathrm{cm}$ (or ohm ${ }^{-1} / \mathrm{cm}$ ) at $1,150^{\circ} \mathrm{C}$. In the DWPF melter, the acceptable range for electrical conductivity at $1,150{ }^{\circ} \mathrm{C}$ was estimated to be 0.36 to $1.1 \mathrm{~S} / \mathrm{cm}$ (Bickford et al. 1990). The current electrical conductivity range for the Hanford Site HLW melter has been extended to 0.1 to $1 \mathrm{~S} / \mathrm{cm}$ at $1,150^{\circ} \mathrm{C}$ (Hrma 1994). Glass must have electrical conductivity at melter operating temperatures at least two orders of magnitude higher than the refractory material in the melter walls. Such materials have never been known to have an electrical conductivity of more than $0.001 \mathrm{~S} / \mathrm{cm}$ at $1,150{ }^{\circ} \mathrm{C}$. Thus, $0.1 \mathrm{~S} / \mathrm{cm}$ appears to be a safe and acceptable lower limit for glass electrical conductivity. The upper limit of $1.0 \mathrm{~S} / \mathrm{cm}$ is an order of magnitude higher than the lower limit and in reasonably good agreement with the DWPF electrical conductivity estimate. If the electrical conductivity of the glass is too low, electrical shorting could occur through the melter's refractory, and larger power supply systems could be required due to higher voltages across the electrodes. High-electrical conductivities could result in excessively high-current densities across the electrodes and accelerated corrosion due to localized overheating of the electrodes.

Electrical conductivity, as a function of temperature data, was modeled as a simultaneous function of temperature and composition by expressing the Arrhenius equation coefficients as a first-order mixture model:

$$
\ln E=\operatorname{sum}\left(A_{i} X_{i}+B_{i} X_{i} / T\right)\left(T \text { in }{ }^{\circ} k\right),
$$

where $X_{i}$ represents the oxide mass fraction of each component, and $A_{i}$ and $B_{i}$ are component coefficients $\left(R^{2}=0.9582\right)$. Table 5-5 provides electrical conductivity Arrhenius equation coefficients $A$ and $B$.

Electrical conductivity is primarily affected by the concentration of alkaline oxides such as $\mathrm{Li}_{2} \mathrm{O}$ and $\mathrm{Na}_{2} \mathrm{O}$ in the glass while other components have little or no effect. Both $\mathrm{Li}_{2} \mathrm{O}$ and $\mathrm{Na}_{2} \mathrm{O}$ increase electrical conductivity, $\mathrm{Li}_{2} \mathrm{O}$ considerably more than $\mathrm{Na}_{2} \mathrm{O}$.

\subsection{LIQUIDUS TEMPERATURE}

Feed components that are not completely soluble in glass may cause melter operating problems and reduce the operable life of the melter. Insoluble or crystalline solids that are more dense than the melt could settle and produce a sludge layer on the floor of the melter. If the sludge is electrically conductive, current flow through the sludge could rapidly corrode electrodes and substantially reduce current densities and melting capacity. Solids could also clog the pour spout or increase the viscosity of the glass. 
WHC-SD-WM-TI-768

\section{Revision 0}

Table 5-5. Arrhenius Equation Electrical Conductivity Coefficients A and B.

\begin{tabular}{|c|c|c|}
\hline Variable & Coefficient & Coefficient estimate \\
\hline $\mathrm{SiO}_{2}$ & A & 8.12 \\
\hline $\mathrm{B}_{2} \mathrm{O}_{3}$ & A & 12.82 \\
\hline $\mathrm{Al}_{2} \mathrm{O}_{3}$ & A & 7.14 \\
\hline $\mathrm{Fe}_{2} \mathrm{O}_{3}$ & A & 9.94 \\
\hline $\mathrm{ZrO}_{2}$ & $\mathrm{~A}$ & 7.93 \\
\hline $\mathrm{Na}_{2} \mathrm{O}$ & A & 6.05 \\
\hline $\mathrm{Li}_{2} \mathrm{O}$ & A & 7.47 \\
\hline $\mathrm{CaO}$ & A & 14.41 \\
\hline $\mathrm{MgO}$ & A & 10.39 \\
\hline Others & A & 18.11 \\
\hline $\mathrm{SiO}_{2}$ & B & -10283 \\
\hline $\mathrm{B}_{2} \mathrm{O}_{3}$ & B & -15135 \\
\hline $\mathrm{Al}_{2} \mathrm{O}_{3}$ & B & -8227.18 \\
\hline $\mathrm{Fe}_{2} \mathrm{O}_{3}$ & $\mathrm{~B}$ & -10608 \\
\hline $\mathrm{ZrO}_{2}$ & B & -9723.86 \\
\hline $\mathrm{Na}_{2} \mathrm{O}$ & B & 7089.48 \\
\hline $\mathrm{Li}_{2} \mathrm{O}$ & $\mathrm{B}$ & 22484 \\
\hline $\mathrm{CaO}$ & $\bar{B}$ & -18769 \\
\hline $\mathrm{MgO}$ & B & -13414 \\
\hline Others & B & -20653 \\
\hline
\end{tabular}


The temperature where the first crystals precipitate in the glass is called the liquidus temperature $\left(T_{L}\right)$. The HWVP Project adopted the DWPF criteria for $T_{L}$, that specifies an upper limit of $1,050^{\circ} \mathrm{C}$. This is $100^{\circ} \mathrm{C}$ below the nominal operations temperature of the bulk glass and is intended to prevent precipitation of solids in the cooler zones of the melt pool. Only trace components such as insoluble noble metal oxides should be present in the melter if the glass is formulated to meet the liquidus temperature $\left(T_{L}\right)$ constraint. Liquidus temperature considerations are important because liquidus temperature is currently the limiting constraint for several of the Phase I feeds.

Liquidus temperature can be determined by heat-treating either crystal-free.or precrystallized samples of glass in a gradient-temperature furnace. An alternate method is to anneal the glass at $1,050{ }^{\circ} \mathrm{C}$ for 24 hours to induce crystallization at the liquidus temperature limit and from this determine whether the actual liquidus temperature is above or below this threshold.

Useful information also can be derived from canister centerline cooling (CCC) tests in which samples are taken through a predetermined cooling profile to replicate thermal conditions at the canister centerline. Crystals formed during CCC tests provide insight as to the likely phases that would form during cooling in the canister. Crystalline phases in the glass are characterized by optical microscopy with transmitted and reflected light, X-ray diffraction, and scanning electron microscopy with energy dispersive spectroscopy (SEM/EDS) to identify crystalline phases and to determine semiquantitatively the volume fraction of such crystals.

The major crystalline phases identified during the CVS were spinel phases (iron, nickel, chromium), lithium silicate, clinopyroxene (calcium, iron, and magnesium silicates), zircon (zirconium silicate), silica, nepheline (sodium aluminum silicate) and eucriptite (lithium aluminum silicate). Noble metals, mostly $\mathrm{RuO}_{2}$, were present as undissolved particles and sometimes as small needles with metallic particles of $\mathrm{Ru} / \mathrm{Rh}$ surrounded by layers of $\mathrm{Pd} / \mathrm{Ag} / \mathrm{Te}$ alloy. In some glasses, spinel phases and other crystals were nucleated on $\mathrm{RuO}_{2}$.

Spinel structures are represented by the formula $\mathrm{M}^{\mathrm{II}} \mathrm{M}_{2}^{\mathrm{III}} \mathrm{O}_{4}$, where $\mathrm{M}^{\mathrm{II}}$ consists of divalent $\mathrm{Fe}, \mathrm{Mg}$, or $\mathrm{Mn}$ and $\mathrm{M}^{\mathrm{III}}$ tri-valent $\mathrm{Fe}, \mathrm{Cr}$, or $\mathrm{Al}$.

The liquidus temperatures for spinel, clinopyroxene, and zirconium-containing crystals were statistically fit to a limited number of CVS glasses, using a first-order mixture model of the form:

$$
\mathrm{T}_{1}=\operatorname{sum}\left(\mathrm{B}_{\mathrm{i}} \mathrm{X}_{\mathrm{i}}\right)
$$

where: $\quad X_{i}$ represents the mass fraction of each major oxide in the glass

$B_{i}$ is the component coefficient. 


\section{Revision 0}

Table 5-6 summarizes the first-order model coefficients and range of measured liquidus temperatures for CVS glasses (Kim and Hrma 1995).

Table 5-6. Component Coefficients for First-Order Model of Liquidus Temperature.

\begin{tabular}{|l|c|c|c|}
\hline \multicolumn{1}{|c|}{ Component } & Clinopyroxene & Spinel phases & Zirconium crystals \\
\hline $\mathrm{SiO}_{2}$ & 855.65 & 989.31 & 753.78 \\
\hline $\mathrm{B}_{2} \mathrm{O}_{3}$ & 314.72 & 666.42 & 1095.83 \\
\hline $\mathrm{Al}_{2} \mathrm{O}_{3}$ & 1319.48 & 1735.03 & 1138.06 \\
\hline $\mathrm{Fe}_{2} \mathrm{O}_{3}$ & 1506.69 & 2256.00 & 1461.04 \\
\hline $\mathrm{ZrO}_{2}$ & 1844.50 & 928.11 & 4541.99 \\
\hline $\mathrm{Na}_{2} \mathrm{O}$ & 38.83 & 3.77 & 74.31 \\
\hline $\mathrm{Li}_{2} \mathrm{O}$ & -207.05 & -128.77 & -956.39 \\
\hline $\mathrm{CaO}$ & 1372.44 & 1366.21 & 886.76 \\
\hline $\mathrm{MgO}$ & 2387.62 & 2830.58 & 2458.47 \\
\hline Others & 1357.40 & 1005.56 & 657.99 \\
\hline $\mathrm{R}^{2}$ & 0.905 & 0.643 & 0.79 \\
\hline Measured $\mathrm{T}_{1}$ range & 761 to $969^{\circ} \mathrm{C}$ & 800 to $1,129{ }^{\circ} \mathrm{C}$ & 856 to $1.129{ }^{\circ} \mathrm{C}$ \\
\hline
\end{tabular}

The clinopyroxene model provides a good statistical fit to the experimental data, but this model is relatively unimportant because clinopyroxene crystals form at low temperatures and as such are unlikely to affect melter performance. For spinel phase crystals, the statistical fit is relatively poor based on the $28 \mathrm{CVS}$ glasses used to develop this model. The fit for the liquidus temperature of zirconium-containing crystals is reasonably good $\left(\mathrm{R}^{2}=\right.$ 0.79 ), although three different crystals are included in the model (zircon, sodium-zirconium silicate, and zirconium oxide). A better fit might be obtained if a sufficient amount of data were available to develop a separate model for each crystal form. The zirconium model also may have some predictive capability at higher temperatures because the model predicts, for all six CVS glasses in which zirconium crystals were found at the maximum operating temperature limit of the gradient temperature furnace $\left(1,129^{\circ} \mathrm{C}\right)$, liquidus temperatures above $1,129^{\circ} \mathrm{C}$. Judging from the size of the coefficients in the zirconium and spinel models, alkali oxides $\left(\mathrm{Li}_{2} \mathrm{O}\right.$ and $\left.\mathrm{Na}_{2} \mathrm{O}\right)$ should depress the liquidus temperature with $\mathrm{Li}_{2} \mathrm{O}$ having the strongest effect. Boric oxide, $\mathrm{CaO}$, and $\mathrm{Al}_{2} \mathrm{O}_{3}$ should have little effect on the liquidus temperature of zirconium-containing glasses while $\mathrm{ZrO}, \mathrm{MgO}$, and $\mathrm{Fe}_{2} \mathrm{O}_{3}$ may have a significant effect on such glasses. 


\section{Revision 0}

Recently, the predicted trends for $\mathrm{B}_{2} \mathrm{O}_{3}, \mathrm{NaO}_{2}$, and $\mathrm{Li}_{2} \mathrm{O}$ were experimentally confirmed for spinel phases and zirconium crystals in high-waste-oxide-loaded NCAW glasses (Kim and Hrma 1994). Figure 5-1 shows the comparison between predicted liquidus temperature of the zirconium-containing phase and measured liquidus temperatures and primary phases in CVS glasses. Figure 5-2 depicts a similar comparison between measured and predicted liquidus temperature of spinel. In CVS-I and II, only 10 of 124 glasses were found to have spinel liquidus temperatures above $1,050^{\circ} \mathrm{C}$. Nine of these glasses had more than $10 \mathrm{wt} \% \mathrm{Fe}_{2} \mathrm{O}_{3}$, which suggests that iron has a significant effect on the precipitation of spinel in borosilicate glass. Twenty-three of $40 \mathrm{CVS}$-III glasses had spinel liquidus temperatures above $1,050^{\circ} \mathrm{C}$ All of these glasses were very low boron or.non-borosilicate glasses, which suggests that boron also has a large effect on the liquidus temperature of spinel.

Figure 5-1. Predicted Versus Measured Liquidus Temperature of Zr-Containing Crystals for the First-Order Mixture Model.

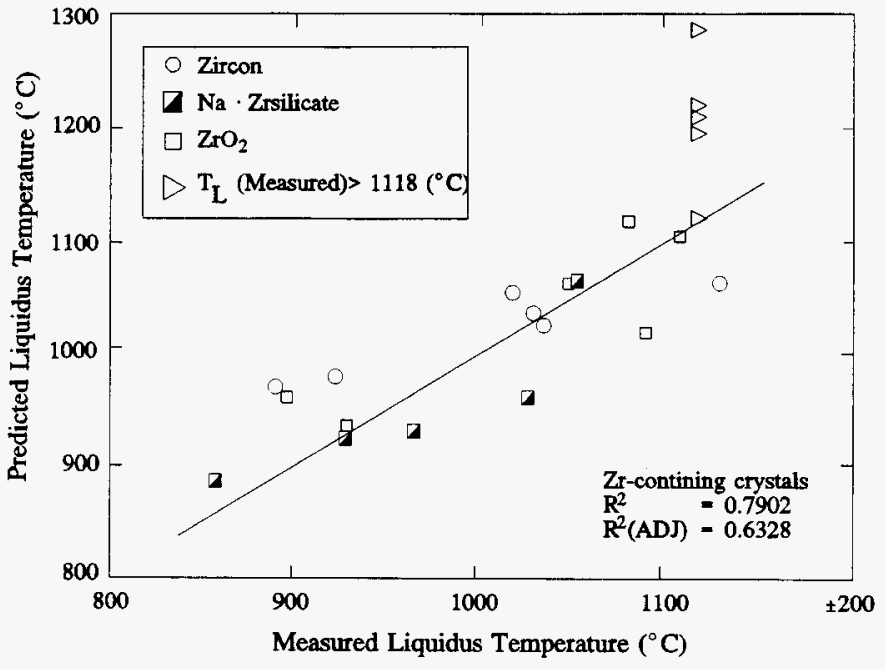




\section{Revision 0}

Figure 5-2. Predicted Versus Measured Liquidus Temperature of Spinel Phases in Composition Variability Study Glasses Based on First-Order Mixture Model.

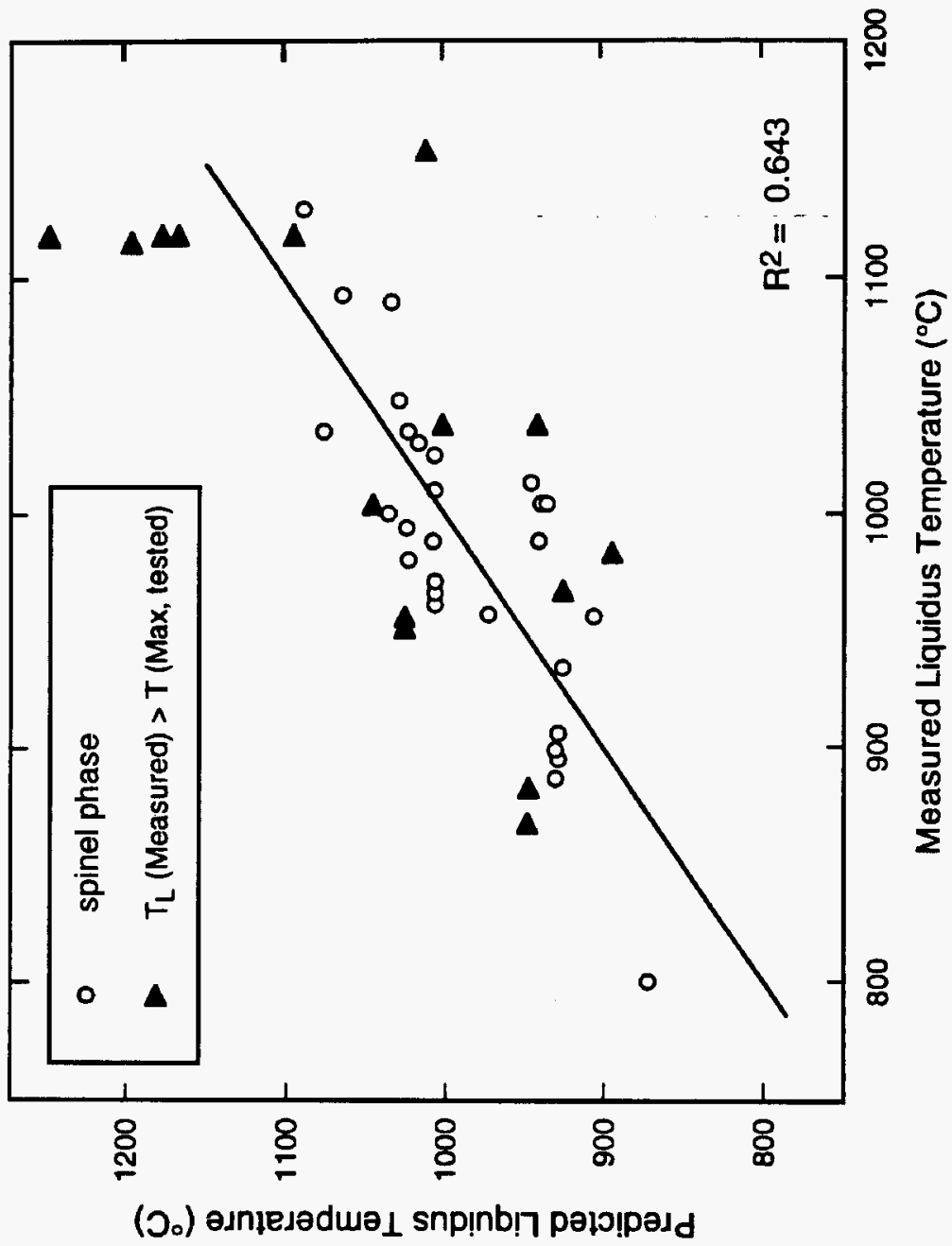


Spinels in HLW glasses normally contain iron, chromium, and nickel associated as elemental oxides in magnetite $\left(\mathrm{Fe}_{3} \mathrm{O}_{4}\right)$, chromite $\left(\mathrm{FeCr}_{2} \mathrm{O}_{4}\right)$, and trevorite $\left(\mathrm{NiFe}_{2} \mathrm{O}_{4}\right)$. Magnetite is the spinel phase most commonly found in CVS glasses with nickel and chromium as minor components. Melter operating temperatures and REDOX conditions have a strong thermodynamic influence on the form of iron in the melt (magnetite or hematite, $\mathrm{Fe}_{2} \mathrm{O}_{3}$ ). Crystallization is a kinetically dependent process in that some crystalline phases may be thermodynamically favored but may not be present because their crystallization rate is too low. Spinel phases crystallize rapidly in glass but dissolves very slowly after they precipitate.

Another approach developed for liquidus temperature prediction is the phase-equilibria liquidus temperature model (Ecole Polytechnique). This model uses a set of equations describing the thermodynamic properties of glass as functions of temperature and composition based on phase diagrams and thermodynamic data for binary and ternary systems. A quasichemical model (QCM) was developed to represent the thermodynamic properties of the glass as a function of composition and temperature. The QCM can be used to predict the Gibbs free energy of the multicomponent liquid using optimized parameters derived from available phase data. The output of the model includes $T_{L}$ and the primary crystalline phase, equilibrium crystallization at temperatures below $\mathrm{T}_{\mathrm{L}}$ (including fractions and activities of all crystalline phases considered) and metastable $\mathrm{T}_{\mathrm{L}}$ with suppression of crystallization of the primary phase. For a given glass, the model predicts one or more possible primary phases with the corresponding liquidus temperature. The first phase may not be present in the glass because of slow kinetics (slow crystallization rate or low concentration of components in the melt). The experimentally derived primary phase agreed with the predicted first phase in 31 of 89 CVS glasses tested, agreed with the predicted second or third phase in 20 glasses, and showed no agreement in the remaining 38 glasses. When the measured versus predicted liquidus temperatures were compared for the 89 CVS glasses, the statistical fit was found to be very poor $\left(R_{2}=0.431\right)$. For spinel liquidus temperature prediction, agreement was satisfactory in some cases and poor in others. When measured versus predicted liquidus temperatures for spinel phases were compared, the average temperature deviation was $68^{\circ} \mathrm{C}$.

Still another model is the liquidus temperature spinel model developed for SRS glasses (Jantzen 1991). This model is based on the free energy of formation of the liquidus phases such as spinel and nepheline. The model assumes that the liquidus temperature of spinel is proportional to a pseudo-equilibrium constant given by the following equation: 


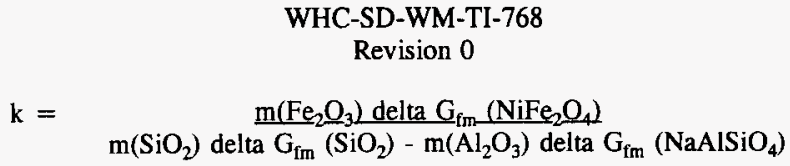

where: $\quad m\left(\mathrm{Fe}_{2} \mathrm{O}_{3}\right), \mathrm{m}\left(\mathrm{SiO}_{2}\right)$, and $\mathrm{m}\left(\mathrm{Al}_{2} \mathrm{O}_{3}\right)$ are mole fractions

delta $\mathrm{G}_{\mathrm{fm}}$ is the free energy of formation of $\left(\mathrm{NiFe}_{2} \mathrm{O}_{4}\right)-134 \mathrm{kcal} / \mathrm{mole},\left(\mathrm{SiO}_{2}\right)$ $-156 \mathrm{kcal} / \mathrm{mole}$, and $\left(\mathrm{NaAlSiO}_{4}\right)-360 \mathrm{kcal} / \mathrm{mole}$.

For SRS glasses, $\mathrm{R}_{2}=0.77$, when $\mathrm{T}_{1}=\mathrm{A}+\mathrm{BK}, \mathrm{A}=803.6^{\circ} \mathrm{C}$, and $\mathrm{B}=227{ }^{\circ} \mathrm{C}$. When this model is applied to CVS glasses, the statistical fit is very poor $\left(R^{2}=0.178\right)$ partially because CVS glasses were not used to develop this model. It appears this model is not useful for glasses with large variations in major component concentration such as those from the Hanford Site.

\subsubsection{Model Refinements During 1996}

New models were developed in 1996 for estimating the liquidus temperature of spinel. These models are derived from liquidus temperature measurements of 61 CVS glasses, 19 Savannah River glasses and 11 Phase I glasses (see Tables 6-2, 6-3, and 6-4 for the estimated composition and properties of the Phase I glasses). The liquidus temperature of spinel was statistically fit to first and second-order mixture models of the form:

$$
\begin{aligned}
& T_{L}=\operatorname{sum}\left(b_{i} X y_{i}\right) \quad \text { First-order model }\left(R^{2}=0.845\right) \\
& T_{L}=\operatorname{sum}\left(c_{i} X y_{j}\right)+\operatorname{sum}\left(d_{i} X y_{i} X z_{i}\right) \quad \text { Second-order model }\left(R^{2}=0.9488\right)
\end{aligned}
$$

where: $\quad T_{L}$ is the liquidus temperature in ${ }^{\circ} \mathrm{C}$.

$y_{i}$ and $z_{i}$ represent the mass fractions of each major oxide and minor oxides such as $\mathrm{Cr}_{2} \mathrm{O}_{3}$ and $\mathrm{NiO}$ in the glass. terms.

$b_{i}, c_{i}$ and $d_{i}$ are single and mixed component coefficients for the first and second order

Table 5-7 provides the statistically derived component coefficients for the first and second-order models, while Table 5-8 compares the measured and estimated liquidus temperatures for the Phase I glasses and a selected group of CVS and Savannah River glasses with the poorest fit based on the first-order model (more than $50{ }^{\circ} \mathrm{C}$ above or below the measured $\mathrm{T}_{\mathrm{L}}$. 
The root mean square deviation between predicted and measured $T_{L}$ for this group of samples is $53{ }^{\circ} \mathrm{C}$ for the first-order model and $25.5^{\circ} \mathrm{C}$ for the second-order model.

Predictive performance can be evaluated by comparing these models to glasses that were not used to develop the models. PNNL is currently developing another set of 36 glasses from which they will obtain liquidus temperature measurements for testing validity of current models. These glasses are of special interest because they were formulated around a spinelforming baseline composition (similar to the Phase I nom-3 glass), with targeted variations in $\mathrm{Al}_{2} \mathrm{O}_{3}, \mathrm{~B}_{2} \mathrm{O}_{3}, \mathrm{Cr}_{2} \mathrm{O}_{3}, \mathrm{Fe}_{2} \mathrm{O}_{3}, \mathrm{Li}_{2} \mathrm{O}, \mathrm{MgO}, \mathrm{MnO}, \mathrm{Na}_{2} \mathrm{O}$, and $\mathrm{SiO}_{2}$ to measure the effect of each component on the liquidus temperature of spinel. Results of this investigation may not be available until the end of FY 1996. This study is important because it is the first study to systematically evaluate the effects of chromium, nickel and manganese.

Spinel phase and zirconium oxides and silicates are the crystalline phases most often observed in CVS glasses at high temperature $\left(1,050^{\circ} \mathrm{C}\right)$. The best liquidus temperature models appear to be the CVS-derived, first-order model for zirconium-containing crystals, and the statistically-derived second-order model for spinel. Spinel is clearly the dominate phase of concern in the melter because of low zirconium concentration in the Phase I feeds. However, nepheline, and potentially eucriptite $\left(\mathrm{LiAlSi}_{2} \mathrm{O}_{6}\right)$, are the most important phases in the canistered glass. The precipitation of nepheline during canister centerline cooling is commonly associated with poor durability results from the PCT test. The second-order spinel model, however, is especially important because this model allows one to predict the crystallization behavior of glasses in the melter. This spinel model, together with other property models such as the ones for viscosity, durability, and nepheline can be used to estimate the maximum WOL and limiting glass composition of the Phase I feeds. 


\section{WHC-SD-WM-TI-768}

Revision 0

Table 5-7. First and Second-Order Spinel Liquidus Temperature Model Coefficients B, C, and D.

\begin{tabular}{|c|c|c|c|c|}
\hline Variable & Coefficient & First-order model & Coefficient & Second-order model \\
\hline $\mathrm{SiO}_{2}$ & B & 1247.477 & $\mathrm{C}$ & -3252.578 \\
\hline $\mathrm{B}_{2} \mathrm{O}_{3}$ & B & 266.961 & $\mathrm{C}$ & 1913.452 \\
\hline $\mathrm{Na}_{2} \mathrm{O}$ & B & -654.105 & $\mathrm{C}$ & 671.302 \\
\hline $\mathrm{Li}_{2} \mathrm{O}$ & B & -2004.931 & $\mathrm{C}$ & -778.785 \\
\hline $\mathrm{CaO}$ & B & 920.331 & $\mathrm{C}$ & 3921.812 \\
\hline $\mathrm{MgO}$ & B & 1947.495 & $\mathrm{C}$ & -3978.842 \\
\hline $\mathrm{Fe}_{2} \mathrm{O}_{3}$ & B & 2118.935 & $\mathrm{C}$ & 2206.712 \\
\hline $\mathrm{Al}_{2} \mathrm{O}_{3}$ & B & 2084.204 & $\mathrm{C}$ & 3052.081 \\
\hline $\mathrm{ZrO}_{2}$ & B & 2672.485 & $\mathrm{C}$ & 1934.87 \\
\hline $\mathrm{Bi}_{2} \mathrm{O}_{3}$ & B & 876.592 & $\mathrm{C}$ & 2331.235 \\
\hline $\mathrm{Cr}_{2} \mathrm{O}_{3}$ & B & 14956.243 & C & 37497.11 \\
\hline $\mathrm{MnO}$ & B & 1092.062 & $\mathrm{C}$ & 23637.442 \\
\hline $\mathrm{NiO}$ & $\mathrm{B}$ & 4463.781 & $\mathrm{C}$ & 3531.782 \\
\hline $\mathrm{P}_{2} \mathrm{O}_{5}$ & B & 1006.421 & $\mathrm{C}$ & 3116.844 \\
\hline Others & B & 911.304 & $\mathrm{C}$ & 1971.079 \\
\hline $\mathrm{SiO}_{2} \times \mathrm{xiO}_{2}$ & & & $\mathrm{D}$ & 6325.440 \\
\hline $\mathrm{CaOxCaO}$ & & & $\mathrm{D}$ & -16731.47 \\
\hline $\mathrm{MgOxB}_{2} \mathrm{O}_{3}$ & & & $\mathrm{D}$ & 26612.647 \\
\hline $\mathrm{MgOxLi}_{2} \mathrm{O}$ & & & $\mathrm{D}$ & 82967.224 \\
\hline $\mathrm{Fe}_{2} \mathrm{O}_{3} \times \mathrm{Fe}_{2} \mathrm{O}_{3}$ & & & $\mathrm{D}$ & 8336.89 \\
\hline $\mathrm{ZrO}_{2} \times \mathrm{Al}_{2} \mathrm{O}_{3}$ & & & $\mathrm{D}$ & 36523.126 \\
\hline $\mathrm{Cr}_{2} \mathrm{O}_{3} \times \mathrm{Cr}_{2} \mathrm{O}_{3}$ & & & $\mathrm{D}$ & $-1.584 \mathrm{E} 6$ \\
\hline $\mathrm{MnOxSiO}_{2}$ & & & $\mathrm{D}$ & -38271.46 \\
\hline $\mathrm{R}^{2}$ & 0.845139 & & 0.948884 & \\
\hline $\mathrm{R}^{2}$ (adjusted) & 0.816612 & & 0.932346 & \\
\hline
\end{tabular}




\section{Revision 0}

Table 5-8. Comparison of Measured to Predicted Spinel Liquidus Temperatures for Phase I Glasses and Selected Group of CVS and Savannah River Glasses.

\begin{tabular}{|c|c|c|c|}
\hline Glass & $\mathrm{T}_{\mathrm{L}}$ measured, ${ }^{\circ} \mathrm{C}$ & $\begin{array}{l}\mathrm{T}_{\mathrm{L}} \text { predicted, }{ }^{\circ} \mathrm{C} \\
\text { first-order model }\end{array}$ & $\begin{array}{c}\mathrm{T}_{\mathbf{L}} \text { predicted, }{ }^{\circ} \mathrm{C} \\
\text { second-order model }\end{array}$ \\
\hline Nom-2* & 1,009 & 983 & 990 \\
\hline Nom-3* & 1,047 & 1,017 & 1,053 \\
\hline Nomc-1* & 1,005 & 1,047 & 1,042 \\
\hline Nomc-2* & 998 & 996 & 998 \\
\hline C106A-2* & 1,004 & 1,035 & 1,011 \\
\hline C106A-3* & 1,029 & 999 & 979 \\
\hline C106A-4* & 885 & 943 & 927 \\
\hline C106B-1* & 986 & 941 & 999 \\
\hline C106B-2* & 894 & 902 & 877 \\
\hline $\mathrm{AZ}-3^{*}$ & 1,048 & 1,017 & 1,026 \\
\hline $\mathrm{AZ}-5^{*}$ & 953 & 971 & 956 \\
\hline CVS1-19 & 961 & 1,017 & 989 \\
\hline CVS1-20 & 966 & 1,017 & 988 \\
\hline CVS2-30 & 1,090 & 1,017 & 1,052 \\
\hline CVS2-42 & 1,093 & 1,020 & 1,060 \\
\hline CVS2-46 & 1,004 & 926 & 1,009 \\
\hline CVS2-51 & 899 & 971 & 921 \\
\hline CVS2-56 & 1,117 & 1,039 & 1,110 \\
\hline CVS2-92 & 905 & 852 & 916 \\
\hline CVS2-97 & 887 & 971 & 921 \\
\hline CVS3-9 & 1,374 & 1,308 & 1,348 \\
\hline CVS3-13 & 1,295 & 1,242 & 1,266 \\
\hline CVS3-18 & 1,293 & 1,238 & 1,310 \\
\hline CVS3-24 & 1,127 & 1,092 & 1,118 \\
\hline $\mathrm{AH}-168 \mathrm{AL}$ & 897 & 819 & 864 \\
\hline
\end{tabular}

*Phase I glass described in Tables 6-2, 6-3, and 6-4. 


\subsection{DURABILITY}

The durability of borosilicate glass is the property defining radionuclide release from the waste form. The intrusion of groundwater into and through a geologic repository is the most likely mechanism for transporting radionuclides into the biosphere. Thus, it is important that nuclear waste glasses be stable in the presence of groundwater over the geologic time scale.

The Product Consistency Test (PCT) has been developed for assessing the product acceptability in relation to the selected standard EA glass. The.P.T, , which uses a crushed sample of glass, is sensitive to glass composition and homogeneity and can be performed in a remote environment with radioactive or hazardous glasses because of simple sample preparation and test procedures. The test can be performed in only 7 days. Crushed glass, preferably of 100 to 200 mesh at the recommended ratio of $10 \mathrm{Ml}$ of solution to $1 \mathrm{~g}$ of glass, is immersed in American Society for Testing and Materials Type-1 water for a minimum of 7 days at $90^{\circ} \mathrm{C}$. Leachates are filtered and analyzed for $\mathrm{Ph}$ and elemental concentrations of interest. Results are reported as normalized elemental releases of

$$
r_{i}=m_{i} /\left(F_{i} A\right)
$$

where: $\quad r_{i}$ is the mass release of element $\mathrm{i}\left(\mathrm{g} / \mathrm{m}^{2}\right)$

$\mathrm{m}_{\mathrm{i}}$ is the mass of the $\mathrm{i}$-th element in solution $(\mathrm{g})$

$F_{j}$ is the $i$-th element mass fraction in glass

A is the sample surface area $\left(\mathrm{m}^{2}\right)$.

The WAPS was revised in 1993 and once again in 1995 (DOE 1995) and now requires the normalized release of boron, lithium, and sodium determined by the PCT to be less than the release of these elements from the DWPF EA glass. Normalized boron, lithium, and sodium release values for EA glass have been determined and reported by DWPF (Technical Bases for the DWPF Glass Product Control Program, WSRC-IM-91-116-5, Rev. 1, Plodinec 1995). The EA glass dissolution rates for these elements are shown in Table 5-9. At DWPF, the product acceptance standards require that the mean PCT results for each waste type be at least two standard deviations below the mean PCT results of the EA glass. All future testing involving the PCT will use the EA glass as an internal control that will facilitate direct demonstration of compliance with the product consistency specification (WAPS 1.3).

The effect of crystallization on high-aluminum (5.6 and $11.1 \mathrm{wt} \%$ ) glass and high-iron borosilicate glass was studied using the MCC-1 and Corning ${ }^{l}$ Glass Works tests (Jantzen and Bickford 1985). These studies concluded that formation of a $\mathrm{Ni}, \mathrm{Fe}$, spinel phase

\footnotetext{
'Corning is a trademark of Corning Glass Works.
} 


\section{WHC-SD-WM-TI-768}

\section{Revision 0}

$\left(\mathrm{NiFe}_{2} \mathrm{O}_{4}\right)$ had little or no effect on leachability and the formation of 10 to $20 \mathrm{vol} \%$ acmite $\left(\mathrm{Na}_{2} \mathrm{O}-\mathrm{Fe}_{2} \mathrm{O}_{3}-4 \mathrm{SiO}_{2}\right)$ produced a 12 to 23 percent increase in glass dissolution as measured by PCT (Jantzen 1984). When MCC-1 tests were conducted on a glass of lower alumina content (SRL-165 glass with high iron, $2.2 \mathrm{wt} \% \mathrm{Al}_{2} \mathrm{O}_{3}$ and $6.5 \mathrm{wt} \% \mathrm{~B}_{2} \mathrm{O}_{3}$ ), boron releases were found to increase by a factor of 10 after heat treatment (crystallization) (Jantzen and Bickford 1985). This may indicate the possible crystallization of nepheline $\left(\mathrm{NaAlS}_{2} \mathrm{O}_{6}\right)$ in the Savannah River 165 glass, that would lead to the depletion of aluminum and the loss of durability in the matrix glass. These effects have been observed with certain CVS glasses (CVS2-63, CVS2-33). The precipitation of eucriptite $\left(\mathrm{LiAlSi}_{2} \mathrm{O}_{6}\right)$ also reduces the amount of aluminum in the matrix glass and (Exnar 1995). Eucriptite crystals have previously precipitated from borosilicate glass with 16.4 to $24.6 \mathrm{wt} \% \mathrm{Al}_{2} \mathrm{O}_{3}$ and 5.9 to $6.5 \mathrm{wt} \% \mathrm{Li}_{2} \mathrm{O}$.

Table 5-9. Environmental Assessment Glass Dissolution Rates.*

\begin{tabular}{|l|c|c|}
\hline \multicolumn{1}{|c|}{ Property } & Normalized Release, $\mathrm{g} / \mathrm{m}^{2}$ & Standard Deviation, $\mathrm{g} / \mathrm{m}^{2}$ \\
\hline Boron & 8.35 & 0.61 \\
\hline Lithium & 4.785 & 0.37 \\
\hline Sodium & 6.675 & 0.45 \\
\hline
\end{tabular}

*In deionized water, product consistency test ( 7 day, $\left.A / \mathrm{V}=2000 \mathrm{~m}^{-1}\right)$. Averages and standard deviations are pooled values from six data sets. 


\section{WHC-SD-WM-TI-768 \\ Revision 0}

Figure 5-3 compares the normalized boron release from quenched and canister centerline cooled (CCC) glasses in the CVS database. This comparison is important because it shows the effect of crystallization on the durability of the canister centerline glass. The effect of crystallization varies with the type and volume percent crystals in the glass. The precipitation of nepheline, crystobalite $\left(\mathrm{SiO}_{2}\right)$ or eucriptite $\left(\mathrm{LiAlSi}_{2} \mathrm{O}_{6}\right)$ during $\mathrm{CCC}$ cooling . causes a substantial increase in normalized boron release (compared to quenched samples of the same composition). For specific compositions of interest, one should refer to CVS2-16, CVS2-33, CVS2-35, CVS2-63, and CVS2-85 for nepheline precipitation, CVS2-78, CVS2-79 and CVS2-80 for crystobalite, and CVS2-68 and CVS2-80 for eucriptite. Other crystals exert a minor to moderate affect on durability, including hematite $\left(\mathrm{Fe}_{2} \mathrm{O}_{3}\right)$,clinopyroxene and zircon, while lithium silicate $\left(\mathrm{Li}_{2} \mathrm{SiO}_{3}\right)$ actually causes a decrease in boron release (increase in durability) due to the removal of lithium from the matrix glass. The adverse affects of nepheline and eucriptite precipitation are caused, as stated earlier, by the removal of aluminum from the matrix glass.

Figure 5-3. Comparison of Normalized Boron Release From Quenched and Canister Centerline Cooled Glass.

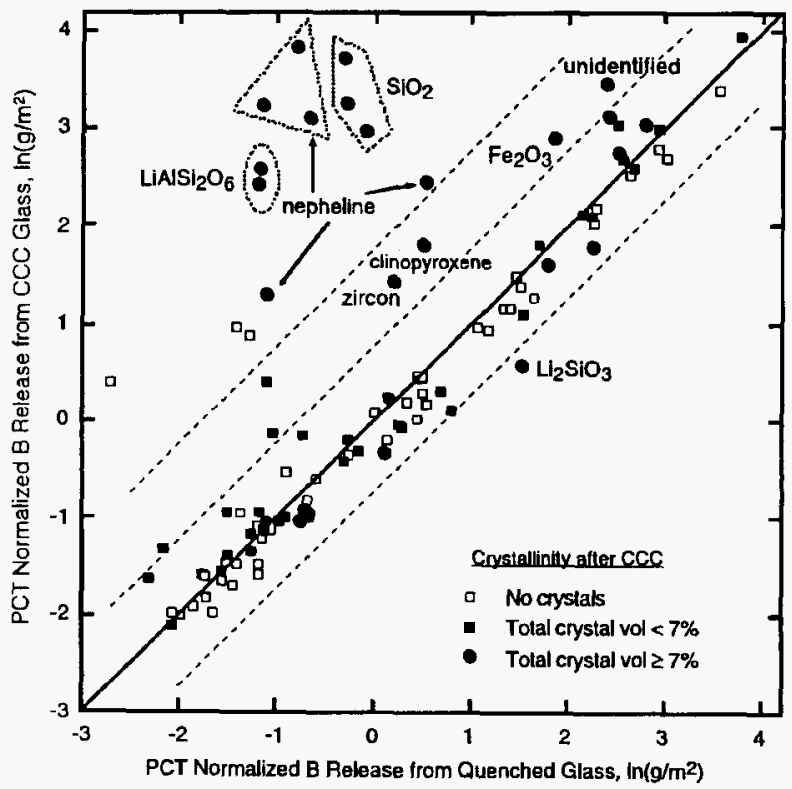


As part of the FY 1996 glass work, PNNL evaluated potential Phase I glass compositions for impact of nepheline precipitation during glass cooling. PNNL compared nepheline precipitation data from the relatively complex $\mathrm{HLW}$ glasses with the published ternary phase diagram for the $\mathrm{Na}_{2} \mathrm{O}-\mathrm{Si}_{2} \mathrm{O}-\mathrm{Al}_{2} \mathrm{O}_{3}$ system.

The phase diagram for the $\mathrm{Na}_{2} \mathrm{O}-\mathrm{Al}_{2} \mathrm{O}_{3}-\mathrm{SiO}_{2}$ system is shown in Figure 5-4. The central area of this diagram depicts the composition region where nepheline is expected to form. Figure 5-5 provides a plot of the normalized canister centerline cooled glass compositions where $\mathrm{Na}_{2} \mathrm{O}, \mathrm{Al}_{2} \mathrm{O}_{3}$ and $\mathrm{SiO}_{2}$ have been normalized to the sum of the three components. The open circles represent glasses that formed nepbeline_(in quenched or canister centerline cooled samples), while the closed points represent glasses that did not form nepheline during $\mathrm{CCC}$ cooling. In almost every case, the nepheline points reside in the nepheline designated area of the phase diagram. Only 1 of 27 nepheline forming glasses (CVS3-16) resides outside the nepheline area, while only 2 of 157 CVS and Phase I glasses (including C106B-1) that did not form nepheline reside inside of the nepheline area. The composition of the CVS3-16 glass was altered by the precipitation of corundum $\left(\mathrm{Al}_{2} \mathrm{O}_{3}\right)$ that changed the matrix composition into one that rests in the nepheline region.

Studies are currently underway to map the nepheline composition region with 13 newly formulated glasses and to reevaluate the nepheline forming behavior of the Savannah River PUREX glass. Since many of these glasses have different melting temperatures, the canister centerline cooling curves are also being adjusted to compensate for these differences. The nepheline region in the phase diagram is approximately defined by the following limits:

1. $0.43<\mathrm{SiO}_{2}<0.62$

2. $\mathrm{Al}_{2} \mathrm{O}_{3}<1.67 * \mathrm{Na}_{2} \mathrm{O}$

3. $\mathrm{Al}_{2} \mathrm{O}_{3}<0.28$

4. $\mathrm{Al}_{2} \mathrm{O}_{3}+0.57 * \mathrm{SiO}_{2}>0.43$

where $\mathrm{Na}_{2} \mathrm{O}, \mathrm{Al}_{2} \mathrm{O}_{3}$ and $\mathrm{SiO}_{2}$ are mass fractions of each component normalized to the sum of the three components. The nepheline region can be avoided by defining a minimum limit for $\mathrm{SiO}_{2}$ such that glasses with a normalized $\mathrm{SiO}_{2}$ content $\geq 0.62$ should not be susceptible to nepheline precipitation in the canister. Based on recent tests, the minimum $\mathrm{SiO}_{2}$ limit may be reduced to 0.6 as more progress is made in determining the composition ranges where nepheline precipitation could be a problem. The defined limits for nepheline are especially important for certain wastes, such as Tank 241-C-106 waste, where the WOL limits are likely to be determined by the nepheline forming characteristics of the glass. 
WHC-SD-WM-TI-768

Revision 0

Figure 5-4. $\mathrm{Na}_{2} \mathrm{O}-\mathrm{Al}_{2} \mathrm{O}_{3}-\mathrm{SiO}_{2}$ Phase Diagram

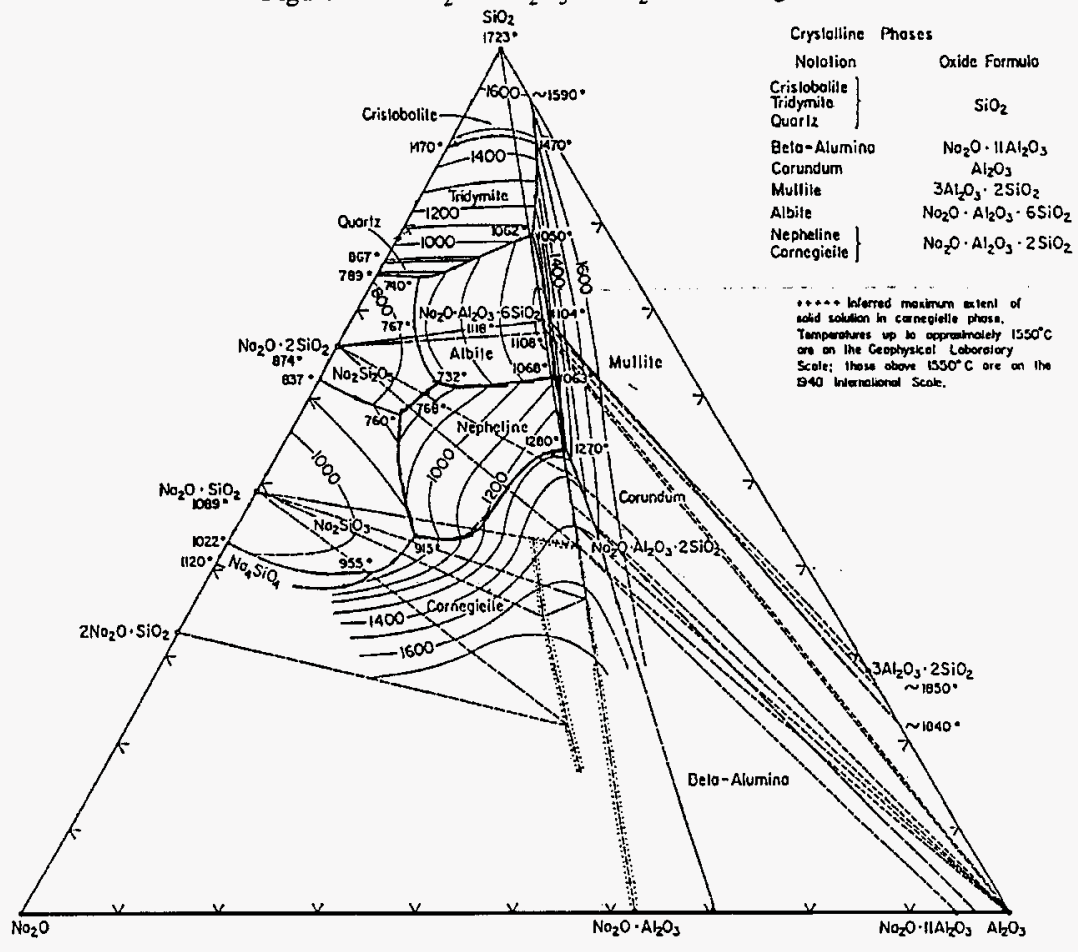




\section{Revision 0}

Figure 5-5. Nepheline Region in $\mathrm{Na}_{2} \mathrm{O}-\mathrm{Al}_{2} \mathrm{O}_{3}-\mathrm{SiO}_{2}$ Phase Diagram

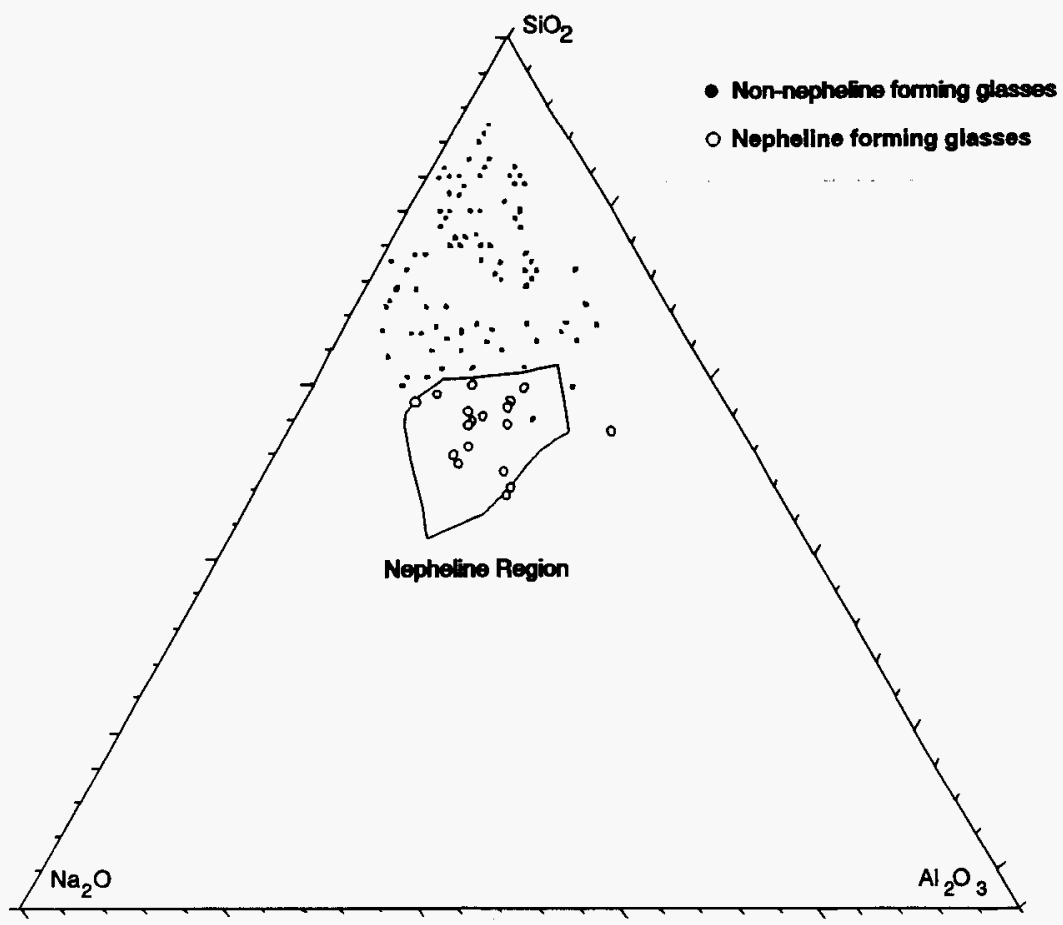


It is not clear if nepheline laden glasses would be acceptable to the repository because of the significant inventory of crystals and nonuniform distribution of properties in the canistered glass. Also with slower annealing, nepheline laden glasses could easily fail the PCT durability criteria. During the DWPF Waste Qualification Runs, the maximum amount of crystallinity was found to be $5.6 \mathrm{vol} \%$ ( $1.9 \mathrm{vol} \%$ spinel and $3.7 \mathrm{vol} \%$ acmite- $\mathrm{NaFeSi}_{2} \mathrm{O}_{6}$ ) (WP-14, canister S00155, WSRC-IM-91-116-5, Plodinec et al. 1996). The PCT results for maximum crystallinity samples were within 5 to 6 percent of the results for quenched samples from the same canister height, thus demonstrating the general uniformity of the DWPF glass (Table 11, WSRC-IM-91-116-5). The waste producer is currently required to report all of the crystalline phases in the glass (WAPS 1.1) and to determine the effect of any phase changes, from the WAPS 1.1 baseline conditions, on the PCT response of the borosilicate glass (WAPS 1.4). However, the WAPS criteria do not specifically address crystallinity limits in the glass, in terms of induced stress limits or performance assessment characteristics of the crystal laden glass. Nor do the WAPS criteria provide any guidance as to the proper course to take in formulating high-waste-oxide-loaded glasses that may produce crystals in the melter or during canister cooling.

In Figure 5-6, normalized sodium and silica releases are shown as a function of NCAW WOL. This figure is instructive because it shows that the release of sodium does not increase until NCAW WOLs approach about $70 \mathrm{wt} \%$ in glass. Figure 5-7 illustrates the effect of aluminum oxide on normalized boron release from CVS glasses and the relative effect of changing the aluminum oxide content in the standard HW39-4 glass. This correlation shows that aluminum oxide has a significant effect on PCT (short-term) durability in that normalized boron releases are reduced as aluminum oxide content is raised in borosilicate glasses. Generally, it has been found that glass durabilities increase with increasing concentrations of $\mathrm{Al}_{2} \mathrm{O}_{3}, \mathrm{ZrO}_{2}$, and $\mathrm{SiO}_{2}$ in glass (with aluminum oxide having the dominate effect) and decrease with increasing concentrations of $\mathrm{Li}_{2} \mathrm{O}, \mathrm{Na}_{2} \mathrm{O}, \mathrm{B}_{2} \mathrm{O}_{3}$, and $\mathrm{MgO}$.

These roles can be explained by considering structural effects in glass. The addition of $\mathrm{Na}_{2} \mathrm{O}$ interrupts the silica-oxygen-silica bonds that form the glass network by converting these bonds into relatively weak non-bridging oxygen (NBO) bonds. When $\mathrm{Al}_{2} \mathrm{O}_{3}$ is added, the durability of the glass is improved because the NBO bonds are converted into stronger aluminum to oxygen bonds. Other components such as $\mathrm{ZrO}_{2}, \mathrm{Fe}_{2} \mathrm{O}_{3}$, and $\mathrm{B}_{2} \mathrm{O}_{3}$ also improve the durability of glass by reducing the number of $\mathrm{NBO}$ bonds (with the relative binding strength to alkalis being $\mathrm{Al}_{2} \mathrm{O}_{3}>\mathrm{ZrO}_{2}>\mathrm{Fe}_{2} \mathrm{O}_{3}>\mathrm{B}_{2} \mathrm{O}_{3}>\mathrm{CaO}$ ). Structurally, $\mathrm{Al}_{2} \mathrm{O}_{3}$, $\mathrm{ZrO}_{2}, \mathrm{Fe}_{2} \mathrm{O}_{3}, \mathrm{~B}_{2} \mathrm{O}_{3}$, and $\mathrm{SiO}_{2}$ are considered network formers and $\mathrm{Na}_{2} \mathrm{O}, \mathrm{Li}_{2} \mathrm{O}, \mathrm{K}_{2} \mathrm{O}, \mathrm{Rb}_{2} \mathrm{O}$, and $\mathrm{Cs}_{2} \mathrm{O}$ network breakers, with several of these components having an ambivalent role depending on the relative concentration of NBO bonds in the glass network. For LLW glasses (with $20 \mathrm{wt} \% \mathrm{Na}_{2} \mathrm{O}$ ), the most durable compositions contain from 9 to $12 \mathrm{wt} \% \mathrm{Al}_{2} \mathrm{O}_{3}$ and 6 to $9 \mathrm{wt} \% \mathrm{~B}_{2} \mathrm{O}_{3}$ (Kim 1995). 
Figure 5-6. Effect of Neutralized Current Acid Waste Loading on 7-Day Product Consistency Test Normalized Element Sodium and Silicon Releases.

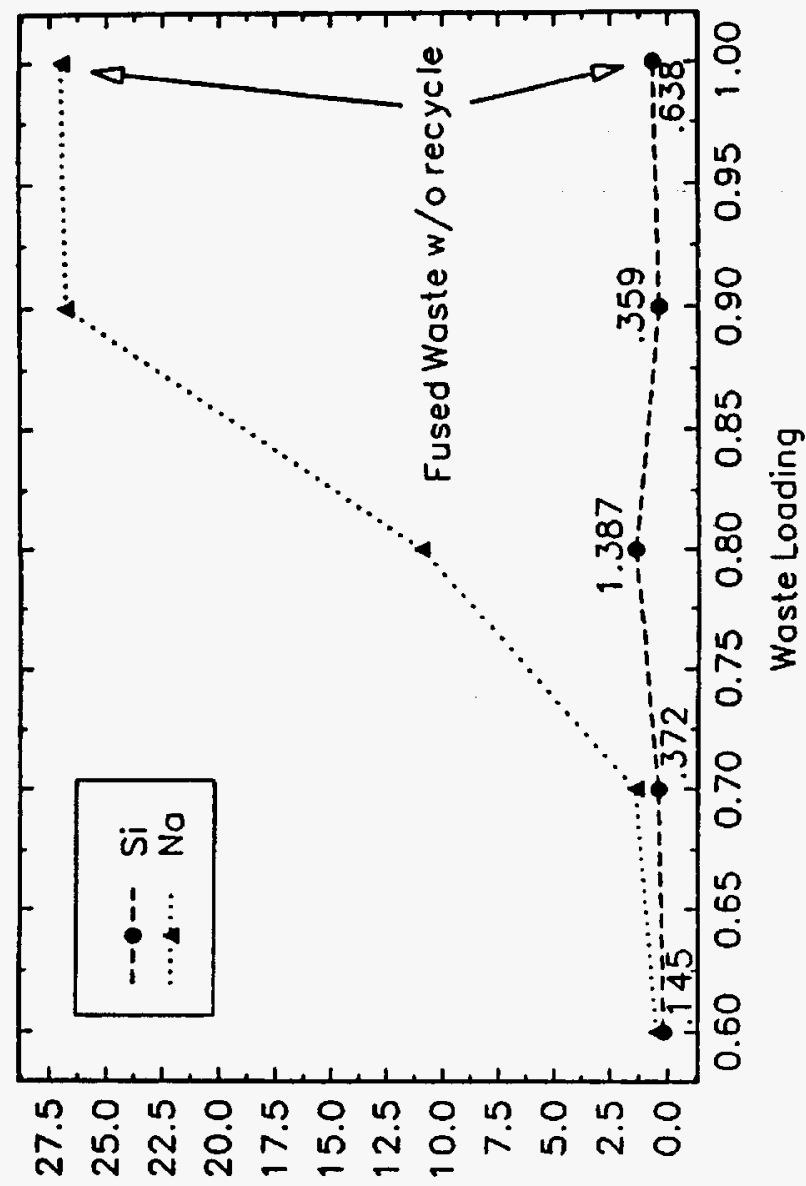

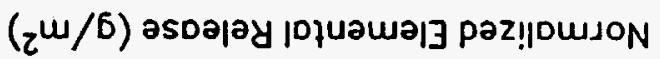




\section{Revision 0}

Figure 5-7. Effect of Aluminum Oxide on Normalized Boron Release from Composition Variability Study and HW39-4 Glasses.

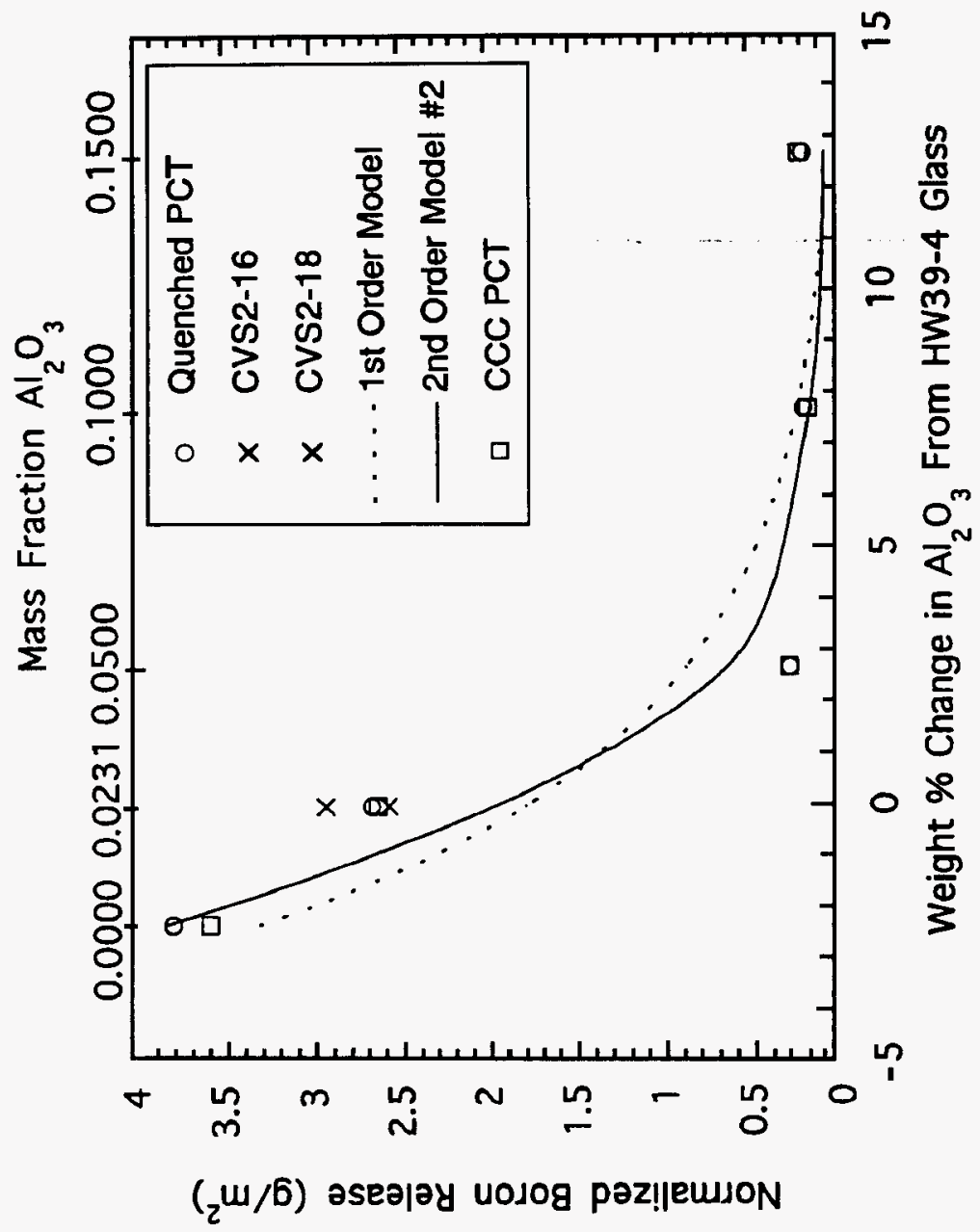


Second-order mixture models of the form $\ln r=\operatorname{sum~} a_{i} X y_{i}+$ sum $c_{i} X y_{i} X z_{i}$, where $a_{i}$, $c_{i}$ and $y_{i}, z_{i}$ are the single and mixed component coefficients and mass fractions, respectively, were fitted to the natural logs of the averaged silicon, boron, lithium, and sodium elemental release data from CVS-I and CVS-II, Phases I, II, and III, glasses. The elemental release coefficients for second-order model \#3 are shown in Table 5-10 based on the results of a 7-day PCT.

Judging from the relative value of the coefficients, alumina, sodium, and lithium oxides seem to have a dominant effect on durability properties of borosilicate glass. For nonborosilicate glass compositions developed for the HTM,.durability.is less important as a composition constraint because high-temperature glasses are usually much more durable than the reference EA glass.

\subsection{GLASS SOLUBILITY CONSTRAINTS}

Some minor components are relatively insoluble in borosilicate glass. The most important of these from a waste composition perspective are chromium oxide and phosphate. Other minor components such as chloride, fluoride, and sulfate also have very low solubility in HLW glass. Uranium and bismuth are known to be present in significant concentration in SST wastes, but the solubility limit and component interaction effects of these components have not been fully determined in borosilicate glass. Noble metals (including silver and tellurium) in the Phase I wastes are expected to be a concern in flat-bottom melters and should be limited to ensure an acceptable melter operating life. Titanium oxides may be important because such materials may be used as cesium absorbers to remove cesium from the LLW stream. These materials with captured cesium can be added to HLW feed for ultimate disposal. In this section, minor component solubility limits for HLW glass will be discussed. These limits are expected to have a significant impact on glass composition, maximum WOL constraints for certain wastes, and melter operations.

\subsubsection{Chromium Oxide Solubility}

Chromium ${ }^{\mathrm{III}}$ and $\mathrm{Cr}^{\mathrm{VI}}$ are both present in borosilicate glass, with $\mathrm{Cr}^{\mathrm{III}}$ being the dominant and most stable oxidation state of chromium. Chromium ${ }^{\text {III }}$ oxide has poor solubility in borosilicate glass because of its high-melting temperature $\left(1,900{ }^{\circ} \mathrm{C}\right)$ and poor miscibility with $\mathrm{SiO}_{2}$. The solubility of $\mathrm{Cr}_{2} \mathrm{O}_{3}$ increases with increasing temperature and increasing alkali metal content in the glass (Volf 1984). In most commercial glasses, the $\mathrm{Cr}_{2} \mathrm{O}_{3}$ solubility limit is about $2 \mathrm{wt} \%$ based on physical property constraints of the glass. If the ratio of $\mathrm{Cr}^{\mathrm{VI}} / \mathrm{Cr}^{\mathrm{III}}$ in the glass melt increases to 0.01 , alkaline chromates tend to separate from the glass. Under these conditions, the alkaline chromates will concentrate in a yellow surface layer where they are relatively soluble leading to poor durability characteristics in the glass (Sussmilch and Jouan 1993). Chromates are preferentially formed in glasses with high-alkali-metal content (basic glasses). Because of REDOX considerations, the amount of $\mathrm{Cr}^{6+}$ in a molten glass should be negligibly small at temperatures greater than $1,000{ }^{\circ} \mathrm{C}$. 
WHC-SD-WM-TI-768

Revision 0

Table 5-10. Coefficients for Second-Order Model ( $\# 3$ ) of Natural Logarithm of Average 7-Day Product Consistency Test

Normalized Elemental Releases $\left(\mathrm{g} / \mathrm{m}^{2}\right)$.

\begin{tabular}{|c|c|c|c|c|}
\hline Component & PCT silicon & PCT boron & PCT lithium & PCT sodium \\
\hline $\mathrm{SiO}_{2}$ & -2.3415 & -4.1267 & -3.3159 & -1.7652 \\
\hline $\mathrm{B}_{2} \mathrm{O}_{3}$ & 2.2959 & -2.7803 & 12.4446 & -10.4721 \\
\hline $\mathrm{Al}_{2} \mathrm{O}_{3}$ & -28.9796 & -39.6897 & -37.6244 & -32.6424 \\
\hline $\mathrm{Fe}_{2} \mathrm{O}_{3}$ & -5.6296 & -0.7342 & -5.5866 & -2.8512 \\
\hline $\mathrm{ZrO}_{2}$ & -17.2431 & -21.8129 & -10.3597 & 16.1412 \\
\hline $\mathrm{Na}_{2} \mathrm{O}$ & 17.8263 & 19.7648 & 16.3850 & 12.5007 \\
\hline $\mathrm{Li}_{2} \mathrm{O}$ & 18.0258 & 25.1279 & 16.9458 & 7.5967 \\
\hline $\mathrm{CaO}$ & 11.2689 & 7.8944 & 20.5631 & 8.5246 \\
\hline $\mathrm{MgO}$ & -1.7491 & -51.2479 & 12.1879 & -17.0361 \\
\hline Others & -2.5487 & 4.3558 & -19.0889 & 0.7069 \\
\hline $\mathrm{Al}_{2} \mathrm{O}_{3} \times \mathrm{Al}_{2} \mathrm{O}_{3}$ & 96.5647 & 105.2815 & 99.7873 & 89.9973 \\
\hline $\mathrm{SiO}_{2} \times \mathrm{MgO}$ & & 119.5209 & & 57.6768 \\
\hline $\mathrm{Na}_{2} \mathrm{O} \times \mathrm{ZrO}_{2}$ & & 70.4225 & & \\
\hline $\mathrm{CaO} \times \mathrm{ZrO}_{2}$ & 95.2066 & 101.8736 & & \\
\hline $\mathrm{B}_{2} \mathrm{O}_{3} \times \mathrm{CaO}$ & & -80.9291 & -119.8254 & -96.6209 \\
\hline $\mathrm{Na}_{2} \mathrm{OxCaO}$ & & -90.8996 & -120.7020 & \\
\hline $\mathrm{MgOxZrO}_{2}$ & 109.7168 & 146.7060 & & \\
\hline $\mathrm{Na}_{2} \mathrm{O} \mathrm{Al}_{2} \mathrm{O}_{3}$ & -53.2773 & & & \\
\hline $\mathrm{B}_{2} \mathrm{O}_{3} \times \mathrm{Na}_{2} \mathrm{O}$ & -40.6487 & & & \\
\hline $\mathrm{SiO}_{2} \times \mathrm{CaO}$ & -43.2976 & & & \\
\hline $\mathrm{Li}_{2} \mathrm{O} \mathrm{MgO}$ & & & 165.6870 & \\
\hline $\mathrm{MgOxAl}_{2} \mathrm{O}_{3}$ & & & -153.5615 & \\
\hline $\mathrm{Fe}_{2} \mathrm{OxAl}_{2} \mathrm{O}_{3}$ & & & 82.5595 & \\
\hline $\mathrm{Na}_{2} \mathrm{OxLi} \mathrm{i}_{2} \mathrm{O}$ & & & & 152.3524 \\
\hline $\mathrm{SiO}_{2} \times \mathrm{ZrO}_{2}$ & & & & -53.2743 \\
\hline $\mathrm{Li}_{2} \times \mathrm{Al}_{2} \mathrm{O}_{3}$ & & & & -86.3851 \\
\hline $\mathrm{B}_{2} \mathrm{O}_{3} \times \mathrm{B}_{2} \mathrm{O}_{3}$ & & 76.5449 & & 94.9874 \\
\hline $\mathrm{R}^{2}$ & 0.8471 & 0.9106 & 0.9058 & 0.9238 \\
\hline
\end{tabular}

PCT $=$ Product consistency test. 


\section{Revision 0}

Also, there does not appear to be any evidence of chromate molten salt segregation in chromium rich, low-level waste glasses formed at 1,150 and $1,450^{\circ} \mathrm{C}$ ( $\mathrm{Li} \mathrm{1995).}$

A single-component study was recently performed to assess the effect of adding chromium ( 0 to 2 wt $\% \mathrm{Cr}_{2} \mathrm{O}_{3}$ ) to $\mathrm{HW} 39$ reference borosilicate glass (with $11.1 \mathrm{wt} \% \mathrm{Fe}_{2} \mathrm{O}_{3}$ ) (Bates and Bowen 1987). In general, chromium was found to have only a very minor effect on viscosity and electrical conductivity, and it had no material effect on the physical or leachability properties of the glass. The only significant effect was an increase in the amount of crystalline material in the melt in direct proportion to the $\mathrm{Cr}_{2} \mathrm{O}_{3}$ concentration above $0.5 \mathrm{wt} \%$. Crystalline material was not observed in the glass with $0 \mathrm{wt} \% \mathrm{Cr}_{2} \mathrm{O}_{3}$. As the $\mathrm{Cr}_{2} \mathrm{O}_{3}$ concentration increased from 0.5 to $2.0 \mathrm{wt} \%$, an appreciable amount of crystalline material ( 1 to $5 \mathrm{wt} \%$ ) was formed. The $\mathrm{Cr}_{2} \mathrm{O}_{3}$ solubility limit appears to be about $0.5 \mathrm{wt} \%$ in HW39 glass (at $1,150^{\circ} \mathrm{C}$ ), consistent with earlier HWVP, DWPF, and WVDP studies of other borosilicate glasses. Cubic $\mathrm{Fe}, \mathrm{Cr}$ spinel $\left(\mathrm{FeCr}_{2} \mathrm{O}_{4}\right)$ crystals, about $5 \mu$ in diameter, were the only crystals observed above $1.0 \mathrm{wt} \% \mathrm{Cr}_{2} \mathrm{O}_{3}$. Between 0.5 and $1.0 \mathrm{wt} \% \mathrm{Cr}_{2} \mathrm{O}_{3}$ platelets of the sesquioxide $(\mathrm{FeCr})_{2} \mathrm{O}_{3}$ of about $35 \mu$ in size were also present with spinel in the glass.

In the CVS, slightly different results were obtained. Chromium oxide crystals with sharp facets were observed after the canister centerline cooling test in one sample with $0.89 \mathrm{wt} \% \mathrm{Cr}_{2} \mathrm{O}_{3}$ (CVS2-55) but not in other samples with up to $0.72 \mathrm{wt} \% \mathrm{Cr}_{2} \mathrm{O}_{3}$ (CVS2-56 and -57). These samples also contained only $7.33 \mathrm{wt} \% \mathrm{Fe}_{2} \mathrm{O}_{3}$, that might explain the somewhat higher $\mathrm{Cr}_{2} \mathrm{O}_{3}$ solubility limit in these glasses compared to $\mathrm{HW} 39$ glass (11.1 wt \% $\mathrm{Fe}_{2} \mathrm{O}_{3}$ ). Spinel phases have only rarely precipitated in CVS borosilicate glasses with less than $10 \mathrm{wt} \% \mathrm{Fe}_{2} \mathrm{O}_{3}$ at temperatures above $1,050{ }^{\circ} \mathrm{C}$. The sample with $0.89 \mathrm{wt} \% \mathrm{Cr}_{2} \mathrm{O}_{3}$ had a liquidus temperature of $944^{\circ} \mathrm{C}$.

Chromium solubility limits were also measured in two low-level waste (LLW) glasses being developed by Pacific Northwest Laboratory (Li 1995). For LLW glasses L6-5412 and L4-9012, the solubility limits were found to be 0.48 and $1.04 \mathrm{wt} \% \mathrm{Cr}_{2} \mathrm{O}_{3}$, respectively, at $1,350{ }^{\circ} \mathrm{C}$. The L6-5412 and L4-9012 LLW glasses are nearly identical in composition (56.78 wt $\% \mathrm{SiO}_{2}, 12$ wt $\% \mathrm{Al}_{2} \mathrm{O}_{3}, 0$ wt $\% \mathrm{Fe}_{2} \mathrm{O}_{3}$, and $20 \mathrm{wt} \% \mathrm{Na}_{2} \mathrm{O}$ ), except that $\mathrm{L} 6-5412$ contains $5 \mathrm{wt} \% \mathrm{~B}_{2} \mathrm{O}_{3}$ and $\mathrm{L} 4-90129 \mathrm{wt} \% \mathrm{~B}_{2} \mathrm{O}_{3}$. For aluminum silicate glasses such as $\mathrm{HTB} 651$, the solubility limit appears to be $0.8 \mathrm{wt} \% \mathrm{Cr}_{2} \mathrm{O}_{3}$ at $1,350{ }^{\circ} \mathrm{C}$ ( $\mathrm{Li} \mathrm{1995)}$ ). Spinel phases tend to crystallize from HTB65l when the temperature is reduced to $1,245^{\circ} \mathrm{C}$.

Chromium solubility limits have also been determined for high temperature borosilicate glasses that melt at temperatures from 1,314 to $1,328^{\circ} \mathrm{C}$ (Vojtech et al. 1995). X-ray, SEM, and optical microscopy were used to identify $\mathrm{Cr}_{2} \mathrm{O}_{3}$ rich precipitates (eskolaite and spinel) in quenched and in thermally annealed samples with $1.1 \mathrm{wt} \% \mathrm{Cr}_{2} \mathrm{O}_{3}$ and varying amounts of $\mathrm{Fe}_{2} \mathrm{O}_{3}, \mathrm{MnO}, \mathrm{NiO}$, and $\mathrm{ZrO}_{2}$. Crystals were observed in four of five samples at their nominal melting temperature, and in all samples annealed for 24 hours $100{ }^{\circ} \mathrm{C}$ below the nominal melting temperature of the glass. The matrix glasses (uncrystallized portion of the sample) contained from 0.6 to $0.93 \mathrm{wt} \% \mathrm{Cr}_{2} \mathrm{O}_{3}$, with the highest level of matrix chrome being found in a glass with $2.5 \mathrm{wt} \% \mathrm{MnO}_{2}$ (compared to $0.7 \mathrm{wt} \% \mathrm{MnO}$ in the other 
samples). These results are important because they show that the solubility of $\mathrm{Cr}_{2} \mathrm{O}_{3}$ is only marginally increased by the temperature and composition of borosilicate and aluminum silicate glasses.

During melter studies, chromium rich spinel phases have commonly formed in glasses with 1.3 to $1.6 \mathrm{wt} \% \mathrm{Cr}_{2} \mathrm{O}_{3}$, but not in glasses with as little as $0.2 \mathrm{wt} \% \mathrm{Cr}_{2} \mathrm{O}_{3}$. Because of their small size, most spinel phases tend to remain in the melt. Settling can occur when these crystals form larger agglomerates. The settling characteristics of spinel phases were examined during a PSCM test. The melter feed contained $1.3 \mathrm{wt} \% \mathrm{Cr}_{2} \mathrm{O}_{3}$ but about 5 percent of the $\mathrm{Cr}_{2} \mathrm{O}_{3}$ in the feed precipitated to the bottom of the melter. (Perez.and Nakaoka 1986). The product glass had a $\mathrm{Cr}_{2} \mathrm{O}_{3}$ concentration of $1.18 \mathrm{wt} \%$ while the bottom $2.5 \mathrm{~cm}$ of glass in the melter was found to contain $18.3 \mathrm{wt} \% \mathrm{Cr}_{2} \mathrm{O}_{3}$ with some agglomerates as large as $80 \mu$. In the bottom section of the melter where the precipitates had settled, the glass matrix material contained $0.52 \mathrm{wt} \% \mathrm{Cr}_{2} \mathrm{O}_{3}$. This matrix concentration was found to be consistent with the $\mathrm{Cr}_{2} \mathrm{O}_{3}$ solubility limit of the $\mathrm{HW} 39$ glass used in the melter test.

One of the test melters at SRS also was affected by the accumulation of spinel phase. Spinel phases may have formed during low-temperature idling of the melter or perhaps because of corrosion of the Monofrax K-3 refractory materials in the melter. Such precipitates are known to have only a very minor effect on the durability of the glass (Bibler 1983, Bickford and Jantzen 1986, Zhu et al. 1986). Because spinels have little effect on properties of the glass, a $\mathrm{Cr}_{2} \mathrm{O}_{3}$ limit is needed mainly to avoid operability problems in the melter and more specifically to minimize the possible precipitation and accumulation of spinel. For the LTM and HTM melters, a $\mathrm{Cr}_{2} \mathrm{O}_{3}$ limit of $0.5 \mathrm{wt} \%$ in glass appears to be reasonable for flat-bottom melters where the accumulation of solids should be minimized. The limit at DWPF is $0.3 \mathrm{wt} \% \mathrm{Cr}_{2} \mathrm{O}_{3}$, that is consistent with the estimated composition envelop for the Phase I HLW glasses. This limit could be increased if reliable methods are developed to remove solids from the melter. Potentially viable methods include agitation or use of bottom-drain systems where the bottom is sloped to aid in removal of sludge.

\subsubsection{Phosphorus Solubility}

Phosphorus, or $\mathrm{P}_{2} \mathrm{O}_{5}$, is relatively insoluble in borosilicate glasses at lower temperature. When such glasses are cooled, phosphorus tends to separate as a molten salt or particulate species (Volf 1984). Even small amounts of $\mathrm{P}_{2} \mathrm{O}_{5}(<0.5$ percent) are apparently immiscible in silicate melts on the molecular scale. It is the coalescence of the immiscible phases into droplets that can create potential problems. Such droplets have been observed to form a "scum" on the surface of the glass melt that reduces throughput capacity of the melter. During the PSCM-19 melter test with WVDP 182 glass, an immiscible surface scum of calcium phosphate was formed (Bunnel 1988). This scum was absorbed through cold cap and coated the residual silica particles added as glass-forming material to the melt. It was found that this scum significantly reduced the melt-rate capacity of the melter. The WVDP 182 glass contained $3.0 \mathrm{wt} \% \mathrm{CaO}, 3.2 \mathrm{wt} \%$ rare earths, and $2.7 \mathrm{wt} \% \mathrm{P}_{2} \mathrm{O}_{5}$. In a parallel test with WVDP 183 glass, a viscous surface scum formed that was found to be enriched in 
rare earth phosphates, once again affecting the melting rate of the melter. The WVDP 183 glass contained $0.7 \mathrm{wt} \% \mathrm{CaO}, 2.0 \mathrm{wt} \%$ rare earths, and $2.6 \mathrm{wt} \% \mathrm{P}_{2} \mathrm{O}_{5}$ (Bunnel 1988).

Scoping studies have indicated that phase separation was caused by the accumulation of sulfate (gall) in WVDP 182 glass, inducing the separation of phosphate and other components from the glass. In crucible studies using oxides and carbonates, the WVDP 182 composition showed phosphate rich segregation after a gall layer formed from more than $1.5 \mathrm{wt} \%$ sulfate in the glass. This gall layer contained sodium, phosphorus, calcium, lanthanum, potassium and sulfur. Based on this evidence, it is assumed that $\mathrm{P}_{2} \mathrm{O}_{5}, \mathrm{CaO}, \mathrm{Li}_{2} \mathrm{O}$, and rare earths accumulate in the gall layer beneath the cold cap. After-the-sulfate volatilizes, a concentrated layer of crystalline calcium rare earth phosphates or other phosphates may be left on the surface of the melt.

This phenomenon is apparently reproducible, judging from the results of recent crucible tests at PNNL where phosphates interacted with rare earths to form an optically transparent secondary phase in quenched and $\mathrm{CCC}$ glasses. Such tests have indicated that the secondary phase consists of $\mathrm{Na}_{3} \mathrm{RE}\left(\mathrm{PO}_{4}\right)_{2}, \mathrm{Li}_{3} \mathrm{PO}_{4}$, or $\mathrm{NdPO}_{4}$, where $\mathrm{RE}$ represents neodymium, cerium, or lanthanum. The sum of the rare earth components varied from 7.3 to $7.8 \mathrm{wt} \%$ and $\mathrm{P}_{2} \mathrm{O}_{5}$ from 3.0 to $9.0 \mathrm{wt} \%$ in these samples. The threshold for $\mathrm{NaRE}\left(\mathrm{PO}_{4}\right)_{2}$ precipitation in the CCC samples appears to be about $3.0 \mathrm{wt} \% \mathrm{P}_{2} \mathrm{O}_{5}$ while the lower limit for $\mathrm{Li}_{3} \mathrm{PO}_{4}$ precipitation is about $3.0 \mathrm{wt} \%$ lithium and $3.0 \mathrm{wt} \% \mathrm{P}_{2} \mathrm{O}_{5}$. However, in one test, $\mathrm{Li}_{3} \mathrm{PO}_{4}$ crystals were observed by $\mathrm{x}$-ray diffraction in a glass that contained $6.84 \mathrm{wt} \% \mathrm{Li}_{2} \mathrm{O}$ and only $1.35 \mathrm{wt} \% \mathrm{P}_{2} \mathrm{O}_{5}$. In CCC glasses, the durability was reduced by the precipitation of $\mathrm{Al}_{3} \mathrm{PO}_{4}$ from glasses with more than $5.5 \mathrm{wt} \% \mathrm{P}_{2} \mathrm{O}_{5}$ and $8.3 \mathrm{wt} \% \mathrm{Al}_{2} \mathrm{O}_{3}$ ( $\mathrm{Li} 1995$ ).

Glasses containing $4.26 \mathrm{wt} \% \mathrm{P}_{2} \mathrm{O}_{5}$ and $0.25 \mathrm{wt} \% \mathrm{CaO}$ were successfully processed in PNNL melters during PSCM-9. Aluminosilicate glasses with $20 \mathrm{wt} \%$ alumina, high-alkaline earth, and low-alkali metal have incorporated as much as $9.4 \mathrm{wt} \% \mathrm{P}_{2} \mathrm{O}_{5}$ without salt separation and with good durability characteristics (Merrill and Janke 1993). High-alumina glasses are apparently capable of absorbing higher levels of phosphate. $\mathrm{Li}_{3} \mathrm{PO}_{4}$ phase separation was detected in SRS's SRL 165 borosilicate glass when more than $4.0 \mathrm{wt} \% \mathrm{PO}_{4}$ (3.0 wt \% $\mathrm{P}_{2} \mathrm{O}_{5}$ ) was added to this composition (Jantzen 1986). Recently, PNNL formulated three borosilicate glasses (ECA 451, 452, and 501) based on an all-tank waste composition for the French low-temperature, induction-heated melter. These glasses contained about $1.0 \mathrm{wt} \% \mathrm{CaO}, 6.6 \mathrm{wt} \%$ rare earths, and up to $2.56 \mathrm{wt} \% \mathrm{P}_{2} \mathrm{O}_{5}$ but did not exhibit any evidence of phase separation or precipitation of phosphate crystals.

In summary, it appears that in some borosilicate glasses, phosphorus tends to form precipitates with calcium, rare earths, and lithium. Molten salt or scum layers may form from low-melting-temperature phosphates and interfere with the operation and melting rate of the melter. A limit of $3.0 \mathrm{wt} \% \mathrm{P}_{2} \mathrm{O}_{5}$ should be acceptable because the Phase I glasses are projected to have less than $1.0 \mathrm{wt} \% \mathrm{P}_{2} \mathrm{O}_{5}$ and $0.85 \mathrm{wt} \% \mathrm{RE}$, and should not be susceptible phosphate induced scum or phase separation in the melter. This limit is aiso consistent with the DWPF phosphate limit of $3.0 \mathrm{wt} \% \mathrm{PO}_{4}\left(2.24 \mathrm{wt} \% \mathrm{P}_{2} \mathrm{O}_{5}\right)$ (Hrma and Piepel 1994), recent test results just described, and limits derived from the WVDP 182 and 183 glasses. 


\subsubsection{Chloride and Fluoride Solubility}

Halides are moderately soluble in silicate glasses at high temperature but separate as droplets or crystals (of $\mathrm{NaCl}, \mathrm{NaF}$ or $\mathrm{CaF}_{2}$ ) at lower temperatures producing optical opacity in the glass due to oversaturation. All halides have high-vapor pressures and may volatilize to a certain extent from the melt. Most commercial glasses contain about $0.6 \mathrm{wt} \%$ fluoride, at most, but the addition of alumina or boric oxide increases the solubility of fluoride to such an extent that about 7 percent of the oxygen can be replaced with fluoride in high-alumina glasses (Volf 1984). Chlorides are only sparingly soluble in glass with a maximum solubility of about $2.3 \mathrm{wt} \%$ as $\mathrm{NaCl}$ at $1,400{ }^{\circ} \mathrm{C}$ in sodium silicate glass and $1.5 \mathrm{wt} \%$ as $\mathrm{KCl}$ in lead silicate glass. In high-silica glasses, such as Pyrex ${ }^{1}$ glass, the solubility limit for chloride is about $0.1 \mathrm{wt} \%$.

The presence of sodium and boric oxides tends to increase the solubility of chloride in borosilicate glass. Pacific Northwest National Laboratory recently developed two glasses for the LLW program, L6-5412 with 5 wt $\% \mathrm{~B}_{2} \mathrm{O}_{3}$ and $\mathrm{L4}-9012$ with 9 wt\% $\mathrm{B}_{2} \mathrm{O}_{3}$. The chlorine solubility was found to be $0.57 \mathrm{wt} \%$ in L6-5412, and $0.49 \mathrm{wt} \%$ in L4-9012 at $1,350{ }^{\circ} \mathrm{C}$, while fluorine solubility limits were 0.92 and $1.18 \mathrm{wt} \%$, respectively. These limits did not vary significantly as a function of temperature over the range from 1,300 to $1,400{ }^{\circ} \mathrm{C}$. The volatility of $\mathrm{NaCl}$ increases from 804 to $1,300^{\circ} \mathrm{C}$, with considerable loss from the melt at $1,300{ }^{\circ} \mathrm{C}$. Fluorides generally volatilize as $\mathrm{SiF}_{2}$ and $\mathrm{BF}_{3}$ because the fluoride losses from borosilicate glasses are greater than those from alkali-lime-silica glasses. Also, chlorides and fluorides have not been linked to the corrosion of refractory materials in the melter. Apparently, refractory corrosion as such can be substantially suppressed with increased alumina content in the glass (Volf 1984).

Scoping tests were conducted to assess the effects of adding up to $5 \mathrm{wt} \%$ fluoride, $5 \mathrm{wt} \% \mathrm{BaO}, 5 \mathrm{wt} \% \mathrm{MnO}_{2}, 2 \mathrm{wt} \% \mathrm{MoO}_{3}$, and $2 \mathrm{wt} \% \mathrm{NiO}$ to $\mathrm{HW} 39$ borosilicate glass (Larson 1989). During the performance of these tests, only 60 to 80 percent of the fluoride was retained in the sample glass. Except for fluoride, none of the other components had any significant effect on viscosity, electrical conductivity, phase behavior, or durability properties of $\mathrm{HW} 39$ glass. At $5 \mathrm{wt} \%$ fluoride, $\mathrm{CaF}_{2}$ phase separation was observed in the glass. This condition is not acceptable because of potential durability problems and the possible impact of $\mathrm{CaF}_{2}$ on melter operations. Glasses with 3.0 and $4.0 \mathrm{wt} \%$ fluoride were optically darker although regions of gross immiscibility were not found. Based on the increased release of sodium, boron, and silicon at $3.0 \mathrm{wt} \%$ fluoride during the MCC-3 durability test, an upper limit of $1.73 \mathrm{wt} \%$ fluoride was established for the HWVP reference glass.

Melter tests have shown that chloride losses can be high (typically about 25 to 50 percent of the feed chloride is lost by evaporation). About $83 \mathrm{wt} \%$ of submicron particles emitted during the PSCM-4 melter test consisted of $\mathrm{NaCl}$. Offgas line deposits formed during melter idling contained $20-90 \mathrm{wt} \% \mathrm{NaCl}$ and as much as $30 \mathrm{wt} \% \mathrm{SO}_{4}$. The PSCM-4 melter runs were performed under a variety of conditions (feed rate, plenum temperature,

\footnotetext{
${ }^{1}$ Pyrex is a trademark of Corning Glass Works.
} 
offgas flowrate, etc.), with feeds of different composition. Offgas deposits containing alkali borates, chlorides, fluorides, chromates, and sulfates were also produced by the Scale Glass Melter (SGM) at Savannah River (Jantzen 1991). Sodium and potassium chlorides, sulfates and borates were found on the interior canister walls, neck and shoulder above the melt line of canisters filled during campaign 10 of the SGM (Jantzen 1992).

During the PSCM-22 and PSCM-23 melter tests, that were conducted under similar conditions, variable amounts of chloride and fluoride were found in the product glass samples (Table 5-9) (Nakaoka 1985, Goles and Anderson 1986, Goles 1989, Goles and Nakaoka 1990).

These values are well below the solubility limits for chloride and fluoride in the literature and limits that were developed from crucible tests of HW39 reference glass. However, these values are useful because they demonstrate that chloride and fluoride are quite volatile, particularly in the presence of cesium and sodium oxides in the melt. The volatility of cesium is directly related to the concentration of chloride in the melt (Goles and Anderson 1986). Pacific Northwest National Laboratory has previously tested melter feeds with $0.3 \mathrm{wt} \%$ chloride (SRS), $0.35 \mathrm{wt} \%$ chloride (WVDP), and $0.08 \mathrm{wt} \%$ chloride (HWVP) (Anantatmula et al. 1991). Although halides can form molten salts that accumulate on the glass surface, only minimal quantities of such salts have ever been observed. There is no generally applicable solubility limit for chloride, although a solubility limit of less than $1.0 \mathrm{wt} \% \mathrm{NaCl}$ is recommended for DWPF (Hrma and Piepel 1994). A limit of $0.5 \mathrm{wt} \% \mathrm{Cl}$ is recommended based on experimental results from the LLW program.

Table 5-11. Chloride and Fluoride Glass Compositions and Percent Retained During Pilot-Scale Ceramic Melter-22 and Pilot-Scale Ceramic Melter-23 Melter Tests.

\begin{tabular}{|l|c|c|c|c|}
\hline Melter test & $\begin{array}{c}\text { Chloride, } \\
\mathrm{p} / \mathrm{M}\end{array}$ & $\begin{array}{c}\text { Chloride, percent } \\
\text { retained }\end{array}$ & Fluoride, $\mathrm{p} / \mathrm{M}$ & $\begin{array}{c}\text { Fluoride, percent } \\
\text { retained }\end{array}$ \\
\hline PSCM-22 & 148 & 19 & 550 & 27 \\
\hline PSCM-23 & 948 & 85 & 1,998 & 90 \\
\hline
\end{tabular}

PSCM = Pilot-scale ceramic melter.

\subsubsection{Sulfate Solubility}

Sulfate is relatively insoluble in borosilicate glass. Molten salt separation, that reduces (or increases) melter throughput capacity, could occur. Poor durability characteristics may be found in glasses with high-sulfate content, particularly if they tend to form a gall or molten sodium sulfate layer on the glass surface. Such layers have been found in some of the test melts with Fernald wastes (Pegg et al. 1994). A molten salt layer could readily 


\section{WHC-SD-WM-TI-768}

\section{Revision 0}

incorporate radionuclides such as cesium, and by doing so, increase the volatility of cesium and possible entrainment losses from the melter. Segregated melts (with liquid sodium sulfate) may extract components that would otherwise remain in the molter glass, such as phosphates, chromates, molybdates and halides. Molten salts also tend to dissolve the refractory and accelerate refractory corrosion processes at the melt line.

Sulfate solubility in glass is sensitive to the oxidation state and basicity of the glass melt. In a study of sulfate in borosilicate glass, the $\mathrm{Fe}^{+2} / \mathrm{Fe}^{+3}$ ratio was systematically varied from 0 to 2.5 for glasses in which 0.5 and $1.0 \mathrm{wt} \%$-sulfate were added to.NCAW at 25 percent WOL (Larson 1989, Bates et al. 1985). The sulfate solubility did not change for the sample with $0.5 \mathrm{wt} \%$ sulfate over the REDOX range of interest $(0.0$ to 0.3$)$. In contrast, all the glass samples with $1.0 \mathrm{wt} \%$ sulfate had a yellow or white surface layer on the glass indicating a limited amount of phase separation at $1.0 \mathrm{wt} \%$ sulfate. The sulfate solubility limit was determined to be $0.9 \mathrm{wt} \%$ for these samples over the REDOX range in the melter ( 0.0 to 0.4 ). Sulfate solubilities decreased about 50 percent as the REDOX ratio increased from 0.5 to 1.0 (reflecting the development of more reducing conditions in the melter).

Pacific Northwest National Laboratory recently developed two glasses for the low level waste (LLW) program, L6-5412 with $4 \mathrm{wt} \% \mathrm{CaO}$, and $\mathrm{L} 4-9012$ with $0 \mathrm{wt} \% \mathrm{CaO}$. The sulfate solubility limit was found to be $0.75 \mathrm{wt} \%$ in L6-5412, and $0.47 \mathrm{wt} \%$ in L4-9012 at 1,350 ${ }^{\circ} \mathrm{C}$, reflecting the favorable impact of calcium on the sulfate solubility limits in borosilicate glass. The HWVP sulfate limit is $0.5 \mathrm{wt} \%$ as $\mathrm{SO}_{3}$ while the DWPF sulfate limit is $0.4 \mathrm{wt} \%$. Both limits are based on the desire to limit sodium sulfate phase separation from the glass.

\subsubsection{Bismuth and Uranium Solubility}

Currently, there are no solubility limits for bismuth oxide $\left(\mathrm{Bi}_{2} \mathrm{O}_{3}\right)$ that can be applied to Phase I glasses. Bismuth oxide is a conditional glass former like $\mathrm{Al}_{2} \mathrm{O}_{3}$. Bismuth has properties in glass most similar to lead due to similarities in electronic configuration and molecular weight (Volf 1984). Bismuth glasses are reported to strongly attack refractory materials. Under reducing conditions, bismuth glasses tend to form a metallic mirror on the surface of the glass. This is not expected to occur in the HLW melter because bismuth is relatively dilute in the HLW. Glass viscosities could be reduced and durability improved with the addition of $\mathrm{Bi}_{2} \mathrm{O}_{3}$. Because of the low bismuth content of Phase I wastes, this component is not expected to effect the behavior of the glass.

Samples of first and second cycle bismuth phosphate waste simulant were vitrified in 1978 to determine the characteristics of this glass (Kupfer 1978). These glasses contained as much as $13 \mathrm{wt} \% \mathrm{Bi}_{2} \mathrm{O}_{3}$ at 40 percent waste oxide loading. Glasses were found to be clear dark green-brown and durable when tested by the soxhlet leach method.

Pacific Northwest Laboratory conducted a single component study of bismuth by varying the concentration of bismuth from 1 to 15 percent in high-temperature 
nonborosilicate glass. The results confirm those of Kupfer (1978). $\mathrm{Bi}_{2} \mathrm{O}_{3}$ decreases viscosity, increases durability, and slightly decreases $T_{L}$ for spinel forming glasses.

Uranium is usually present in the tetravalent and hexavalent state in glass. The hexavalent form is the more stable oxide and is readily soluble in glass while the tetravalent form has only limited solubility (Schreiber and Balazs 1982, Schreiber et al. 1983). The presence of fluoride in uranium-containing glasses is undesirable because uranium fluorides $\left(\mathrm{UF}_{6}\right)$ are quite volatile. Alkali-borate and phosphate glasses may absorb as much as $60 \mathrm{wt} \%$ $\mathrm{UO}_{2}$ under oxidizing conditions. In lithium-barium-silicate glasses, $\mathrm{UO}_{2}$ improves the resistance to devitrification and permits the formulation of glasses that-would otherwise be susceptible to crystallization (Volf 1984).

In a single-component study, no evidence of uranium phase separation was observed over the range of uranium compositions tested ( 0 to $8 \mathrm{wt} \%)$. The normalized uranium release increased from 2.4 to $5.1 \mathrm{~g} / \mathrm{m}^{2}$ as the $\mathrm{UO}_{3}$ concentration increased from 0.15 to $8 \mathrm{wt} \%$ in MCC-1 durability tests. Releases of silicon, boron, lithium, and sodium were 50 percent below EA glass durability standards over this range. Also, the amount of iron in chromite spinel actually decreased with an increase in $\mathrm{UO}_{3}$. In glasses with more than 2 wt $\% \mathrm{UO}_{3}$, the crystalline phase was determined to be $\mathrm{Cr}_{2} \mathrm{O}_{3}$. The viscosity and electrical conductivity properties of borosilicate glass were not affected by $\mathrm{UO}_{2}$ concentrations of up to $8 \mathrm{wt} \%$. Pacific Northwest Laboratory conducted a parametric study to investigate the effects of uranium on the properties of glass. Uranium was completely soluble to a level of $15 \mathrm{wt} \%$ in glass. $\mathrm{UO}_{2}$ slightly decreases glass viscosity and had no measurable effect on glass durability. Uranium does not appear to be a limiting component in HLW glasses at this time.

\subsubsection{Noble Metals Solubility}

Precipitation of silver and noble metals from the glass is one of the most significant feed processability issues for the Phase I feeds. Noble metal oxides and alloys $\left(\mathrm{RuO}_{2}, \mathrm{PdO}\right.$, $\mathrm{Rh}_{2} \mathrm{O}_{3}, \mathrm{Ag}_{2} \mathrm{O}$ ) are only slightly soluble in borosilicate glass. The solubility limit in silicate glass is approximately $0.05 \mathrm{wt} \%$ for rhodium and $0.03 \mathrm{wt} \%$ for palladium (Volf 1984 ). $\mathrm{RuO}_{2}$ has an apparent solubility limit of $0.01 \mathrm{wt} \%$ in borosilicate glasses with less than 25 wt \% $\mathrm{Na}_{2} \mathrm{O}$, but it has a limit of $0.25 \mathrm{wt} \%$ when $\mathrm{Na}_{2} \mathrm{O}$ exceeds $25 \mathrm{wt} \%$ (Mukerji 1972). Some investigators have found that the solubility of noble metals is controlled by the REDOX state of the glass (Schreiber et al. 1991). Significant noble metal-rich deposits have accumulated to form an electrically conductive sludge layer at the bottom of U.S. melters and melters in Germany and Japan (Hutson 1994, Grunewald 1993a, Cooper et al. 1994). This sludge has caused short circuiting of lower electrodes in flat-bottom test melters and failure of at least one bottom-drain system. The conditions under which these deposits have formed have been extensively studied to characterize the nature and morphology of these deposits. Computer simulation studies also have been performed to predict expected melter lifetime based on the accumulation of noble metals when processing high-burnup nuclear wastes such as NCAW DST waste. 
In 1976, Germany began developing a vitrification program for treating radioactive wastes. Most of the initial work was performed on wastes generated from reprocessing fuel at the Eurochemie plant in Mol, Belgium. The low enriched-waste concentrate had a high concentration of noble metals that settled to the floor of the PAMELA melter to form a conductive layer leading to processing difficulties in the melter (Elliott et al. 1994). During the first year of operation, PAMELA produced $47 \mathrm{~m}^{3}$ of vitrified waste. Melter feed rates decreased from 30 to $20 \mathrm{~kg} / \mathrm{h}$ after the first year due to the accumulation of noble metals on the floor of the melter. This layer had an electrical conductivity three times higher than the bulk glass. Because the settled sludge layer was significantly more conductive than the bulk glass, the current field and electrical potential were affected, limiting processing capacity of the melter. Table 5-12 shows the noble metals concentration in the PAMELA feed and retention of noble metals in the melter.

Table 5-12. Noble Metals Feed Composition and Percent Retained in the PAMELA Melter.

\begin{tabular}{|l|c|c|}
\hline \multicolumn{1}{|c|}{ Component } & PAMELA feed, $\mathrm{p} / \mathrm{M}$ & Percent retained in melter \\
\hline Ruthenium & 1,000 to 5,100 & 35.1 \\
\hline Rhodium & 3,000 & 21.2 \\
\hline Palladium & $\mathbf{1 , 4 0 0}$ & -0.2 \\
\hline
\end{tabular}

Assuming 25 percent WOL, the PAMELA melter glass retained 0.12 to $0.17 \mathrm{wt} \%$ noble metals.

A sample of the PAMELA melter bottom glass showed areas of ruthenium concentration 80 times higher than the concentration in the bulk glass. Approximately $215 \mathrm{~m}^{3}$ of highly enriched waste concentrate (with fewer noble metals) was processed through PAMELA during the last campaign. Altogether, four electrode failures were observed. Some believe they may have been caused by electrical shorting of the bottom electrodes while others attribute the failures to electrical asymmetry effects in the melter. In November 1986, the bottom drain failed with the suspected cause being the accumulation of noble metal deposits on the floor of the melter. Finally, in 1988, the PAMELA overflow system failed, leading to the shutdown and replacement of the melter.

Two meiter test campaigns were conducted at SRS for the HWVP project using NCAW simulants with noble metals (Hutson 1994). Table 5-13 shows the approximate noble metals composition of the feed and the percent retained in the melter (Elliott et al. 1994). 
WHC-SD-WM-TI-768

Revision 0

Table 5-13. Noble Metals Feed Composition and Percent Retained in the Savannah River Site Test Melter (IDMS Melter).

\begin{tabular}{|l|c|c|c|c|c|}
\hline \multirow{2}{*}{ Component } & \multicolumn{3}{|c|}{ Feed composition (wt\%) } & \multicolumn{2}{c|}{ Percent retained in melter } \\
\cline { 2 - 6 } & HWVP1 & HWVP2 & NCAW 1991 & HWVP1 & HWVP2 \\
\hline $\mathrm{Ru}_{2} \mathrm{O}_{3}$ & 0.17 & 0.05 & 0.11 & 13.1 & 12.7 \\
\hline $\mathrm{Rh}_{2} \mathrm{O}_{3}$ & 0.05 & 0.01 & 0.03 & 15.1 & 9.2 \\
\hline $\mathrm{PdO}$ & 0.09 & 0.01 & 0.03 & 3.4 & -8.1 \\
\hline
\end{tabular}

DWPF $=$ Defense Waste Processing Facility

HWVP $=$ Hanford Waste Vitrification Plant

IDMS = Integrated DWPF Melter System

NCAW $=$ Neutralized current acid waste.

At an assumed $28 \mathrm{wt} \%$ WOL, HWVP1 and HWVP2 glasses retained 0.077 and $0.017 \mathrm{wt} \%$ noble metals, respectively.

A small research scale (1/100-scale) melter test was performed in FY 1991 to assess the impact of noble metals on melter operation (Cooper et al. 1994). The nominal feed consisted of NCAW simulant with the appropriate concentration of noble metals. During one of the latter segments, the feed concentration of noble metals was doubled so the impact of feed concentration on settling behavior could be evaluated. Toward the end of the melter campaign, the resistance between electrodes decreased. Upon destructive examination of the melter, a layer of noble metals was found on the bottom of the melter and approximately one-third of one electrode was lost due to corrosion or localized overheating. The metal layer at the bottom also removed approximately $1.3 \mathrm{~cm}$ of the bottom refractory. This also has been observed in commercial melters where bottom refractories have been attacked by downward drilling of molten metals. Mass balance calculations indicate that approximately 5 percent of the noble metals present in the feed precipitated to the floor during segments of the test with nominal noble metals concentration $\left(0.332 \mathrm{wt} \%\right.$, including $\left.\mathrm{Ag}_{2} \mathrm{O}\right)$, and 46 percent precipitated during segments with higher noble metals concentration $(0.465 \mathrm{wt} \%)$ in the melter feed. The agglomeration and precipitation of noble metals occurred over an average residence time of only 5 hours in the melter. Glass samples taken from the bottom of the research-scale melter contained clusters of $\mathrm{RuO}_{2}$ needles and metallic particles of $\mathrm{Ru} / \mathrm{Rh}$ surrounded by layers of $\mathrm{Pd} / \mathrm{Ag} / \mathrm{Te}$ alloy and $\mathrm{RuO}_{2}$ (Cooper et al. 1994).

An engineering-scale (1/10-scale) melter test was conducted at Kfk in FY 1992 to evaluate the behavior of noble metals during prolonged melter operation at the projected plant operating conditions (Grunewald 1993b). The melter feed consisted of NCAW simulant with the normal noble metals content. During the 49 days of testing with NCAW, about 35 percent of the ruthenium, palladium, and rhodium fed to the melter settled to the melter floor. Samples taken from the bottom of the melter at the end of the run had high concentrations of noble metals, 20 to 45 times those of the nominal glass. Near the end of the run, the electrical resistance between the lower set of electrodes decreased by 10 to 


\section{Revision 0}

15 percent, consistent with the presence of a noble metals layer on the floor of the melter. In a related study, it was observed that the solubility of palladium increases with oxygen fugacity or concentration in the glass, but at constant oxygen fugacity the solubility of palladium increased only slightly with temperature.

During the most recent series of large-scale melter tests in Japan, a total of $40.9 \mathrm{~m}^{3}$ of simulated HLW was processed. Noble metal composition in the melter feed, retention rates, and average glass compositions are presented in Table 5-14.

Table 5-14. Noble Metals Feed Composition, Percent Retained, and Average Glass Composition in Large-Scale Japanese Melter Tests.

\begin{tabular}{|l|c|c|c|}
\hline \multicolumn{1}{|c|}{ Component } & $\begin{array}{c}\text { Melter feed } \\
(\mathrm{wt} \%)\end{array}$ & Percent retained & $\begin{array}{c}\text { Percent glass } \\
\text { composition }\end{array}$ \\
\hline $\mathrm{RuO}_{2}$ & 2.25 & 0.08 & 0.87 \\
\hline $\mathrm{PdO}$ & 1.06 & 0.09 & 0.51 \\
\hline
\end{tabular}

In contrast to earlier melter campaigns, these results were obtained from a slopedbottom melter with a bottom-drain valve. In general, the Japanese have observed that the accumulation rate of noble metals can be sharply reduced by increasing the slope of the melter floor and using a bottom-drain system. This observation is important because it suggests that the shape and design of the melter have a significant effect on the accumulation rate and acceptable solubility limit for noble metals.

The preliminary limit for HWVP noble metals is less than $0.25 \mathrm{wt} \%$ $\mathrm{Ru}_{2} \mathrm{O}_{3}+\mathrm{PdO}+\mathrm{Rh}_{2} \mathrm{O}_{3}$ in glass (Kalia 1992a). This limit is well above solubility limits derived from other studies, that indicate flat-bottom melters may be susceptible to premature electrical failure at noble metals concentrations as low as $0.1 \mathrm{wt} \%$ in glass.

\subsubsection{Titanium Solubility}

Titanium oxides can adversely affect the homogeneity of glass by inducing precipitation of spinel and lithium and sodium aluminum silicates. Titanium oxide also reduces glass viscosity and enhances the solubility of actinides. As the $\mathrm{TiO}_{2}$ concentration is raised from 0 to $10 \mathrm{wt} \%$, the solubility of uranium in borosilicate glass increases from 15 to $30 \mathrm{wt} \%$ while the solubility of plutonium increases from 2 to $4 \mathrm{wt} \%$ (Plodinec 1979). However, the main concern is the impact of $\mathrm{TiO}_{2}$ on devitrification of the glass. The primary crystalline phases formed after the addition of $\mathrm{TiO}_{2}$ are alkali aluminosilicates. 


\section{Revision 0}

Titanium oxide is commonly used as a nucleating agent in lithium and magnesium aluminosilicate glasses for the production of glass ceramics. Titanium oxide is effective for inducing the precipitation of alkali aluminosilicates because of its poor solubility in alumina rich glasses. About 3 to $4 \mathrm{wt} \% \mathrm{TiO}_{2}$ is normally used to nucleate glass ceramics in $\mathrm{Li}_{2} \mathrm{O}-\mathrm{Al}_{2} \mathrm{O}_{3}-\mathrm{SiO}_{2}$ glasses, while 8 to $10 \mathrm{wt} \% \mathrm{TiO}_{2}$ is required for $\mathrm{MgO}_{-} \mathrm{Al}_{2} \mathrm{O}_{3}-\mathrm{SiO}_{2}$ glasses. Formation of these phases could seriously affect the operation of the melter (Plodinec 1979, Plodinec and Wilds 1978). Rutile $\left(\mathrm{TiO}_{2}\right)$ crystallized in the PAMELA melter outlet channel and pour spout when glasses with $1.55 \mathrm{wt} \% \mathrm{TiO}_{2}, 20.68 \mathrm{wt} \% \mathrm{Al}_{2} \mathrm{O}_{3}, 21.7 \mathrm{wt} \% \mathrm{~B}_{2} \mathrm{O}_{3}$, and $3.1 \mathrm{wt} \% \mathrm{Li}_{2} \mathrm{O}$ were melted. The bottom drain plugged several times and rutile crystals formed in the glass that remained in the outlet channel for-some time (Langowski 1994).

When aluminosilicates dissolve, the viscosity of glass in the vicinity of the crystals increases, retarding or slowing dissolution of the crystals. If this material is formed in the throat of a joule-heated melter, it could seriously affect the glass-pouring operation and overall melter performance. Even if this material passes through the melter, it is likely to be rich in radiocesium and highly leachable. In addition to other factors, the depletion of aluminum in the glass matrix due to the precipitation of lithium aluminum silicate may reduce the durability of certain glasses. An almost linear relationship exists between the extent of devitrification and the $\mathrm{TiO}_{2}$ content in glass (Plodinec 1979). Because the rate and extent of devitrification depend directly on $\mathrm{TiO}_{2}$ concentration, DWPF glasses are limited to a maximum concentration of $1.0 \mathrm{wt} \% \mathrm{TiO}_{2}$. The DWPF glasses are currently projected to have 4 to $7 \mathrm{wt} \% \mathrm{Al}_{2} \mathrm{O}_{3}, 3$ to $5 \mathrm{wt} \% \mathrm{Li}_{2} \mathrm{O}$, and 8 to $12 \mathrm{wt} \% \mathrm{Na}_{2} \mathrm{O}$ and $\mathrm{B}_{2} \mathrm{O}_{3}$ (WSRC 1992).

In contrast to recent experience with borosilicate glasses, no evidence of crystallinity was found in alumina-silicate glasses with 1.0 to $8.0 \mathrm{wt} \% \mathrm{TiO}_{2}$ (HTB651-7 through -12), after these glasses were quenched from $1,350{ }^{\circ} \mathrm{C}(\mathrm{Li} \mathrm{1995)}$. The HTB651 series of glasses contains 16 to $17 \mathrm{wt} \% \mathrm{Na}_{2} \mathrm{O}$ and 8.4 to $12.0 \mathrm{wt} \% \mathrm{Al}_{2} \mathrm{O}_{3}$, but no $\mathrm{Li}_{2} \mathrm{O}$. Based the phase equilibrium diagram for the $\mathrm{Na}_{2} \mathrm{O}-\mathrm{Al}_{2} \mathrm{O}_{3}-\mathrm{SiO}_{2}$ system, nepheline would have precipitated from such glasses with 19 to $29 \mathrm{wt} \% \mathrm{Na}_{2} \mathrm{O}, 29$ to $30 \mathrm{wt} \% \mathrm{Al}_{2} \mathrm{O}_{3}$, and 45 to $55 \mathrm{wt} \% \mathrm{SiO}_{2}$ at $1,350{ }^{\circ} \mathrm{C}$. The acceptable concentration limits for $\mathrm{TiO}_{2}$ are inevitably linked to the concentration of other components in the glass, especially $\mathrm{Al}_{2} \mathrm{O}_{3}, \mathrm{Li}_{2} \mathrm{O}, \mathrm{B}_{2} \mathrm{O}_{3}$ and $\mathrm{Na}_{2} \mathrm{O}$, as these components affect the precipitation of alkali aluminosilicates. Based on presently available information, a $\mathrm{TiO}_{2}$ limit of $3 \mathrm{wt} \% \mathrm{TiO}_{2}$ in low $(2$ to $3 \mathrm{wt} \%) \mathrm{Li}_{2} \mathrm{O}$ borosilicate glasses, and $5 \mathrm{wt} \% \mathrm{TiO}_{2}$ in low ( 2 to $3 \mathrm{wt} \%$ ) $\mathrm{Li}_{2} \mathrm{O}$ aluminosilicate glasses is believed to be acceptable, pending the completion of more definitive studies to determine the precise glass composition limits for $\mathrm{TiO}_{2}$.

\subsubsection{Minor Component Solubility Limits}

Table 5-15 summarizes the minor component solubility limits recommended in this study and compares these limits to those developed for HWVP and DWPF. 
Table 5-15. Minor Component Glass Solubility Limits for High-Level Waste.

\begin{tabular}{|l|c|c|c|}
\hline \multicolumn{1}{|c|}{ Component } & Current study (wt\%) & HWVP (wt\%) & DWPF (wt\%) \\
\hline $\mathrm{Cr}_{2} \mathrm{O}_{3}$ & $<0.5^{\mathrm{a}}$ & $<0.5$ & $<0.3$ \\
\hline $\mathrm{P}_{2} \mathrm{O}_{5}$ & $<3.0^{\mathrm{b}}$ & $<1.0$ & $<3.0$ (as $\mathrm{PO}_{4}$ ) \\
\hline $\mathrm{SO}_{3}$ & $<0.5$ & $<0.5$ & $<0.4$ (as $\mathrm{SO}_{4}$ ) \\
\hline $\mathrm{Cl}$ & $\sim 0.5$ & no limit & $<1.0$ (as NaCl) \\
\hline $\mathrm{F}$ & $<1.7$ & $<1.7$ & $<1.0$ (as NaF) \\
\hline $\mathrm{Bi}_{2} \mathrm{O}_{3}$ & $<13.0$ & no limit & no limit \\
\hline $\mathrm{UO}_{3}$ & $<15.0$ & no limit & no limit \\
\hline $\mathrm{Ru}_{2} \mathrm{O}_{3}+\mathrm{PdO}^{2} \mathrm{Rh}_{2} \mathrm{O}_{3}+\mathrm{Ag}_{2} \mathrm{O}$ & $<0.1-0.2^{\mathrm{c}}$ & $<0.25$ & no limit \\
\hline $\mathrm{TiO}_{2}$ & $<3.0$ (Borosilicate), & no limit & $<1.0$ \\
\hline $\mathrm{Cu}$ & $<5.0$ (aluminosilicate) & & $<0.3$ \\
\hline
\end{tabular}

DWPF $=$ Defense Waste Processing Facility

HWVP $=$ Hanford Waste Vitrification Plant

${ }^{a} \mathrm{The}_{2} \mathrm{Cr}_{2} \mathrm{O}_{3}$ solubility limit may increase to $1.0 \mathrm{wt} \%$ for low-iron borosilicate and nonborosilicate glasses depending on the results of glass and melter feature development testing.

bimit for $\mathrm{P}_{2} \mathrm{O}_{5}$ based on commensurate limits of $<3.0 \mathrm{wt} \% \mathrm{Li}_{2} \mathrm{O},<1.0 \mathrm{wt} \% \mathrm{CaO}$, and $<1.5 \mathrm{wt} \%$ rare earths (cerium, lanthanum, and neodymium).

'Flat-bottom melter with no bottom drain.

\subsection{COMPARISON OF SIMULANTS TO RADIOACTIVE PHASE I WASTES}

Most studies have relied on simulants to represent the properties of radioactive waste. Due to the relative costs involved, cold simulants have normally been used for the feed chemistry, HLW glass formulation and melter development programs at the Hanford Site, SRS, WVDP, and abroad. Laboratory-scale tests with radioactive waste are therefore needed to establish a credible link between simulant based studies and the behavior of actual tank wastes during feed preparation and vitrification of such wastes. This comparison not only helps to validate simulant tests, but also provides a basis for validating the glass property models used to formulate HLW glasses of acceptable composition.

Three core samples of radioactive waste were recovered from Phase I Tanks 241-AZ-101 and 241-AZ-102 in 1989. Small portions were used in laboratory-scale feed preparation and vitrification tests to produce representative samples of radioactive glass. The next section will briefly describe the nature of this testing program and will compare the properties of the radioactive samples to simulants and glass model predictions for this waste (Morrey 1995). 


\section{WHC-SD-WM-TI-768}

Revision 0

The solids from each core were taken through a prescribed pretreatment process for Phase I wastes, using a water wash/settle/decant sequence, with ferric-nitrate flocculent, and two water washes ( 3 volumes deionized water to each volume of sludge). These samples were then analyzed to determine the composition of the washed solids. Afterwards, the washed solids were adjusted to an average concentration of $125 \mathrm{~g}$ waste oxide/L and treated with formic acid to adjust feed rheology and to chemically reduce REDOX-sensitive species (Fe, $\mathrm{Mn}$, etc.) in the waste. Frit was then added to simulate the last step in the feed preparation process. The formatted slurry and frit/slurry samples were thoroughly characterized as to their chemical, radiochemical, physical and rheological properties. Frit/slurry mixtures were dried and melted at $1,150{ }^{\circ} \mathrm{C}$ in crucibles.and resulting glasses were analyzed to determine their chemical and radiochemical composition, durability (PCT and MCC-1 tests), crystallinity, REDOX state and density.

\subsubsection{Slurry Properties}

The main components in the waste are $\mathrm{Fe}, \mathrm{Al}$, and $\mathrm{Na}$, present in the form of $\mathrm{OH}^{-}$, $\mathrm{CO}_{3}^{-2}, \mathrm{NO}_{3}^{-}$, and $\mathrm{NO}_{2}^{-}$.

Slurry simulants were prepared using PNNL's procedure (WTC-006-36). In this procedure, major components such as $\mathrm{Al}, \mathrm{Fe}, \mathrm{Mn}, \mathrm{Ni}$, and $\mathrm{Zr}$ are precipitated with $\mathrm{NaOH}$ from nitrate solutions and washed to remove sodium and nitrate. Insoluble minor components ( $\mathrm{Ag}, \mathrm{Cd}, \mathrm{Ce}, \mathrm{Cr}, \mathrm{La}$, etc.) are co-precipitated, washed and blended with major components. Soluble and slightly soluble components (B, Ba, $\mathrm{Ca}, \mathrm{Cs}, \mathrm{Cu}, \mathrm{Na}$, etc.) are added as oxides, hydroxides, fluorides and sulfates, while $\mathrm{Na}$ is added in multiple forms to match carbonate and anion fractions in the waste. Simulant compositions were designed to match the composition of the radioactive samples.

During the formatting process, $\mathrm{CO}_{3}^{-2}, \mathrm{NO}_{3}^{-}$, and $\mathrm{NO}_{2}{ }^{-}$are converted into $\mathrm{CO}_{2}, \mathrm{NO}_{\mathrm{x}}$, and other nitrogen compounds $\left(\mathrm{N}_{2}, \mathrm{~N}_{2} \mathrm{O}, \mathrm{NH}_{3}\right)$, while the concentration of these anions in the sample is reduced. Slurry chemistry and offgas generation reactions were found to be similar for core samples and simulants, with any differences being explained by testing conditions and slurry chemical composition effects. The only radionuclides affected by the washing step were ${ }^{137} \mathrm{Cs}$ and ${ }^{125} \mathrm{Sb}$, while ${ }^{129} \mathrm{I}$ was the only radionuclide that may have been lost during the formatting step. Settling behavior of the simulants did not match the behavior of the core samples in that the core samples settled much more quickly and achieved a much higher solids density than the simulants. Previous studies have shown that when the core samples are allowed to dry, the settling and rheological properties of the sample can be irreversibly changed. However, the particle size distribution of the core samples did not change during the feed preparation process. Most particles were less than 5 microns in diameter, with a significant fraction less than 1 micron.

The rheology properties of the radioactive waste were also different from those of the simulant. Formic acid treated wastes had a lower yield stress and lower apparent viscosity than the formatted simulant. The rheology characteristics of the waste can best be described 
as pseudoplastic yield behavior with slight shear-thinning and some hysteresis. The rheology properties of the wastes and simulants are compared in Table 5-16. At Savannah River, yield stresses were reduced and settling rates increased for radioactive (potassium tetraphenylborate) slurries, compared to nonradioactive simulants, because of radiation induced de-agglomeration of the sludge (Morrey 1995). These effects could also be responsible for the differences between the Phase I wastes and simulants.

Table 5-16. Comparison of Radioactive Sample and Simulant Rheology Properties.

\begin{tabular}{|l|c|c|c|c|c|c|}
\hline & \multicolumn{3}{|c|}{ Radioactive Samples } & \multicolumn{3}{c|}{ Simulants } \\
\cline { 2 - 7 } & $\begin{array}{c}\text { Yield Stress, } \\
\mathrm{Pa}\end{array}$ & $\begin{array}{c}\text { Apparent } \\
\text { Viscosity @ 50 } \\
\mathrm{s}^{-1}, \mathrm{cP}\end{array}$ & $\begin{array}{c}\text { Total } \\
\text { oxides, } \\
\text { Wo/L }\end{array}$ & $\begin{array}{c}\text { Yield } \\
\text { Stress, Pa }\end{array}$ & $\begin{array}{c}\text { Apparent } \\
\text { Viscosity @ } \\
\mathrm{s}^{-1}, \mathrm{cP}\end{array}$ & $\begin{array}{c}\text { Total oxides, } \\
\mathrm{g} \mathrm{Wo} / \mathrm{L}\end{array}$ \\
\hline Formatted slurry & 0.85 to 0.23 & 3.8 to 7.2 & 101 to 147 & 1.2 & 32 & 147 to 161 \\
\hline $\begin{array}{l}\text { Frit/formatted } \\
\text { slurry }\end{array}$ & 1.4 to 10.3 & 38 to 260 & 479 to 600 & 2.2 to 12.4 & 58 to 365 & 438 to 573 \\
\hline
\end{tabular}

\subsubsection{Glass Properties}

Based on standard $\mathrm{KOH} / \mathrm{Na}_{2} \mathrm{O}_{2}$ fusion and ICP/AES analysis procedures, the measured analytes were generally found to be within 10 percent of the target values predicted from the washed solids composition, frit compositions and estimated waste loadings for the glasses. The REDOX ratio $\left(\mathrm{Fe}^{2} / \mathrm{Fe}^{3}\right.$ ) varied from 0.026 to 0.085 for the radioactive glasses, compared to 0.005 for the simulant. The radioactive glasses were analyzed by $\mathrm{X}$-ray diffraction to determine the composition of the crystalline phases. Since the radioactive glasses were formulated to a liquidus temperature of less than $900{ }^{\circ} \mathrm{C}$, very little if any crystallinity was found in the quenched samples (less than $1 \mathrm{vol} \%$ ). In one sample from Tank 241-AZ-101, ruthenium oxide was tentatively identified as a solid phase of minor significance. The density of the radioactive glasses ranged from $2.56 \mathrm{~g} / \mathrm{cc}$ for Tank 241-AZ-101 core 1, to $2.67 \mathrm{~g} / \mathrm{cc}$ for Tank $241-\mathrm{AZ}-101$ core 2 , and $2.54 \mathrm{~g} / \mathrm{cc}$ for Tank 241-AZ-102 at room temperature, densities that are consistent with the simulant glasses for these wastes.

Each of the radioactive and simulant glasses proved to be a highly durable waste form, at least 15 times more durable than the Savannah River EA glass as measured by PCT (Table 5-9). The durability results and model predictions are summarized in Tables 5-17, 5-18, and 5-19. Seven-day B releases for the radioactive glasses ranged from 0.13 to $0.22 \mathrm{~g} / \mathrm{m}^{2}$, compared to simulant boron releases of 0.2 to $0.34 \mathrm{~g} / \mathrm{m}^{2}$. The CVS second-order mixture model \#3 for durability, described in Section 5.6 and Table 5-10, tends to overpredict releases in high-durability glasses and under-predict releases in low-durability glasses. 


\section{Revision 0}

Table 5-17. Durability Results for 241-AZ-101, Core 1 Glass.

(Mean Normalized Release, $\mathrm{g} / \mathrm{m}^{2}$ )

\begin{tabular}{|c|c|c|c|}
\hline Component & Radioactive glass & Simulant glass & CVS model $\left(2^{\text {nd }}\right.$ order, $\left.\# 3\right)$ \\
\hline $\mathrm{B}$ & 0.130 & 0.200 & 0.4801 \\
\hline $\mathrm{Li}$ & 0.226 & 0.245 & 0.5008 \\
\hline $\mathrm{Na}$ & 0.144 & 0.199 & 0.3589 \\
\hline $\mathrm{Si}$ & 0.077 & 0.129 & \\
\hline
\end{tabular}

Table 5-18. Durability Results for 241-AZ-101, Core 2 Glass. (Mean Normalized Release, $\mathrm{g} / \mathrm{m}^{2}$ )

\begin{tabular}{|c|c|c|c|}
\hline Component & Radioactive glass & Simulant glass & CVS model $\left(2^{\text {nd }}\right.$ order, $\left.\sharp 3\right)$ \\
\hline $\mathrm{B}$ & 0.223 & 0.338 & 0.4364 \\
\hline $\mathrm{Li}$ & 0.293 & 0.369 & 0.4212 \\
\hline $\mathrm{Na}$ & 0.105 & 0.248 & 0.2948 \\
\hline $\mathrm{Si}$ & 0.141 & 0.184 & \\
\hline
\end{tabular}

Table 5-19. Durability Results for 241-AZ-102, Core 1 Glass. (Mean Normalized Release, $\mathrm{g} / \mathrm{m}^{2}$ )

\begin{tabular}{|c|c|c|c|}
\hline Component & Radioactive glass & Simulant glass & CVS model $\left(2^{\text {nd }}\right.$ order, \#3) \\
\hline $\mathrm{B}$ & 0.211 & 0.271 & 0.6775 \\
\hline $\mathrm{Li}$ & 0.301 & 0.351 & 0.6338 \\
\hline $\mathrm{Na}$ & 0.049 & 0.130 & 0.3971 \\
\hline $\mathrm{Si}$ & 0.158 & 0.163 & \\
\hline
\end{tabular}




\section{Revision 0}

Radiation has a significant effect on glass corrosion in aqueous leaching tests.

Radiation effects can be mitigated by using Ar in the leach containers to minimize radiolytic nitric acid production. The dominant corrosion mechanism appears to be network hydrolysis that occurs under higher $\mathrm{pH}$ conditions. Seven day PCT and 28 day MCC- 1 radionuclide releases were measured. As with previous studies, normalized releases of Am ranged from 0.1 to 6 percent of the B releases. Also consistent with previous studies, Tc, $\mathrm{U}, \mathrm{Np}$, and $\mathrm{Cs}$ were generally more soluble than Am (>10 percent of the B-normalized release).

However, Pu releases were similar to those of $\mathrm{B}$, while $\mathrm{Sr}$ was relatively soluble in $\mathrm{MCC}-1$ and insoluble in the PCT tests. The durability results are based on triplicate samples and standard reference glasses, with tests performed in-cell and out-of-cell in fused-silica-lined stainless steel and teflon containers, respectively. 
WHC-SD-WM-TI-768

Revision 0

This page intentionally left blank. 
WHC-SD-WM-TI-768

Revision 0

\subsection{PROCESSABILITY ASSESSMENT FOR PHASE I FEEDS}

In this section, optimum WOL and glass composition estimates are developed for representative Phase I feeds as a function of composition for the LTM. These estimates are be used as a basis for predicting the volume of glass produced from the Phase I wastes. These data are needed for development of the Phase I High-Level Waste Pretreatment and Feed Staging Plan (Manuel et al. 1996) and to assess the need for caustic washing and for specific blending strategies to minimize the potential volume of Phase I HLW glasses. These glass composition estimates, provided by PNNL, -are based on current glass property data correlations (models) for borosilicate glass, especially the first and second order models that were developed during the composition variability study (CVS) at the Hanford Site (Hrma 1994). Because of the importance of glass volume, sensitivity studies were performed to evaluate effects of feed composition and more aggressive caustic washing processes for these wastes.

The composition limits of the CVS study (or composition range of glasses in the CVS) have sometimes been used to estimate the composition limits for HLW glasses, without assurance that these glasses also meet property constraints for the LTM. A much more reliable basis for evaluating glass composition is to use empirical glass property data and property models for borosilicate glass. These models can be used to estimate the most important properties of the glass based on the combined effect of all of the major components in the glass. Generally, good empirical models for viscosity, electrical conductivity and PCT releases are available, but comparable models for liquidus temperature are still being developed. Liquidus temperature is likely to be the property that limits waste loading for Phase I privatization feeds. It was, therefore, necessary to obtain additional liquidus temperature data for the Phase I glasses.

The balance of process issues also will be addressed in this section, including an assessment of volatile components that may affect the performance of the melter offgas system. Other operability issues include corrosion of offgas and feed preparation system components, nitrogen oxide emissions and criticality control.

\subsection{WASTE COMPOSITIONS FOR GLASS FORMULATION DEVELOPMENT}

The wastes compositions of interest include water washed (WW) and caustic washed (CW) sludges from Tanks 241-AZ-101, 241-AZ-102, 241-AY-102, and 241-C-106. For glass formulation purposes, several blends were also considered, including a blend of Tanks 241-AZ-101 and 241-AZ-102 (AZ blend), and a nominal blend (consisting of 80 percent of Tank 241-AZ-101, 80 percent of Tank 241-AZ-102, 32 percent of Tank 241-C-106, and 15 percent of Tank 241-AY-102 wastes). The nominal blend is assumed to have 32 percent of the waste in Tank 241-C-106, while the Phase I RFP nominal blend contains 37 percent of the Tank 241-C-106 waste. This difference as to the assumed retrieval fraction for Tank 241-C-106 has an insignificant effect on composition of the glass. The Phase I waste 
compositions were derived from the Tank Characterization Reports for Tanks 241-AZ-101, 241-AZ-102, and 241-AY-102, except for the sludge and aluminum inventories in Tank 241-AZ-101. Composition estimates for Tank 241-C-106 are based on the Data Transmittal Package for Tank 241-C-106 (Weiss 1986). Because of possible uncertainties in the Tank 241-C-106 aluminum inventory, two separate estimates are provided for this waste (241-C-106A from Weiss and 241-C-106B based on Hara) (Weiss 1986, Hara 1990). Water and caustic washed sludge compositions were developed from core sample washing studies, analytical results for Tank 241-C-106 waste and from caustic washing results for Tank 241-C-103 waste (as the best available surrogate for Tank 241-C-106 waste) (Peterson 1989, Gray 1993a, Gray 1993b, Weiss 1986, and Rapko-1995).

Feed compositions reported in Manuel et al. (1996) are slightly different from those used in this study for glass formulation purposes. These differences do not materially affect the feed processability evaluation and are bounded by sensitivity studies in this report.

To bracket the expected range of glass compositions, PNNL has experimentally developed optimum glass compositions for the water and caustic washed nominal blend, and water washed 241-C-106A, 241-C-106B, and AZ blend. Water washing removes water soluble species and caustic washing, performed in addition to water washing, decreases the aluminum, chromium and phosphorus in the waste. The waste compositions used for glass formulation are listed in Table 6-1. 
Table 6-1. Waste and Blend Compositions in Mass Fractions on Nonvolatile Oxide Basis. Only components of $\geq 0.1 \mathrm{wt} \%$ are included in this table

\begin{tabular}{|c|c|c|c|c|c|}
\hline Oxide & Nominal-W & Nominal-C & C106A-W & C106B-W & AZ-W \\
\hline $\mathrm{Ag}_{2} \mathrm{O}$ & 0.0015 & 0.0016 & 0.0012 & 0.0037 & 0.0013 \\
\hline $\mathrm{Al}_{2} \mathrm{O}_{3}$ & 0.1684 & 0.0960 & 0.1618 & 0.3555 & 0.1739 \\
\hline $\mathrm{As}_{2} \mathrm{O}_{3}$ & 0.0009 & 0.0009 & 0.0000 & 0.0008 & 0.0017 \\
\hline $\mathrm{B}_{2} \mathrm{O}_{3}$ & 0.0014 & 0.0015 & 0.0001 & 0.0014 & 0.0022 \\
\hline $\mathrm{BaO}$ & 0.0062 & 0.0068 & 0.0114 & 0.0006 & 0.0015 \\
\hline $\mathrm{BeO}$ & 0.0014 & 0.0015 & 0.0028 & 0.0000 & 0.0001 \\
\hline $\mathrm{CaO}$ & 0.0212 & 0.0232 & 0.0348 & 0.0043 & 0.0081 \\
\hline $\mathrm{CdO}$ & 0.0142 & 0.0156 & 0.0009 & 0.0000 & 0.0268 \\
\hline $\mathrm{CeO}_{2}$ & 0.0014 & 0.0015 & 0.0000 & 0.0000 & 0.0025 \\
\hline $\mathrm{Cr}_{2} \mathrm{O}_{3}$ & 0.0045 & 0.0044 & 0.0030 & 0.0042 & 0.0057 \\
\hline $\mathrm{CoO}$ & 0.0019 & 0.0021 & 0.0000 & 0.0000 & 0.0037 \\
\hline $\mathrm{CuO}$ & 0.0007 & 0.0008 & 0.0003 & 0.0006 & 0.0010 \\
\hline F- & 0.0012 & 0.0013 & 0.0000 & 0.0000 & 0.0019 \\
\hline $\mathrm{Fe}_{2} \mathrm{O}_{3}$ & 0.2662 & 0.2918 & 0.1559 & 0.1929 & 0.3656 \\
\hline $\mathrm{K}_{2} \mathrm{O}$ & 0.0060 & 0.0066 & 0.0033 & 0.0000 & 0.0084 \\
\hline $\mathrm{La}_{2} \mathrm{O}_{3}$ & 0.0057 & 0.0062 & 0.0000 & 0.0000 & 0.0107 \\
\hline $\mathrm{MgO}$ & 0.0126 & 0.0138 & 0.0228 & 0.0011 & 0.0029 \\
\hline $\mathrm{MnO}$ & 0.0069 & 0.0076 & 0.0050 & 0.0095 & 0.0082 \\
\hline $\mathrm{Na}_{2} \mathrm{O}$ & 0.2190 & 0.2400 & 0.2515 & 0.2916 & 0.1915 \\
\hline $\mathrm{Nd}_{2} \mathrm{O}_{3}$ & 0.0038 & 0.0041 & 0.0000 & 0.0000 & 0.0071 \\
\hline $\mathrm{NiO}$ & 0.0110 & 0.0121 & 0.0025 & 0.0000 & 0.0188 \\
\hline $\mathrm{P}_{2} \mathrm{O}_{\mathrm{s}}$ & 0.0097 & 0.0036 & 0.0119 & 0.0232 & 0.0072 \\
\hline $\mathrm{PbO}$ & 0.0035 & 0.0039 & 0.0053 & 0.0043 & 0.0020 \\
\hline $\mathrm{Rh}_{2} \mathrm{O}_{3}$ & 0.0006 & 0.0006 & 0.0000 & 0.0000 & 0.0011 \\
\hline $\mathrm{RuO}_{2}$ & 0.0007 & 0.0008 & 0.0000 & 0.0000 & 0.0013 \\
\hline $\mathrm{Sb}_{2} \mathrm{O}_{3}$ & 0.0015 & 0.0016 & 0.0000 & 0.0057 & 0.0028 \\
\hline $\mathrm{SeO}_{2}$ & 0.0019 & 0.0021 & 0.0000 & 0.0030 & 0.0037 \\
\hline $\mathrm{SiO}_{2}$ & 0.1626 & 0.1782 & 0.3182 & 0.0911 & 0.0232 \\
\hline $\mathrm{SrO}$ & 0.0006 & 0.0007 & 0.0003 & 0.0002 & 0.0010 \\
\hline $\mathrm{SO}_{3}$ & 0.0040 & 0.0044 & 0.0000 & 0.0000 & 0.0077 \\
\hline $\mathrm{TeO}_{2}$ & 0.0014 & 0.0015 & 0.0000 & 0.0000 & 0.0027 \\
\hline $\mathrm{ThO}_{2}$ & 0.0006 & 0.0007 & 0.0000 & 0.0000 & 0.0012 \\
\hline $\mathrm{TiO}_{2}$ & 0.0006 & 0.0007 & 0.0000 & 0.0009 & 0.0011 \\
\hline $\mathrm{Tl}_{2} \mathrm{O}$ & 0.0032 & 0.0035 & 0.0000 & 0.0020 & 0.0062 \\
\hline $\mathrm{U}_{3} \mathrm{O}_{8}$ & 0.0135 & 0.0148 & 0.0010 & 0.0018 & 0.0242 \\
\hline $\mathrm{ZrO}_{2}$ & 0.0384 & 0.0421 & 0.0058 & 0.0013 & 0.0690 \\
\hline $\mathrm{M}_{\mathrm{W}}(\mathrm{Mg})$ & 396 & 358 & 486 & 310 & 282 \\
\hline
\end{tabular}


WHC-SD-WM-TI-768

Revision 0

\subsection{GLASS FORMULATION}

This section summarizes work to develop glass formulations and glass property estimates for Phase I glasses. Phase I glasses developed by PNNL were formulated for a low-temperature, joule-heated melter (LTM) operating at $1,150{ }^{\circ} \mathrm{C}$. Glass properties of most importance are viscosity, electrical conductivity, liquidus temperature, and leach resistance or durability properties of the glass. The Phase I glasses are formulated for a viscosity and electrical conductivity of $5.0 \mathrm{~Pa}-\mathrm{s}$ and 0.18 to $0.50 \mathrm{~S} / \mathrm{cm}$ at $1,150^{\circ} \mathrm{C}$, respectively, a liquidus temperature of less than $1,050^{\circ} \mathrm{C}$ (at least $100{ }^{\circ} \mathrm{C}$ below the nominal operating temperature of the melter), and boron and sodium releases, as determined by the PCT test, of less than $2.0 \mathrm{~g} / \mathrm{m}^{2}$. Liquidus temperature is especially important because this is the highest temperature where the melt is in equilibrium with the primary crystalline phase (at lower temperatures, possible sludge forming conditions could develop in the melter). Liquidus temperature appears to be the limiting constraint for most Phase I glasses. The wastes in Table 6-1 contain a significant inventory of refractory oxides $\left(\mathrm{Al}_{2} \mathrm{O}_{3}, \mathrm{Fe}_{2} \mathrm{O}_{3}\right.$ and $\mathrm{ZrO}_{2}$ ) that promote crystallization. As previous studies have shown, the optimum glasses developed from these wastes are likely to be limited by liquidus temperature criteria. High $\mathrm{Al}_{2} \mathrm{O}_{3}$ concentrations can also cause the crystallization of nepheline $\left(\mathrm{NaAlSiO}_{4}\right)$ in the canister, which adversely affects the durability of the glass (Kim et al. 1995). Borosilicate glasses typically contain at least $5 \mathrm{wt} \% \mathrm{~B}_{2} \mathrm{O}_{3}$, as a defined borosilicate waste form. The optimum glass is one that allows the maximum waste oxide loading in the glass subject to the following conditions:

$\mathrm{SiO}_{2}$ : Glasses may become structurally unstable if the $\mathrm{SiO}_{2}$ concentration is reduced to less than approximately $37 \mathrm{wt} \%$. This limit is recommended for glass formulation purposes because little information is available on component effects at lower $\mathrm{SiO}_{2}$ concentration. The optimum $\mathrm{SiO}_{2}$ concentration also depends on the composition of other components in the glass. The CVS range for $\mathrm{SiO}_{2}$ is 42 to $57 \mathrm{wt} \%$ (Table 5-3).

$\mathrm{B}_{2} \mathrm{O}_{3}$ : Low-temperature glasses should have more than $5 \mathrm{wt} \% \mathrm{~B}_{2} \mathrm{O}_{3}$ to meet the minimum standards for borosilicate glass, as defined in the WASRD glossary. The CVS range for $\mathrm{B}_{2} \mathrm{O}_{3}$ is 5 to $20 \mathrm{wt} \%$ (Table 5-3).

$\mathrm{Al}_{2} \mathrm{O}_{3}$ : The CVS range for $\mathrm{Al}_{2} \mathrm{O}_{3}$ is presently 0 to $17 \mathrm{wt} \%$ (Table 5-3). High $\mathrm{Al}_{2} \mathrm{O}_{3}$ concentrations increase the potential for nepheline precipitation in the canister (above 14 to $17 \mathrm{wt} \% \mathrm{Al}_{2} \mathrm{O}_{3}$ ) and lithium aluminum silicate precipitation in the melter.

$\mathrm{Fe}_{2} \mathrm{O}_{3}$ : The CVS range for $\mathrm{Fe}_{2} \mathrm{O}_{3}$ is 0.5 to $15 \mathrm{wt} \%$ (Table 5-3). High $\mathrm{Fe}_{2} \mathrm{O}_{3}$ in combination with $\mathrm{Cr}_{2} \mathrm{O}_{3}, \mathrm{MnO}$, and $\mathrm{NiO}$ increases the risk of spinel precipitation in the melter, as measured by the liquidus temperature of the glass. 


\section{Revision 0}

$\mathrm{ZrO}_{2}: \quad$ For $\mathrm{ZrO}_{2}$, the CVS range is currently 0 to $13 \mathrm{wt} \%$, although zirconium containing phases often precipitate from borosilicate glasses with more than 7 to $10 \mathrm{wt} \% \mathrm{ZrO}_{2}$.

$\mathrm{Na}_{2} \mathrm{O}$ : The CVS range for $\mathrm{Na}_{2} \mathrm{O}$ is 5 to $20 \mathrm{wt} \%$ (Table 5-3). High $\mathrm{Na}_{2} \mathrm{O}$ tends to reduce glass durability and increase the likelihood of nepheline precipitation in the canister.

$\mathrm{Li}_{2} \mathrm{O}$ : The upper limit for $\mathrm{Li}_{2} \mathrm{O}$ should be 3 to $4 \mathrm{wt} \% \mathrm{Li}_{2} \mathrm{O}$ to minimize possible precipitation of eucriptite $\left(\mathrm{LiAlSi}{ }_{2} \mathrm{O}_{6}\right)$ from high-lithium and -alumina containing glasses. Eucriptite crystals have been known to precipitate from borosilicate glass with 16.4 to $24.6 \mathrm{wt} \% \mathrm{Al}_{2} \mathrm{O}_{3}$ and 5.9 to $6.5 \mathrm{wt} \% \mathrm{Li}_{2} \mathrm{O}$. $\mathrm{Na}_{2} \mathrm{O}$ is generally preferred for viscosity control because of $\mathrm{Li}_{2} \mathrm{O}$ induced precipitation of lithium phosphates and lithium aluminum silicates (except where nepheline is more likely to precipitate than eucriptite).

$\mathrm{CaO}: \quad \mathrm{CaO}$ may be used if it is necessary to reduce the viscosity but not the durability of glass. This situation typically occurs when the alkali components have reached their maximum acceptable limit. The CVS range for $\mathrm{CaO}$ is 0 to $10 \mathrm{wt} \%$ (Table 5-3).

MgO: $\quad \mathrm{MgO}$ should not be used as a glass or frit additive component because $\mathrm{MgO}$ typically increases the liquidus temperature of spinel and zirconiumcontaining phases, and decreases durability.

Melting For each composition, glass-melting temperatures should match Temperature: the operating temperature of the melter $\left(1,150^{\circ} \mathrm{C}\right.$ for the LTM).

Glass The glass viscosity should be $5 \mathrm{~Pa}$-s but could vary from 4 to $6 \mathrm{~Pa}$-s at the Viscosity: operating temperature of the melter $\left(1,150^{\circ} \mathrm{C}\right)$.

Elec. The electrical conductivity of the glass should be between 0.18 and Conductivity: $\quad 0.50 \mathrm{~S} / \mathrm{cm}$ at $1,150{ }^{\circ} \mathrm{C}$.

Liquidus As stated in the previous paragraph, the liquidus temperature limit Temperature: for the $\mathrm{LTM}$ is $1,050^{\circ} \mathrm{C}\left(100^{\circ} \mathrm{C}\right.$ less than the nominal operating temperature of the melter $-1,150^{\circ} \mathrm{C}$ ) to minimize spinel and zirconia precipitation in the glass and the development of sludge forming conditions in the melter. 
Durability: Durability estimates are based on normalized PCT boron and sodium releases. The composition is controlled such that boron and sodium releases are limited to less than $2 \mathrm{~g} / \mathrm{m}^{2}$ over the 7-day PCT interval. This is a conservative limit designed to compensate for uncertainty in durability model prediction for glass compositions that may be outside the normal range the model. Glass compositions should not be adjusted if boron and sodium PCT releases are less than $2 \mathrm{~g} / \mathrm{m}^{2}$. In addition, giass composition should be adjusted to preclude nepheline precipitation in the canister, as determined by optical and scanning electron microscopy (SEM) and PCT boron and sodium releases from the $\mathrm{CCC}$ samples.

Nepheline Region: As discussed in Section 5.6, FY 1996 work indicates the nepheline region in the phase diagram is generally defined by the following limits:
1. $0.43<\mathrm{SiO}_{2}<0.62$
2. $\mathrm{Al}_{2} \mathrm{O}_{3}<1.67 * \mathrm{Na}_{2} \mathrm{O}$
3. $\mathrm{Al}_{2} \mathrm{O}_{3}<0.28$
4. $\mathrm{Al}_{2} \mathrm{O}_{3}+0.57 * \mathrm{SiO}_{2}>0.43$

where $\mathrm{Na}_{2} \mathrm{O}, \mathrm{Al}_{2} \mathrm{O}_{3}$ and $\mathrm{SiO}_{2}$ are mass fractions of each component normalized to the sum of the three components. The nepheline can be avoided by defining a minimum limit for $\mathrm{SiO}_{2}$ such that glasses with a normalized $\mathrm{SiO}_{2}$ content $\geq 0.62$ (based on the sum of the $\mathrm{SiO}_{2}+\mathrm{Na}_{2} \mathrm{O}+\mathrm{Al}_{2} \mathrm{O}_{3}$ ) should not form nepheline in the canister.

Glass Models: The CVS first and second-order mixture models should be used to predict the viscosity, electrical conductivity and durability properties of the glass. Several models are available for liquidus temperature prediction, but these models, and especially the component coefficients in these models, need to be improved by statistical analysis of the CVS database, the DWPF (spinel) database and recent laboratory data that define the component concentration limits for spinel and zirconium containing phases in borosilicate glasses.

PNNL used these criteria to develop two separate glass compositions for each of the identified wastes, one with $25 \mathrm{wt} \%$ and the other with more than $25 \mathrm{wt} \%$ adjusted feed oxide (W'). The adjusted feed oxide (W') is defined as the weight of total non-volatile feed oxides excluding sodium and silica on an oxide basis divided by the weight of the product glass. The glass compositions and predicted properties are shown in Tables 6-2, 6-3, and 6-4 for the water and caustic washed nominal blend, water washed $\mathrm{AZ}$ blend and water washed 241-C-106A and 241-C-106B waste compositions, respectively. 


\section{Revision 0}

Table 6-2. Waste Loadings, Glass Compositions, Glass Property Predictions, and Additive Composition: Nominal Blend Waste.

\begin{tabular}{|c|c|c|c|c|c|}
\hline Waste & NOM-1 & NOM-2 & NOM-3 & NOMC-1 & NOMC-2 \\
\hline \multicolumn{6}{|c|}{ Waste loading } \\
\hline $\mathrm{W}^{\prime}$ & 0.35 & 0.25 & 0.30 & 0.30 & 0.25 \\
\hline W & 0.56 & 0.40 & 0.48 & 0.51 & 0.43 \\
\hline \multicolumn{6}{|l|}{ Glass } \\
\hline $\mathrm{SiO}_{2}$ & 0.4003 & 0.5011 & 0.4113 & $0: 4535$ & 0.5221 \\
\hline $\mathrm{B}_{2} \mathrm{O}_{3}$ & 0.0500 & 0.0982 & 0.1093 & 0.0500 & 0.0588 \\
\hline $\mathrm{Na}_{2} \mathrm{O}$ & 0.1921 & 0.0913 & 0.1733 & 0.1883 & 0.1177 \\
\hline $\mathrm{Li}_{2} \mathrm{O}$ & 0.0100 & 0.0600 & 0.0100 & 0.0100 & 0.0521 \\
\hline $\mathrm{CaO}$ & 0.0119 & 0.0086 & 0.0102 & 0.0119 & 0.0100 \\
\hline $\mathrm{MgO}$ & 0.0071 & 0.0051 & 0.0060 & 0.0071 & 0.0059 \\
\hline $\mathrm{Fe}_{2} \mathrm{O}_{3}$ & 0.1500 & 0.1076 & 0.1278 & 0.1500 & 0.1254 \\
\hline $\mathrm{Al}_{2} \mathrm{O}_{3}$ & 0.0949 & 0.0681 & 0.0808 & 0.0493 & 0.0412 \\
\hline $\mathrm{ZrO}_{2}$ & 0.0216 & 0.0155 & 0.0184 & 0.0216 & 0.0181 \\
\hline $\mathrm{P}_{2} \mathrm{O}_{5}$ & 0.0055 & 0.0039 & 0.0046 & 0.0019 & 0.0015 \\
\hline Others & 0.0566 & 0.0406 & 0.0482 & 0.0563 & 0.0471 \\
\hline \multicolumn{6}{|c|}{ Glass Properties (Predicted) } \\
\hline TM $\left({ }^{\circ} \mathrm{C}\right)$ & 1,150 & 1,150 & 1,150 & 1,150 & 1,150 \\
\hline $\mathrm{T}_{\mathrm{L}}\left({ }^{\circ} \mathrm{C}\right)$ & -- & 990 & 1,053 & 1,042 & 998 \\
\hline$r_{B}\left(g / m^{2}\right)$ & 0.74 & 0.62 & 1.07 & 1.72 & 1.23 \\
\hline $\mathrm{r}_{\mathrm{Na}}\left(\mathrm{g} / \mathrm{m}^{2}\right)$ & 0.37 & 0.33 & 0.47 & 0.77 & 0.81 \\
\hline \multicolumn{6}{|l|}{ Additives } \\
\hline $\mathrm{SiO}_{2}$ & 0.7071 & 0.7308 & 0.6409 & 0.7447 & 0.7812 \\
\hline $\mathrm{B}_{2} \mathrm{O}_{3}$ & 0.1127 & 0.1639 & 0.2089 & 0.1013 & 0.1019 \\
\hline $\mathrm{Na}_{2} \mathrm{O}$ & 0.1574 & 0.0047 & 0.1311 & 0.1336 & 0.0256 \\
\hline $\mathrm{Li}_{2} \mathrm{O}$ & 0.0228 & 0.1006 & 0.0191 & 0.0204 & 0.0913 \\
\hline
\end{tabular}

Notes: Waste loadings and component concentrations are in mass fractions.

Symbols: $W$ waste loading, $W^{\prime}$ adjusted feed oxide loading, $T_{M}$ melting temperature (temperature at which glass viscosity is $5 \mathrm{~Pa}-\mathrm{s}$ ), $\mathrm{T}_{\mathrm{L}}$ liquidus temperature predicted using the empirical second-order model, $\mathrm{r}_{\mathrm{B}}$ and $\mathrm{r}_{\mathrm{Na}}$ 7-day PCT normalized release of boron and sodium. 


\section{Revision 0}

Table 6-3. Waste Loadings, Glass Compositions, Glass Property Predictions, and Additive Composition: AZ Blend Waste.

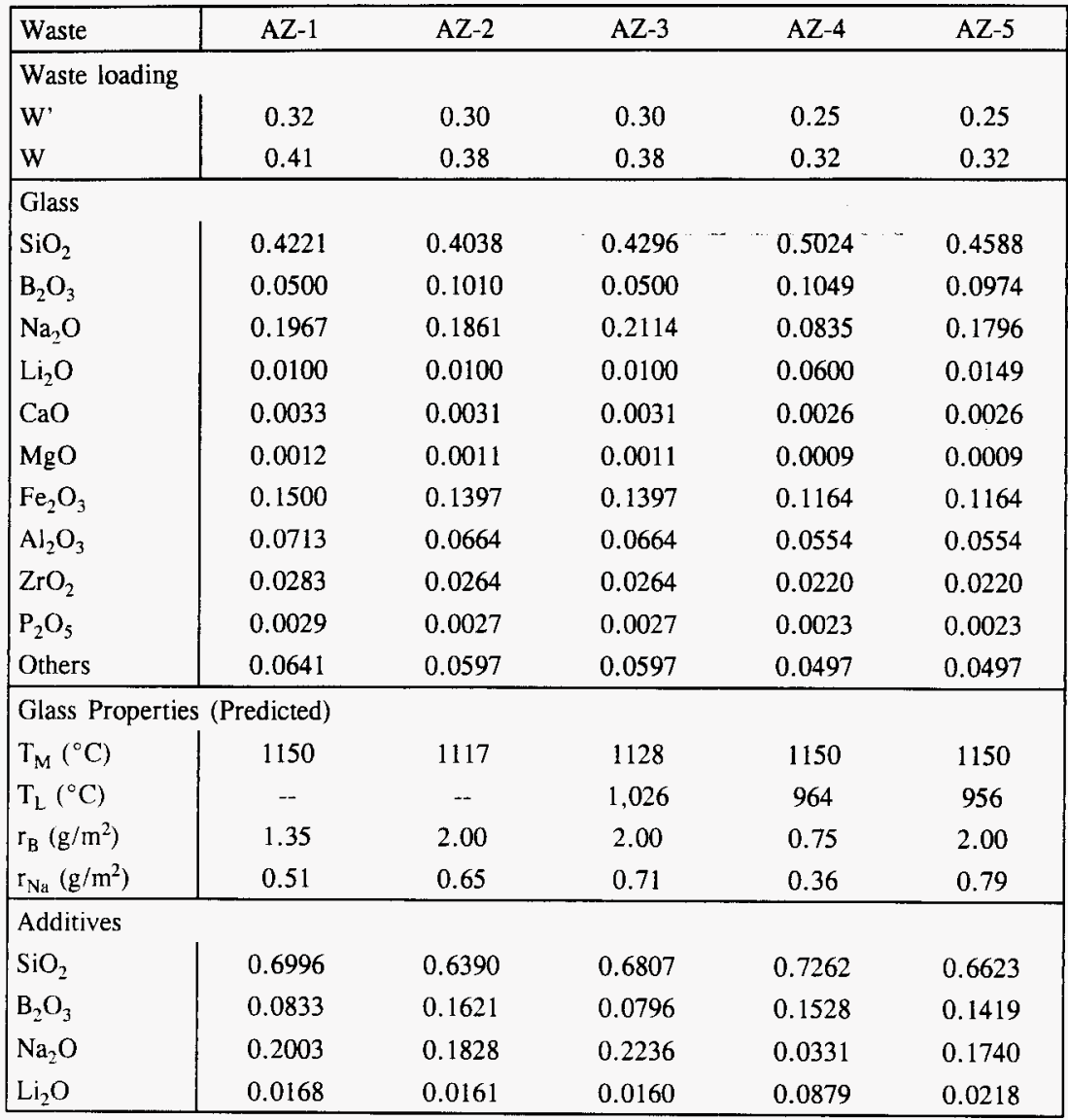

Notes: Waste loadings and component concentrations are in mass fractions.

Symbols: $W$ waste loading, $W^{\prime}$ adjusted feed oxide loading, $T_{M}$ melting temperature (temperature at which glass viscosity is $5 \mathrm{~Pa}-\mathrm{s}$ ), $\mathrm{T}_{\mathrm{L}}$ liquidus temperature predicted using the empirical second-order model, $\mathrm{r}_{\mathrm{B}}$ and $\mathrm{r}_{\mathrm{Na}}$ 7-day PCT normalized release of boron and sodium. 


\section{Revision 0}

Table 6-4. Waste Loadings, Glass Compositions, Glass Property Predictions, and Additive Composition: 241-C-106 Tank Waste.

\begin{tabular}{|c|c|c|c|c|c|c|}
\hline Waste & C106A-1 & C106A-2 & C106A-3 & C106A-4 & C106B-1 & C106B-2 \\
\hline \multicolumn{7}{|c|}{ Waste loading } \\
\hline $\mathrm{W}^{\prime}$ & 0.37 & 0.34 & 0.32 & 0.25 & 0.28 & 0.25 \\
\hline w & 0.85 & 0.80 & 0.75 & 0.58 & 0.45 & 0.41 \\
\hline \multicolumn{7}{|l|}{ Glass } \\
\hline $\mathrm{SiO}_{2}$ & 0.3700 & 0.3849 & 0.4135 & 0.4806 & 0.3700 & 0.4501 \\
\hline $\mathrm{B}_{2} \mathrm{O}_{3}$ & 0.0501 & 0.0500 & 0.0500 & 0.0831 & 0.1853 & 0.1094 \\
\hline $\mathrm{Na}_{2} \mathrm{O}$ & 0.2136 & 0.2209 & 0.1886 & 0.1461 & 0.1316 & 0.1311 \\
\hline $\mathrm{Li}_{2} \mathrm{O}$ & 0.0007 & 0.0000 & 0.0252 & 0.0402 & 0.0351 & 0.0599 \\
\hline $\mathrm{CaO}$ & 0.0296 & 0.0278 & 0.0261 & 0.0200 & 0.0020 & 0.0018 \\
\hline $\mathrm{MgO}$ & 0.0194 & 0.0182 & 0.0171 & 0.0132 & 0.0005 & 0.0005 \\
\hline $\mathrm{Fe}_{2} \mathrm{O}_{3}$ & 0.1325 & 0.1248 & 0.1170 & 0.0906 & 0.0871 & 0.0781 \\
\hline $\mathrm{Al}_{2} \mathrm{O}_{3}$ & 0.1375 & 0.1295 & 0.1214 & 0.0940 & 0.1604 & 0.1440 \\
\hline $\mathrm{ZrO}_{2}$ & 0.0049 & 0.0046 & 0.0044 & 0.0034 & 0.0006 & 0.0005 \\
\hline $\mathrm{P}_{2} \mathrm{O}_{5}$ & 0.0101 & 0.0095 & 0.0089 & 0.0069 & 0.0105 & 0.0094 \\
\hline Others & 0.0316 & 0.0298 & 0.0279 & 0.0216 & 0.0170 & 0.0152 \\
\hline \multicolumn{7}{|c|}{ Glass Properties (Predicted) } \\
\hline $\mathrm{T}_{\mathrm{M}}\left({ }^{\circ} \mathrm{C}\right)$ & 1,150 & 1,150 & 1,120 & 1,150 & 1,150 & 1,150 \\
\hline $\mathrm{T}_{\mathrm{L}}\left({ }^{\circ} \mathrm{C}\right)$ & -- & 1,011 & 979 & 927 & 999 & 877 \\
\hline$r_{B}\left(g / m^{2}\right)$ & 0.36 & 0.44 & 0.49 & 0.56 & 1.73 & 0.58 \\
\hline $\mathrm{r}_{\mathrm{Na}}\left(\mathrm{g} / \mathrm{m}^{2}\right)$ & 0.30 & 0.34 & 0.47 & 0.47 & 0.69 & 0.27 \\
\hline \multicolumn{7}{|l|}{ Additives } \\
\hline $\mathrm{SiO}_{2}$ & 0.6627 & 0.6517 & 0.6995 & 0.7057 & 0.5994 & 0.6945 \\
\hline $\mathrm{B}_{2} \mathrm{O}_{3}$ & 0.3327 & 0.2496 & 0.1997 & 0.1982 & 0.3366 & 0.1828 \\
\hline $\mathrm{Na}_{2} \mathrm{O}$ & 0.0000 & 0.0987 & 0.0000 & 0.0000 & 0.0000 & 0.0220 \\
\hline $\mathrm{Li}_{2} \mathrm{O}$ & 0.0047 & 0.0000 & 0.1008 & 0.0960 & 0.0640 & 0.1007 \\
\hline
\end{tabular}

Notes: Waste loadings and component concentrations are in mass fractions.

Symbols: $W$ waste loading, $W$ ' adjusted feed oxide loading, $T_{M}$ melting temperature (temperature at which glass viscosity is $5 \mathrm{~Pa}-\mathrm{s}$ ), $\mathrm{T}_{\mathrm{L}}$ liquidus temperature predicted using the second-order, $\mathrm{r}_{\mathrm{B}}$ and $\mathrm{r}_{\mathrm{Na}}$ 7-day PCT normalized release of boron and sodium. 
Eleven glasses were formulated to experimentally verify the predicted properties for each glass, with two glasses representing the bounding composition limits for each waste $\left(\mathrm{W}^{\prime}=25 \mathrm{wt} \%\right.$ and $\mathrm{W}^{\prime}=\max \mathrm{wt} \%$ ) plus one additional glass for $241-\mathrm{C}-106 \mathrm{~A}$ waste (Vienna et al. 1996). The properties of these glasses are listed in Tables 6-5, 6-6, and 6-7. The following sections summarize formulation and experimental results for each of the identified feed composition scenarios.

\subsubsection{Glass Formulation Development for the Water Washed Nominal Blend}

The water washed nominal blend is projected to have high concentrations of $\mathrm{Al}_{2} \mathrm{O}_{3}$ (16.8 wt \%), $\mathrm{Fe}_{2} \mathrm{O}_{3}(26.6 \mathrm{wt} \%)$ and $\mathrm{Na}_{2} \mathrm{O}(21.9 \mathrm{wt} \%)$, Table 6-1. Current models indicate the maximum loading of this waste should be $56 \mathrm{wt} \%$ in glass, based on the $\mathrm{T}_{\mathrm{L}}$ limit. Three glasses were initially formulated to represent the likely composition range for this waste. The first glass, referred to as nom- 1 with $56 \mathrm{wt} \%$ waste, produced a few spinel crystals at $1,150{ }^{\circ} \mathrm{C}$ and an unacceptable inventory of crystals after 24 hours at $1,050^{\circ} \mathrm{C}\left(\mathrm{T}_{\mathrm{L}}\right.$ limit for the LTM). The nom-2 and nom-3 glasses, with 40 and $48 \mathrm{wt} \%$ waste, respectively, were found to be totally free of crystals after 24 hours at $1,050^{\circ} \mathrm{C}$, satisfying the $T_{L}$ constraints for this waste. These two glasses were further characterized and the results are summarized in Table 6-5.

The $\mathrm{T}_{\mathrm{m}}$ of the nom-2 glass was measured at $1,151{ }^{\circ} \mathrm{C}$, only $1{ }^{\circ} \mathrm{C}$ above the predicted value. Normalized boron and sodium releases from the quenched glass $\left(0.30\right.$ and $\left.0.24 \mathrm{~g} / \mathrm{m}^{2}\right)$ were found to be in reasonable agreement with the predicted values for this glass $(0.62$ and $\left.0.33 \mathrm{~g} / \mathrm{m}^{2}\right)$. After canister centerline cooling, the nom- 2 glass produced $3 \mathrm{vol} \%$ spinel. The normalized releases of boron and sodium from the CCC glass $\left(0.37\right.$ and $\left.0.47 \mathrm{~g} / \mathrm{m}^{2}\right)$ were only slightly higher than the baseline values for the quenched glass, indicating only a very minor decrease in durability from slow cooling. For this glass, the $T_{L}$ was determined to be $1,009{ }^{\circ} \mathrm{C}\left(19{ }^{\circ} \mathrm{C}\right.$ above the predicted value based on the second order $\mathrm{T}_{\mathbf{L}}$ model) with spinel as the primary crystalline phase. Bright green, yellow, and light brown streaks were observed in the quenched samples of glass. These colors were caused by $10 \mathrm{~nm}$ spherical particles, identified by transmission electron microscopy (TEM) as silver-copper-iron alloy. These colloidal particles were sensitive to thermal conditions of the glass, disappearing from the glass after annealing at $1,050{ }^{\circ} \mathrm{C}$ and during canister centerline cooling.

The $\mathrm{T}_{\mathrm{m}}$ of nom- 3 glass was found to be $7{ }^{\circ} \mathrm{C}$ above the anticipated value of $1,150{ }^{\circ} \mathrm{C}$. Normalized boron and sodium releases from the quenched glass $\left(0.35\right.$ and $\left.0.26 \mathrm{~g} / \mathrm{m}^{2}\right)$ were lower than predicted values for this glass $\left(1.07\right.$ and $\left.0.47 \mathrm{~g} / \mathrm{m}^{2}\right)$. This sample produced $1.8 \mathrm{vol} \%$ spinel and $0.2 \mathrm{vol} \%$ silver after CCC. Normalized releases of boron and sodium from the CCC glass $\left(0.44\right.$ and $\left.0.49 \mathrm{~g} / \mathrm{m}^{2}\right)$ were slightly higher than from the quenched sample, showing a slight decrease in durability with slow cooling. The $T_{L}$ was determined to be $1,047^{\circ} \mathrm{C}$, slightly below the predicted value of $1,053{ }^{\circ} \mathrm{C}$. Spinel was identified as the primary crystalline phase, with colored streaks similar to those found in the nom-2 glass, that disappeared after annealing for 2 hours at $1,150{ }^{\circ} \mathrm{C}$ or for 24 hours at $1,050{ }^{\circ} \mathrm{C}$. Both glasses (nom-2 and nom-3) were deemed to have acceptable properties for the LTM, with the nom-1 glass having an unacceptably high $T_{L}$ (that could lead to sludge forming conditions in 


\section{Revision 0}

the LTM). Based on these results, the maximum waste oxide loading (W) for this composition lies between 48 and $56 \mathrm{wt} \%$ in glass.

Table 6-5. Waste Loading, Measured Glass Properties and Crystalline Phases in the Water Washed and Caustic Washed Nominal Blend Glasses.

\begin{tabular}{|l|c|c|c|c|}
\hline \multicolumn{1}{|c|}{ Waste } & Nom-2 & Nom-3 & Nomc-1 & Nomc-2 \\
\hline $\mathrm{W}, \mathrm{wt} \%$ & 40 & 48 & 51 & 43 \\
\hline $\mathrm{W}, \mathrm{wt}^{\prime} \%$ & 25 & 30 & 30 & 25 \\
\hline $\mathrm{T}_{\mathrm{m}},{ }^{\circ} \mathrm{C}$ & 1,151 & 1,157 & 1,195 & 1,167 \\
\hline $\mathrm{n}_{1150}, \mathrm{~Pa}-\mathrm{s}$ & 5.0 & 5.4 & 7.6 & 5.7 \\
\hline $\mathrm{T}_{\mathrm{L}},{ }^{\circ} \mathrm{C}$ & 1,009 & 1,047 & 1,005 & 998 \\
\hline $\mathrm{P}$ & $\mathrm{S}$ & $\mathrm{S}$ & $\mathrm{S}$ & $\mathrm{S}$ \\
\hline $\mathrm{V}_{\mathrm{C}, \mathrm{S}}, \mathrm{vol} \%$ & 3.0 & 1.8 & 2.0 & 1.8 \\
\hline $\mathrm{V}_{\mathrm{C} . \mathrm{Ag}}, \mathrm{vol} \%$ & & 0.2 & & 0.2 \\
\hline $\mathrm{r}_{\mathrm{B}, \mathrm{Q}}, \mathrm{g} / \mathrm{m}^{2}$ & 0.3 & 0.35 & 0.5 & 0.41 \\
\hline $\mathrm{r}_{\mathrm{Na}, \mathrm{Q}}, \mathrm{g} / \mathrm{m}^{2}$ & 0.24 & 0.26 & 0.64 & 0.42 \\
\hline $\mathrm{r}_{\mathrm{B} . \mathrm{C}, \mathrm{g} / \mathrm{m}^{2}}$ & 0.37 & 0.44 & 0.58 & 0.54 \\
\hline $\mathrm{r}_{\mathrm{Na}, \mathrm{C}}, \mathrm{g} / \mathrm{m}^{2}$ & 0.47 & 0.49 & 0.67 & 0.56 \\
\hline
\end{tabular}

Notes: $\mathrm{W}$ waste loading, $\mathrm{W}^{\prime}$ adjusted waste loading, $\mathrm{T}_{\mathrm{m}}$ melting temperature, $\eta_{1150}$ viscosity at $1,150{ }^{\circ} \mathrm{C}, \mathrm{T}_{\mathrm{L}}$ liquidus temperature, $\mathrm{P}$ primary crystalline phase, $\mathrm{S}$ spinel $(\mathrm{Ni}, \mathrm{Fe})(\mathrm{Fe}, \mathrm{Cr})_{2} \mathrm{O}_{4}, \mathrm{Ag}$ silver particles detected by $\mathrm{x}$-ray diffraction (XRD), $\mathrm{V}_{\mathrm{c}}$ volume percent crystals, $Q$ quenched glass, $C$ canister centerline cooled glass, $r_{b}$ and $r_{\mathrm{Na}} 7$-day PCT normalized release of boron and sodium. 
WHC-SD-WM-TI-768

Revision 0

Table 6-6. Waste Loading, Measured Property Values, and Crystalline Phases in Water Washed AZ Blend Glasses.

\begin{tabular}{|c|c|c|}
\hline Waste & AZ-3 & AZ-5 \\
\hline W, wt\% & 38 & 32 \\
\hline W', wt \% & 30 & 25 \\
\hline $\mathrm{T}_{\mathrm{m}},{ }^{\circ} \mathrm{C}$ & 1,179 & 1,150 \\
\hline $\mathrm{n}_{1150}, \mathrm{~Pa}-\mathrm{s}$ & 6.8 & 5.1 \\
\hline $\mathrm{T}_{\mathrm{L}}$ & 1,048 & 953 \\
\hline $\mathrm{P}$ & $\mathrm{S}$ & $\mathrm{S}$ \\
\hline $\mathrm{V}_{\mathrm{C}, \mathrm{S}}, \mathrm{vol} \%$ & 2.0 & $<1$ \\
\hline $\mathrm{r}_{\mathrm{B}, \mathrm{Q}}, \mathrm{g} / \mathrm{m}^{2}$ & 0.46 & 0.41 \\
\hline $\mathrm{r}_{\mathrm{Na}, \mathrm{Q}}, \mathrm{g} / \mathrm{m}^{2}$ & 0.78 & 0.43 \\
\hline $\mathrm{r}_{\mathrm{B}, \mathrm{C}}, \mathrm{g} / \mathrm{m}^{2}$ & 0.66 & 0.43 \\
\hline $\mathrm{r}_{\mathrm{Na}, \mathrm{C}}, \mathrm{g} / \mathrm{m}^{2}$ & 0.71 & 0.54 \\
\hline
\end{tabular}

Notes: $\mathrm{W}$ waste loading, $\mathrm{W}^{\prime}$ adjusted waste loading, $\mathrm{T}_{\mathrm{m}}$ melting temperature, $\eta_{1150}$ viscosity at $1,150^{\circ} \mathrm{C}, \mathrm{T}_{\mathrm{L}}$ liquidus temperature, $\mathrm{P}$ primary crystalline phase, $\mathrm{S}$ spinel $(\mathrm{Ni}, \mathrm{Fe})(\mathrm{Fe}, \mathrm{Cr})_{2} \mathrm{O}_{4}, \mathrm{Ag}$ silver particles detected by $\mathrm{x}$-ray diffraction (XRD), $\mathrm{V}_{\mathrm{c}}$ volume percent crystals, $Q$ quenched glass, $C$ canister centerline cooled glass, $r_{b}$ and $r_{\mathrm{Na}}$ 7-day PCT normalized release of boron and sodium. 


\section{Revision 0}

Table 6-7. Waste Loading, Measured Glass Properties and Crystalline Phases in the Water Washed 241-C-106A and 241-C-106B Glasses.

\begin{tabular}{|c|c|c|c|c|c|}
\hline Waste & C106A-2 & C106A-3 & C106A-4 & C106B-1 & C106B-2 \\
\hline $\mathrm{W}, \mathrm{wt} \%$ & 80 & 75 & 58 & 45 & 41 \\
\hline $\mathrm{W}, \mathrm{wt} \%$ & 34 & 32 & 25 & 28 & 25 \\
\hline $\mathrm{T}_{\mathrm{m}},{ }^{\circ} \mathrm{C}$ & 1,190 & 1,177 & 1,160 & 1,131 & 1,153 \\
\hline $\mathrm{n}_{1150}, \mathrm{~Pa}-\mathrm{s}$ & 7.5 & 6.5 & 5.6 & 4.3 & 5.1 \\
\hline $\mathrm{T}_{\mathrm{L}},{ }^{\circ} \mathrm{C}$ & 1,004 & 1,029 & 885 & 986 & 894 \\
\hline $\mathrm{P}$ & $\mathrm{S}$ & $\mathrm{S}$ & $\mathrm{S}$ & $\mathrm{H}, \mathrm{S}$ & $\mathrm{S}$ \\
\hline $\mathrm{V}_{\mathrm{C}, \mathrm{N}}, \mathrm{vol} \%$ & 30.0 & 20.0 & 0 & 0 & 0 \\
\hline $\mathrm{V}_{\mathrm{C}, \mathrm{S}}, \mathrm{vol} \%$ & 5.0 & $<1$ & 0 & $<1$ & $<2$ \\
\hline $\mathrm{r}_{\mathrm{B}, \mathrm{Q}}, \mathrm{g} / \mathrm{m}^{2}$ & 0.49 & 0.42 & 0.28 & 1.83 & 0.33 \\
\hline $\mathrm{r}_{\mathrm{Na}, \mathrm{Q}}, \mathrm{g} / \mathrm{m}^{2}$ & 0.76 & 0.64 & 0.37 & 0.88 & 0.31 \\
\hline $\mathrm{r}_{\mathrm{B}, \mathrm{C}}, \mathrm{g} / \mathrm{m}^{2}$ & 4.98 & 1.88 & 0.27 & 1.39 & 0.37 \\
\hline $\mathrm{r}_{\mathrm{Na}, \mathrm{C}}, \mathrm{g} / \mathrm{m}^{2}$ & 2.61 & 1.16 & 0.46 & 0.77 & 0.50 \\
\hline
\end{tabular}

Notes: $W$ waste loading, $W^{\prime}$ adjusted waste loading, $T_{m}$ melting temperature, $\eta_{1150}$ viscosity at $1,150{ }^{\circ} \mathrm{C}, \mathrm{T}_{\mathrm{L}}$ liquidus temperature, $\mathrm{P}$ primary crystalline phase, $\mathrm{S}$ spinel $(\mathrm{Ni}, \mathrm{Fe})(\mathrm{Fe}, \mathrm{Cr})_{2} \mathrm{O}_{4}, \mathrm{Ag}$ silver particles detected by $\mathrm{x}$-ray diffraction (XRD), $\mathrm{V}_{\mathrm{c}}$ volume percent crystals, $Q$ quenched glass, $C$ canister centerline cooled glass, $r_{b}$ and $r_{\mathrm{Na}} 7$-day PCT normalized release of boron and sodium.

\subsubsection{Glass Formulation Development for the Caustic Washed Nominal Blend}

The caustic washed nominal blend characteristically has less $\mathrm{Al}_{2} \mathrm{O}_{3}(9.6 \mathrm{wt} \%)$ but more $\mathrm{Fe}_{2} \mathrm{O}_{3}(29.2 \mathrm{wt} \%)$ and $\mathrm{Na}_{2} \mathrm{O}(24 \mathrm{wt} \%)$ than the water washed blend. Based on current models, the maximum waste loading is about $53 \mathrm{wt} \%$ in glass, as indicated by $T_{L}$ constraints. Two separate glasses were formulated from this waste, representing the bounding composition limits for this blend, Table 6-5. The first glass, referred to as nomc-1 with $51 \mathrm{wt} \%$ waste $(\mathrm{W})$, was found to be crystal free when quenched from $1,150{ }^{\circ} \mathrm{C}$ and had a few spinel crystals and noble metal particles after 24 hours at $1,050^{\circ} \mathrm{C}$. The spinel crystals, residues from the melting reaction, dissolved after prolonged heat treatment. The nomc-2 glass with $43 \mathrm{wt} \%$ waste was also crystal free at $1,150{ }^{\circ} \mathrm{C}$ and after 24 hours at $1,050{ }^{\circ} \mathrm{C}$. 
The $\mathrm{T}_{\mathrm{m}}$ of the nomc-1 glass was found to be $1,195^{\circ} \mathrm{C}, 45^{\circ} \mathrm{C}$ above the expected value based on the Arrhenius first-order viscosity model but close to the estimated value from the Fulcher first-order model (Section 5-3, Table 5-4). Normalized boron and sodium releases from quenched glass $\left(0.5\right.$ and $\left.0.64 \mathrm{~g} / \mathrm{m}^{2}\right)$ were lower than predicted $\left(1.72\right.$ and $\left.0.77 \mathrm{~g} / \mathrm{m}^{2}\right)$. Canister centerline cooled glass produced approximately 2 vol\% spinel. Normalized releases of boron and sodium from CCC glass $\left(0.58\right.$ and $\left.0.67 \mathrm{~g} / \mathrm{m}^{2}\right)$ indicated a slight decrease in durability as a function of $\mathrm{CCC}$ cooling. The $\mathrm{T}_{\mathrm{L}}$ of the glass was determined to be $1,005{ }^{\circ} \mathrm{C}$ $\left(37^{\circ} \mathrm{C}\right.$ below the predicted value of $1,042{ }^{\circ} \mathrm{C}$ ). Silver alloy colloidal particles precipitated from the glass after 1 hour at $1,150^{\circ} \mathrm{C}$ and disappeared as in previous samples after further annealing at this temperature.

The $\mathrm{T}_{\mathrm{m}}$ of the nomc- 2 glass, at $1,167^{\circ} \mathrm{C}$, was $17^{\circ} \mathrm{C}$ above the predicted value for this composition. Normalized releases of boron and sodium from quenched glass $(0.41$ and $\left.0.42 \mathrm{~g} / \mathrm{m}^{2}\right)$ were lower than predicted $\left(1.23\right.$ and $\left.0.81 \mathrm{~g} / \mathrm{m}^{2}\right)$. Canister centerline cooled glass produced about $1.8 \mathrm{vol} \%$ spinel and $0.2 \mathrm{vol} \%$ silver, producing a slight decrease in durability (normalized boron and sodium releases of 0.54 and $0.56 \mathrm{~g} / \mathrm{m}^{2}$, respectively). The $\mathrm{T}_{\mathrm{L}}$ was determined to be $998{ }^{\circ} \mathrm{C}$ (that matches the predicted value) with spinel as the primary phase as expected. Silver alloy streaks were observed in glasses quenched from $1,150{ }^{\circ} \mathrm{C}$ after 1 to 2 hours at this temperature. Both glasses (nomc-1 and nomc-2) were found to have acceptable properties for the LTM. From these results, it appears that the maximum oxide waste loading (W) for this composition is $51 \mathrm{wt} \%$ in glass.

\subsubsection{Glass Formulation development for the Water Washed AZ Blend}

This waste (water washed neutralized current acid waste from Tanks $241-\mathrm{AZ}-101$ and 241-AZ-102) has a considerable amount of $\mathrm{Al}_{2} \mathrm{O}_{3}(17.4 \mathrm{wt} \%), \mathrm{Fe}_{2} \mathrm{O}_{3}(36.6 \mathrm{wt} \%)$ and $\mathrm{Na}_{2} \mathrm{O}$ (19.2 wt \%). The maximum waste oxide loading is projected to be $43 \mathrm{wt} \%$, based on $T_{L}$ limits of the glass. Five glasses (AZ-1, $-2,-3,-4$, and -5 ) were initially formulated to represent the expected composition range for this blend (Table 6-3). The first glass (AZ-1) with $41 \mathrm{wt} \%$ waste contained a few spinel crystals at $1,150{ }^{\circ} \mathrm{C}$ but was significantly crystallized after 24 hours at $1,050{ }^{\circ} \mathrm{C}$. Glasses $\mathrm{AZ}-2,-3$, and -5 did not show any evidence of crystallinity at $1,150^{\circ} \mathrm{C}$. The second glass (AZ-2) with $38 \mathrm{wt} \%$ waste was slightly crystallized (with mostly noble metals), while the third glass (AZ-3) also with 38 wt\% waste and the fifth glass (AZ-5) with $32 \mathrm{wt} \%$ waste were crystal free after 24 hours at $1,050^{\circ} \mathrm{C}$. However, the fourth glass (AZ-4) with $32 \mathrm{wt} \%$ waste contained spinel at the melting temperature $\left(1,150{ }^{\circ} \mathrm{C}\right)$ and also at $1,050^{\circ} \mathrm{C}$ after 24 hours. Two of these glasses (AZ-3 and $\mathrm{AZ}-5$ ) were selected for further evaluation, the results of which are summarized in Table 6-6, with symbols identical to those used in Table 6-5.

The AZ-1 and AZ-3 glasses were similar, except for slight differences in the $\mathrm{Fe}_{2} \mathrm{O}_{3}$, $\mathrm{Al}_{2} \mathrm{O}_{3}$ and $\mathrm{Na}_{2} \mathrm{O}$ that produced crystals in the AZ-1 glass, Table 6-4. The AZ-2 glass was also similar to the AZ-3 glass, except for higher $\mathrm{B}_{2} \mathrm{O}_{3}$ and small differences in $\mathrm{SiO}_{2}$ and $\mathrm{Na}_{2} \mathrm{O}$, all of which had a negative impact on the liquidus temperature of the $\mathrm{AZ}-2$ glass. Glass four (AZ-4) apparently produced crystals at $1,150{ }^{\circ} \mathrm{C}$, and again at $1,050{ }^{\circ} \mathrm{C}$, because 
of high $\mathrm{B}_{2} \mathrm{O}_{3}$ and low $\mathrm{Na}_{2} \mathrm{O}$ content. These examples are important because they illustrate that small differences in composition can have an important effect on the crystallization behavior of the glass.

The $\mathrm{T}_{\mathrm{m}}$ of AZ-3 glass $\left(1,179{ }^{\circ} \mathrm{C}\right)$ was $51{ }^{\circ} \mathrm{C}$ above the predicted value based on the Arrhenius and Fulcher first-order viscosity models. Normalized boron release from quenched glass $\left(0.46 \mathrm{~g} / \mathrm{m}^{2}\right)$ was significantly lower than the predicted value for this composition $\left(2.0 \mathrm{~g} / \mathrm{m}^{2}\right)$, while the normalized sodium release from this sample $\left(0.78 \mathrm{~g} / \mathrm{m}^{2}\right)$ was close to the expected value $\left(0.71 \mathrm{~g} / \mathrm{m}^{2}\right)$. After CCC this glass produced $2.0 \mathrm{vol} \%$ spinel. Normalized boron and sodium releases from the CCC glass $\left(0.66\right.$ and $\left.0.7 .1 \mathrm{~g} / \mathrm{m}^{2}\right)$ were similar to those from the quenched glass. The $T_{L}$ was determined to be $1,048{ }^{\circ} \mathrm{C}$ $\left(22{ }^{\circ} \mathrm{C}\right.$ above the predicted value) with spinel the primary phase as expected. No color streaks were observed in samples of AZ-3 glass.

The $\mathrm{T}_{\mathrm{m}}$ of AZ-5 glass was $1,155^{\circ} \mathrm{C}$, only $5^{\circ} \mathrm{C}$ above the predicted value. Normalized boron and sodium releases from quenched glass were 0.41 and $0.43 \mathrm{~g} / \mathrm{m}^{2}$ and from CCC glass 0.43 and $0.54 \mathrm{~g} / \mathrm{m}^{2}$, respectively. These values were lower than the predicted release rates for this glass, 2.0 and $0.79 \mathrm{~g} / \mathrm{m}^{2}$, respectively. During canister centerline cooling, this glass formed less than 1 vol\% spinel. The $T_{L}$ for this composition was $953{ }^{\circ} \mathrm{C}$ ( within $3{ }^{\circ} \mathrm{C}$ of the predicted value of $956{ }^{\circ} \mathrm{C}$ ) with spinel again as the primary phase. Silver alloy colloidal particles formed after 1 hour in the molten glass but disappeared with further heating. Based on these data, the maximum waste loading for the water washed $\mathrm{AZ}$ blend (W) appears to be about $38 \mathrm{wt} \%$ in glass.

\subsubsection{Glass Formulation Development for the Water Washed 241-C-106A Tank Waste}

The Weiss analysis indicates the 241-C-106 tank waste has a considerable inventory of $\mathrm{Al}_{2} \mathrm{O}_{3}(16.2 \mathrm{wt} \%), \mathrm{Fe}_{2} \mathrm{O}_{3}(15.6 \mathrm{wt} \%), \mathrm{Na}_{2} \mathrm{O}$ (25.2 wt \%), and $\mathrm{SiO}_{2}$ (31.8 wt\%), Table 6-1. The maximum waste loading is projected to be $85 \mathrm{wt} \%$, limited by either reduced durability (caused by nepheline precipitation during canister cooling) or by $T_{L}$ (spinel crystallization in the melter). Four glasses (C106A-1,-2,-3 and-4) were initially formulated to represent the composition range for this waste. It was determined that all of these glasses were crystal free at $1,150{ }^{\circ} \mathrm{C}$ and all except C106A-1 (with 85 wt \% waste loading that produced a substantial amount of spinel) were also crystal free after 24 hours at $1,050^{\circ} \mathrm{C}$. After CCC cooling, glass C106A-2 with $80 \mathrm{wt} \%$ waste was substantially crystallized, precipitating nepheline and spinel; glass C106A-3 with 75 wt \% waste produced nepheline and less than 1 vol\% spinel; while glass C106A-4 with 58 wt\% waste was crystal free. Glasses C106A-2, C106A-3, and C106A-4 were further characterized and the results are summarized in Table 6-7 (with the same symbols as Table 6-5, except for $\mathrm{H}$ that refers to the hematite phase). Silver colloid precipitation was not observed in these glasses.

The $\mathrm{T}_{\mathrm{m}}$ of the $\mathrm{C} 106 \mathrm{~A}-2$ glass $\left(1,190^{\circ} \mathrm{C}\right)$ was $40^{\circ} \mathrm{C}$ above the estimated value based on the Arrhenius first-order viscosity model but close to the value derived from the Fulcher first-order model (Table 5-4). Normalized boron and sodium releases from quenched glass 
$\left(0.49\right.$ and $\left.0.76 \mathrm{~g} / \mathrm{m}^{2}\right)$ were found to be in reasonable agreement with predicted values $(0.44$ and $0.34 \mathrm{~g} / \mathrm{m}^{2}$ ). Canister centerline cooling precipitated about $30 \mathrm{vol} \%$ nepheline and $5 \mathrm{vol} \%$ spinel and caused a substantial increase in normalized releases of boron and sodium $\left(4.98\right.$ and $\left.2.61 \mathrm{~g} / \mathrm{m}^{2}\right)$, thus signifying a significant decrease in durability (to nearly 70 percent of the allowable $B$ limit for the DWPF EA glass). The measured $T_{L}$ was $1,004{ }^{\circ} \mathrm{C}$ (slightly below the predicted value of $1,011^{\circ} \mathrm{C}$ ) with spinel as the primary crystalline phase.

For glass $\mathrm{C} 106 \mathrm{~A}-3$, the $\mathrm{T}_{\mathrm{m}}$ was $1,177^{\circ} \mathrm{C}, 57^{\circ} \mathrm{C}$ higher than predicted. Normalized releases of boron and sodium from quenched glass $\left(0.42\right.$ and $\left.0.64 \mathrm{~g} / \mathrm{m}^{2}\right)$ were.close to those predicted $\left(0.49\right.$ and $\left.0.47 \mathrm{~g} / \mathrm{m}^{2}\right)$. After canister centerline cooling, $20 \mathrm{vol} \%$ nepheline was detected in the glass. Precipitation of nepheline caused increased normalized boron and sodium releases from the CCC glass $\left(1.88\right.$ and $\left.1.16 \mathrm{~g} / \mathrm{m}^{2}\right)$, thus indicating a significant decrease in durability (to about 26 percent of the allowable B limit for DWPF glass). The measured $\mathrm{T}_{\mathrm{L}}$ was $1,029^{\circ} \mathrm{C}$ (nearly $50{ }^{\circ} \mathrm{C}$ above the predicted value of $979^{\circ} \mathrm{C}$ ) with a spinel phase as the primary crystalline phase.

Glass C106A-4 had a $\mathrm{T}_{\mathrm{m}}$ of $1,160^{\circ} \mathrm{C}, 10^{\circ} \mathrm{C}$ above the Arrhenius predicted value for this glass. Normalized boron and sodium releases for quenched glass were 0.28 and $0.37 \mathrm{~g} / \mathrm{m}^{2}$ and changed little after canister centerline cooling $\left(0.27\right.$ and $\left.0.46 \mathrm{~g} / \mathrm{m}^{2}\right)$. These values are in reasonable agreement with predicted values $\left(0.56\right.$ and $\left.0.47 \mathrm{~g} . / \mathrm{m}^{2}\right)$. The $T_{L}$ was determined to be $885{ }^{\circ} \mathrm{C}\left(42{ }^{\circ} \mathrm{C}\right.$ below the predicted value) with a spinel phase as the primary crystalline phase.

Normalized boron and sodium releases from canister centerline cooled C106A-2 and C106A-3 glasses appear to be acceptable based on the WAPS 1.3 acceptance criteria defined by DWPF (two standard deviations below the mean PCT results of the EA glass, Table 5-8). Based on these results, the maximum achievable loading for 241-C-106A waste (W) appears to lie in the range from 75 to $80 \mathrm{wt} \%$, but could be as low as $58 \mathrm{wt} \%$ if limits are imposed on the amount of nepheline in the HLW form.

\subsubsection{Glass Formulation Development for the Water Washed 241-C-106B Tank Waste}

The 241-C-106B (Hara) tank waste composition estimate is high in $\mathrm{Al}_{2} \mathrm{O}_{3}(35.6 \mathrm{wt} \%$ ), $\mathrm{Fe}_{2} \mathrm{O}_{3}(19.3 \mathrm{wt} \%)$ and $\mathrm{Na}_{2} \mathrm{O}(29.2 \mathrm{wt} \%)$. The maximum waste loading is estimated to be $45 \mathrm{wt} \%$, limited by reduced durability (caused by nepheline precipitation during canister cooling). Two glasses, labeled C106B-1 and C106B-2, were formulated to represent the bounding conditions for this waste. Both glasses were observed to be crystal free after 24 hours at $1,050^{\circ} \mathrm{C}$. Glass C106B-1 with $45 \mathrm{wt} \%$ waste produced less than $2 \mathrm{vol} \%$ spinel after canister cooling, while glass C106B-2 with $41 \mathrm{wt} \%$ waste contained less than $1 \mathrm{vol} \%$ spinel after CCC cooling. These glasses were further characterized and the results are summarized in Table 6-7. 
The $\mathrm{T}_{\mathrm{m}}$ of C106B-1 glass was measured to be $1,131^{\circ} \mathrm{C}, 19^{\circ} \mathrm{C}$ below the predicted value. Normalized releases of boron and sodium from quenched glass were 1.83 and $0.88 \mathrm{~g} / \mathrm{m}^{2}$, that are agreeably close to the predicted values $\left(1.73\right.$ and $\left.0.69 \mathrm{~g} / \mathrm{m}^{2}\right)$. After canister centerline cooling, this glass was found to have less than $1 \mathrm{vol} \%$ spinel, that did not effect normalized releases of boron and sodium $\left(1.39\right.$ and $\left.0.77 \mathrm{~g} / \mathrm{m}^{2}\right)$. The $T_{L}$ was determined to be $986{ }^{\circ} \mathrm{C}$ (only $13{ }^{\circ} \mathrm{C}$ below the predicted value of $999{ }^{\circ} \mathrm{C}$ ) with spinel and hematite as the main phases. No evidence of silver colloid was found in the quenched glass after 1 hour at $1,150^{\circ} \mathrm{C}$, but significant streaking, typical for silver colloid, occurred after 2 hours at the same temperature. Similar streaking has also been observed in the DWPF radioactive glasses due to copper precipitation (where copper. is added as a catalyst in the DWPF salt processing cell).

The $\mathrm{T}_{\mathrm{m}}$ of $\mathrm{C} 106 \mathrm{~B}-2$ glass was $1,153{ }^{\circ} \mathrm{C}$, only $3{ }^{\circ} \mathrm{C}$ above the initial projection. Normalized boron and sodium releases from quenched glass $\left(0.33\right.$ and $\left.0.31 \mathrm{~g} / \mathrm{m}^{2}\right)$ and for CCC glass $\left(0.37\right.$ and $\left.0.5 \mathrm{~g} / \mathrm{m}^{2}\right)$ were reasonably close to the predicted values $(0.58$ and $0.27 \mathrm{~g} / \mathrm{m}^{2}$ ). The measured $T_{\mathrm{L}}$ was $894^{\circ} \mathrm{C}$ (slightly above the predicted value of $877^{\circ} \mathrm{C}$ ) with a spinel phase as the primary phase in the molten glass. The maximum waste loading (W) for this composition appears to be about $45 \mathrm{wt} \%$ in glass based on durability properties of the quenched sample.

\subsection{GLASS VOLUME PREDICTIONS}

With better spinel and nepheline models, the glass formulation models can now be used to test the bounding glass composition limits for each of the Phase I cases. Examples will be presented of the glass formulation methodology used to evaluate each of the Phase I glasses. The main purpose of this exercise is to estimate bounding conditions for each waste and the effects of retrieval sequence, blending strategy or pretreatment process on the number of canisters produced. To evaluate sensitivities, composition boundaries were evaluated by increasing the allowable liquidus temperature or by assuming that part of the $\mathrm{Al}_{2} \mathrm{O}_{3}$ and $\mathrm{Na}_{2} \mathrm{O}$ could be removed (by caustic washing) and the glass reformulated to the maximum WOL. The impact of underestimating or overestimating the concentration of other components in the waste was also evaluated $\left(\mathrm{Fe}_{2} \mathrm{O}_{3}, \mathrm{Cr}_{2} \mathrm{O}_{3}, \mathrm{MnO}_{2}\right.$, and $\left.\mathrm{Al}_{2} \mathrm{O}_{3}\right)$. The models that will be used include the Fulcher first-order viscosity model (Table 5-4), spinel second-order liquidus temperature model (Table 5-8), second-order B and Na PCT release models (Table 5-9) and the nepheline model (Section 5.6, Figure 5-5).

\subsubsection{Bounding Composition Limits for the (Water Washed) Nominal Blend Glass}

The water washed nominal blend was previously defined in Table 6-1, and the glasses developed from this waste in Tables 6-2 and 6-5. Based on the glass formulation studies to date, the optimum formulation appears to be the nom-3 glass described in Table 6-5 (with the maximum waste oxide loading (WOL) of $48 \mathrm{wt} \%$ in glass). The glass formulation models were used to estimate the properties of the baseline (nom-3) glass, and changes induced by: 
(1) raising the WOL and allowable liquidus temperature, (2) gradually reducing the amount of $\mathrm{Al}_{2} \mathrm{O}_{3}$ and $\mathrm{Na}_{2} \mathrm{O}$, and (3) increasing or decreasing the amount of $\mathrm{Fe}_{2} \mathrm{O}_{3}, \mathrm{Cr}_{2} \mathrm{O}_{3}$ and $\mathrm{MnO}$ in this waste. All of the glasses were formulated to a meet a target viscosity range of 4 to $6 \mathrm{~Pa}$-s in the melter $\left(1,150^{\circ} \mathrm{C}\right)$ and acceptable durability. The liquidus temperature of the base case (nom-3) glass is $1,047{ }^{\circ} \mathrm{C}$, only $4{ }^{\circ} \mathrm{C}$ below the predicted value derived from the spinel model. The results are summarized in Table 6-8, with the following symbols: WOL waste oxide loading, Mass of glass (in MT), Cans showing the number of standard DWPF canisters of glass, $T_{L}$ liquidus temperature of spinel, $r_{B}$ and $r_{\mathrm{Na}}$ 7-day PCT normalized release of boron and sodium.

Table 6-8 shows the property changes that occur as the WOL and liquidus temperature limit are raised and $\mathrm{Al}_{2} \mathrm{O}_{3}$ and $\mathrm{Na}_{2} \mathrm{O}$ concentrations are reduced in the baseline (nom-3) glass. Based on these conditions, it appears that 75 canisters of glass could be saved if the liquidus temperature limit is raised to $1,150^{\circ} \mathrm{C}$ (an impractical upper limit), or 53 canisters saved if the $T_{L}$ limit is raised to $1,100^{\circ} \mathrm{C}$. This may be an attractive option if a new spinel model (with $\pm 25^{\circ} \mathrm{C}$ uncertainty) is used as a basis for reducing the liquidus temperature margin for glass formulation or if methods are developed to remedy spinel phase accumulation problems in the melter. If $T_{L}$ is raised to $1,100{ }^{\circ} \mathrm{C}$, the repository disposal fee for this waste could be reduced $\$ 18.9$ million, based on $\$ 356,000$ per canister (DOE 1995).

Table 6-8. Development of Bounding Composition Limits for the (Water Washed) Nominal Blend Glass.

\begin{tabular}{|c|c|c|c|c|c|c|c|c|}
\hline Step & $\begin{array}{c}\text { WOL, } \\
\text { wt\% }\end{array}$ & $\begin{array}{c}\text { Mass, } \\
\text { MT }\end{array}$ & Cans $^{\mathrm{c}}$ & $\begin{array}{c}\mathrm{Fe}_{2} \mathrm{O}_{3}, \\
w^{\%}\end{array}$ & $\begin{array}{c}\mathrm{Al}_{2} \mathrm{O}_{3}, \\
\mathrm{wt} \%\end{array}$ & $\mathrm{~T}_{\mathrm{L}},{ }^{\circ} \mathrm{C}$ & $\begin{array}{c}\mathbf{r}_{\mathrm{B}}, \\
\mathrm{g} / \mathrm{m}^{2}\end{array}$ & $\begin{array}{c}\mathrm{r}_{\mathrm{Na}}, \\
\mathrm{g} / \mathrm{m}^{2}\end{array}$ \\
\hline Nom-3 Glass & 48.49 & 817.4 & 495 & 12.41 & 9.16 & $1,051^{\mathrm{a}}$ & 0.78 & 0.32 \\
\hline Incre.WOL \& $\mathrm{T}_{\mathrm{L}}$ & 54.34 & 729.3 & 442 & 13.91 & 10.27 & $1,101^{\mathrm{a}}$ & 0.52 & 0.17 \\
\hline Incre.WOL \& $\mathrm{T}_{\mathrm{L}}$ & 57.21 & 692.8 & 420 & 14.64 & 10.81 & $1,150^{\mathrm{a}}$ & 0.37 & 0.11 \\
\hline Red.Al 25\% & 47.28 & 798.6 & 484 & 12.70 & 7.03 & 1,015 & 1.35 & 0.80 \\
\hline Red.Na & 47.88 & 788.6 & 478 & 12.86 & 7.12 & 1,034 & 1.07 & 0.63 \\
\hline Red.Al 35\% & 47.38 & 781.1 & 473 & 12.99 & 6.23 & 1,019 & 1.39 & 0.92 \\
\hline Red.Al 50\% & 46.62 & 769.9 & 467 & 13.18 & 4.86 & 997 & $2.15^{\text {b }}$ & 1.68 \\
\hline Red.Na & 47.86 & 749.9 & 455 & 13.53 & 4.99 & 1,040 & 1.33 & 1.03 \\
\hline Red.Al 60\% & 47.33 & 742.4 & 450 & 13.66 & 4.04 & 1,025 & 1.84 & 1.55 \\
\hline Red.Al 75\% & 46.52 & 731.2 & 443 & 13.87 & 2.56 & 1,003 & $3.15^{\mathrm{b}}$ & 2.94 \\
\hline Red.Na \& Li & 47.73 & 712.7 & 432 & 14.32 & 2.63 & 1,040 & $1.98^{\mathrm{b}}$ & 1.05 \\
\hline
\end{tabular}

${ }^{a}$ Limited by liquidus temperature $\left(\mathrm{T}_{\mathrm{L}}<1,050{ }^{\circ} \mathrm{C}\right)$.

${ }^{b}$ Limited by durability $\left(\mathrm{r}_{\mathrm{B}}<2.0 \mathrm{~g} / \mathrm{m}^{2}\right)$.

${ }^{c}$ Defense Waste Processing Facility canisters $(1,650 \mathrm{~kg}$ of glass per canister). 
The glass formulation models also show that another 63 canisters of glass could be saved if the $\mathrm{Al}_{2} \mathrm{O}_{3}$ concentration is reduced by 75 percent in the waste. In this case, the minimum $\mathrm{Al}_{2} \mathrm{O}_{3}$ concentration is controlled by the durability and liquidus temperature properties of the glass, and not by nepheline precipitation in the canister (normalized $\mathrm{SiO}_{2}>$ $0.7118)$. Since $\mathrm{B}$ and $\mathrm{Na} P C T$ release rates $\left(\mathrm{r}_{\mathrm{B}}\right.$ and $\left.\mathrm{r}_{\mathrm{Na}}\right)$ increase as $\mathrm{Al}_{2} \mathrm{O}_{3}$ is reduced, $\mathrm{Na}_{2} \mathrm{O}$ and $\mathrm{Li}_{2} \mathrm{O}$ also need to be reduced to meet the durability constraints for this glass (release rates of less than $2.0 \mathrm{~g} / \mathrm{m}^{2}$ ). The optimum glass, with $2.63 \mathrm{wt} \% \mathrm{Al}_{2} \mathrm{O}_{3}$, appears to have acceptable viscosity, liquidus temperature and durability properties (viscosity $5.3 \mathrm{~Pa}-\mathbf{s}, \mathrm{T}_{\mathbf{L}}$ $1,040{ }^{\circ} \mathrm{C}$ and $\left.r_{B}<2.0 \mathrm{~g} / \mathrm{m}^{2}\right)$. If 63 canisters of glass could be saved, this would translate to a repository cost savings of $\$ 22.4$ million, based on $\$ 356,000$ per canister (DOE 1995). Over this $\mathrm{Al}_{2} \mathrm{O}_{3}$ range, the WOL changes very little (only 1.5 percent) as the quantity of glass is reduced by 15 percent.

The base case (nom-3) glass contains $12.41 \mathrm{wt} \% \mathrm{Fe}_{2} \mathrm{O}_{3}, 0.18 \mathrm{wt} \% \mathrm{Cr}_{2} \mathrm{O}_{3}, 0.4 \mathrm{wt} \%$ $\mathrm{MnO}$ and $9.16 \mathrm{wt} \% \mathrm{Al}_{2} \mathrm{O}_{3}$. The liquidus temperature is projected to increase (or decrease) about $29{ }^{\circ} \mathrm{C}$ for a $0.1 \mathrm{wt} \%$ change in $\mathrm{Cr}_{2} \mathrm{O}_{3}, 6{ }^{\circ} \mathrm{C}$ for $\mathrm{MnO}, 2.2{ }^{\circ} \mathrm{C}$ for $\mathrm{Fe}_{2} \mathrm{O}_{3}$ and $1.6{ }^{\circ} \mathrm{C}$ for $\mathrm{Al}_{2} \mathrm{O}_{3} \cdot \mathrm{Cr}_{2} \mathrm{O}_{3}$ obviously has a dominate effect on liquidus temperature, while $\mathrm{Fe}_{2} \mathrm{O}_{3}$ and $\mathrm{Al}_{2} \mathrm{O}_{3}$ have roughly equivalent effects on $T_{L}$.

\subsubsection{Bounding Composition Limits for the (Caustic Washed) Nominal Blend Glass}

The caustic washed nominal blend is also described in Table 6-1, while the simulant glasses made from this waste are described in Tables 6-2 and 6-5. The optimum formulation appears to be the nomc-1 glass, limited by the few spinel crystals observed in this glass after 24 hours at $1,050^{\circ} \mathrm{C}$. The current set of glass formulation models was used to estimate the properties of this glass, as well as changes induced by: (1) raising the WOL and liquidus temperature, (2) reducing the amount of $\mathrm{Al}_{2} \mathrm{O}_{3}$ and $\mathrm{Na}_{2} \mathrm{O}$ and (3) increasing or decreasing the amount of $\mathrm{Fe}_{2} \mathrm{O}_{3}, \mathrm{Cr}_{2} \mathrm{O}_{3}$ and $\mathrm{MnO}$ in this waste. All of the glasses were formulated to a meet a target viscosity range of 5 to $7 \mathrm{~Pa}$-s (except the baseline nomc-1 glass which experimentally had a viscosity of $7.6 \mathrm{~Pa}-\mathrm{s}$ at $1,150{ }^{\circ} \mathrm{C}$ ). The liquidus temperature of the nomc-1 glass is $1,005{ }^{\circ} \mathrm{C}$, about $41{ }^{\circ} \mathrm{C}$ below the predicted value for this glass. The results of this modelling effort are summarized in Table 6-9, using the same nomenclature as Table 6-5. 
Table 6-9. Development of Bounding Composition Limits for the (Caustic Washed) Nominal Blend Glass.

\begin{tabular}{|c|c|c|c|c|c|c|c|c|}
\hline Step & $\begin{array}{c}\text { WOL, } \\
\text { wt\% }\end{array}$ & $\begin{array}{c}\text { Mass, } \\
\text { MT }\end{array}$ & Cans $^{\mathrm{c}}$ & $\begin{array}{c}\mathrm{Fe}_{2} \mathrm{O}_{3}, \\
\text { wt\% }\end{array}$ & $\begin{array}{c}\mathrm{Al}_{2} \mathrm{O}_{3}, \\
\text { wt } \%\end{array}$ & $\mathrm{~T}_{\mathrm{L}},{ }^{\circ} \mathrm{C}$ & $\begin{array}{c}\mathrm{r}_{\mathrm{B}}, \\
\mathrm{g} / \mathrm{m}^{2}\end{array}$ & $\begin{array}{c}\mathrm{r}_{\mathrm{Na}} \\
\mathrm{g} / \mathrm{m}^{2}\end{array}$ \\
\hline Nomc-1 Glass & 51.94 & 688.2 & 417 & 14.74 & 5.66 & 1,046 & 1.03 & 0.74 \\
\hline Incre. WOL \& $\mathrm{T}_{\mathrm{L}}$ & 56.44 & 633.3 & 384 & 16.02 & 6.15 & $1,100^{\mathrm{a}}$ & 0.99 & 0.66 \\
\hline Incre. WOL \& $\mathrm{T}_{\mathrm{L}}$ & 59.54 & 600.3 & 364 & 16.90 & 6.49 & $1,150^{\mathrm{a}}$ & 0.91 & 0.59 \\
\hline Red.Al 25\% & 51.25 & 678.4 & 411 & 14.95 & 4.31 & $-1,025$ & 1.59 & 1.31 \\
\hline Red.Al 50\% & 50.54 & 668.7 & 406 & 15.17 & 2.91 & 1,004 & $2.59^{\mathrm{b}}$ & 2.37 \\
\hline Red.NaAdd Li & 51.27 & 659.2 & 400 & 15.39 & 2.95 & 1,029 & $2.0^{\mathrm{b}}$ & 1.83 \\
\hline Red.Al 75\% & 50.54 & 649.5 & 394 & 15.62 & 1.50 & 1,008 & $3.46^{\mathrm{b}}$ & $3.4^{\mathrm{b}}$ \\
\hline $\begin{array}{c}\text { Add Al Red.Na } \\
\text { Add Li }\end{array}$ & 50.13 & 654.8 & 397 & 15.49 & 2.10 & $1,051^{\mathrm{a}}$ & $1.99^{\mathrm{b}}$ & 1.90 \\
\hline
\end{tabular}

${ }^{a}$ Limited by liquidus temperature $\left(\mathrm{T}_{\mathrm{L}}<1,050^{\circ} \mathrm{C}\right)$.

${ }^{b}$ Limited by durability $\left(\mathrm{r}_{\mathrm{B}}<2.0 \mathrm{~g} / \mathrm{m}^{2}\right)$.

${ }^{c}$ Defense Waste Processing Facility canisters $(1,650 \mathrm{~kg}$ of glass per canister).

Table 6-9 illustrates the changes that are likely to occur as the WOL and liquidus temperature are raised and $\mathrm{Al}_{2} \mathrm{O}_{3}$ and $\mathrm{Na}_{2} \mathrm{O}$ concentrations are reduced in the nomc- 1 glass. From these results, it appears that 33 canisters of glass could be saved by reformulating the nomc-1 glass to a predicted liquidus temperature limit of $1,100{ }^{\circ} \mathrm{C}$. By reformulating the glass, approximately $\$ 11.8$ million could be saved in repository disposal costs compared to the base case nomc-1 glass. Also, 53 canisters of glass could be saved if the liquidus temperature limit (predicted $\mathrm{T}_{\mathrm{L}}$ ) is raised to $1,150{ }^{\circ} \mathrm{C}$. Because the measured $\mathrm{T}_{\mathrm{L}}$ is $41{ }^{\circ} \mathrm{C}$ less than the predicted $T_{L}$, a higher $T_{L}$ limit might be acceptable if a better liquidus temperature model is developed.

The glass models also show that another 17 to 20 canisters could be saved by removing 50 percent of the $\mathrm{Al}_{2} \mathrm{O}_{3}$ from this waste $\left(76\right.$ percent of the total amount of $\mathrm{Al}_{2} \mathrm{O}_{3}$ since caustic washed waste only contains 52 percent of the original amount of $\mathrm{Al}_{2} \mathrm{O}_{3}$ in the nominal blend feed). As $\mathrm{Al}_{2} \mathrm{O}_{3}$ is reduced, $\mathrm{Na}_{2} \mathrm{O}$ and $\mathrm{Li}_{2} \mathrm{O}$ also have to be reduced to control the durability properties of the glass. Glass formulation boundaries can be further tested by removing 75 percent of the $\mathrm{Al}_{2} \mathrm{O}_{3}$ from this waste, together with a sufficient amount of $\mathrm{Na}_{2} \mathrm{O}$ and with a small increase in $\mathrm{Li}_{2} \mathrm{O}$ to meet the acceptable viscosity, liquidus temperature and durability limits for this glass (viscosity $5.65 \mathrm{~Pa}-\mathrm{s}, \mathrm{T}_{\mathrm{L}} 1,150{ }^{\circ} \mathrm{C}$ and $\mathrm{r}_{\mathrm{B}}<2.0 \mathrm{~g} / \mathrm{m}^{2}$ ). This step, however, saves only three additional canisters of glass. The viscosity, liquidus temperature and durability properties of the glass are the bounding constraints, rather than the nepheline forming properties of these glasses (normalized $\mathrm{SiO}_{2}$ concentration $>0.7325$ ). 


\section{Revision 0}

The nomc-1 glass contains $14.74 \mathrm{wt} \% \mathrm{Fe}_{2} \mathrm{O}_{3}, 0.2 \mathrm{wt} \% \mathrm{Cr}_{2} \mathrm{O}_{3}, 0.48 \mathrm{wt} \% \mathrm{MnO}$ and $5.66 \mathrm{wt} \% \mathrm{Al}_{2} \mathrm{O}_{3}$. According to the spinel model, the liquidus temperature should increase (or decrease) about $28{ }^{\circ} \mathrm{C}$ for a $0.1 \mathrm{wt} \%$ change in $\mathrm{Cr}_{2} \mathrm{O}_{3}, 3$ to $4{ }^{\circ} \mathrm{C}$ for $\mathrm{MnO}, 2{ }^{\circ} \mathrm{C}$ for $\mathrm{Fe}_{2} \mathrm{O}_{3}$ and $1.5^{\circ} \mathrm{C}$ for $\mathrm{Al}_{2} \mathrm{O}_{3}$. The liquidus temperature response is obviously dominated by $\mathrm{Cr}_{2} \mathrm{O}_{3}$, with $\mathrm{Fe}_{2} \mathrm{O}_{3}$ and $\mathrm{Al}_{2} \mathrm{O}_{3}$ also having a significant effect.

\subsubsection{Bounding Composition Limits for the $\mathrm{AZ}$ Blend Glass}

The water washed $\mathrm{AZ}$ blend (blend from Tanks 241-AZ-101 and 241-AZ-102) was previously described in Table 6-1, and AZ blend glasses in Tables 6-4 and 6-6. From the glass formulation studies to date, the optimum formulation appears to be the AZ-3 glass described in Table 6-6 (with a maximum WOL of $38 \mathrm{wt} \%$ ). The glass formulation models were used to estimate the properties of this glass, and changes induced by: (1) raising the WOL and liquidus temperature, (2) gradually reducing the amount of $\mathrm{Al}_{2} \mathrm{O}_{3}$ and $\mathrm{Na}_{2} \mathrm{O}$, and (3) increasing or decreasing the amount of $\mathrm{Fe}_{2} \mathrm{O}_{3}, \mathrm{Cr}_{2} \mathrm{O}_{3}$, and $\mathrm{MnO}$ in this waste. All of the glasses were formulated to a meet a target viscosity range of 5 to $7 \mathrm{~Pa}$-s in the melter $\left(1,150{ }^{\circ} \mathrm{C}\right)$. The liquidus temperature of the baseline glass is $1,048{ }^{\circ} \mathrm{C}, 40^{\circ} \mathrm{C}$ above the predicted value from the spinel model. The results are summarized in Table 6-10, using the same symbols as Table 6-5. 


\section{Revision 0}

Table 6-10. Development of Bounding Composition Limits for the AZ Blend Glass.

\begin{tabular}{|c|c|c|c|c|c|c|c|c|}
\hline Step & $\begin{array}{c}\text { WOL, } \\
\text { wt \% }\end{array}$ & $\begin{array}{c}\text { Mass, } \\
\text { MT }\end{array}$ & Cans $^{\mathrm{c}}$ & $\begin{array}{c}\mathrm{Fe}_{2} \mathrm{O}_{3}, \\
\mathrm{wt} \%\end{array}$ & $\begin{array}{c}\mathrm{Al}_{2} \mathrm{O}_{3}, \\
\mathrm{wt} \%\end{array}$ & $\mathrm{~T}_{\mathrm{L}},{ }^{\circ} \mathrm{C}$ & $\begin{array}{c}\mathrm{r}_{\mathrm{B}}, \\
\mathrm{g} / \mathrm{m}^{2}\end{array}$ & $\begin{array}{c}\mathrm{r}_{\mathrm{Na}} \\
\mathrm{g} / \mathrm{m}^{2}\end{array}$ \\
\hline AZ-3 Glass & 38.55 & 732.05 & 453 & 13.55 & 6.45 & $1,008^{\mathrm{a}}$ & 1.49 & 0.96 \\
\hline Incre.WOL \& $\mathrm{T}_{\mathbf{L}}$ & 43.41 & 650.0 & 396 & 15.26 & 7.26 & $1,101^{\mathrm{a}}$ & 1.46 & 0.84 \\
\hline Incre. WOL \& $\mathrm{T}_{\mathrm{L}}$ & 44.79 & 630.1 & 382 & 15.75 & 7.49 & $1,150^{\mathrm{a}}$ & 0.78 & 0.43 \\
\hline Red.Al 25\% & 37.54 & 720.3 & 437 & 13.77 & 4.92 & 980 & $2.40^{\mathrm{b}}$ & 1.86 \\
\hline Red.Na & 38.12 & 709.37 & 430 & 13.99 & 4.99 & $1,005^{\mathrm{a}}$ & 1.77 & 1.36 \\
\hline Red.Al 50\% & 37.07 & 697.47 & 422 & 14.22 & 3.38 & 977 & $3.05^{\mathrm{b}}$ & $2.71^{\mathrm{b}}$ \\
\hline Red.Na & 37.73 & 685.3 & 415 & 14.22 & 3.38 & $1,008^{\mathrm{a}}$ & $2.16^{\mathrm{b}}$ & 1.90 \\
\hline $\begin{array}{c}\text { Red.Al 40\%, } \\
\text { Red.Na }\end{array}$ & 37.88 & 695.2 & 421 & 14.27 & 4.07 & $1,005^{\mathrm{a}}$ & 1.99 & 1.67 \\
\hline
\end{tabular}

${ }^{a}$ Limited by liquidus temperature $\left(\mathrm{T}_{\mathrm{L}}\right.$ predicted $\left.+40^{\circ} \mathrm{C}<1,050^{\circ} \mathrm{C}\right)$.

${ }^{b}$ Limited by durability $\left(\mathrm{r}_{\mathrm{B}}<2.0 \mathrm{~g} / \mathrm{m}^{2}\right)$.

${ }^{\mathrm{C}}$ Defense Waste Processing Facility canisters $(1,650 \mathrm{~kg}$ of glass per canister).

Table 6-10 shows the property changes that occur as the WOL and liquidus temperature are raised and $\mathrm{Al}_{2} \mathrm{O}_{3}$ and $\mathrm{Na}_{2} \mathrm{O}$ concentrations are reduced in the $\mathrm{AZ}-3$ glass. It appears that 61 canisters of glass could be saved if the liquidus temperature limit is raised to 1,150 ${ }^{\circ} \mathrm{C}$ and 47 canisters if the $\mathrm{T}_{\mathrm{L}}$ limit is raised to $1,100{ }^{\circ} \mathrm{C}$ (conditions which are unacceptable because the measured $\mathrm{T}_{\mathrm{L}}$ is $40^{\circ} \mathrm{C}$ above the predicted value). This example illustrates the importance of having a reliable liquidus temperature model for prediction, but also shows the possible advantages to be gained by raising the $T_{L}$ limit and reducing the liquidus temperature margin for glass formulation.

The glass models also show that only about 13 canisters of glass could be saved by

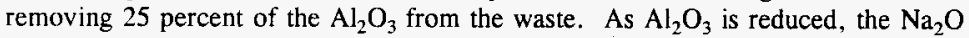
concentration also must be reduced to control the durability characteristics of the glass. The boundaries can be further tested by removing 50 percent of the $\mathrm{Al}_{2} \mathrm{O}_{3}$ in the waste. This new glass is predicted to have unacceptable durability properties $\left(\mathrm{r}_{\mathrm{B}}>2.0 \mathrm{~g} / \mathrm{m}^{2}\right)$. An attempt was made to correct this condition by reducing the $\mathrm{Na}_{2} \mathrm{O}$ concentration of the glass. The results show that the maximum $T_{L}$ limit is reached before the durability release rates, as measured by $r_{B}$, can be brought into alignment with the target value $\left(r_{B}<2.0 \mathrm{~g} / \mathrm{m}^{2}\right)$. Furthermore, the final viscosity was found to be too high (7.15 Pa-s versus the targeted range of 5 to $7 \mathrm{~Pa}$-s). If $\mathrm{Na}_{2} \mathrm{O}$ or $\mathrm{Li}_{2} \mathrm{O}$ were reduced to correct the durability problem, the glass viscosity would increase to a totally unacceptable value. The other choice would be to increase the amount of $\mathrm{SiO}_{2}$ or $\mathrm{Al}_{2} \mathrm{O}_{3}$ in the glass, but these measures would also increase both the viscosity of the glass and the total number of canisters produced. The optimum 
glass appears to one in which 40 percent of the $\mathrm{Al}_{2} \mathrm{O}_{3}$ has been removed from the waste and the $\mathrm{Na}_{2} \mathrm{O}$ concentration has been reduced to a level where the viscosity and durability properties of the glass are marginally acceptable (viscosity of $6.97 \mathrm{~Pa}-\mathrm{s}$ and $\mathrm{r}_{\mathrm{B}}<2.0 \mathrm{~g} / \mathrm{m}^{2}$ ). From this analysis, approximately 22 canisters of glass could be saved by reformulating the AZ-3 glass to the edge of the viscosity and durability envelopes. This result also shows that caustic washing is only marginally effective and in all probability should not be considered for the Tanks 241-AZ-101 and 241-AZ-102 wastes if the current waste composition estimates are accurate.

The AZ-3 glass contains $13.55 \mathrm{wt} \% \mathrm{Fe}_{2} \mathrm{O}_{3}, 0.17 \mathrm{wt} \% \mathrm{Cr}_{2} \mathrm{O}_{3}, 0.37 \mathrm{wt} \% \mathrm{MnO}$, and $6.45 \mathrm{wt} \% \mathrm{Al}_{2} \mathrm{O}_{3}$. Based on the present spinel model, the liquidus temperature will increase (or decrease) about $29^{\circ} \mathrm{C}$ for a $0.1 \mathrm{wt} \%$ increase (or decrease) in $\mathrm{Cr}_{2} \mathrm{O}_{3}, 4.8^{\circ} \mathrm{C}$ for $\mathrm{MnO}$, $2.2^{\circ} \mathrm{C}$ for $\mathrm{Fe}_{2} \mathrm{O}_{3}$, and $1.7^{\circ} \mathrm{C}$ for $\mathrm{Al}_{2} \mathrm{O}_{3}$. The liquidus temperature is most strongly affected by $\mathrm{Cr}_{2} \mathrm{O}_{3}$, with somewhat smaller effects attributable to $\mathrm{MnO}, \mathrm{Fe}_{2} \mathrm{O}_{3}$, and $\mathrm{Al}_{2} \mathrm{O}_{3}$.

\subsubsection{Bounding Composition Limits for the 241-C-106A Glass}

The water washed 241-C-106A waste composition is presented in Table 6-1, and potential glasses made from this waste in Tables 6-3 and 6-7. The 241-C-106A composition was derived from the Weiss analysis of the 1986 core sample, and as such is probably the most representative composition profile for this tank. Recently, a number of grab samples were taken from six different elevations in the tank $(35$ to $76 \mathrm{~cm}$. below the top surface of the sludge). The ratio of $\mathrm{Al}$ to $\mathrm{Fe}$ in these samples generally matches the expected profile for 241-C-106A waste (while the Si concentrations were found to be only 38 percent of the expected 241-C-106A value). Because glass properties are generally controlled by the amount of $\mathrm{Al}$ and $\mathrm{Fe}$ in the waste, the 241-C-106A waste profile and glasses derived from this profile are most likely to be representative of actual Phase I glass.

The C106A-4 glass (58 wt \% WOL) was chosen for initial glass formulation development because this glass did not produce nepheline in the canister centerline cooled sample. From experimental glass studies, it appears the maximum achievable waste loading could be as high as 75 to $80 \mathrm{wt} \%$ if 20 to $30 \mathrm{vol} \%$ nepheline is acceptable at the canister centerline (in which case C106A-2 and C106A-3 glasses would represent the bounding conditions for this waste). The glass formulation models were used to estimate the properties of the C106A-4 glass and changes caused by: (1) raising the WOL to the nepheline and liquidus temperature limits, (2) reducing the amount of $\mathrm{Al}_{2} \mathrm{O}_{3}$ and $\mathrm{Na}_{2} \mathrm{O}$, and (3) increasing or decreasing the amount of $\mathrm{Fe}_{2} \mathrm{O}_{3}, \mathrm{Cr}_{2} \mathrm{O}_{3}$, and $\mathrm{MnO}$ in this waste. All of the glasses were formulated to a meet a target viscosity range of 4 to $6.5 \mathrm{~Pa}$-s in the melter $\left(1,150{ }^{\circ} \mathrm{C}\right)$. The liquidus temperature of the $\mathrm{C} 106 \mathrm{~A}-4$ glass is $885{ }^{\circ} \mathrm{C}$, about $38{ }^{\circ} \mathrm{C}$ below the predicted value for this glass $\left(923{ }^{\circ} \mathrm{C}\right)$. The results are summarized in Table 6-11, using the same nomenclature as Table 6-5, except for the defined nepheline region (which indicates whether the glass resides in the defined nepheline region as determined by the normalized $\mathrm{SiO}_{2}$ concentration). 


\section{Revision 0}

Table 6-11. Development of Bounding Composition Limits for the 241-C-106A Glass.

\begin{tabular}{|c|c|c|c|c|c|c|c|c|c|}
\hline Step & $\begin{array}{c}\text { WOL, } \\
\text { wt\% }\end{array}$ & $\begin{array}{c}\text { Mass, } \\
\mathrm{MT}\end{array}$ & $\mathrm{Cans}^{\mathrm{c}}$ & $\begin{array}{c}\mathrm{Fe}_{2} \mathrm{O}_{3}, \\
\mathrm{wt} \%\end{array}$ & $\begin{array}{c}\mathrm{Al}_{2} \mathrm{O}_{3}, \\
\mathrm{wt} \%\end{array}$ & $\begin{array}{c}\mathrm{T}_{\mathrm{L}}, \\
{ }^{\circ} \mathrm{C}\end{array}$ & $\begin{array}{c}\text { Neph. } \\
\text { region }\end{array}$ & $\begin{array}{c}\mathrm{r}_{\mathrm{B}}, \\
\mathrm{g} / \mathrm{m}^{2}\end{array}$ & $\begin{array}{c}\mathrm{r}_{\mathrm{Na}}, \\
\mathrm{g} / \mathrm{m}^{2}\end{array}$ \\
\hline C106A-4 Glass & 57.22 & 848.6 & 514 & 9.35 & 9.71 & 923 & No & 0.52 & 0.19 \\
\hline Incr.WOL & 68.01 & 713.9 & 432 & 11.12 & 11.54 & 1,031 & $\mathrm{Yes}^{\mathrm{a}}$ & 0.26 & 0.06 \\
\hline Decr.WOL & 67.54 & 718.9 & 436 & 11.04 & 11.46 & 1,028 & No $^{\mathrm{a}}$ & 0.26 & 0.06 \\
\hline Red. Al 25\% & 56.45 & 823.6 & 499 & 9.64 & 7.50 & 933 & No & 0.65 & 0.36 \\
\hline Increa.WOL & 70.63 & 658.1 & 399 & 12.06 & 9.39 & 1,036 & No $^{\mathrm{a}}$ & 0.40 & 0.16 \\
\hline Red. Al 50\% & 55.82 & 796.0 & 482 & 9.97 & 5.17 & 936 & No $^{2}$ & 1.07 & 0.80 \\
\hline Incre. WOL & 75.7 & 587.0 & 356 & 13.52 & 7.01 & 1,050 & No $^{\mathrm{a}}$ & 0.64 & 0.38 \\
\hline Red. Al 75\% & 55.59 & 762.2 & 462 & 10.41 & 2.70 & 957 & No & 1.93 & 1.79 \\
\hline Inc. WOL & 65.27 & 649.2 & 393 & 12.33 & 3.17 & 986 & No & 1.63 & 1.46 \\
\hline Inc. WOL & $81.22^{\mathrm{b}}$ & 521.4 & 316 & 15.22 & 3.95 & 1,008 & No & 1.51 & 1.28 \\
\hline
\end{tabular}

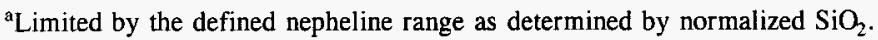

${ }^{b}$ Limited by low viscosity (3.6 Pa-S).

'Defense Waste Processing Facility canisters (1,650 kg of glass per canister).

Table 6-11 highlights the property changes that occur as the WOL and liquidus temperature are raised and $\mathrm{Al}_{2} \mathrm{O}_{3}$ and $\mathrm{Na}_{2} \mathrm{O}$ concentrations are reduced in the $\mathrm{C} 106 \mathrm{~A}-4$ glass. From these results, the optimum baseline formulation produces 436 canisters of glass based on the nepheline limit (as determined by normalized $\left.\mathrm{SiO}_{2}<0.62\right)(67.54$ percent WOL). If the durability properties of the glass are the limiting constraint (and the volume of nepheline of secondary importance), the optimum composition would be the C106A-2 glass which produces 67 fewer canisters than the base case ( 369 canisters compared to 436 canisters of glass).

The glass models also show that 37 canisters of glass could be saved by removing 25 percent of the $\mathrm{Al}_{2} \mathrm{O}_{3}$ from the waste and raising the WOL to the edge of the nepheline forming envelope ( 70.63 percent WOL). Similarly, 80 canisters could be saved if 50 percent of the $\mathrm{Al}_{2} \mathrm{O}_{3}$ inventory is removed and the WOL again raised to the edge of the nepheline forming region (75.7 percent WOL). The final step is to assume that 75 percent of the $\mathrm{Al}_{2} \mathrm{O}_{3}$ could be removed from the waste and the WOL increased from 55.59 to 81.22 percent without exceeding the nepheline, durability or liquidus temperature limits for the glass (note that $\mathrm{Fe}_{2} \mathrm{O}_{3}$ is slightly below the CVS defined limit of $15.5 \mathrm{wt} \%$ ). Under these conditions, 120 canisters of glass could be saved (in comparison to the base case formulation at 67.54 percent WOL). When the WOL is increased to 88.51 percent, the limiting conditions appear to be high $\mathrm{Fe}_{2} \mathrm{O}(16.58 \mathrm{wt} \%)$ and low $\mathrm{B}_{2} \mathrm{O}_{3}(3 \mathrm{wt} \%$, compared to the $5 \mathrm{wt} \%$ 


\section{Revision 0}

minimum in the WASRD glossary definition for borosilicate glass). Thus, by reformulating the glass to the edge of the nepheline envelope and pushing the limits of the caustic washing process, it appears that 120 total canisters could be saved, reducing repository costs for this waste by $\$ 42.7$ million, based on $\$ 356,000$ per canister. All of these savings are in reference to the base case C106A-4 glass (67.54 percent WOL). The number of canisters saved varies almost linearly with the amount of $\mathrm{Al}_{2} \mathrm{O}_{3}$ removed from the waste.

The C106A-4 glass contains $9.35 \mathrm{wt} \% \mathrm{Fe}_{2} \mathrm{O}_{3}, 0.21 \mathrm{wt} \% \mathrm{Cr}_{2} \mathrm{O}_{3}, 0.43 \mathrm{wt} \% \mathrm{MnO}$, and $9.71 \mathrm{wt} \% \mathrm{Al}_{2} \mathrm{O}_{3}$. Based on the present spinel model, the liquidus temperature will increase (or decrease) about $30^{\circ} \mathrm{C}$ for a $0.1 \mathrm{wt} \%$ increase (or decrease) in $\mathrm{Cr}_{2} \mathrm{O}_{3}, 5.2{ }^{\circ} \mathrm{C}$ for $\mathrm{MnO}$, 1.6 to $1.9^{\circ} \mathrm{C}$ for $\mathrm{Fe}_{2} \mathrm{O}_{3}$ and $0.9^{\circ} \mathrm{C}$ for $\mathrm{Al}_{2} \mathrm{O}_{3}$. The liquidus temperature is most strongly affected by $\mathrm{Cr}_{2} \mathrm{O}_{3}$, and proportionately less so by $\mathrm{MnO}, \mathrm{Fe}_{2} \mathrm{O}_{3}$, and $\mathrm{Al}_{2} \mathrm{O}_{3}$.

\subsubsection{Bounding Composition Limits for the 241-C-106B Glass.}

The water washed 241-C-106B composition is described in Table 6-1, and 241-C-106B glasses in Tables 6-3 and 6-7. The 241-C-106B composition was estimated from an archive sample of the 1986 core from Tank 241-C-106. Because of mixing problems during sample preparation, the 241-C-106B composition probably represents the upper bounding $\mathrm{Al}$ to $\mathrm{Fe}$ ratio in the waste. The optimum glass formulation appears to be the $\mathrm{C} 106 \mathrm{~B}-1$ glass $(45 \mathrm{wt} \%$ WOL). However, this glass also resides in the nepheline forming region of the $\mathrm{Na}_{2} \mathrm{O}-\mathrm{Al}_{2} \mathrm{O}_{3}$ $\mathrm{SiO}_{2}$ phase diagram. While the C106B-1 glass was found to be nepheline free after canister centerline cooling, nepheline might precipitate in this glass under more favorable conditions (slower cooling).

The glass formulation models were used to estimate the properties of the C106B-1 glass and changes induced by: (1) reducing the WOL to meet the nepheline composition limit (normalized $\mathrm{SiO}_{2}>0.62$ ), (2) reducing the amount of $\mathrm{Al}_{2} \mathrm{O}_{3}$ and $\mathrm{Na}_{2} \mathrm{O}$, and (3) increasing or decreasing the amount of $\mathrm{Fe}_{2} \mathrm{O}_{3}, \mathrm{Cr}_{2} \mathrm{O}_{3}$, and $\mathrm{MnO}$ in this waste. All glasses were formulated to a meet a target viscosity range of 4 to $6.5 \mathrm{~Pa}-\mathrm{s}$ in the melter $\left(1,150{ }^{\circ} \mathrm{C}\right)$. The liquidus temperature of the C106B- 1 glass is $986^{\circ} \mathrm{C}$, about $22^{\circ} \mathrm{C}$ below the predicted value for this glass $\left(1,008{ }^{\circ} \mathrm{C}\right)$. The results are summarized in Table 6-12, using the same nomenclature as Table 6-5, except for the defined nepheline region (which indicates whether the glass resides in the defined nepheline region as determined by the normalized $\mathrm{SiO}_{2}$ concentration). 
Table 6-12. Development of Bounding Composition Limits for the 241-C-106B Glass.

\begin{tabular}{|c|c|c|c|c|c|c|c|c|c|}
\hline Step & $\begin{array}{c}\text { WOL, } \\
\text { wt\% }\end{array}$ & $\begin{array}{c}\text { Mass, } \\
\text { MT }\end{array}$ & Cans $^{\mathrm{b}}$ & $\begin{array}{c}\mathrm{Fe}_{2} \mathrm{O}_{3}, \\
w t \%\end{array}$ & $\begin{array}{c}\mathrm{Al}_{2} \mathrm{O}_{3}, \\
\text { wt\% }\end{array}$ & $\begin{array}{c}\mathrm{T}_{\mathrm{L}}, \\
{ }^{\circ} \mathrm{C}\end{array}$ & $\begin{array}{c}\mathrm{Neph} . \\
\mathrm{Region}^{2}\end{array}$ & $\begin{array}{c}\mathrm{r}_{\mathrm{B}}, \\
\mathrm{g} / \mathrm{m}^{2}\end{array}$ & $\begin{array}{c}\mathrm{r}_{\mathrm{Na}} \\
\mathrm{g} / \mathrm{m}^{2}\end{array}$ \\
\hline C106B-1 Glass & 44.43 & 698.1 & 414 & 8.55 & 15.75 & 1,008 & Yes & 1.38 & 0.10 \\
\hline Red. WOL & 40.21 & 771.2 & 467 & 7.74 & 14.26 & 968 & $\mathrm{No}^{\mathrm{a}}$ & 0.55 & 0.07 \\
\hline Red. Al 25\% & 41.28 & 684.7 & 415 & 8.72 & 12.05 & 957 & $\mathrm{No}^{\mathrm{a}}$ & 0.91 & 0.20 \\
\hline Red. Al 50\% & 43.08 & 592.2 & 359 & 10.08 & 9.28 & 1,021 & $\mathrm{No}^{\mathrm{a}}$ & 2.0 & 0.81 \\
\hline Red. Al 75\% & 51.19 & 444.7 & 270 & 13.42 & 6.18 & 1,033 & $\mathrm{No}^{\mathrm{a}}$ & 1.78 & 1.19 \\
\hline
\end{tabular}

${ }^{a}$ Limited by the defined nepheline composition range (normalized $\mathrm{SiO}_{2}<0.62$ ).

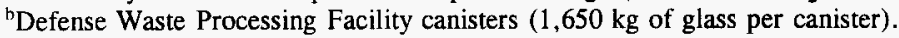

Table 6-12 summarizes the property changes that occur as the WOL is reduced to meet the nepheline composition limit and $\mathrm{Al}_{2} \mathrm{O}_{3}, \mathrm{SiO}_{2}$ and $\mathrm{Na}_{2} \mathrm{O}$ concentrations are reduced in the C106B-1 glass. From these results, it appears that 53 more canisters would be produced if the $\mathrm{C} 106 \mathrm{~B}-1$ glass is reformulated to avoid the nepheline forming region in the $\mathrm{Na}_{2} \mathrm{O}-\mathrm{Al}_{2} \mathrm{O}_{3^{-}}$ $\mathrm{SiO}_{2}$ phase diagram.

The glass models also show that this effect could be reversed if 25 percent of the $\mathrm{Al}_{2} \mathrm{O}_{3}$ is removed from the 241-C-106B waste (reducing the estimated number of canisters from 467 to 414). In this case, the final glass composition would be at the edge, but outside of the nepheline forming region. Similarly, 108 canisters of glass could be saved by reducing the amount of $\mathrm{Al}_{2} \mathrm{O}_{3}$ by 50 percent (and the number of canisters from 467 to 359). The final step is to assume that 75 percent of the $\mathrm{Al}_{2} \mathrm{O}_{3}$ could be removed, in which case 270 canisters of glass would be produced from this waste. This would save altogether 197 canisters of glass (reducing the number of such canisters from 467 to 270 ) and $\$ 70.1$ million in repository storage costs.

The C106B-1 glass contains 8.55 wt $\% \mathrm{Fe}_{2} \mathrm{O}_{3}, 0.17$ wt $\% \mathrm{Cr}_{2} \mathrm{O}_{3}, 0.47 \mathrm{wt} \% \mathrm{MnO}$, and $15.75 \mathrm{wt} \% \mathrm{Al}_{2} \mathrm{O}_{3}$. The liquidus temperature, base on current models, is projected to increase (or decrease) about $29^{\circ} \mathrm{C}$ for each increase (or decrease) of $0.1 \mathrm{wt} \%$ in $\mathrm{Cr}_{2} \mathrm{O}_{3}$, $5{ }^{\circ} \mathrm{C}$ for $\mathrm{MnO}, 1.4{ }^{\circ} \mathrm{C}$ for $\mathrm{Fe}_{2} \mathrm{O}_{3}$, and about $1{ }^{\circ} \mathrm{C}$ for $\mathrm{Al}_{2} \mathrm{O}_{3}$.

\subsubsection{Summary of Results for Phase I Experimental Glasses}

Table 6-13 provides a summary of the Phase I experimental glass properties. while Table 6-14 summarizes the glass volume estimates for these glasses. 
WHC-SD-WM-TI-768

Revision 0

Table 6-13. Properties of the Phase I Experimental Glasses.

\begin{tabular}{|c|c|c|c|c|c|c|c|}
\hline Waste & Base glass & $\begin{array}{c}\text { Base glass } \\
\text { WOL wt\% }\end{array}$ & $\begin{array}{c}\text { Base glass } \\
\text { AFO, wt\% }\end{array}$ & $\begin{array}{c}\text { Base glass, } \\
\text { canisters }\end{array}$ & $\begin{array}{c}\mathrm{T}_{\mathrm{L}} \\
\text { measured }\end{array}$ & $\begin{array}{c}\mathrm{T}_{\mathrm{L}} \\
\text { predicted }\end{array}$ & $\begin{array}{c}\text { Glass } \\
\text { formulation } \\
\text { limit }\end{array}$ \\
\hline $\begin{array}{c}\text { Water Washed } \\
\text { Nominal Blend }\end{array}$ & Nom-3 & 48.49 & 30.85 & 495 & 1,047 & 1,051 & $\mathrm{~T}_{\mathrm{L}}$ \\
\hline $\begin{array}{c}\text { Caustic Washed } \\
\text { Nominal Blend }\end{array}$ & Nomc-1 & 51.94 & 31.06 & 417 & 1,005 & 1,046 & $\begin{array}{c}\text { None @ } \\
\text { baseline } \\
\text { composition }\end{array}$ \\
\hline $\begin{array}{c}\text { Water Washed } \\
\text { AZ Blend }\end{array}$ & AZ-3 & 38.55 & 29.57 & 453 & 1,048 & 1.008 & $\begin{array}{c}\text { Nepheline } \\
\text { limit }\end{array}$ \\
\hline $\begin{array}{c}\text { Water Washed } \\
241-C-106 \mathrm{~A}\end{array}$ & $\begin{array}{c}\text { Reformulated } \\
\text { C106A-4 }\end{array}$ & 67.54 & 30.65 & 436 & -- & 1,028 & $\begin{array}{c}\text { Nepheline } \\
\text { limit }\end{array}$ \\
\hline $\begin{array}{c}\text { Water Washed } \\
241-C-106 \mathrm{~B}\end{array}$ & $\begin{array}{c}\text { Reformulated } \\
\text { C106B-1 }\end{array}$ & 40.21 & 24.86 & 467 & -- & 968 & $\begin{array}{c}\text { Nepheline } \\
\text { limit }\end{array}$ \\
\hline
\end{tabular}

AFO $=$ Adjusted feed oxide (weight of total non-volatile oxides excluding sodium and silica on one oxide basis divided by weight of the product glass.

$\mathrm{CW} \quad=$ Caustic Washed.

WW $\quad=$ Water Washed.

WOL $\quad=$ Waste oxide loading.

Nom. Blend $=$ Nominal Blend $(80$ percent Tank $241-01,80$ percent Tank 241-AZ-102, 37 percent Tank 241-C-106, 15 percent Tank 241-AY-102).

AZ Blend $=$ Tanks 241-AZ-101/241-AZ-102 Blend.

241-C-106A $=$ Based on Weiss core sample analysis of Tank 241-C-106 waste.

241-C-106B $=$ Based on Hara/McCown core sample analysis of Tank 241-C-106 waste.

Canisters $=$ Number of DWPF canisters $(1,650 \mathrm{~kg}$ of glass per canister $)$. 


\section{Revision 0}

Table 6-14. Glass Volume Estimates for Phase I Experimental Glasses.

\begin{tabular}{|c|c|c|c|c|c|c|c|}
\hline Waste & Base glass & $\begin{array}{c}\text { Base } \\
\text { glass, } \\
\text { cans. }\end{array}$ & $\begin{array}{c}\mathrm{T}_{\mathrm{L}} \text { limit @ } \\
1,100^{\circ} \mathrm{C} \\
\text { cans. }\end{array}$ & $\begin{array}{c}\text { Cans } \\
\mathbf{w} / 25 \% \\
\mathrm{Al}_{2} \mathrm{O}_{3} \\
\text { removed }\end{array}$ & $\begin{array}{c}\text { Cans } \\
\mathbf{w} / 40 \% \\
\mathrm{Al}_{2} \mathrm{O}_{3} \\
\text { removed }\end{array}$ & $\begin{array}{c}\text { Cans } \\
\mathbf{w} / 50 \% \\
\mathrm{Al}_{2} \mathrm{O}_{3} \\
\text { removed }\end{array}$ & $\begin{array}{c}\text { Cans } \\
\mathbf{w} / 75 \% \\
\mathrm{Al}_{2} \mathrm{O}_{3} \\
\text { removed }\end{array}$ \\
\hline WW Nom. Blend & Nom-3 & 495 & 442 & 478 & - & 455 & $432^{\mathrm{a}}$ \\
\hline CW Nom. Blend & Nome-1 & 417 & 384 & 411 & - & 400 & $397^{\mathbf{a}, \mathrm{b}}$ \\
\hline WW AZ Blend & AZ-3 & 453 & 394 & 430 & $421^{\mathrm{a}}$ & $\ldots=\ldots$ & - \\
\hline WW C106A & $\begin{array}{c}\text { Reform. } \\
\text { Cl06A-4 }\end{array}$ & 436 & N/A & 399 & - & 356 & 316 \\
\hline WW C106B & $\begin{array}{c}\text { Reform. } \\
\text { C106B-1 }\end{array}$ & 467 & N/A & 415 & - & 359 & $270^{\mathrm{c}}$ \\
\hline
\end{tabular}

$\begin{array}{ll}\text { WW } & =\text { Water Washed. } \\ \text { CW } & =\text { Caustic Washed }\end{array}$

Nom. Blend $=$ Nominal Blend $(80$ percent Tank $241-A Z-101,80$ percent Tank $241-A Z-102,37$ percent Tank 241-C-106, 15 percent Tank 241-AY-102).

$\mathrm{AZ}$ Blend $=$ Tank 241-AZ-101/241-AZ-102 Blend.

241-C-106A = Based on Weiss core sample analysis of Tank 241-C-106 waste.

241-C-106B = Based on Hara/McCown core sample analysis of Tank 241-C-106 waste.

Cans $\quad=$ Number of DWPF canisters $(1,650 \mathrm{~kg}$ of glass per canister).

$\mathrm{N} / \mathrm{A} \quad=$ Not applicable.

${ }^{\mathrm{a}}$ Glass limited by PCT B release.

${ }^{\mathrm{b}}$ Glass limited by $\mathrm{T}_{\mathrm{L}}$ limit $\left(@ 1,050^{\circ} \mathrm{C}\right)$.

${ }^{\circ}$ Glass limited by nepheline region.

The glass composition boundaries are typically established by the liquidus temperature or nepheline composition limits for each glass. Experimental glasses were formulated by Pacific Northwest National Laboratory. In several instances, experimental glasses were not formulated to the edge of the liquidus temperature or nepheline composition region and so these glasses were reformulated with the glass models to optimize the potential WOL for each composition. The glass models predict that 53 fewer canisters will be produced if the liquidus temperature limit is raised from 1,050 to $1,100{ }^{\circ} \mathrm{C}$ for the water washed nominal blend. Approximately 40 to 78 canisters also could be saved if caustic washing processes are used to remove 50 percent of the $\mathrm{Al}_{2} \mathrm{O}_{3}$ from nominal blend feed (the $\mathrm{CW}$ nominal blend also contains about 50 percent of the of $\mathrm{Al}_{2} \mathrm{O}_{3}$ in the nominal blend feed). The caustic washing results for the nominal blend and caustic washed nominal blend are slightly different because the glass models are non-linear and the output is often affected by the initial composition of the waste (either water or caustic washed waste). For the $\mathrm{AZ}$ blend, the minimum glass quantity was reached after removing 40 percent of the $\mathrm{Al}_{2} \mathrm{O}_{3}$ based on the durability properties of the glass as measured by PCT boron release. By removing 40 percent of the $\mathrm{Al}_{2} \mathrm{O}_{3}$, approximately 32 canisters of glass could be saved if the $\mathrm{AZ}$ blend is caustic washed. The $241-\mathrm{C}-106 \mathrm{~A}$ family of glasses will be discussed in the next section with the individual Phase I wastes. 


\section{WHC-SD-WM-TI-768 \\ Revision 0}

\subsubsection{Glass Volume Estimates for Phase I Wastes}

The glass models and glass property results were used to produce the following estimates for the water washed (base case) and caustic washed Phase I wastes (Tanks 241-AZ-101, 241-AZ-102 and 241-C-106 wastes and various blends of these wastes).

Table 6-15. Glass Volume Estimates for Unblended Phase I Wastes.

\begin{tabular}{|c|c|c|c|c|c|c|c|}
\hline $\begin{array}{c}\text { Phase I } \\
\text { Tanks }\end{array}$ & $\begin{array}{c}\text { Water } \\
\text { washed } \\
\text { waste }\end{array}$ & $\begin{array}{c}\text { Waste } \\
\text { inventory } \\
(\mathrm{MT})^{\mathbf{a}}\end{array}$ & $\begin{array}{c}\text { Base glass } \\
\text { WOL, } \\
\text { wt\% }\end{array}$ & $\begin{array}{c}\text { Base glass } \\
\mathrm{AFO}, \\
\text { Wt\% }\end{array}$ & $\begin{array}{c}\text { Cans of } \\
\text { base }^{\mathrm{b}} \text { glass } \\
\text { (limit) }\end{array}$ & $\begin{array}{c}\text { Cans w/50\% } \\
\mathrm{Al}_{2} \mathrm{O}_{3} \text { removed } \\
\text { (limit) }\end{array}$ & $\begin{array}{c}\text { Cans w/75\% } \\
\mathrm{Al}_{2} \mathrm{O}_{3} \text { removed } \\
\text { (limit) }\end{array}$ \\
\hline 241-AZ-101 & $241-\mathrm{AZ}-101$ & 109.46 & 36.08 & 30.26 & $183\left(\mathrm{~T}_{\mathrm{L}}\right)$ & $154\left(\mathrm{~T}_{\mathrm{L}}\right)$ & $145\left(\mathrm{~T}_{\mathrm{L}}\right)$ \\
\hline $241-\mathrm{AZ}-102$ & $241-\mathrm{AZ}-102$ & 172.99 & 34.40 & 29.29 & $305\left(\mathrm{~T}_{\mathrm{L}}\right)$ & $265\left(\mathrm{~T}_{\mathrm{L}}\right)$ & $268\left(\mathrm{~T}_{\mathrm{L}}\right)$ \\
\hline $241-\mathrm{C}-106$ & $241-\mathrm{C}-106 \mathrm{~A}$ & 485.52 & 67.45 & 30.65 & $436(\mathrm{Neph})$ & $356\left(\mathrm{~T}_{\mathrm{L}} / \mathrm{Neph}\right)$ & $316($ low vis $)$ \\
\hline Total & & 767.97 & & & 924 & 775 & 729 \\
\hline
\end{tabular}

${ }^{a} 100$ percent retrieval efficiency.

${ }^{b} \mathrm{DWPF}$ canisters of glass limited by $\mathrm{T}_{\mathrm{L}}$ liquidus temperature or nepheline.

Phase I Blend Compositions

Nominal Blend: $0.8 * 241-\mathrm{AZ}-101+0.8 * 241-\mathrm{AZ}-102+0.37 * 241-\mathrm{C}-106+0.15$

$$
\text { * 241-AY-102 }
$$

AZ Blend: $\quad 241-\mathrm{AZ}-101+241-\mathrm{AZ}-102$

AYC Blend: $\quad 241-\mathrm{C}-106+241-\mathrm{AY}-102$

AYC-A Blend: $241-\mathrm{AY}-102+0.1625 * 241-\mathrm{C}-106$

AYC-B Blend: $241-\mathrm{AY}-102+0.4875 * 241-\mathrm{C}-106$

AZC-A Blend: AZ Blend $+0.4875 * 241-\mathrm{C}-106$

AZC-B Blend: AZ Blend $+0.1625 * 241-\mathrm{C}-106$ 


\section{Revision 0}

Table 6-16. Glass Volume Estimates for Various Phase I Blends.

\begin{tabular}{|c|c|c|c|c|c|}
\hline $\begin{array}{l}\text { Phase I } \\
\text { blends }\end{array}$ & $\begin{array}{l}\text { Water } \\
\text { washed } \\
\text { waste }\end{array}$ & $\begin{array}{c}\text { Waste } \\
\text { inventory } \\
\text { (MT) }\end{array}$ & $\begin{array}{l}\text { Cans }^{\mathrm{a}} \text { of base } \\
\text { glass (limit) }\end{array}$ & $\begin{array}{c}\text { Cans } \mathrm{w} / 50 \% \\
\mathrm{Al}_{2} \mathrm{O}_{3} \text { removed } \\
\text { (limit) }^{\mathrm{b}}\end{array}$ & $\begin{array}{l}\text { Cans w/75\% } \\
\mathrm{Al}_{2} \mathrm{O}_{3} \\
\text { removed } \\
\text { (limit) }^{\mathrm{b}}\end{array}$ \\
\hline Nominal & Nominal & 396.3 & $495\left(\mathrm{~T}_{\mathrm{L}}\right)$ & $455\left(\mathrm{~T}_{\mathrm{L}}\right)$ & $432\left(T_{\mathrm{L}}\right)$ \\
\hline AZ Blend & AZ Blend & 282.52 & 453 (neph.) & $\begin{array}{l}421 \text { (Dur.w/40\% } \\
\mathrm{Al}_{2} \mathrm{O}_{3} \text {-removed) }\end{array}$ & $N / A$ \\
\hline $\mathrm{AYC}$ & $\begin{array}{c}241-\mathrm{AY}-102 / \\
241-\mathrm{C}-106 \mathrm{~A}\end{array}$ & 514.55 & 554 (neph.) & 397 (neph.) & $343\left(\mathrm{~T}_{\mathrm{L}}\right)$ \\
\hline AYC-A & $\mid \begin{array}{c}241-\mathrm{AY}-102 / \\
241-\mathrm{C}-106 \mathrm{~A}\end{array}$ & 116.23 & 139 (neph.) & $99\left(\mathrm{~T}_{\mathrm{L}}\right)$ & $96\left(T_{L}\right)$ \\
\hline AYC-B & $\mid \begin{array}{c}241-\mathrm{AY}-102 / \\
241-\mathrm{C}-106 \mathrm{~A}\end{array}$ & 281.36 & 333 (neph.) & 220 (neph.) & 211 (durable) \\
\hline AZC-A & $\begin{array}{c}241-\mathrm{AZ}-101 / \\
241-\mathrm{AZ}-102 / \\
241-\mathrm{C}-106 \mathrm{~A}\end{array}$ & 479.83 & 600 (neph.) & $477\left(\mathrm{~T}_{\mathrm{L}}\right)$ & $461\left(T_{L}\right)$ \\
\hline AZC-B & $\begin{array}{c}241-\mathrm{AZ}-101 / \\
241-\mathrm{AZ}-102 / \\
241-\mathrm{C}-106 \mathrm{~A}\end{array}$ & 315.14 & 450 (neph.) & $372\left(T_{L}\right)$ & $365\left(T_{L}\right)$ \\
\hline
\end{tabular}

${ }^{\mathrm{a}} \mathrm{DWPF}$ canisters of glass.

${ }^{b}$ Glass formulation limit ( $T_{L}$ liquidus temperature limit, neph. nepheline composition limit, durability limit).

If caustic washing processes are employed, the glass models indicate 80 canisters could be saved by removing 50 percent of the $\mathrm{Al}_{2} \mathrm{O}_{3}$ from Tank 241-C-106 waste and 120 canisters if 75 percent of the $\mathrm{Al}_{2} \mathrm{O}_{3}$ is removed from this waste. Caustic washing processes appear to be less desirable for Tanks 241-AZ-101 and 241-AZ-102 wastes, producing 29 and 40 fewer canisters, respectively. These estimates are based on the physical and chemical properties of the glass. Caustic washing studies will be necessary to determine whether it is possible to remove this much aluminum from the Phase I wastes. Also, it is unclear whether the TWRS safety basis could be modified in time to allow enough tank space for a caustic washing option for these wastes.

If Tanks 241-AZ-101/241-AZ-102 wastes are caustic washed, approximately 419 canisters could be produced from the residual waste (Table 6-15), compared to 421 canisters from the caustic washed AZ blend (Table 6-16). The total amount of glass derived from Tanks 241-AZ-101 and 241-AZ-102 waste (488 canisters base case) is slightly 
more than predicted for the $\mathrm{AZ}$ blend (453 canisters). Again, this is an instance where the nonlinear glass models have produced slightly different results depending on the initial composition of the waste.

Glass property data indicate the maximum waste oxide loading of the nominal blend feed is $48.5 \mathrm{wt} \%$ total oxides or $30.9 \mathrm{wt} \%$ on an adjusted feed oxide (AFO) basis. The AFO basis is defined as the weight of total non-volatile feed oxides excluding sodium and silica on an oxide basis divided by weight of the product glass. If the Phase I wastes are processed separately, the average waste oxide loading is $30.1 \mathrm{wt} \%$ AFO. This indicates that little benefit will be gained from blending in terms of reducing the overall volume of glass. However, there may be other benefits from blending, including reducing the concentration of problem components (such as silver) and reducing the number of glasses and process conditions that need to be qualified.

Current estimates do not include any allowance for operating margin contingency (to compensate for uncertainties in the waste or glass composition analysis). If it is assumed that production glasses are formulated to 85 percent of the maximum waste loading, the average waste loading for the tank by tank and nominal blend feed are 25.6 and 26.3 percent AFO, respectively. For the tank by tank feed, this results in $957,000 \mathrm{~kg}$ of glass ( 580 canisters) for the minimum Phase I feed of $245,000 \mathrm{~kg}$ OFT or $1,800,000 \mathrm{~kg}$ of glass $(1,100$ canisters) for the maximum feed of $465,000 \mathrm{~kg}$ OFT.

Based on these models and glass property data, the maximum waste loading for the Phase I glasses varies from 29.76 to $30.65 \mathrm{wt} \%$ on an adjusted feed oxide basis. This indicates there is a 17 percent contingency or operating margin between the maximum theoretical waste loading and the minimum 25 percent adjusted feed oxide basis specified in the RFP. The 25 percent AFO appears to be conservative and an achievable value for Phase I.

\subsubsection{Bounding Effects of $\mathrm{Al}_{2} \mathrm{O}_{3}$ and $\mathrm{Fe}_{2} \mathrm{O}_{3}$ in Glass}

Sensitivity analyses were also performed to evaluate the effects of feed composition and more aggressive caustic washing processes for these wastes. The purposes of this analysis is to provide feedback to the pretreatment and waste retrieval functions, and to identify high priority issues to be addressed in any future waste characterization activities.

The most important components from a glass making perspective are $\mathrm{Al}_{2} \mathrm{O}_{3}$ and $\mathrm{Fe}_{2} \mathrm{O}_{3}$. Because glass volume predictions are important to overall project cost, a sensitivity study was performed to assess the likely impact of varying the amount of $\mathrm{Al}_{2} \mathrm{O}_{3}$ and $\mathrm{Fe}_{2} \mathrm{O}_{3}$ in the Tanks 241-AZ-101 and 241-C-106 wastes. Two glasses were chosen for this investigation, including high waste loaded glasses developed from Tanks 241-AZ-101 and 241-C-106 wastes, which represent the bulk of the Phase I wastes. In this study, glass composition boundaries were systematically investigated by varying the amount of $\mathrm{Al}_{2} \mathrm{O}_{3}$ and $\mathrm{Fe}_{2} \mathrm{O}_{3}$ in the 
waste from -75 to +100 percent of the nominal inventory and formulating the optimum glasses for each composition.

The results are summarized in Tables 6-17 and 6-18, and in Figures 6-1 through 6-8 for Tank 241-AZ-101 waste. Figure 6-1 shows the effect of varying the amount of $\mathrm{Al}_{2} \mathrm{O}_{3}$ in Tank AZ-101 based on three different glass formulation constraints. The CVS single component glass limits represent the bounding compositions used in the CVS glass formulation study ( $15 \mathrm{wt} \% \mathrm{Fe}_{2} \mathrm{O}_{3}$ and $17 \mathrm{wt} \% \mathrm{Al}_{2} \mathrm{O}_{3}$ ), while the liquidus temperature and nepheline limits represent the glass property limits for avoiding sludge accumulation problems in the melter and for meeting acceptable durability conditions at the canister centerline, respectively. Other properties such as viscosity and durability as measured by boron and sodium release are also important, but only rarely become the limiting constraints for glass formulation. In Figure 6-2, glass model predictions and CVS single component glass limits are presented as a function of the amount of $\mathrm{Al}_{2} \mathrm{O}_{3}$ in Tank 241-AZ-101 waste. Glass model predictions are based on the minimum volume of glass consistent with the liquidus temperature and nepheline limits.

In the region from -75 to 0 percent change in the nominal $\mathrm{Al}_{2} \mathrm{O}_{3}$ inventory, the liquidus temperature limit controls the volume of glass, while the nepheline limit controls the composition of the glass from 0 to 100 percent increase in the nominal $\mathrm{Al}_{2} \mathrm{O}_{3}$ inventory. The CVS single component glass limits tend to be overly optimistic with respect to glass model predictions for this waste. Based on the results in Table 7-4, the CVS single component limits tend to underpredict the actual amount of glass by 30 to 60 percent in the high $\mathrm{Al}_{2} \mathrm{O}_{3}$ range and 5 to 30 percent in the lower $\mathrm{Al}_{2} \mathrm{O}_{3}$ (and higher $\mathrm{Fe}_{2} \mathrm{O}_{3}$ ) concentration range. If CVS multi-component limits were also used $\left(\mathrm{Fe}_{2} \mathrm{O}_{3}+\mathrm{Al}_{2} \mathrm{O}_{3}+\mathrm{ZrO}_{2}+\right.$ others $\left.\leq 0.24\right)$, glass volume estimates would be closer to glass model predictions for this waste.

Table 6-17. Glass Volume as a Function of the Amount of $\mathrm{Al}_{2} \mathrm{O}_{3}$ in Tank 241-AZ-101 Waste.

\begin{tabular}{|c|c|c|c|c|c|c|c|}
\hline $\begin{array}{c}\mathrm{Al}_{2} \mathrm{O}_{3}, \\
\text { in mange } \\
\text { in mass }\end{array}$ & $\begin{array}{c}\mathrm{HLW} \\
\text { glass } \\
\text { model, } \\
\text { cans }\end{array}$ & $\begin{array}{c}\text { CVS glass } \\
\text { limits, } \\
\text { cans } \\
\text { (limit) }\end{array}$ & $\begin{array}{c}\text { Liq. } \\
\text { temp. } \\
\text { limit, } \\
\text { cans }\end{array}$ & $\begin{array}{c}\text { Neph. } \\
\text { limit, } \\
\text { cans }\end{array}$ & $\begin{array}{c}\mathrm{Al}_{2} \mathrm{O}_{3} \\
\text { conc. in } \\
\text { glass, } \\
\text { wt \% }\end{array}$ & $\begin{array}{c}\mathrm{Fe}_{2} \mathrm{O}_{3} \\
\text { conc. in } \\
\text { glass, } \\
\text { wt\% }\end{array}$ & $\begin{array}{c}\text { Glass } \\
\text { vol\% } \\
\text { change }\end{array}$ \\
\hline-75 & 145 & $139(\mathrm{Fe})$ & 145 & 136 & 2.64 & 14.4 & -20.8 \\
\hline-50 & 154 & $139(\mathrm{Fe})$ & 154 & 150 & 4.97 & 13.54 & -15.8 \\
\hline 0 & 183 & $139(\mathrm{Fe})$ & 183 & 182 & 8.35 & 11.38 & 0 \\
\hline 25 & 211 & $139(\mathrm{Fe})$ & 189 & 211 & 9.08 & 9.9 & 15.3 \\
\hline 50 & 238 & $139(\mathrm{Fe})$ & 204 & 238 & 9.67 & 8.78 & 30.0 \\
\hline 75 & 270 & $158(\mathrm{Al})$ & 219 & 270 & 9.95 & 7.75 & 47.5 \\
\hline 100 & 286 & $180(\mathrm{Al})$ & 229 & 286 & 10.71 & 7.30 & 56.3 \\
\hline
\end{tabular}

${ }^{\mathrm{a}}$ Glass composition based on the minimum volume of glass consistent with the liquidus temperature and nepheline limits (i.e., high-level waste glass model predictions). 


\section{Revision 0}

Table 6-18. Glass Volume as a Function of the Amount of $\mathrm{Fe}_{2} \mathrm{O}_{3}$ in Tank 241-AZ-101 Waste.

\begin{tabular}{|c|c|c|c|c|c|c|c|}
\hline $\begin{array}{c}\mathrm{Fe}_{2} \mathrm{O}_{3}, \% \\
\text { change in } \\
\text { mass }\end{array}$ & $\begin{array}{c}\mathrm{HLW} \\
\text { glass } \\
\text { models, } \\
\text { cans }\end{array}$ & $\begin{array}{c}\text { CVS glass } \\
\text { limits, } \\
\text { cans }\end{array}$ & $\begin{array}{c}\text { Liq. } \\
\text { temp. } \\
\text { limit, } \\
\text { cans }\end{array}$ & $\begin{array}{c}\text { Neph. } \\
\text { limit, } \\
\text { cans }\end{array}$ & $\begin{array}{c}\mathrm{Al}_{2} \mathrm{O}_{3} \\
\text { conc..in } \\
\text { glass, } \\
\text { wt\% }\end{array}$ & $\begin{array}{c}\mathrm{Fe}_{2} \mathrm{O}_{3} \\
\text { conc. in } \\
\text { glass, } \\
\text { wt \% }\end{array}$ & $\begin{array}{c}\text { Glass } \\
\text { vol\% } \\
\text { change }\end{array}$ \\
\hline-75 & 174 & $90(\mathrm{Al})$ & 137 & 174 & 8.8 & 3.0 & -4.9 \\
\hline-50 & 176 & $90(\mathrm{Al})$ & 147 & 176 & 8.63 & 5.88 & -3.8 \\
\hline-25 & 180 & $104(\mathrm{Fe})$ & 161 & 180 & 8.50 & 8.68 & -1.6 \\
\hline 0 & 183 & $139(\mathrm{Fe})$ & 183 & 182 & 8.35 & 11.38 & 0 \\
\hline 25 & 202 & $174(\mathrm{Fe})$ & 202 & 196 & 7.60 & 12.95 & 10.4 \\
\hline 50 & 224 & $209(\mathrm{Fe})$ & 224 & 210 & 6.84 & 13.99 & 23.4 \\
\hline 75 & 241 & $244(\mathrm{Fe})$ & 241 & 232 & 6.36 & 15.16 & 31.7 \\
\hline 100 & 261 & $278(\mathrm{Fe})$ & 261 & 250 & 5.86 & 15.98 & 42.7 \\
\hline
\end{tabular}

${ }^{a}$ Glass composition based on the minimum volume of glass consistent with the liquidus temperature and nepheline limits (i.e., high-level waste glass model predictions). 


\section{Revision 0}

Figure 6-1. Effect of Liquidus Temperature, Nepheline, and Composition Variability Study Limits on Volume of Glass versus $\mathrm{Al}_{2} \mathrm{O}_{3}$ in Tank 241-AZ-101 Waste.

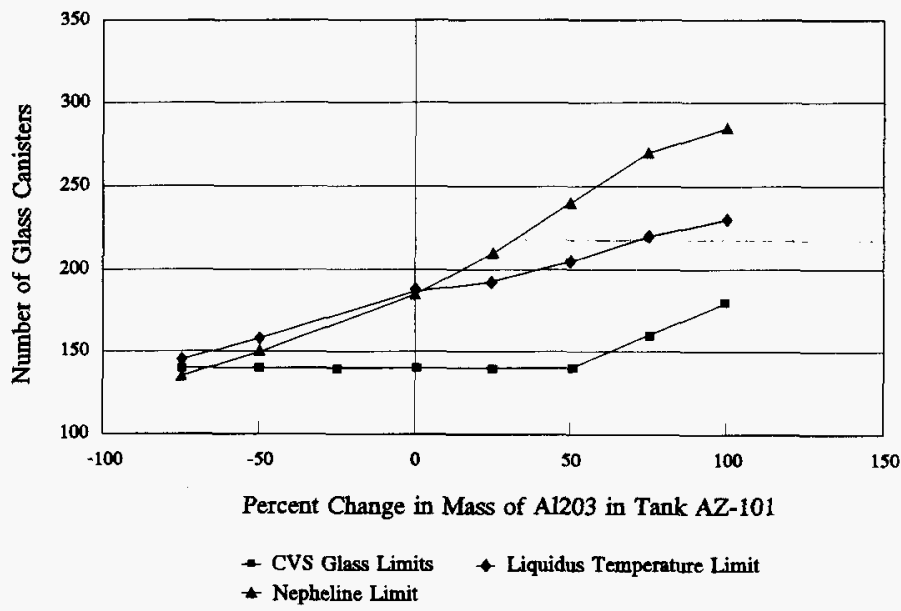

Figure 6-2. Effect of High-Level Waste Glass Model and Composition Variability Study Limits on Volume of Glass versus $\mathrm{Al}_{2} \mathrm{O}_{3}$ in Tank 241-AZ-101 Waste.

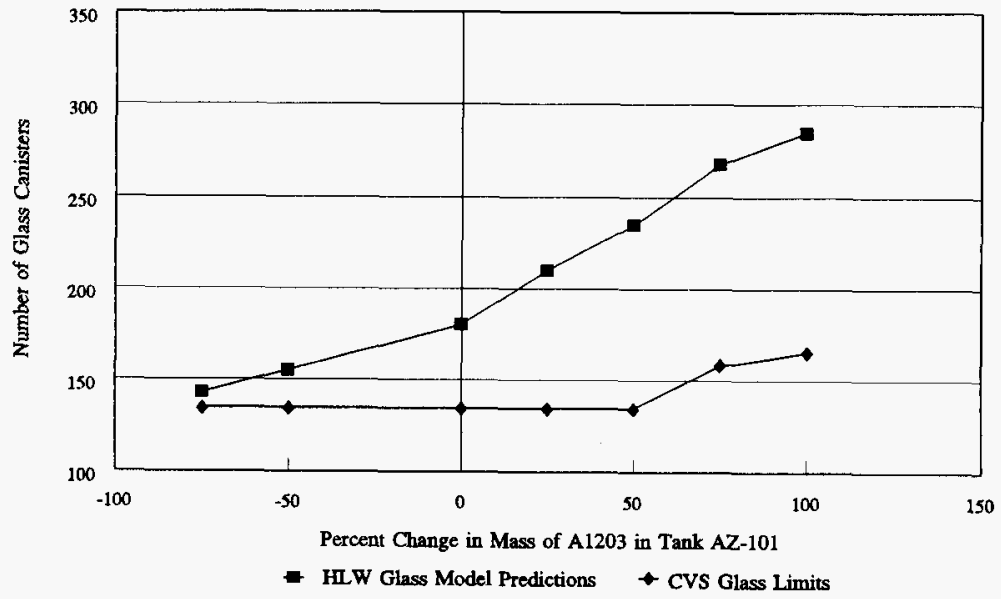


WHC-SD-WM-TI-768

Revision 0

Figure 6-3. $\mathrm{Al}_{2} \mathrm{O}_{3}$ and $\mathrm{Fe}_{2} \mathrm{O}_{3}$ Concentrations in Glass versus $\mathrm{Al}_{2} \mathrm{O}_{3}$ in Tank 241-AZ-101.

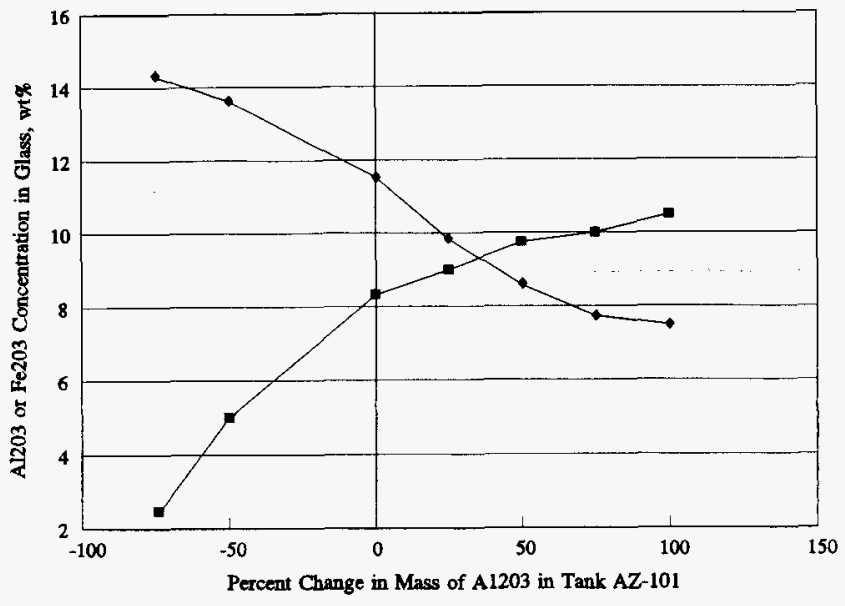

- A1203 Concentration in Gless, wr\% + Fe203 Concentration in Glass, wt\%

Figure 6-4. Change in Volume of Glass versus Percent Change of $\mathrm{Al}_{2} \mathrm{O}_{3}$ in Tank 241-AZ-101 Waste.

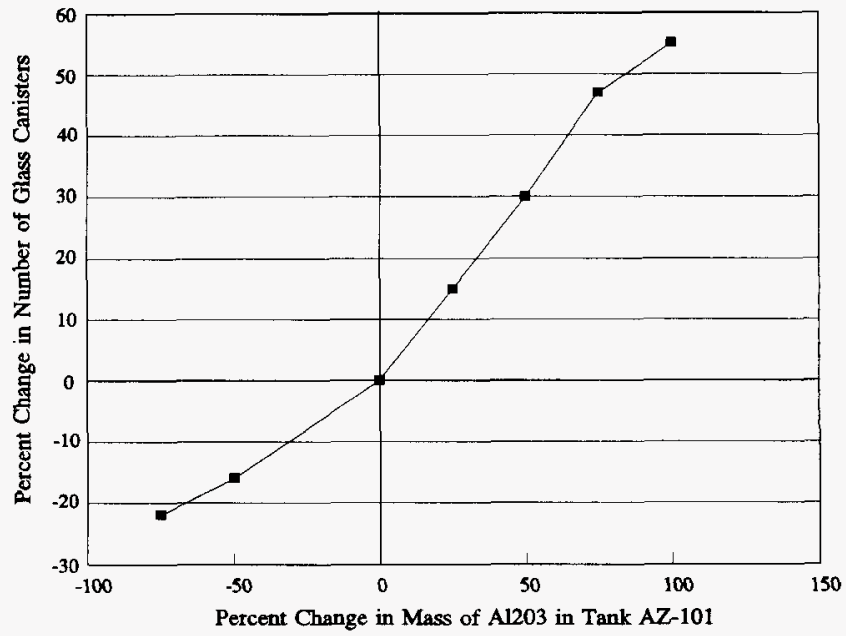




\section{WHC-SD-WM-TI-768}

\section{Revision 0}

Figure 6-5. Effect of Liquidus Temperature, Nepheline, and Composition Variability Study Limits on Volume of Glass versus $\mathrm{Fe}_{2} \mathrm{O}_{3}$ in Tank 241-AZ-101 Waste.

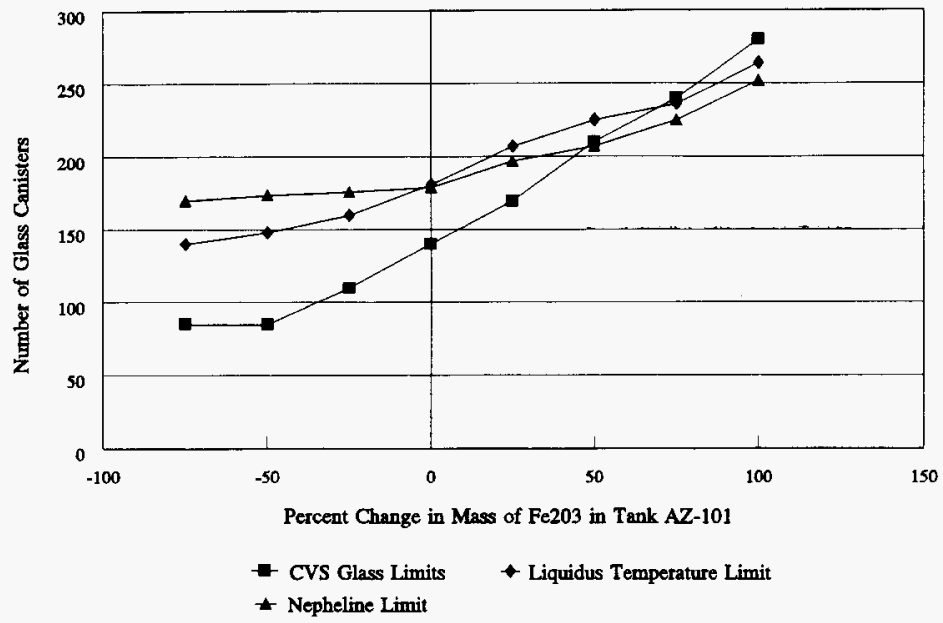

Figure 6-6. Effect of High-Level Waste Glass Model and Composition Variability Study Limits on Volume of Glass versus $\mathrm{Fe}_{2} \mathrm{O}_{3}$ in Tank 241-AZ-101 Waste.

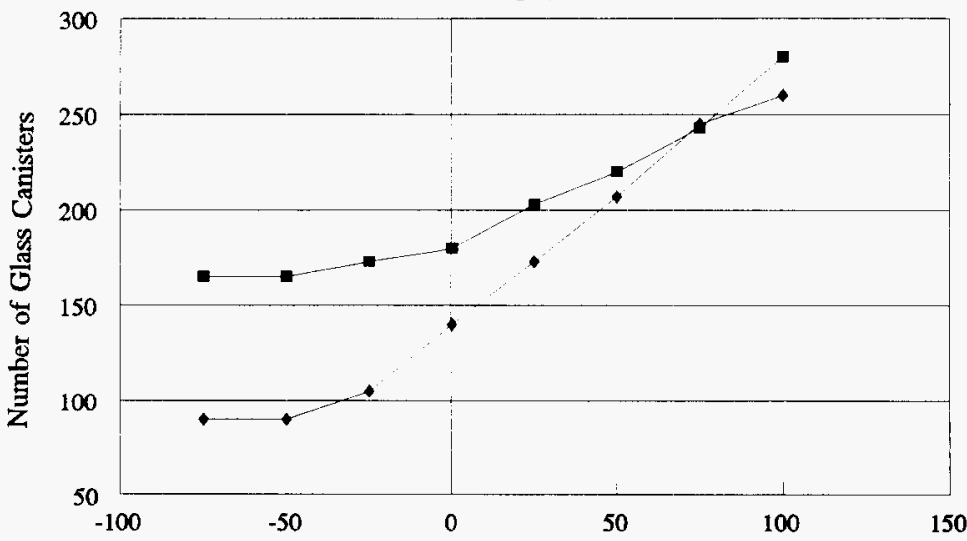

Petcent Change in Mass of Fe203 in Tank AZ-101

-HLW Glass Model Predictions $\rightarrow$ CVS Glass Limits 
WHC-SD-WM-TI-768

Revision 0

Figure 6-7. $\mathrm{Fe}_{2} \mathrm{O}_{3}$ and $\mathrm{Al}_{2} \mathrm{O}_{3}$ Concentrations in Glass versus $\mathrm{Fe}_{2} \mathrm{O}_{3}$ in Tank 241-AZ-101 Waste.

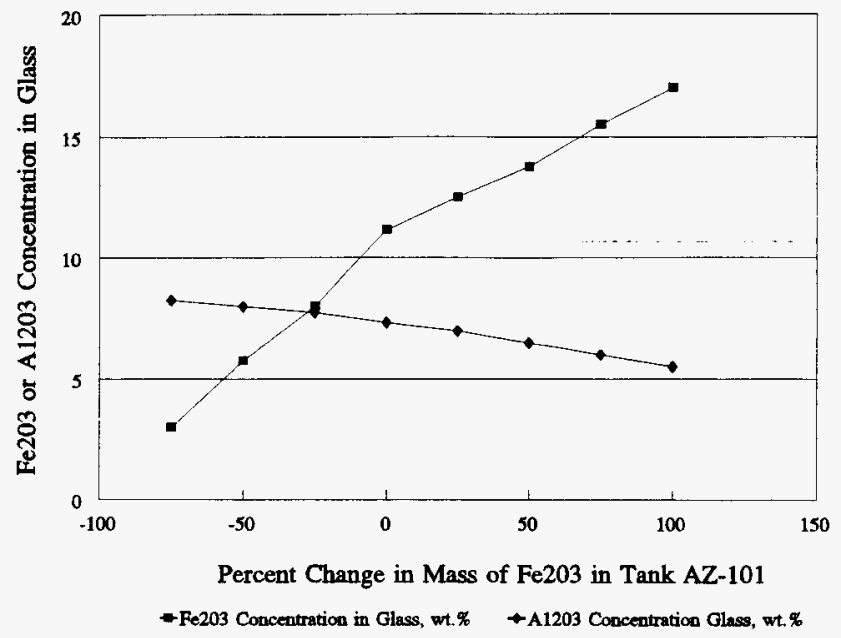

Figure 6-8. Change in Volume of Glass versus Percent Change of $\mathrm{Fe}_{2} \mathrm{O}_{3}$ in Tank 241-AZ-101 Waste.

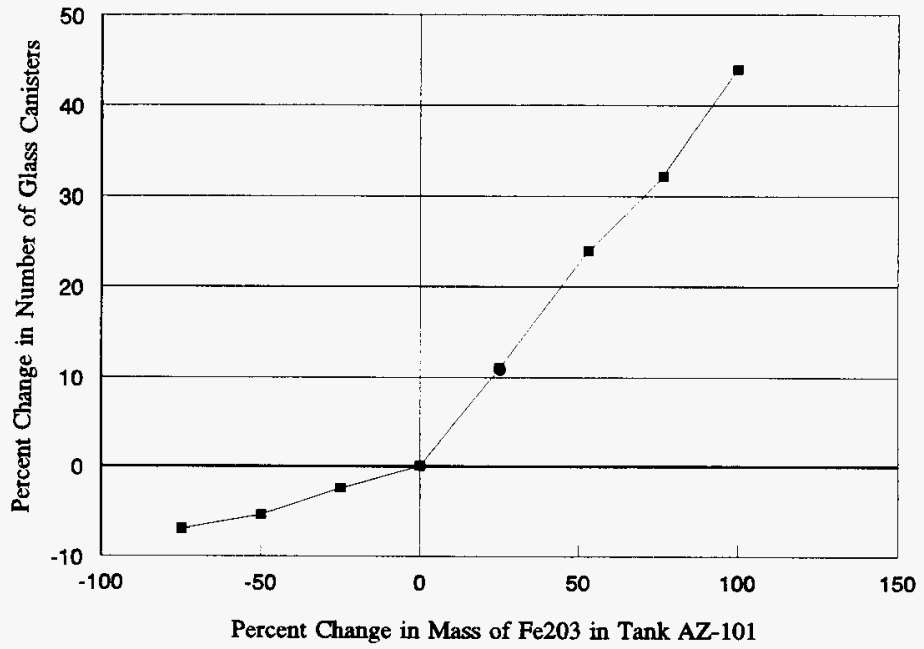


The $\mathrm{Al}_{2} \mathrm{O}_{3}$ and $\mathrm{Fe}_{2} \mathrm{O}_{3}$ glass compositions are shown as a function of the Tank 241-AZ-101 $\mathrm{Al}_{2} \mathrm{O}_{3}$ inventory in Figure 6-3. Tank 241-AZ-101 glass limits change from nepheline to liquidus temperature control at the base case glass composition (8.35 wt $\mathrm{Al}_{2} \mathrm{O}_{3}$ and $11.38 \mathrm{wt} \% \mathrm{Fe}_{2} \mathrm{O}_{3}$ ). This transition is important because it shows that nepheline is the limiting property above the $\mathrm{Al}_{2} \mathrm{O}_{3}$ to $\mathrm{Fe}_{2} \mathrm{O}_{3}$ ratio of 0.74 in the glass (and Tank 241-AZ-101 waste), while liquidus temperature is the limiting property below this ratio. Figure 6-4 shows the relative change in the number of canisters as a function of the amount of $\mathrm{Al}_{2} \mathrm{O}_{3}$ in Tank 241-AZ-101. The overall glass volume increases 56 percent with a 100 percent increase in the amount of $\mathrm{Al}_{2} \mathrm{O}_{3}$ in this waste, but decreases only 21 percent with a 75 percent decrease of $\mathrm{Al}_{2} \mathrm{O}_{3}$. Under nepheline control, the glass-volume increases strongly with the amount of $\mathrm{Al}_{2} \mathrm{O}_{3}$ in the waste, while the volume decreases only about one-half as much under liquidus temperature control. Therefore, caustic washing appears to be only about 50 percent effective (in terms of glass volume reduction) in the liquidus temperature (or iron solubility controlled) region of the composition envelope (below the $\mathrm{Al}_{2} \mathrm{O}_{3}$ to $\mathrm{Fe}_{2} \mathrm{O}_{3}$ ratio of 0.74 for Tank 241-AZ-101 waste).

Figures 6-5 through 6-8 show the reverse effect of varying the $\mathrm{Fe}_{2} \mathrm{O}_{3}$ content of Tank 241-AZ-101 waste. The CVS single component, liquidus temperature, and nepheline limits are shown as a function of the amount of $\mathrm{Fe}_{2} \mathrm{O}_{3}$ in the waste in Figure 6-5. Once again, the CVS single component limits are overly conservative (tend to underpredict the volume of glass) in the low $\mathrm{Fe}_{2} \mathrm{O}_{3}$ (and high $\mathrm{Al}_{2} \mathrm{O}_{3}$ ) range, but are in better agreement with the glass models in the high $\mathrm{Fe}_{2} \mathrm{O}_{3}$ range ( 150 to 200 percent of the baseline inventory). The baseline composition serves as the dividing point between the nepheline and liquidus temperature control (with the liquidus temperature control region being located to the right or in the high $\mathrm{Fe}_{2} \mathrm{O}_{3}$ glass composition region). The HLW glass model predictions and CVS single component glass limits are presented as a function of $\mathrm{Fe}_{2} \mathrm{O}_{3}$ composition in Figure 6-6. Glass predictions are based on the minimum volume of glass consistent with the nepheline and liquidus temperature limits. In this case, the CVS single component glass limits tend to underpredict the volume of glass by 30 to 60 percent in the low $\mathrm{Fe}_{2} \mathrm{O}_{3}$ region, and more closely agree with the glass models and actually overpredict the amount of glass by 6.5 percent at the extreme end of the $\mathrm{Fe}_{2} \mathrm{O}_{3}$ composition envelope (200 percent of the baseline inventory).

The predicted $\mathrm{Fe}_{2} \mathrm{O}_{3}$ and $\mathrm{Al}_{2} \mathrm{O}_{3}$ concentrations in glass are shown as a function of the Tank 241-AZ-101 $\mathrm{Fe}_{2} \mathrm{O}_{3}$ inventory in Figure 6-7. The transition between nepheline and liquidus temperature control once again occurs at the baseline glass composition $(8.35 \mathrm{wt} \%$ $\mathrm{Al}_{2} \mathrm{O}_{3}$ and $11.38 \mathrm{wt} \% \mathrm{Fe}_{2} \mathrm{O}_{3}$ ), with the nepheline region being to the left of the baseline composition and the liquidus temperature controlled region to the right. In Figure 6-8, the relative glass volume is shown as a function of Tank 241-AZ-101 $\mathrm{Fe}_{2} \mathrm{O}_{3}$ concentration. According to current models, the glass volume increases 43 percent with a 100 percent increase in the amount of $\mathrm{Fe}_{2} \mathrm{O}_{3}$ in this waste, but only decreases 4.9 percent with a 75 percent decrease of $\mathrm{Fe}_{2} \mathrm{O}_{3}$. Under liquidus temperature control, the glass volume increases strongly with the amount of $\mathrm{Fe}_{2} \mathrm{O}_{3}$ in the waste, but decreases only slightly with a diminishing amount of $\mathrm{Fe}_{2} \mathrm{O}_{3}$ under nepheline composition control. If the mass of all components except $\mathrm{Al}_{2} \mathrm{O}_{3}$ or $\mathrm{Fe}_{2} \mathrm{O}_{3}$ is held constant, the volume of Tank 241-AZ-101 glass is 
projected to increase 4.3 and 5.6 percent with a 10 percent increase in the amount of $\mathrm{Fe}_{2} \mathrm{O}_{3}$ or $\mathrm{Al}_{2} \mathrm{O}_{3}$, respectively, and decrease 0.65 and 2.8 percent with a decrease of 10 percent in the amount of $\mathrm{Fe}_{2} \mathrm{O}_{3}$ or $\mathrm{Al}_{2} \mathrm{O}_{3}$ in this waste. These figures can be used to estimate the cost of over-estimating or under-estimating the mass of these components (based on a repository disposal fee of $\$ 356,000$ per canister). These results simulate the effect of reducing $\mathrm{Al}_{2} \mathrm{O}_{3}$ by using the caustic washing process or inadvertently adding $\mathrm{Al}_{2} \mathrm{O}_{3}$ by precipitation from the liquid phase.

The glass modelling results for Tank 241-C-106 waste are summarized in Tables 6-19 and 6-20, and in Figures 6-9 through 6-16. Figure 6-9 shows.the.effect of varying the amount of $\mathrm{Al}_{2} \mathrm{O}_{3}$ in Tank 241-C-106 based on the CVS single component glass, liquidus temperature and nepheline limits for HLW glass. In Figure 6-10, the HLW glass volume and CVS single component glass limits are shown as a function of the amount of $\mathrm{Al}_{2} \mathrm{O}_{3}$ in Tank 241-C-106. Glass model predictions are based on the minimum volume of glass consistent with the liquidus temperature and nepheline limits for this glass. The nepheline and liquidus temperature limits evidently converge in the range from -25 to -50 percent of the nominal $\mathrm{Al}_{2} \mathrm{O}_{3}$ inventory, while low viscosity is the limiting constraint at -75 percent $\mathrm{Al}_{2} \mathrm{O}_{3}$. The nepheline forming characteristics of the glass control the formulation results in the range from 0 to 100 percent increase in the nominal $\mathrm{Al}_{2} \mathrm{O}_{3}$ inventory. CVS single component glass limits once again tend to underpredict the actual amount of glass by 25 to 35 percent in the range from -25 to +50 percent of the baseline $\mathrm{Al}_{2} \mathrm{O}_{3}$ inventory.

Glass $\mathrm{Al}_{2} \mathrm{O}_{3}$ and $\mathrm{Fe}_{2} \mathrm{O}_{3}$ concentrations are shown as a function of $\mathrm{Al}_{2} \mathrm{O}_{3}$ inventory in Figure 6-11. The crossover from nepheline to liquidus temperature/nepheline control occurs at -25 percent of the nominal $\mathrm{Al}_{2} \mathrm{O}_{3}$ inventory $\left(9.39 \mathrm{wt} \% \mathrm{Al}_{2} \mathrm{O}_{3}\right.$ and $12.06 \mathrm{wt} \% \mathrm{Fe}_{2} \mathrm{O}_{3}$ or $\mathrm{Al}_{2} \mathrm{O}_{3}$ to $\mathrm{Fe}_{2} \mathrm{O}_{3}$ ratio of 0.77 ). This transition is interesting because it occurs in the same composition region as the (nepheline to liquidus) transition in Tank 241-AZ-101 glasses. In Figure 6-12, the relative glass volume is depicted as a function of tank C-106 $\mathrm{Al}_{2} \mathrm{O}_{3}$ composition. The glass volume increases nearly 47 percent with a 100 percent increase in the amount of $\mathrm{Al}_{2} \mathrm{O}_{3}$ in the waste, and decrease 18.3 percent with a 50 percent decrease of $\mathrm{Al}_{2} \mathrm{O}_{3}$. Under nepheline control, the volume of glass increases sharply with the amount of $\mathrm{Al}_{2} \mathrm{O}_{3}$ in the waste, and decreases at a slightly smaller rate as the amount of $\mathrm{Al}_{2} \mathrm{O}_{3}$ is reduced in the waste. 


\section{Revision 0}

Table 6-19. Glass Volume as a Function of the Amount of $\mathrm{Al}_{2} \mathrm{O}_{3}$ in Tank $\mathrm{C}-106$ Waste.

\begin{tabular}{|c|c|c|c|c|c|c|c|}
\hline $\begin{array}{c}\mathrm{Al}_{2} \mathrm{O}_{3}, \\
\% \text { change } \\
\text { in mass }\end{array}$ & $\begin{array}{c}\mathrm{HLW} \text { glass } \\
\text { models, } \\
\text { cans }\end{array}$ & $\begin{array}{c}\text { CVS glass } \\
\text { limits, cans } \\
\text { (limit) }\end{array}$ & $\begin{array}{c}\text { Liq. temp. } \\
\text { limit, cans }\end{array}$ & $\begin{array}{c}\text { Neph. } \\
\text { limit, } \\
\text { cans }\end{array}$ & $\begin{array}{c}\mathrm{Al}_{2} \mathrm{O}_{3} \\
\text { conc. in } \\
\text { glass, } \\
\text { wt. \% }\end{array}$ & $\begin{array}{c}\mathrm{Fe}_{2} \mathrm{O}_{3} \\
\text { conc. in } \\
\text { glass, } \\
\text { wt. \% }\end{array}$ & $\begin{array}{c}\text { Glass } \\
\text { vol\% } \\
\text { change }^{c}\end{array}$ \\
\hline-75 & $316^{\mathrm{a}}$ & $321(\mathrm{Fe})$ & $\mathrm{b}$ & $\mathrm{b}$ & 3.95 & 15.22 & -27.5 \\
\hline-50 & 356 & $321(\mathrm{Fe})$ & 356 & 356 & 7.01 & 13.52 & -18.35 \\
\hline-25 & 399 & $321(\mathrm{Fe})$ & 400 & 399 & -9.39 & -12.06 & -8.49 \\
\hline 0 & 436 & $321(\mathrm{Fe})$ & 419 & 436 & 11.45 & 11.03 & 0 \\
\hline 25 & 496 & $367(\mathrm{Al})$ & 480 & 496 & 12.59 & 9.7 & 13.76 \\
\hline 50 & 546 & $440(\mathrm{Al})$ & 506 & 546 & 13.73 & 8.82 & 25.23 \\
\hline 75 & 590 & $514(\mathrm{Al})$ & 558 & 590 & 14.81 & 8.16 & 35.32 \\
\hline 100 & 640 & $587(\mathrm{Al})$ & 621 & 640 & 15.59 & 7.51 & 46.79 \\
\hline
\end{tabular}

${ }^{\mathrm{a}} \mathrm{Glass}$ composition limited by low viscosity

${ }^{b}$ Liquidus temperature could not be increased to target level without adding $\mathrm{Al}_{2} \mathrm{O}_{3}$.

${ }^{c}$ Glass composition based on the minimum volume of glass consistent with the liquidus temperature and nepheline limits (i.e., high-level waste glass model predictions).

Table 6-20. Glass Volume as a Function of the Amount of $\mathrm{Fe}_{2} \mathrm{O}_{3}$ in Tank 241-C-106 Waste.

\begin{tabular}{|c|c|c|c|c|c|c|c|}
\hline $\begin{array}{c}\mathrm{Fe}_{2} \mathrm{O}_{3}, \% \\
\text { change in } \\
\text { mass }\end{array}$ & $\begin{array}{c}\text { HLW glass } \\
\text { models, } \\
\text { cans }\end{array}$ & $\begin{array}{c}\text { CVS glass } \\
\text { limits, cans } \\
\text { (limit) }\end{array}$ & $\begin{array}{c}\text { Liq. temp. } \\
\text { limit, cans }\end{array}$ & $\begin{array}{c}\text { Neph. } \\
\text { limit, } \\
\text { cans }\end{array}$ & $\begin{array}{c}\mathrm{Al}_{2} \mathrm{O}_{3} \\
\text { conc. in } \\
\text { glass, } \\
\text { wt. }\end{array}$ & $\begin{array}{c}\mathrm{Fe}_{2} \mathrm{O}_{3} \\
\text { conc. in } \\
\text { glass, } \\
\text { wt. \% }\end{array}$ & $\begin{array}{c}\text { Glass } \\
\text { vol\% } \\
\text { change }\end{array}$ \\
\hline-75 & 402 & $294(\mathrm{Al})$ & 390 & 402 & 12.43 & 2.99 & -7.80 \\
\hline-50 & 409 & $294(\mathrm{Al})$ & 395 & 409 & 12.21 & 5.88 & -6.19 \\
\hline-25 & 418 & $294(\mathrm{Al})$ & 404 & 418 & 11.95 & 8.63 & -4.13 \\
\hline 0 & 436 & $321(\mathrm{Fe})$ & 419 & 436 & 11.45 & 11.03 & 0 \\
\hline 25 & 451 & $401(\mathrm{Fe})$ & 451 & 442 & 11.08 & 13.34 & 1.38 \\
\hline 50 & 497 & $481(\mathrm{Fe})$ & 497 & 450 & 10.04 & 14.52 & 13.99 \\
\hline 75 & 575 & $561(\mathrm{Fe})$ & 575 & 480 & 8.68 & 14.64 & 31.88 \\
\hline 100 & 624 & $642(\mathrm{Fe})$ & 624 & 480 & 8.0 & 15.42 & 43.10 \\
\hline
\end{tabular}

${ }^{\mathrm{a}}$ Glass composition based on the minimum volume of glass consistent with the liquidus temperature and nepheline limits (i.e., high-level waste glass model predictions). 


\section{WHC-SD-WM-TI-768}

\section{Revision 0}

Figure 6-9. Effect of Liquidus Temperature, Nepheline, and Composition Variability Study Limits on Volume of Glass versus $\mathrm{Al}_{2} \mathrm{O}_{3}$ in Tank 241-C-106 Waste.

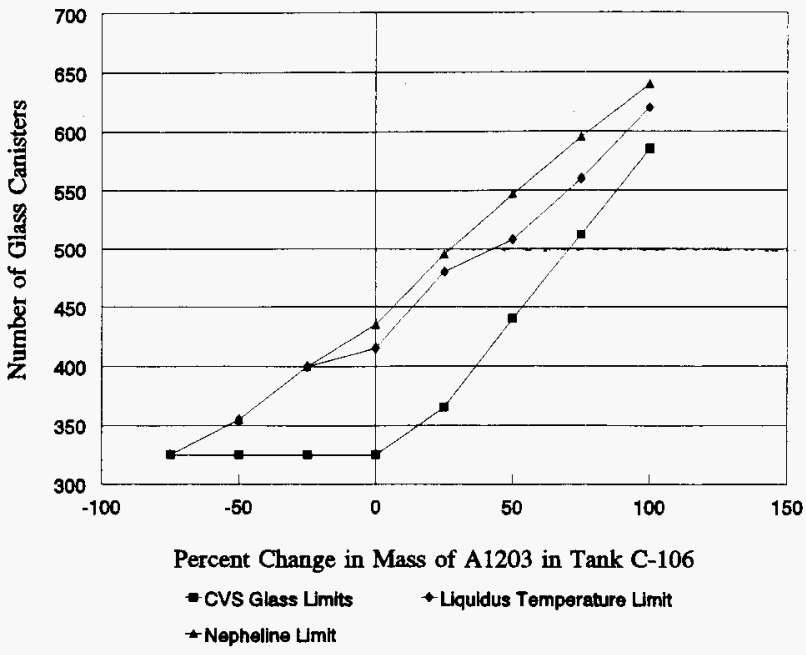

Figure 6-10. Effect of High-Level Waste Glass Model and Composition Variability Study Limits on Volume of Glass versus $\mathrm{Al}_{2} \mathrm{O}_{3}$ in Tank 241-C-106 Waste.

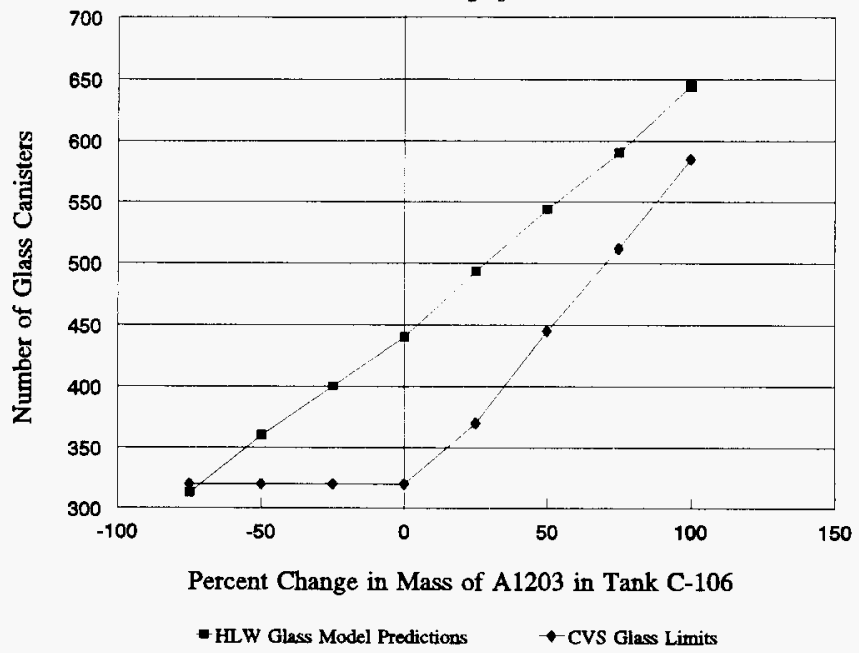




\section{WHC-SD-WM-TI-768}

Revision 0

Figure 6-11. $\mathrm{Al}_{2} \mathrm{O}_{3}$ and $\mathrm{Fe}_{2} \mathrm{O}_{3}$ Concentrations in Glass versus $\mathrm{Al}_{2} \mathrm{O}_{3}$ in Tank 241-C-106 Waste.

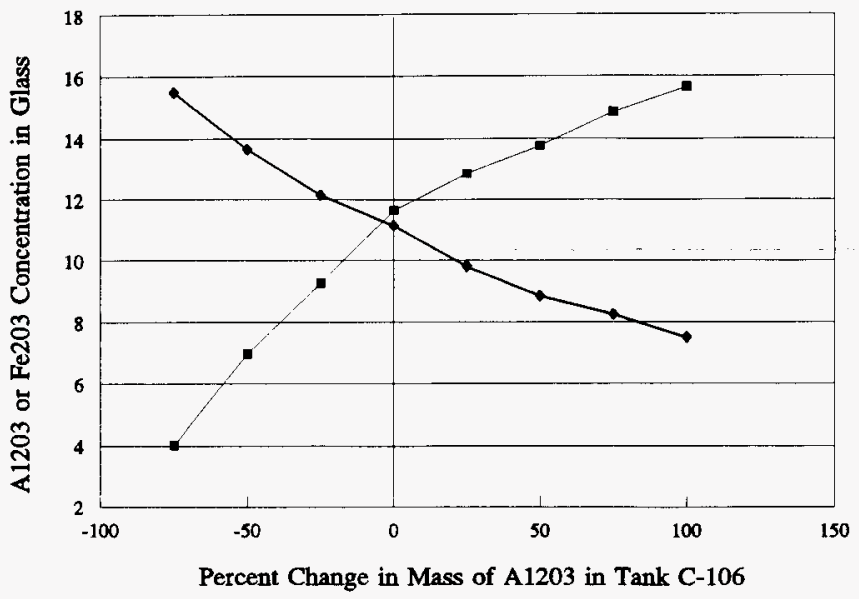

- A1203 Concentration in Glass $\leftarrow$ Fe203 Concentration in Glass

Figure 6-12. Change in Volume of Glass versus Percent Change of $\mathrm{Al}_{2} \mathrm{O}_{3}$ in Tank 241-C-106 Waste.

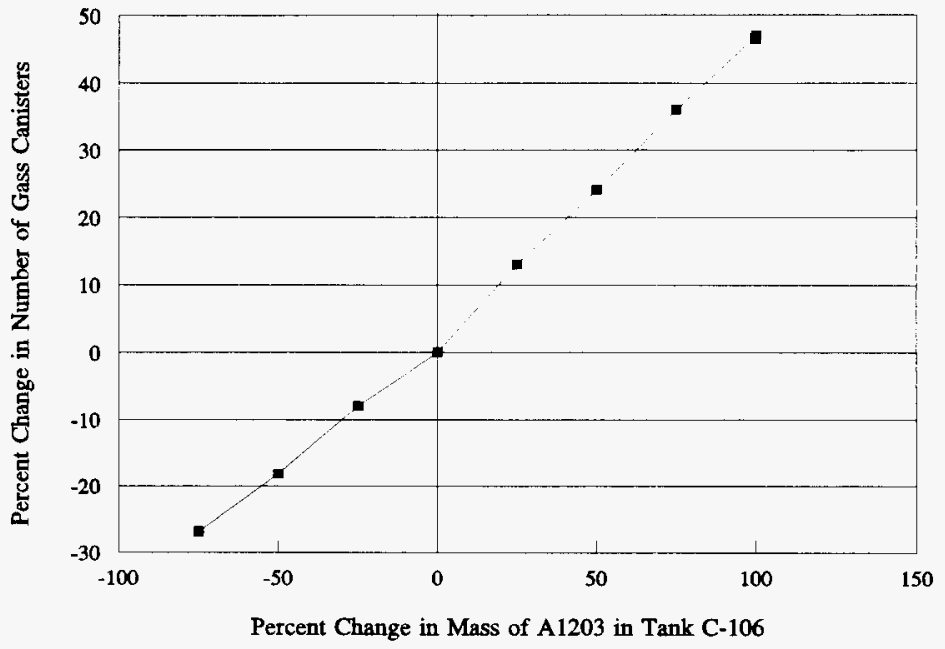


WHC-SD-WM-TI-768

Revision 0

Figure 6-13. Effect of Liquidus Temperature, Nepheline, and Composition Variability Study Limits on Volume of Glass versus $\mathrm{Fe}_{2} \mathrm{O}_{3}$ in Tank 241-C-106 Waste.

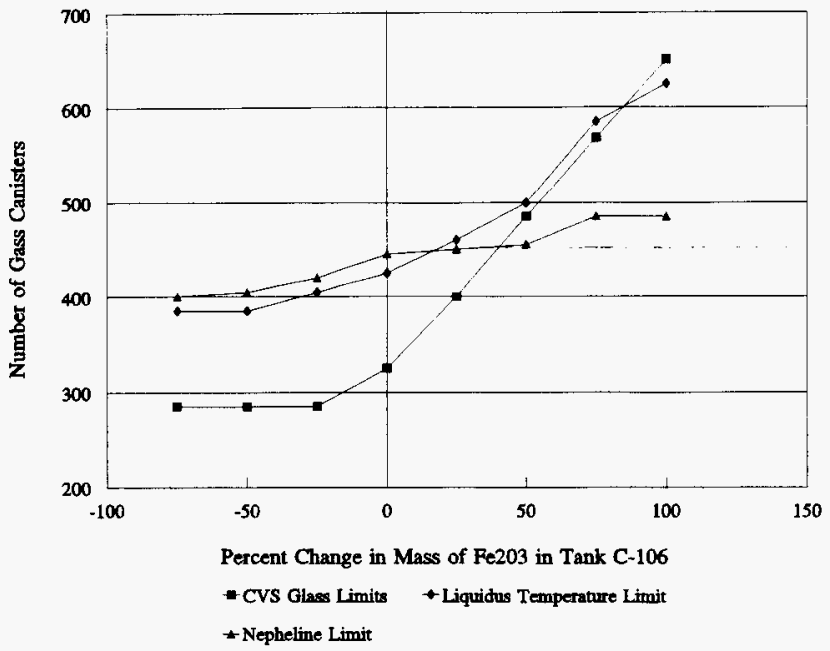

Figure 6-14. Effect of High-Level Waste Glass Model and Composition Variability Study Limits on Volume of Glass versus $\mathrm{Fe}_{2} \mathrm{O}_{3}$ in Tank 241-C-106 Waste.

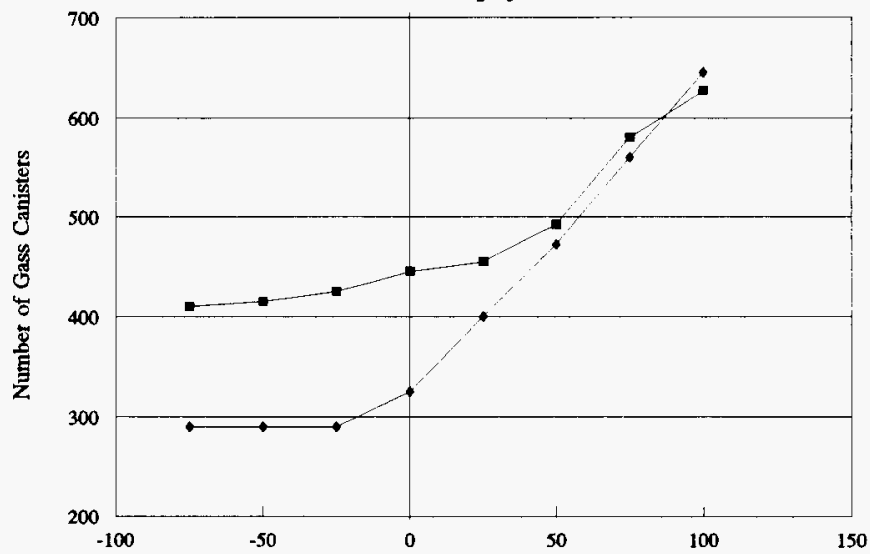

Percent Change in Mass of Fe203 in Tank C-106

- HLW Glass Model Predictions - CVS Glass Limits 


\section{WHC-SD-WM-TI-768}

\section{Revision 0}

Figure 6-15. $\mathrm{Fe}_{2} \mathrm{O}_{3}$ and $\mathrm{Al}_{2} \mathrm{O}_{3}$ Concentrations in Glass versus $\mathrm{Fe}_{2} \mathrm{O}_{3}$ in Tank 241-C-106 Waste.

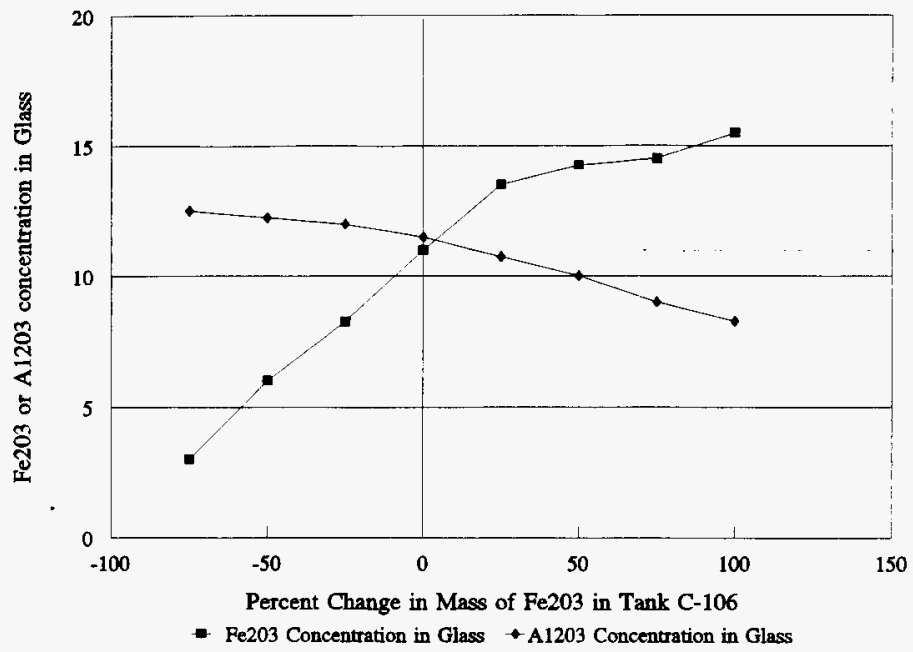

Figure 6-16. Change in Volume of Glass versus Percent Change of $\mathrm{Fe}_{2} \mathrm{O}_{3}$ in Tank 241-C-106 Waste.

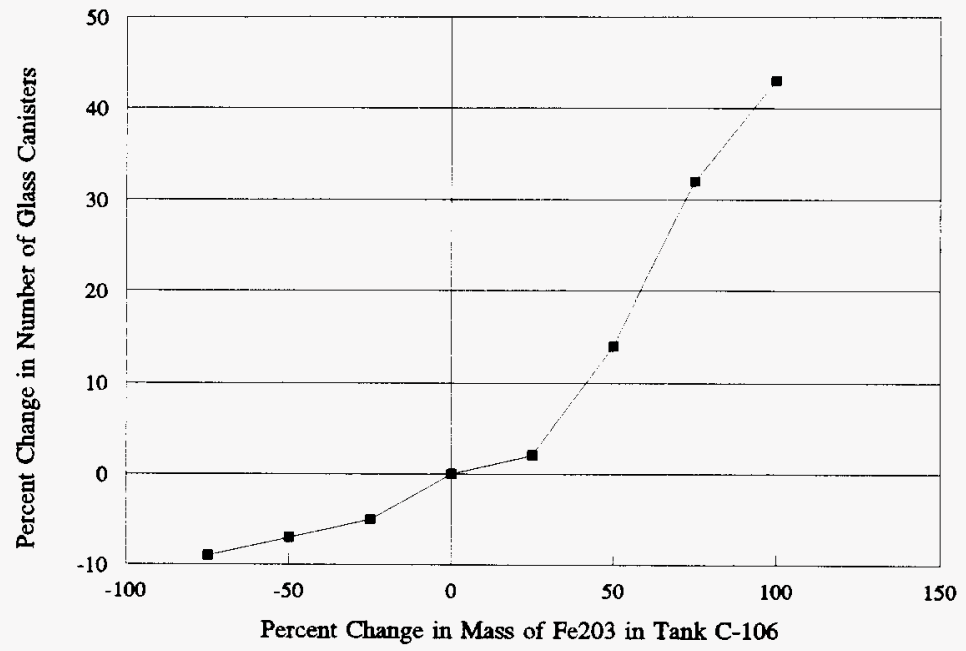




\section{Revision 0}

Figures 6-13 through 6-16 show the effect of varying the amount of $\mathrm{Fe}_{2} \mathrm{O}_{3}$ in Tank 241-C-106 waste. In Figure 6-13, the CVS single component glass, liquidus temperature and nepheline limits are presented as a function of $\mathrm{Fe}_{2} \mathrm{O}_{3}$. Glass model predictions and CVS single component glass limits are plotted as a function of $\mathrm{Fe}_{2} \mathrm{O}_{3}$ in Figure 6-14. In this case, the CVS single component glass limits tend to underpredict the volume of glass by 35 to 40 percent in the low $\mathrm{Fe}_{2} \mathrm{O}_{3}$ region, but produce better results in the higher $\mathrm{Fe}_{2} \mathrm{O}_{3}$ region of the glass composition space. The $\mathrm{Fe}_{2} \mathrm{O}_{3}$ and $\mathrm{Al}_{2} \mathrm{O}_{3}$ glass compositions are shown in Figure 6-15, with the crossover from nepheline to liquidus temperature control occurring in the region between 100 and 125 percent of the baseline $\mathrm{Fe}_{2} \mathrm{O}_{3}$ inventory $\left(\mathrm{Al}_{2} \mathrm{O}_{3}\right.$ to $\mathrm{Fe}_{2} \mathrm{O}_{3}$ ratio of 0.83 to 1.03 ). In the previous examples, the nepheline to liquidus transition occurred in the region defined by $\mathrm{Al}_{2} \mathrm{O}_{3}$ to $\mathrm{Fe}_{2} \mathrm{O}_{3}$ ratios of 0.74 to 0.77 . The difference in this case might be related to the radical shift in first and second-order liquidus temperature model predictions over this composition range (C106A-3 and C106A-4 glasses in Table 5-9). The first and second-order models tend to underpredict the liquidus temperature (by 30 to $50{ }^{\circ} \mathrm{C}$ ) in the region where $\mathrm{Al}_{2} \mathrm{O}_{3}$ and $\mathrm{Fe}_{2} \mathrm{O}_{3}$ concentrations are 12.5 to $13 \mathrm{wt} \%$ in glass, and overpredict liquidus temperature for the same family of glasses (by 40 to $60^{\circ} \mathrm{C}$ ) where the $\mathrm{Al}_{2} \mathrm{O}_{3}$ and $\mathrm{Fe}_{2} \mathrm{O}_{3}$ concentrations have been reduced to 9 to $9.5 \mathrm{wt} \%$. With this level of uncertainty, additional data are needed to more accurately predict the transition from nepheline to liquidus temperature control for the Tank 241-C-106 family of $\mathrm{Fe}_{2} \mathrm{O}_{3}$ rich glasses.

In Figure 6-16, the relative glass volume is shown as a function of Tank 241-C-106 $\mathrm{Fe}_{2} \mathrm{O}_{3}$ concentration. Based on current projections, the glass volume increases 43 percent with an increase of 100 percent in the amount of $\mathrm{Fe}_{2} \mathrm{O}_{3}$ in the waste, but decreases only 8.5 percent with a 75 percent decrease in $\mathrm{Fe}_{2} \mathrm{O}_{3}$. Again, as in the case of Tank 241-AZ-101 waste, the volume of glass increases strongly with the amount of $\mathrm{Fe}_{2} \mathrm{O}_{3}$, but decreases only marginally under nepheline control as the amount of $\mathrm{Fe}_{2} \mathrm{O}_{3}$ is reduced in the waste. If the mass of all components except $\mathrm{Al}_{2} \mathrm{O}_{3}$ or $\mathrm{Fe}_{2} \mathrm{O}_{3}$ is constant, the volume of $\mathrm{C}-106$ glass should increase 4.3 and 4.6 percent with a 10 percent increase in the amount of $\mathrm{Fe}_{2} \mathrm{O}_{3}$ or $\mathrm{Al}_{2} \mathrm{O}_{3}$, respectively, and decrease 1.1 and 3.6 percent with a decrease of 10 percent in the amount of $\mathrm{Fe}_{2} \mathrm{O}_{3}$ or $\mathrm{Al}_{2} \mathrm{O}_{3}$ in this waste. These figures can also be used to estimate the cost of overestimating or under-estimating the mass of these components (based on a repository disposal fee of $\$ 356,000$ per canister).

\subsubsection{Glass-Limiting Components in the Waste}

Tank core samples have been commonly used as a primary basis for estimating the composition of most HLW at the Hanford Site. Recently, a study was conducted to evaluate the statistical variability of samples from Tanks 241-BX-107, 241-T-107, 241-C-109, 241-C-110, and 241-C-112 (Jensen 1994). The results generally indicate that 2 to 4 cores may be required at an average cost of $\$ 1$ million per core for the analysis of most components to be within 100 percent of the mean value in each tank ( 95 percent confidence level). Statistical methods also have been used to assess homogeneity errors in SSTs with replicate samples (Jensen and Liebetrau 1988). Such errors appear to be caused by vertical 


\section{Revision 0}

and horizontal inhomogeneities in the tank, which can seriously affect the accuracy of any sampling program. Tank-by-tank inventories are needed to define the retrieval sequence, downstream processing, pretreatment, and TWRS flowsheet for the processing of the HLW inventory.

Glass models can be used to estimate the most important components in the waste and the composition accuracy required for glass formulation purposes. These predictions are based on the minimum change (in waste concentration) needed to induce a $50{ }^{\circ} \mathrm{C}$ increase or decrease in the output of the second-order liquidus temperature model or a 5 percent change in the nepheline limit for Tanks 241-AZ-101 and 241-C-106 glasses. . The results are summarized in Tables 6-21, 6-22, 6-23, and 6-24.

Table 6-21. Tank 241-AZ-101 Base Case Glass Composition.

\begin{tabular}{|l|c|c|c|c|}
\hline \multicolumn{1}{|c|}{ Component } & Frit (kg) & Waste (kg) & $\begin{array}{c}\text { Tank 241-AZ-101 } \\
\text { glass (kg) }\end{array}$ & $\begin{array}{c}\text { Tank 241-AZ-101 } \\
\text { glass (wt \%) }\end{array}$ \\
\hline $\mathrm{SiO}_{2}$ & 125,000 & 3,017 & 128,017 & 42.3 \\
\hline $\mathrm{B}_{2} \mathrm{O}_{3}$ & 18,000 & 230 & 18,230 & 6.0 \\
\hline $\mathrm{Na}_{2} \mathrm{O}^{*}$ & 37,000 & 14,605 & 51,605 & 17.0 \\
\hline $\mathrm{Li}_{2} \mathrm{O}$ & 9,000 & 37 & 9,037 & 3.0 \\
\hline $\mathrm{CaO}$ & 0 & 821 & 821 & 0.3 \\
\hline $\mathrm{MgO}$ & 0 & 244 & 244 & 0.1 \\
\hline $\mathrm{Fe}_{2} \mathrm{O}_{3}$ & 0 & 34,444 & 34,444 & 11.4 \\
\hline $\mathrm{Al}_{2} \mathrm{O}_{3}$ & 0 & 25,282 & 25,282 & 8.4 \\
\hline $\mathrm{ZrO}_{2}$ & 0 & 11,445 & 11,445 & 3.8 \\
\hline $\mathrm{Cr}_{2} \mathrm{O}_{3}$ & 0 & 407 & 404 & 0.1 \\
\hline $\mathrm{MnO}_{2} \mathrm{O}$ & 0 & 1,152 & 1,152 & 0.4 \\
\hline $\mathrm{NiO}^{2}$ & 0 & 1,367 & 1,367 & 0.5 \\
\hline $\mathrm{P}_{2} \mathrm{O}_{5}$ & 0 & 1,545 & 1,545 & 0.5 \\
\hline
\end{tabular}

*The fraction of $\mathrm{Na}_{2} \mathrm{O}$ in waste will vary with washing efficiency. 
WHC-SD-WM-TI-768

Revision 0

Table 6-22. Waste Concentration Change Needed to Induce a $50^{\circ} \mathrm{C}$ Change in Liquidus Temperature $\left(T_{\mathcal{L}}\right)$ or 5 Percent Change in the Nepheline Limit for Tank 241-AZ-101 Glass.

\begin{tabular}{|l|c|c|c|c|}
\hline Component & Source (\% frit/\% waste) & $\begin{array}{c}\text { Component } \\
\text { contribution to } \\
T_{\mathrm{L}},{ }^{\circ} \mathrm{C}\end{array}$ & $\begin{array}{c}\text { Percent change } \\
\text { needed for } 50{ }^{\circ} \mathrm{C} \\
\text { increase or } \\
\text { decrease in } \mathrm{T}_{\mathrm{L}}\end{array}$ & $\begin{array}{c}\text { Percent change } \\
\text { needed for } 5 \% \\
\text { change in } \\
\text { nepheline limit }\end{array}$ \\
\hline $\mathrm{SiO}_{2}$ & Frit $97.64 \% /$ Waste $2.36 \%$ & -244.17 & 867 & 339 \\
\hline $\mathrm{B}_{2} \mathrm{O}_{3}$ & Frit $98.74 \% /$ Waste $1.26 \%$ & 115.24 & 3,400 & \\
\hline $\mathrm{Na}_{2} \mathrm{O}$ & Frit $71.70 \% /$ Waste $28.30 \%$ & 114.45 & 154 & 85.9 \\
\hline $\mathrm{Li}_{2} \mathrm{O}$ & Frit $99.59 \% /$ Waste $0.41 \%$ & -23.25 & 5.240 & \\
\hline $\mathrm{CaO}$ & Waste $100 \%$ & 10.64 & 470 & \\
\hline $\mathrm{MgO}_{\mathrm{gaO}}$ & Waste $100 \%$ & -2.97 & 1,683 & \\
\hline $\mathrm{Fe}_{2} \mathrm{O}_{3}$ & Waste $100 \%$ & 358.96 & 13.9 & \\
\hline $\mathrm{Al}_{2} \mathrm{O}_{3}$ & Waste $100 \%$ & 369.93 & 13.5 & 49.6 \\
\hline $\mathrm{ZrO}_{2}$ & Waste $100 \%$ & 73.16 & 68.3 & \\
\hline $\mathrm{Cr}_{2} \mathrm{O}_{3}$ & Waste $100 \%$ & 48.32 & 103.4 & \\
\hline $\mathrm{MnO} \mathrm{NiO}_{\mathrm{N} O}$ & Waste $100 \%$ & 89.98 & 55.6 & \\
\hline $\mathrm{P}_{2} \mathrm{O}_{5}$ & Waste $100 \%$ & 15.95 & 313.5 & \\
\hline
\end{tabular}

Table 6-23. Tank 241-C-106 Base Case Glass Composition.

\begin{tabular}{|l|c|c|c|c|}
\hline Component & Frit (kg) & Waste (kg) & $241-\mathrm{AZ}-101$ glass $(\mathrm{kg})$ & 241-AZ-101 glass (wt\%) \\
\hline $\mathrm{SiO}_{2}$ & 140,000 & 161,960 & 301,960 & 41.9 \\
\hline $\mathrm{B}_{2} \mathrm{O}_{3}$ & 64,300 & 50 & 64,350 & 8.9 \\
\hline $\mathrm{Na}_{2} \mathrm{O}$ & 0 & 102,926 & 102,926 & 14.3 \\
\hline $\mathrm{Li}_{2} \mathrm{O}$ & 18,000 & 0 & 18,000 & 2.5 \\
\hline $\mathrm{CaO}$ & 0 & 17,720 & 17,720 & 2.5 \\
\hline $\mathrm{MgO}$ & 0 & 11,596 & 11,596 & 1.6 \\
\hline $\mathrm{Fe}_{2} \mathrm{O}_{3}$ & 0 & 79,381 & 79,381 & 11.0 \\
\hline $\mathrm{Al}_{2} \mathrm{O}_{3}$ & 0 & 82,382 & 82,382 & 11.5 \\
\hline $\mathrm{ZrO}_{2}$ & 0 & 2,956 & 2,956 & 0.4 \\
\hline $\mathrm{Cr}_{2} \mathrm{O}_{3}$ & 0 & 1,531 & 1,531 & 0.2 \\
\hline $\mathrm{MnO} \mathrm{O}$ & 0 & 3,105 & 3,105 & 0.4 \\
\hline $\mathrm{NiO}$ & 0 & 1,277 & 1,277 & 0.2 \\
\hline $\mathrm{P}_{2} \mathrm{O}_{5}$ & 0 & 6,033 & 6,033 & 0.8 \\
\hline
\end{tabular}




\section{Revision 0}

Table 6-24. Waste Concentration Change Needed to Induce a $50{ }^{\circ} \mathrm{C}$ Change in Liquidus Temperature $\left(T_{D}\right)$ or 5 Percent Change in the Nepheline Limit for Tank 241-C-106 Glass.

\begin{tabular}{|l|c|c|c|c|}
\hline Component & Source (\% Frit/\% Waste) & $\begin{array}{c}\text { Component } \\
\text { contribution to } \\
\mathrm{T}_{\mathrm{L}},{ }^{\circ} \mathrm{C}\end{array}$ & $\begin{array}{c}\text { Percent change } \\
\text { reqd. for 50 } \\
\text { increase or } \\
\text { decrease in } \mathrm{T}_{\mathrm{L}}\end{array}$ & $\begin{array}{c}\text { Percent change } \\
\text { reqd. for 5\% } \\
\text { change in } \\
\text { nepheline limit }\end{array}$ \\
\hline $\mathrm{SiO}_{2}$ & Frit $46.36 \% /$ Waste $53.64 \%$ & -251.25 & 37 & 15.0 \\
\hline $\mathrm{B}_{2} \mathrm{O}_{3}$ & Frit $99.92 \% /$ Waste $0.08 \%$ & 171.07 & $-3,650$ & \\
\hline $\mathrm{Na}_{2} \mathrm{O}$ & Waste $100 \%$ & 96.02 & 52 & 24.9 \\
\hline $\mathrm{Li}_{2} \mathrm{O}$ & Frit $100 \%$ & -19.48 & 257 & \\
\hline $\mathrm{CaO}$ & Waste $100 \%$ & 86.41 & 58 & \\
\hline $\mathrm{MgO}$ & Waste $100 \%$ & 12.49 & 400 & \\
\hline $\mathrm{Fe}_{2} \mathrm{O}_{3}$ & Waste $100 \%$ & 344.77 & 14.5 & \\
\hline $\mathrm{Al}_{2} \mathrm{O}_{3}$ & Waste $100 \%$ & 366.50 & 13.6 & 31.1 \\
\hline $\mathrm{ZrO}_{2}$ & Waste $100 \%$ & 7.94 & 630 & \\
\hline $\mathrm{Cr}_{2} \mathrm{O}_{3}$ & Waste $100 \%$ & 79.78 & 62.7 & \\
\hline $\mathrm{MnO}$ & Waste $100 \%$ & 101.97 & 49.0 & \\
\hline $\mathrm{NiO}$ & Waste $100 \%$ & 6.27 & 798 & \\
\hline $\mathrm{P}_{2} \mathrm{O}_{5}$ & Waste $100 \%$ & 26.13 & 191.4 & \\
\hline
\end{tabular}

These models indicate that only two components $\left(\mathrm{Fe}_{2} \mathrm{O}_{3}\right.$ and $\left.\mathrm{Al}_{2} \mathrm{O}_{3}\right)$ need to be known with reasonable precision (to within 15 percent or their true values) to estimate the amount of glass likely to be produced from Tank 241-AZ-101 waste, and four components $\left(\mathrm{SiO}_{2}, \mathrm{Na}_{2} \mathrm{O}\right.$, $\mathrm{Fe}_{2} \mathrm{O}_{3}$ and $\mathrm{Al}_{2} \mathrm{O}_{3}$ ) to estimate the volume of glass from Tank 241-C-106 waste. Other components from a glass formulation perspective that need to known (to with 100 percent of their true values) are $\mathrm{Na}_{2} \mathrm{O}, \mathrm{MnO}$, and $\mathrm{ZrO}_{2}$ for Tank 241-AZ-101 waste and $\mathrm{Cr}_{2} \mathrm{O}_{3}, \mathrm{MnO}$, and $\mathrm{CaO}$ for Tank 241-C-106 waste. While it may be desirable to obtain as much information as possible, the volume and composition of most glasses can be reasonably determined from $\mathrm{Fe}_{2} \mathrm{O}_{3}$ and $\mathrm{Al}_{2} \mathrm{O}_{3}$ composition data, together with some knowledge of $\mathrm{Cr}_{2} \mathrm{O}_{3}, \mathrm{MnO}$, noble metals $\left(\mathrm{Ag}_{2} \mathrm{O}, \mathrm{PdO}, \mathrm{Rh}_{2} \mathrm{O}_{3}\right.$, and $\left.\mathrm{Ru}_{2} \mathrm{O}_{3}\right)$, and the semi-soluble components in the waste $\left(\mathrm{P}_{2} \mathrm{O}_{5}\right.$ and $\left.\mathrm{SO}_{4}\right)$. 


\subsection{BALANCE OF PROCESS}

Some components may have a significant effect on the operability of the vitrification facility. This section provides a discussion of feed processability issues unrelated to glass production estimates. Offgas and emissions control systems could be affected by the amount of mercury, cadmium, and other volatile components in the waste while chlorides and sulfates could contribute to the general corrosion of offgas system components. Criticality controls will undoubtedly be effected by actinides in the waste. In addition to other considerations, nitric oxide emissions from the Phase I immobilization facility could have a effect on allowable release rates from the Hanford Site. These issues will be addressed in this section of the report.

\subsubsection{Mercury}

Mercury was occasionally added as mercuric nitrate to uranyl nitrate feedstock in the REDOX and PUREX processes to suppress the volatility of ${ }^{131}$ I when relatively short-cooled fuels were dissolved. Records indicate that mercury was used from 1952 through 1967, predominately in the PUREX process. During this period, mercury was added to the dissolvers about 25 percent of the time at a rate of approximately $0.77 \mathrm{~kg}$ of mercuric nitrate per 6 tons of uranium. Altogether, the total mercury inventory at the Hanford Site is estimated to be in the range of $2,000 \mathrm{~kg}$, with 88 percent in the high-level PUREX waste and the balance in the high-level REDOX waste (Wagner 1992, Allen 1976). The mercury concentration varies from 830 to $1,400 \mathrm{p} / \mathrm{M}$ in the high-level PUREX sludge. An analysis of sludge samples from Tank 241-AY-102 shows $40 \mathrm{p} / \mathrm{M}$ of mercury (Voogd 1988). Samples from Tank 241-C-106 suggest the mercury concentration is between 42 to $327 \mathrm{p} / \mathrm{M}$ (McCown 1988). On a dried solids basis, as much as $0.017 \mathrm{wt} \%$ mercury $(173 \mathrm{p} / \mathrm{M})$ could be present in the combined Phase I feed from Tanks 241-C-106 and 241-AY-102.

Traceable amounts of copper, lead, and mercury have been found in many of the SSTs, principally those with high-level B Plant and evaporator bottoms wastes. Nine of 12 SST farms were included in the sample population (all except Tank Farms AX, T, and TY). Mercury concentrations varied from 5 to $800 \mathrm{p} / \mathrm{M}$, with most samples being in the range of 30 to $350 \mathrm{p} / \mathrm{M}$. If the sludge-washing calculations for Tank 241-AY-102 are considered typical, melter feeds from the SSTs could contain as much as 75 to $875 \mathrm{p} / \mathrm{M}$ mercury.

A small amount of mercuric nitrate also was used in the plutonium reclamation facility to catalyze the dissolution of plutonium-aluminum alloy scrap. This usage was small between 1973 and 1976 when the waste was sent to the 200 West Area Tank Farms.

The solubility product of mercuric hydroxide is approximately $10^{-22}$, which means that at a $\mathrm{pH}$ of 10 , the mercuric ion concentration in solution is only $10^{-14}$ molar. The sludgewashing partitioning factor for mercuric iodide is assumed to be zero (Higley 1988). Given the extremely low solubility of mercuric oxides under alkaline $\mathrm{pH}$ conditions, most of the mercury will undoubtedly be found in the HLW feed streams. 
Mercury is relatively insoluble in borosilicate glass and tends to quantitatively volatilize at the operating temperature of the melter (Volf 1984). Volatility losses from the melter are believed to be affected by cold-cap coverage, plenum temperature, and feed/glass composition. Melter studies have indicated that as much as $\mathbf{5 0}$ percent of the mercury in the melter feed could volatilize in the melter (Table 4-1).

The Savannah River (SRS) plant reportedly used about 45 times as much mercury to catalyze the dissolution of aluminum-clad fuel elements. The DWPF flowsheet also shows a mercury feed rate of $19 \mathrm{~kg} /$ day to the mercury removal pretreatment step and $3 \mathrm{~kg} /$ day to the melter (Higley 1988). Process emissions from the SRS plant are controlled by venting mercury vapor from the processing tanks through the vessel vent header system condenser (formic acid vent condenser) and melter offgases through the offgas vent condenser. The overall emissions level is based on the saturation limit of mercury in the noncondensable gases emitted from the condensers. The current design is based on an exit temperature of $10{ }^{\circ} \mathrm{C}$, while release estimates are based on an operating temperature of $15^{\circ} \mathrm{C}$. Mercury release rates also are based in part on the volume of purge air required to control the hydrogen concentration in the chemical processing cell. Purge air requirements are predicated on maintaining the hydrogen concentration below 25 percent of the lower explosive limit. When the plant reaches full production, mercury emissions are estimated to be $0.155 \mathrm{~kg} /$ day from the formic acid vent condenser and $0.136 \mathrm{~kg} /$ day from the melter offgas condenser.

At the DWPF facility, it is anticipated that 85 percent of the mercury will be removed in the feed preparation process (via formic acid reduction) and 15 percent will be routed to the melter. If this distribution also applies to the Phase I immobilization facility, the melter feed could vary from 6.3 to 49 p/M mercury (for Tanks 241-C-106 and 241-AY-102 waste). On this basis, mercury emissions from the Phase I melter (rated at $1.0 \mathrm{MT} /$ day of glass @ 35 percent WOL) may range from 0.0022 to $0.0172 \mathrm{~kg} /$ day, with an average value of 0.0095 $\mathrm{kg} /$ day. Actual emissions could be substantially lower depending on the volume of purge air and operating temperature of the melter offgas condenser.

If the mercury decontamination factor across the melter is much less than 2.0 , it may not be possible to recycle mercury to extinction in the HLW vitrification plant. The estimated distribution of mercury is addressed in the current flowsheet (Orme 1995). Although the removal of mercury from the feed stream may not be necessary, the presence of even a small amount of mercury may require the use of DWPF-specified materials in the offgas system (Hastelloy C-22 for feed preparation and offgas handling equipment) and the segregation and purification of mercury from scrubber wastes for offsite disposal.

\subsubsection{Cadmium}

Cadmium oxide $(\mathrm{CdO})$ volatility is a concern because of the potential accumulation of cadmium-rich deposits in the melter offgas line. Such deposits were found to be minimal following the completion of the LFCM-8 melter run (Perez et al. 1993). At the entrance of 
the offgas line jumper, a shallow 0.01-cm thick deposit coated the inside of the pipe. The maximum volume of the deposit was estimated to be $0.00056 \mathrm{~m}^{3}$. An analysis of this deposit indicates cadmium was not enriched relative to other components in the feed. The $\mathrm{CdO}$ release rate from the melter was determined to be $0.65 \mathrm{~g} / \mathrm{h}$. This corresponds to a melter decontamination factor of approximately 350 , which is similar to decontamination factors previously established for aerosols of sodium and potassium (Goles and Nakaoka 1990). Less than 3 percent of the $\mathrm{CdO}$ exiting the melter was found to have deposited in the offgas line. Preliminary glass testing indicates that $\mathrm{CdO}$ is soluble up to $2.5 \mathrm{wt} \%$ in glass at $\mathrm{Fe}^{+2} / \mathrm{Fe}^{+3}$ ratio of 0.18 (Watrous 1987). Based on these estimates and the projected CdO composition of Tanks 241-AZ-101 and 241-AZ-102 wastes (1.80 and 3.54 wt\%, respectively), offgas line deposits (of $\mathrm{CdO}$ ) are unlikely to occur if Tanks 241-AZ-101 and 241-AZ-102 wastes are blended ( $2.84 \mathrm{wt} \% \mathrm{CdO})$. On the other hand, long term problems could arise if Tank 241-AZ-102 waste is processed separately and mechanical systems are not available to remove potential deposits from the melter offgas line. While CdO deposits may be a contributing factor, sodium metaborate and chloride salt deposits are likely to be a much more significant concern with respect to the melter offgas line.

\subsubsection{Chloride, Fluoride, and Sulfate}

Chloride and fluoride are expected to concentrate in the melter feed due to internal recycle of scrubber waste solutions in the vitrification plant. Preliminary estimates have been made as to the likely concentration of chloride and fluoride based on the HWVP material balance for NCAW (Tanks 241-AZ-101/241-AZ-102 waste) (Baker 1991). Two separate versions of the flowsheet were considered, one that assumes maximum recycle and the other that allows for purging a large fraction of the soluble components. The concentration of chloride increased by a factor of two in the recycle flowsheet to as much as $1,700 \mathrm{p} / \mathrm{M}$ in the feed preparation tank, while the concentration of fluoride increased by a factor of 1.7 . This chloride level is at the upper end of materials selection test data where some accelerated corrosion ( $>5$ mils/year) has been observed (Elmore and Jensen 1990). More frequent plugging of the melter offgas line is also possible due to the increased rate of salt deposition. In comparison, the feed preparation tank chloride level in the purge flowsheet was about $630 \mathrm{p} / \mathrm{M}$.

Most of the chloride, fluoride, and sulfate should be separated from the HLW stream during the sludge wash or enhanced sludge-washing processes. Estimated sludge-washing factors are on the order of 25 to 70 percent for each of these components based on characterization analysis of the core samples. However, these estimates are highly uncertain because the water washed solids were not analyzed for $\mathrm{Cl}, \mathrm{F}$, and $\mathrm{SO}_{4}$. The total chloride inventory in the Phase I waste could be as little as $723 \mathrm{~kg}$ (out of $926,000 \mathrm{~kg}$ of unwashed sludge). Based on sludge washing studies, it is conservatively assumed that most of the chloride associated with silver in the Tank 241-AY-102 waste, will remain in the water washed sludge that will be delivered to the Phase I HLW plant. The amount of fluoride and sulfate in the water washed sludge from all Phase I wastes is likely to be low but cannot be determined from the available core sample data. 
Salt deposits are commonly formed in the melter offgas line of LFCMs. These deposits usually consist of alkali-rich chlorides, sulfates, borates, and fluorides with entrained $\mathrm{Fe}_{2} \mathrm{O}_{3}$, spinel, and frit particles (Hutson 1994). During the IDMS melter test where these deposits were observed, the melter plenum was maintained at a temperature of 800 to $900^{\circ} \mathrm{C}$ and the offgas line at 300 to $350^{\circ} \mathrm{C}$. Ruthenium also was found in the IDMS offgas line deposits. Under very oxidizing conditions, $\mathrm{RuO}_{2}$ can be oxidized to $\mathrm{RuO}_{4}$, a toxic gas. $\mathrm{RuO}_{4}$ is very unstable and will probably decompose to $\mathrm{RuO}_{2}$ in the melter offgas line. However, most ruthenium was found to be associated with a spinel phase, which suggests that ruthenium-rich deposits were caused by entrainment rather than by volatilization of ruthenium. Table 6-25 shows the chemical composition of the offgas deposits.found during the IDMS tests with HWVP feeds (NCAW).

Table 6-25. Chemical Composition of Offgas Deposits.

\begin{tabular}{|l|c|c|}
\hline \multicolumn{1}{|c|}{ Component } & $\begin{array}{c}\text { After HWVP1 } \\
\text { (wt \%) }\end{array}$ & $\begin{array}{c}\text { After HWVP2 } \\
\text { (wt\%) }\end{array}$ \\
\hline $\mathrm{Na}$ & -- & 14.97 \\
\hline $\mathrm{Cs}$ & -- & 0.92 \\
\hline $\mathrm{Zn}$ & 0.13 & 0.13 \\
\hline $\mathrm{Cd}$ & 0.58 & 0.95 \\
\hline $\mathrm{F}$ & 0 & 0.01 \\
\hline $\mathrm{Cl}$ & 8.93 & 9.86 \\
\hline $\mathrm{SO}_{4}$ & 12.42 & 17.35 \\
\hline
\end{tabular}

HWVP $=$ Hanford Waste Vitrification Plant

In order to support material selection for HWVP, corrosion tests were performed using conservative (aggressive) process stream simulants and conditions. Corrosion limits of less than $125 \mu$ /year were set accordingly for tanks and process lines with no allowance for localized stress corrosion cracking, pitting, or crevice corrosion phenomenon. Certain materials were chosen for testing in a high-chloride and -fluoride environment, including 304L SS, Carpenter $20 \mathrm{Cb}-3$, Hastelloy ${ }^{1}$ C-276, Hastelloy C-22, Hastelloy G-3, Titanium Grade 7, Titanium Beta-C, and Allcorr (Elmore and Jensen 1990). These materials were tested in the presence of simulated offgas condensates with $80,000 \mathrm{p} / \mathrm{M}$ of chloride and $9,000 \mathrm{p} / \mathrm{M}$ of fluoride over a pH range of 1.0 to 3.0 and in applicable slurries with $20,000 \mathrm{p} / \mathrm{M}$ and 2,300 p/M of chloride and fluoride, respectively. Depending on $\mathrm{pH}$, several materials were identified as candidate materials for use in a high-halide environment. Hastelloy C-22 exhibited the lowest corrosion rates, generally less than $125 \mu /$ year. The

\footnotetext{
${ }^{1}$ Hastelloy is a trademark of Stellite Rod Division, Stoody Deloro Stellite, Incorporated.
} 
corrosion rates did not change appreciably as a function of chloride and fluoride concentration.

The bounding case for chloride appears to be a blend of tanks 241-C-106 and 241-AY-102 waste with an average chloride concentration of $705 \mathrm{p} / \mathrm{M}$ in the melter (assuming that all chloride in the supernate wash stays in the water washed sludge). The equivalent concentration in the recycle flowsheet could be as high as $1,400 \mathrm{p} / \mathrm{M}$ in the melter feed tank. This concentration is bounded by the off-gas condensate chloride concentration used in the materials corrosion test from which Hastelloy C-22 was identified as the preferred material of construction for the melter feed tank (Elmore and Jensen 1990). The worst case scenario for fluoride is again Tank $241-\mathrm{AY}-102$ waste, with $700 \mathrm{p} / \mathrm{M}$ of fluoride in the melter and $1,400 \mathrm{p} / \mathrm{M}$ in the melter feed tank based on the recycle flowsheet. For sulfate, the bounding condition is represented by Tank 241-AZ-101 waste, where the maximum sulfate concentration could be $115 \mathrm{p} / \mathrm{M}$ in the melter (@36 percent WOL). The only data from which a comparison can be made is the WVDP melter feed where the Inconel- 690 electrodes were not affected by $2,500 \mathrm{p} / \mathrm{M}$ of sulfate in the glass. Average flowsheet values and offgas scrubber purge stream concentrations are shown in the TWRS flowsheet (Orme 1995).

\subsubsection{Nitrogen Oxides}

Nitrogen oxide emissions could be on the order of 12 to $18 \mathrm{MT} /$ year when processing NCAW feed (from Tanks 241-AZ-101/241-AZ-102) through the vitrification process (at a rate of $1.0 \mathrm{MT} /$ day of glass @ 38 percent WOL) (Stegen 1991). Nitric oxide emissions and $\mathrm{NO}_{\mathrm{x}}$ treatment processes are identified in the TWRS flowsheet (Orme 1995). If nitrogen oxide emissions exceed $40 \mathrm{MT} / \mathrm{year}$, air quality regulations could require use of best available control technology (BACT), which would be determined on a case-by-case basis. Selective catalytic reduction (SCR) of nitrogen oxides with ammonia may be the preferred process for BACT control. The incremental cost of this system would be about $\$ 3$ million for the HWVP, with a projected annual cost of $\$ 950,000$ for maintenance and operation.

There are only a few examples where nitrogen balances have been determined across the melter. In two small-scale tests at SRS, about 30 to 50 percent of the nitrate was converted to nitrogen oxide in the melter (Crow and Sabatino 1984, Crow 1985). A 50 percent fractional conversion was obtained during a scale-glass melter run at SRS (Crow 1987). All the SRS tests were conducted with plenum heaters in the melters and with relatively high-volatile organic concentrations in the feed. During the PSCM-23 melter test, PNL, reported a 75 percent fractional conversion of nitrate to nitrogen oxide without plenum heaters in the melter. On this basis, it appears that higher fractional conversions (and a general increase in nitrogen oxide emissions) may be caused by lower plenum temperatures in the melter and by a lower concentration of volatile organics in the feed.

The dissociation of nitrogen peroxide into nitric oxide and oxygen starts to occur in the temperature range of $150{ }^{\circ} \mathrm{C}$ to $620^{\circ} \mathrm{C}$, and at temperatures above $700{ }^{\circ} \mathrm{C}$ nitric oxide will 


\section{Revision 0}

partially decompose into nitrogen and oxygen. About 95 to 99 percent of the nitric oxide can be destroyed in a high-temperature reducing flame (U.S. Patents 3,563,697, 3,232,713, and $2,673,141)$.

The melter feed preparation process appears to be the main source of nitrogen oxides. Nitrogen oxides are produced when formic acid is added to the feed to control redox conditions in the melter. Under these conditions, nitrites will be almost quantitatively reduced to nitrogen oxides in the acidified feed. Formic acid also has been known to produce appreciable amounts of hydrogen and ammonia during the feed preparation process. The AX, tank farm, and DST blends are expected to be the main nitrogen.oxide producers based on the projected nitrate and nitrite concentrations in these wastes.

\subsubsection{Criticality Control}

Table 6-26 provides an estimate of the plutonium inventories in Tanks 241-AZ-101, 241-AZ-102, 241-C-106, and 241-AY-102 [Powell 1996]).

Table 6-26. Plutonium Inventories in Tanks 241-AZ-101, 241-AZ-102, 241-C-106, and 241-AY-102.

\begin{tabular}{|c|c|}
\hline Tank & Plutonium, kg \\
\hline $241-\mathrm{AZ}-101$ & 19.25 \\
\hline $241-\mathrm{AZ}-102$ & 27.19 \\
\hline $241-\mathrm{C}-106$ & 97.5 \\
\hline $241-\mathrm{AY}-102$ & 8.64 \\
\hline
\end{tabular}

The source of the inventory estimate for 241-C-106 is Rogers (1994). The source of the other estimates is Tusler (1995). These estimates, which are based on the highest plutonium value in any tank sample, are considered the high estimates for the tanks.

Table 6-27 shows the maximum plutonium oxide $\left(\mathrm{PuO}_{2}\right)$ concentration in the NCAW melter feed (based on undiluted waste composition). 
Table 6-27. Maximum Plutonium Oxide Concentration in Phase I Melter Feeds.

\begin{tabular}{|c|c|c|c|}
\hline Tank & Total oxides $(\mathrm{kg})^{*}$ & $\mathrm{PuO}_{2}(\mathrm{~kg})$ & $\mathrm{PuO}_{2}(\mathrm{wt} \%)$ \\
\hline 241-AZ-101 & 109,214 & 21.82 & 0.02 \\
\hline $241-\mathrm{AZ}-102$ & 172,989 & 30.83 & 0.02 \\
\hline $241-\mathrm{C}-106$ & 485,519 & 110.55 & 0.02 \\
\hline 241-AY-102 & 31,646 & 9.80 & 0.03 \\
\hline
\end{tabular}

"Water washed oxides.

At SRS, the solubility of $\mathrm{PuO}_{2}$ was determined to be $4 \mathrm{wt} \%$ in Frit 21 and $7.0 \mathrm{wt} \%$ in Frit 411 (Plodinec 1979, Soper 1982). Both frits are essentially borosilicate glasses with different concentrations of $\mathrm{Na}_{2} \mathrm{O}, \mathrm{Li}_{2} \mathrm{O}$, and $\mathrm{TiO}_{2}$. Because the solubility of $\mathrm{PuO}_{2}$ in borosilicate glass appears to be at least 140 times the limiting concentration in NCAW waste, the precipitation of $\mathrm{PuO}_{2}$ as a separate phase is not anticipated. The possibility of a criticality incident in the DWPF melter due to the accumulation of $\mathrm{PuO}_{2}$ or plutonium metal has been examined at SRS (Soper 1982). The solubility of plutonium was found to greatly exceed the amount present in SRS waste. A thermodynamic analysis of $\mathrm{PuO}_{2}$ reduction shows that it will be one of the last oxides in the glass to reduce to metal. In particular, iron, nickel, and manganese oxides will be reduced to metal before $\mathrm{PuO}_{2}$ is reduced. Large amounts of iron and other metals in the melter would cause severe operating problems and shorting of the electrodes before any significant occurrence of plutonium accumulation.

Criticality control in the melter should be based on the possible accumulation of a plutonium-rich secondary phase at the bottom of the melter. Because the British have observed that cerium tends to form insoluble precipitates with actinides (plutonium and neptunium) in molten glass, the possibility of cerium, uranium, or some other carrier-induced precipitation of plutonium needs to be examined. If glass formulation testing shows that plutonium-rich crystals will not form or precipitate in the melter, criticality control should be based on dilution of plutonium in the glass such that $\mathrm{K}_{\mathrm{eff}}$ would be much less than 0.95 . 
WHC-SD-WM-TI-768

Revision 0

This page intentionally left blank. 
WHC-SD-WM-TI-768

Revision 0

\subsection{RESULTS AND CONCLUSIONS}

The primary purpose of this study is to assess the possible range of feed compositions and the effect of these compositions on the Phase I HLW immobilization process. The Phase I wastes consist of water washed (WW) and caustic washed (CW) sludges from Tanks 241-AZ-101, 241-AZ-102, 241-C-106, and 241-AY-102. For glass formulation purposes, several blends were also considered, including a nominal blend of these wastes derived from 80 percent of Tank 241-AZ-101, 80 percent of Tank 241-AZ-102, 37 percent of Tank 24 1-C-106, and 15 percent of Tank 241-AY-102 wastes... Estimates of the-feed composition were derived from the Tank Characterization Reports for Tanks 241-AZ-101, 241-AZ-102, and 241-AY-102, except for the sludge and aluminum inventories in Tank 241-AZ-101, and from the Data Transmittal package for Tank 241-C-106 (Hodgson 1995, Ryan 1995a, 1995b, Weiss 1987). The current inventory estimates for Tank 241-AZ-101 are based on the physical and chemical properties of the cores and average sludge level when the samples were taken in May 1989. At least one full-depth core sample has been taken from each of the Phase I tanks. Sludge washing studies were performed on three radioactive cores from Tanks 241-AZ-101 and 241-AZ-102 to characterize the composition of the washed solids. These results were used to estimate the composition of the water washed Phase I HLW feeds.

In this study, several different Phase I staging (retrieval, blending, and pretreatment) scenarios were used to generate example feed compositions for glass formulation, testing and glass sensitivity analysis. It should be recognized that these scenarios will not necessarily match the final process that is selected for Phase I.

Glass models and data from laboratory glass studies were used to estimate the achievable WOL and corresponding glass volume for various Phase I feeds. This study also takes into consideration possible variations in the feed composition due to uncertainties in the waste composition, blending or pretreatment processes that will be applied to these wastes. Glass property data have been obtained and evaluated for all Phase I glasses of primary interest. This includes glass property data correlations developed by PNNL that have been incorporated into computer codes (models) to facilitate calculation of estimated glass properties. These models were extensively used in the current evaluation. Key issues related to feed processability, feed composition uncertainty, and immobilization process technology are identified for future consideration in other tank waste disposal program activities. 


\subsection{GLASS COMPOSITION}

Melter feed compositions are expected to vary due to the range of compositions in the tanks, incomplete recovery and mixing of wastes, and batch composition differences depending on the waste consolidation plan. The corresponding glass composition will, therefore, vary for different waste types around a nominal glass composition for each waste. Changes in glass composition affect melt viscosity, electrical conductivity, and phase behavior. These properties determine the processability of the glass in a joule-heated melter. Glass composition also affects chemical durability and the related acceptability of the glass for the geologic repository. The optimum glass composition has to be determined for each waste.

The reference waste form in this study is borosilicate glass. Borosilicate glass has been recommended based on its ability to immobilize a wide range of wastes, insensitivity to radiation damage, and general properties such as thermal stability, chemical durability, and processability. The acceptable range of glass composition is normally defined by the range of compositions previously evaluated for the HWVP Project (the CVS range of compositions for which the statistically derived glass property models are considered valid).

Waste loading is defined as the weight percent of waste (oxides) in the HLW glass. This value is extremely important as it determines the required production rate of the melter and the total amount of glass produced during the Phase I HLW program.

\subsection{MELTER PERFORMANCE SENSITIVITIES}

Compounds or elements that require special treatment in the offgas may include tritium, mercury, ${ }^{14} \mathrm{C}$, and ${ }^{129} \mathrm{I}$. These elements will not be incorporated into glass at $1,150{ }^{\circ} \mathrm{C}$, except for a minor amount of mercury, and ${ }^{129} \mathrm{I}$ and must be captured in the offgas system and sent out as a secondary waste stream. Carbon-14 probably will be released to the atmosphere as long as Clean Air Act Amendments of 1990 standards are met. Chloride, fluoride, technetium, cesium, cadmium, and ruthenium oxide are partially soluble in glass but require special consideration in the offgas treatment system for recycle.

Noble metal oxides and alloys of silver, rhodium, palladium, and $\mathrm{RuO}_{2}$ are virtually insoluble in borosilicate glass. Previous tests and studies have indicated that accumulation of these metals can cause premature failure of the melter due to electrical short circuiting at concentrations as low as $0.1 \mathrm{wt} \%$ in glass. Designs developed by the Germans (KfK) have proven that accumulation of noble metals can be avoided by having a steeply sloped (75 degrees) bottom that allows precipitated noble metal particles to be drained out of a bottom drain. The Phase I water washed nominal blend contains $0.38 \mathrm{wt} \%$ noble metals $\left(\mathrm{Ag}_{2} \mathrm{O}, \mathrm{Ru}_{2} \mathrm{O}_{3}, \mathrm{Rh}_{2} \mathrm{O}_{3}\right)$. At 48 percent WOL in the glass, the noble metals concentration is $0.182 \mathrm{wt} \%$. If Phase I feeds are processed separately, Tanks 241-AZ-101, 241-AZ-102, and 241-C-106 glasses are estimated to contain $0.17,0.11$, and $0.24 \mathrm{wt} \%$ noble metal oxides, respectively. On the basis of recent grab samples from Tank 241-C-106, the bounding noble 
metal oxide concentration could be as high as $0.52 \mathrm{wt} \%$ in glass because of the amount of silver and ruthenium in this waste. This noble metals concentration is likely to cause premature failure of the melter electrodes and bottom refractory (based on the low melting temperature for silver $\left[960^{\circ} \mathrm{C}\right]$ and laboratory-scale tests performed with feeds containing from 0.33 to $0.46 \mathrm{wt} \%$ noble metals). An added concern is the high silver inventory in Tank 241-AY-102, with 1.85 wt\% silver oxide $\left(\mathrm{Ag}_{2} \mathrm{O}\right)$. If the noble metals concentration is determined to be too high, other wastes should be considered as potential feed stock for mitigating the high silver and ruthenium inventories in Tanks 241-C-106 and 241-AY-102. A bottom drain melter could also be used to address high silver inventories in the Phase I feed tanks.

\subsection{MELTER TECHNOLOGY}

Additional information has recently become available on performance of the hightemperature melter (HTM) and high-temperature glasses. Tests with a refractory-lined HTM indicate that the melt-rate capacity (at $1,350^{\circ} \mathrm{C}$ ) is only about 10 percent higher than the capacity of the low-temperature melter (LTM) $\left(\right.$ at $\left.1,150^{\circ} \mathrm{C}\right)$. Dissolution of refractory components into the glass increases aluminum and chrome levels and thus reduces the previously expected waste oxide loading advantage of the LTM (if corrosion source term components are included in calculating the liquidus temperature limits for glass formulation). Rapid corrosion of the melter electrodes also indicates that development of the HTM is likely to be more expensive than originally anticipated due to the need to identify and test more exotic (and expensive) electrode materials.

For high-nickel, -chromium, or -iron feeds, spinel precipitation and sludge accumulation problems are likely to occur in the melter. The precipitation and settling characteristics of spinel need to be assessed under different operating conditions. Viscosity and electrical conductivity measurements are needed to determine whether spinel phase enriched sludge deposits are primarily a mechanical or electrical problem in the melter. Glass melts containing from 2 to $10 \mathrm{vol} \%$ crystals are known to have approximately Newtonian viscoelastic behavior (Plodinec 1986).

Glass property data also indicate that precipitation of sludge forming solids (spinel phases) limits the achievable waste oxide loading for Tanks 241-AZ-101/241-AZ-102 wastes. If a practical sludge removal system were developed for the LTM (or alternative melter), it would be feasible to process glasses that contain a small fraction of undissolved solids (precipitated crystals). Several different approaches may be potentially promising, including: (1) a cone-shaped melter bottom, bottom electrode and drain system, (2) a detachable side entering drain with features to induce flow, (3) a ceramic stir or bubbler system to mobilize the solids and the injection of low viscosity glass to purge the sludge, or (4) a top entering vacuum removal system, such as the one developed by PNNL for West Valley (evacuated canister design) (Barnes 1989). 
Glass formulation results indicate the WOL of Tank 241-AZ-101/241-AZ-102 wastes could be increased 30 to 40 percent if the solids precipitation limits (liquidus temperature constraints) were relaxed. For example, optimum formulations for the HTM contain as much as $50 \mathrm{wt} \%$ NCAW waste (and 1.5 to $4.6 \mathrm{vol} \%$ crystals because of refractory corrosion). Similar glasses can be formulated for the LTM that contain from $33 \mathrm{wt} \%$ NCAW (with no crystallinity), to 40 or $45 \mathrm{wt} \% \mathrm{NCAW}$ (with 0.4 to $0.9 \mathrm{vol} \%$ crystals). If a practical sludge removal system were developed, LTM glasses could be formulated beyond the liquidus temperature limit to possibly match the waste loading capabilities of the HTM, significantly reducing the predicted life-cycle costs for the LTM. If the liquidus temperature limit is raised from 1,050 to $1,100^{\circ} \mathrm{C}$, for example, approximately 53 fewer-canisters $(10.7$ percent less glass) should be produced from the nominal blend feed.

Based on SSHTM and RSM-scale melter tests, the melt-rate capacity of the melter could probably be improved by formulating lower viscosity glasses for the melter. These glasses, however, are likely to increase refractory corrosion rates in the melter and could lead to premature failure of the refractory envelope.

\subsection{PHASE I GLASS PROPERTIES}

Based on current models, iron and aluminum are the main components that control the volume and composition of the Phase I glasses. Liquidus temperature and precipitation of nepheline $\left(\mathrm{NaAlSiO}_{4}\right)$ in the canister glass are the limiting properties of interest for most of these glasses. Liquidus temperature is important because this is the temperature where insoluble crystals will precipitate from the glass and may clog the pour spout or possibly short the electrodes in the melter (if the sludge phases are electrically conductive). Precipitation of nepheline during CCC is important because this is likely to produce an unacceptable HLW glass due to a substantial increase in normalized boron PCT release (due to a diminished amount of aluminum in the glass). Certain data were lacking with respect to the glass composition region of interest for the Phase I feeds. PNNL provided glass formulation support by experimentally evaluating properties of glasses in this composition region. Unpublished glass property data were also obtained from Westinghouse Savannah River Company. These data were used to developed improved data correlations and calculational models for the Phase I wastes. Glass work produced significant results in the following areas:

- Significant component interaction effects were noted in several Phase I glasses. The most important interaction is the effect of aluminum on the solubility of iron (reducing aluminum increases the solubility of iron). Aluminum and iron have a dominant effect on the liquidus temperature of the Phase I glasses, while aluminum, silica, and sodium control the nepheline forming properties of the glass.

- Better liquidus temperature models are being developed from the current database and a new set of glasses are being formulated around a spinel-forming baseline 


\section{Revision 0}

composition, with targeted variations in $\mathrm{Al}_{2} \mathrm{O}_{3}, \mathrm{~B}_{2} \mathrm{O}_{3}, \mathrm{Cr}_{2} \mathrm{O}_{3}, \mathrm{Fe}_{2} \mathrm{O}_{3}, \mathrm{Li}_{2} \mathrm{O}, \mathrm{MgO}$, $\mathrm{MnO}, \mathrm{Na}_{2} \mathrm{O}$, and $\mathrm{SiO}_{2}$ to measure the effect of each component on the liquidus temperature of spinel. Spinel structures are represented by the formulated $\mathrm{M}^{\mathrm{II}} \mathrm{M}_{2}{ }^{\mathrm{III}} \mathrm{O}_{4}$, where $\mathrm{M}^{\mathrm{II}}$ consists of di-valent $\mathrm{Fe}, \mathrm{Mg}$, or $\mathrm{Mn}$ and $\mathrm{M}^{\mathrm{III}}$ tri-valent $\mathrm{Fe}$, $\mathrm{Cr}$, or Al.

- Precipitation of nepheline appears to be a significant issue for certain feeds. Significant progress was made in FY 1996 in determining the composition ranges where nepheline precipitation could be a problem and estimating the possible durability effects of nepheline precipitation.

- Glass property models may be used to formulate and estimate the volume of HLW glasses. Based on these models and glass property data, the maximum waste oxide loading for the Phase I glasses varies from 29.78 to $30.65 \mathrm{wt} \%$ on an adjusted feed oxide basis. This indicates there is a 17 percent contingency or operating margin between he maximum theoretical waste loading and the minimum 25 percent adjusted feed oxide basis specified in the RFP. The 25 percent AFO appears to be conservative and an achievable value for Phase I.

The primary conclusions from these findings are as follows:

- The incentive for reducing the amount of aluminum in the Phase I waste (with caustic washing) is larger than previously thought.

- The iron solubility limit, as determined by liquidus temperature constraints, is lower than previously thought for many feeds, especially those with significant aluminum content. High concentrations of chromium and manganese also have an adverse effect on allowable iron compositions because of liquidus temperature effects.

- The nepheline region can be avoided by defining a minimum limit for $\mathrm{SiO}_{2}$ such that glasses with a normalized $\mathrm{SiO}_{2}$ content $\geq 0.62$ should not be susceptible to nepheline precipitation in the canister. The defined limit for nepheline is important for certain wastes, such as Tank 241-C-106 waste, where the WOL limits are likely to be determined by the nepheline forming characteristics of the glass.

- Glass property data and models should be considered in developing future baseline glass quantity estimates. Recent glass data identifies some important component interaction effects that were not well represented in simplified single component and multi-component constraint limits. A primary example is the effect of aluminum on iron solubility in glass. This interaction generally results in a larger glass volume and more incentive for caustic washing as compared to glass estimates derived from single component or multi-component limits. 
Three core samples of radioactive waste were recovered from the Phase I Tanks 241-AZ-101 and 241-AZ-102 in 1991. Small portions were used in laboratory-scale feed preparation and vitrification tests to produce representative samples of radioactive glass. The settling characteristics of the simulants did not match the behavior of the core samples in that the core samples settled much more quickly and achieved a much higher solids density than the simulants. The radioactive and simulant glasses proved to be highly durable.

Radioactive glasses were similar but slightly more leach resistant than comparable simulant glasses.

\subsection{GLASS SOLUBILITY LIMITS}

Because spinel phases have little effect on the properties of the glass, a chromium oxide limit is mainly needed to avoid operability problems in the melter and to minimize the possible precipitation and accumulation of spinel (unless a bottom drain melter is used). The $\mathrm{Cr}_{2} \mathrm{O}_{3}$ solubility limit for $\mathrm{LLW}$ glass varies from 0.48 to 1.04 percent, while the limit for high temperature glasses with a substantial amount of $\mathrm{Fe}_{2} \mathrm{O}_{3}$ varies from 0.6 to 0.93 percent. These results are important because they show that the solubility of $\mathrm{Cr}_{2} \mathrm{O}_{3}$ (as one of several spinel forming components in the waste) is only marginally increased by the temperature and composition of borosilicate and aluminum silicate glasses (thus reducing the potential advantage of the HTM).

Phosphate tends to form precipitates with calcium, rare earths, and lithium. Molten salt or scum layers may form from low-melting temperature phosphates and interfere with the operation and melt-rate capacity of the melter. A limit of $3.0 \mathrm{wt} \%$ phosphate should be acceptable because the Phase I glasses are projected to have less than $1.0 \mathrm{wt} \%$ phosphate and $0.85 \mathrm{wt} \%$ rare earths and should not be susceptible to phosphate induced scum or phase separation in the melter.

Although halides can form molten salts that accumulate on the glass surface, only minimal quantities of such salts have ever been observed. Presently, there is no generally applicable solubility limit for chloride. For Hanford Site LLW, a limit of $0.3 \mathrm{~g} \mathrm{Cl} / 100 \mathrm{~g}$ of waste oxide in the melter feed is being recommended for borosilicate glass based on the corrosion properties of chloride (in the melter offgas system) and the effect on cesium volarility. Halides are expected to distribute almost quantitatively to LLW.

The noble metals solubility limit is currently less than $0.25 \mathrm{wt} \% \mathrm{Ru}_{2} \mathrm{O}_{3}+\mathrm{PdO}+\mathrm{Rh}_{2} \mathrm{O}_{3}$ in glass (Kalia 1992a). This limit is well above the solubility limits derived from other studies that suggest flat-bottom melters may be susceptible to premature electrical failure at noble metals concentrations as low as $0.1 \mathrm{wt} \%$ in glass. 


\section{Revision 0}

\subsection{WASTE OXIDE LOADING AND GLASS VOLUME ESTIMATES}

The glass formulation models were used to test the bounding composition limits for each of the Phase I glasses. The main purpose of this effort is to determine the bounding conditions for each waste and the possible effects of a better retrieval sequence, blending strategy or pretreatment process on the number of glass canisters produced. Sensitivities were evaluated by increasing the allowable liquidus temperature to $1,100{ }^{\circ} \mathrm{C}$, or by assuming that $25,40,50$, and 75 percent of the $\mathrm{Al}_{2} \mathrm{O}_{3}$ could be removed (by caustic washing) and the glass reformulated to the maximum WOL. The glass models include the Fulcher first-order viscosity model (Section 5.3), spinel second-order liquidus temperature model (Section 5.5), second-order PCT B and Na release models and the nepheline model (Section 5.6). The results are summarized in Table 7-1.

Table 7-1. Glass Volume Estimates for Phase I Experimental Glasses.

\begin{tabular}{|l|c|c|c|c|c|c|c|}
\hline Waste & Base glass & $\begin{array}{c}\text { Base } \\
\text { glass, } \\
\text { cars. }\end{array}$ & $\begin{array}{c}\mathrm{T}_{\mathrm{L}} \text { limit } @ \\
1,100{ }^{\circ} \mathrm{C} \\
\text { cans. }\end{array}$ & $\begin{array}{c}25 \% \mathrm{Al}_{2} \mathrm{O}_{3} \\
\text { reduct, cans }\end{array}$ & $\begin{array}{c}40 \% \mathrm{Al}_{2} \mathrm{O}_{3} \\
\text { reduct, cans }\end{array}$ & $\begin{array}{c}50 \% \mathrm{Al}_{2} \mathrm{O}_{3} \\
\text { reduct, cans }\end{array}$ & $\begin{array}{c}75 \% \mathrm{Al}_{2} \mathrm{O}_{3} \\
\text { reduct, cans }\end{array}$ \\
\hline WW nom. blend & Nom-3 & 495 & 442 & 478 & - & 455 & $432^{\mathrm{a}}$ \\
\hline CW nom. blend & Nomc-1 & 417 & 384 & 411 & - & 400 & $397^{\mathrm{a}, \mathrm{b}}$ \\
\hline WW AZ blend & AZ-3 & 453 & 394 & 430 & $421(1)$ & - & - \\
\hline WW 241-C-106A & $\begin{array}{c}\text { Reform. } \\
\text { C106A-4 }\end{array}$ & 436 & N/A & 399 & - & 356 & 316 \\
\hline WW 241-C-106B & $\begin{array}{c}\text { Reform. } \\
\text { C106B-1 }\end{array}$ & 467 & N/A & 415 & - & 359 & $270^{\mathrm{c}}$ \\
\hline
\end{tabular}

WW $\quad=$ Water washed.

$\mathrm{CW} \quad=$ Caustic washed.

Nom. blend $=$ Nominal blend $(80$ percent $241-\mathrm{AZ}-101,80$ percent $241-\mathrm{AZ}-102$, 37 percent 241-C-106, 15 percent 241-AY-102).

$\mathrm{AZ}$ blend $\quad=$ Tank 241-AZ-101/241-AZ-102 blend.

241-C-106A $=$ Based on Weiss core sample analysis of Tank 241-C-106 waste.

241-C-106B = Based on Hara/McCown core sample analysis of Tank 241-C-106 waste.

cans $\quad=$ Number of DWPF canisters $(1,650 \mathrm{~kg}$ of glass per canister $)$.

N/A $\quad=$ Not applicable.

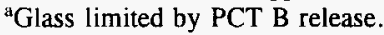

${ }^{b}$ Glass limited by $\mathrm{T}_{\mathrm{L}}$ limit (@ $\left.1,050{ }^{\circ} \mathrm{C}\right)$.

${ }^{\mathrm{c}}$ Glass limited by nepheline region. 


\section{Revision 0}

The glass composition boundaries are typically established by the liquidus temperature or nepheline composition limits for each glass. Experimental glasses were formulated by Pacific Northwest National Laboratory. In several instances, the experimental glasses were not formulated to the edge of the liquidus temperature or nepheline composition region and so these glass were reformulated with the glass models to optimize the potential WOL for each composition. The glass models predict that 53 fewer canisters will be produced if the liquidus temperature limit is raised from 1,050 to $1,100{ }^{\circ} \mathrm{C}$ for the water washed nominal blend. Approximately 40 to 78 canisters also could be saved if caustic washing processes are used to remove 50 percent of the $\mathrm{Al}_{2} \mathrm{O}_{3}$ from nominal blend feed (the $\mathrm{CW}$ nominal blend also contains about 50 percent of the of $\mathrm{Al}_{2} \mathrm{O}_{3}$ in the nominal blend feed). The caustic washing results for the nominal blend are slightly different because the glass models are nonlinear and the output is often affected by the initial composition of the waste (either water or caustic washed waste). For the AZ blend, the maximum WOL was reached at 40 percent $\mathrm{Al}_{2} \mathrm{O}_{3}$ removal based on the durability properties of the glass as measured by PCT boron release. By removing 40 percent of the $\mathrm{Al}_{2} \mathrm{O}_{3}$, approximately 32 canisters of glass could be saved if the $\mathrm{AZ}$ blend is caustic washed.

The glass models and glass property results were used to produce the following estimates for the water washed (base case) and caustic washed Phase I wastes (Tanks 241-AZ-101, 241-AZ-102, and 241-C-106 wastes and various blends of these wastes).

Table 7-2. Glass Volume Estimates for Unblended Phase I Wastes.

\begin{tabular}{|c|c|c|c|c|c|c|c|}
\hline $\begin{array}{l}\text { Phase I } \\
\text { tanks }\end{array}$ & $\begin{array}{c}\text { Water } \\
\text { washed waste }\end{array}$ & $\begin{array}{c}\text { Waste } \\
\text { inventory } \\
(\mathrm{MT})^{\mathbf{a}}\end{array}$ & $\begin{array}{c}\text { Base glass } \\
\text { WOL, } \\
\text { wt \% }\end{array}$ & $\begin{array}{l}\text { Base glass } \\
\text { AFO, wt } \%\end{array}$ & $\begin{array}{l}\text { Base' glass } \\
\text { (limit) }\end{array}$ & $\begin{array}{c}\text { Cans w/50\% } \\
\mathrm{Al}_{2} \mathrm{O}_{3} \text { removed } \\
\text { (limit) }\end{array}$ & $\begin{array}{c}\text { Cans } w / 75 \% \\
\mathrm{Al}_{2} \mathrm{O}_{3} \text { removed } \\
\text { (limit) }\end{array}$ \\
\hline 241-AZ-101 & 241-AZ-101 & 109.46 & 36.08 & 30.26 & $183\left(\mathrm{~T}_{\mathrm{L}}\right)$ & $154\left(T_{L}\right)$ & $145\left(T_{L}\right)$ \\
\hline 241-AZ-102 & 241-AZ-102 & 172.99 & 34.40 & 29.28 & $305\left(T_{\mathrm{L}}\right)$ & $265\left(T_{1}\right)$ & $268\left(T_{L}\right)$ \\
\hline $241-\mathrm{C}-106$ & 241-C-106A & 485.52 & 67.45 & 30.65 & 436 (neph.) & $356\left(T_{L} /\right.$ neph $)$ & 316 (low vis) \\
\hline Total & & 767.97 & & & 924 & 775 & 729 \\
\hline
\end{tabular}

${ }^{a} 100$ percent retrieval efficiency.

${ }^{b}$ DWPF canisters of glass limited by $T_{L}$ liquidus temperature or nepheline.

Phase I blend compositions

Nominal blend: $0.8 * 241-\mathrm{AZ}-101+0.8 * 241-\mathrm{AZ}-102+0.37 * 241-\mathrm{C}-106+0.15$

* 241-AY-102

AZ blend: $\quad 241-\mathrm{AZ}-101+241-\mathrm{AZ}-102$

AYC blend: $\quad 241-\mathrm{C}-106+241-\mathrm{AY}-102$

AYC-A blend: $241-\mathrm{AY}-102+0.1625 * 241-\mathrm{C}-106$

AYC-B blend: $241-\mathrm{AY}-102+0.4875 * 241-\mathrm{C}-106$

AZC-A blend: $\quad$ AZ Blend $+0.4875 * 241-\mathrm{C}-106$

AZC-B blend: AZ Blend $+0.1625 * 241-\mathrm{C}-106$ 
WHC-SD-WM-TI-768

Revision 0

Table 7-3. Glass Volume Estimates for Various Phase I Blends.

\begin{tabular}{|c|c|c|c|c|c|}
\hline $\begin{array}{l}\text { Phase I } \\
\text { blends }\end{array}$ & $\begin{array}{c}\text { Water } \\
\text { washed waste }\end{array}$ & $\begin{array}{l}\text { Waste } \\
\text { inventory } \\
\text { (MT) }\end{array}$ & $\begin{array}{l}\text { Cans }^{\mathrm{a}} \text { of base } \\
\text { glass (limit) }\end{array}$ & $\begin{array}{c}\text { Cans } w / 50 \% \\
\mathrm{Al}_{2} \mathrm{O}_{3} \\
\text { removed } \\
\text { (limit) }^{\mathrm{b}}\end{array}$ & $\begin{array}{c}\text { Cans w/75\% } \\
\mathrm{Al}_{2} \mathrm{O}_{3} \\
\text { removed } \\
\text { (limit) }^{\mathrm{b}}\end{array}$ \\
\hline Nominal & Nominal & 396.3 & $495\left(T_{L}\right)$ & $455\left(T_{L}\right)$ & $432\left(T_{L}\right)$ \\
\hline AZ Blend & AZ Blend & 282.52 & 453 (neph.) & $\begin{array}{c}421 \\
\text { (dur. w/40\% } \\
\mathrm{Al}_{2} \mathrm{O}_{3} \text { ) }\end{array}$ & N/A \\
\hline AYC & \begin{tabular}{|c|}
$241-\mathrm{AY}-102 /$ \\
$241-\mathrm{C}-106 \mathrm{~A}$
\end{tabular} & 514.55 & 554 (neph.) & 397 (neph.) & $343\left(T_{L}\right)$ \\
\hline AYC-A & \begin{tabular}{|c|}
$241-\mathrm{AY}-102 /$ \\
$241-\mathrm{C}-106 \mathrm{~A}$
\end{tabular} & 116.23 & 139 (neph.) & $99\left(T_{L}\right)$ & $96\left(T_{L}\right)$ \\
\hline AYC-B & $\begin{array}{c}241-\mathrm{AY}-102 / \\
241-\mathrm{C}-106 \mathrm{~A}\end{array}$ & 281.36 & 333 (neph.) & 220 (neph.) & 211 (durable) \\
\hline AZC-A & \begin{tabular}{|c|}
$241-\mathrm{AZ}-101 /$ \\
$241-\mathrm{AZ}-102 /$ \\
$241-\mathrm{C}-106 \mathrm{~A}$
\end{tabular} & 479.83 & 600 (neph.) & $477\left(T_{L}\right)$ & $461\left(T_{D}\right)$ \\
\hline AZC-B & \begin{tabular}{|c|}
$241-\mathrm{AZ}-101 /$ \\
$241-\mathrm{AZ}-102 /$ \\
$241-\mathrm{C}-106 \mathrm{~A}$
\end{tabular} & 315.14 & 450 (neph.) & $372\left(T_{\mathrm{L}}\right)$ & $365\left(T_{L}\right)$ \\
\hline
\end{tabular}

${ }^{a}$ DWPF canisters of glass.

${ }^{b}$ Glass formulation limit $\left(\mathrm{T}_{\mathrm{L}}\right.$ liquidus temperature limit, nepheline composition limit, durability limit).

If caustic washing processes are employed, the glass models indicate 80 canisters could be saved by removing 50 percent of the $\mathrm{Al}_{2} \mathrm{O}_{3}$ from Tank 241-C-106 waste and 120 canisters if 75 percent of the $\mathrm{Al}_{2} \mathrm{O}_{3}$ is removed from this waste. Caustic washing processes appear to be less desirable for Tanks 241-AZ-101 and 241-AZ-102 wastes, producing 29 and 40 fewer canisters, respectively. These estimates are based on the physical and chemical properties of the glass. Caustic washing studies will be necessary to determine whether it is possible to remove this much aluminum from the Phase I wastes. Also, it is unclear whether the TWRS safety basis could be modified in time to allow enough tank space for a caustic washing option for these wastes.

If Tanks 241-AZ-101/241-AZ-102 wastes are caustic washed, approximately 419 canisters will be produced from the residual waste (Table 7-2), compared to 421 canisters from the caustic washed AZ blend (Table 7-3). The total amount of glass 


\section{Revision 0}

derived from Tanks 241-AZ-101 and 241-AZ-102 waste (488 canisters base case) is slightly more than predicted for the $\mathrm{AZ}$ blend ( 453 canisters). Again, this is an instance where the nonlinear glass models have produced slightly different results depending on the initial composition of the waste.

Glass property data indicate the maximum waste oxide loading the nominal blend feed is $48.5 \mathrm{wt} \%$ total oxides or $30.9 \mathrm{wt} \%$ on an adjusted feed oxide (AFO) basis. The AFO basis is defined as the weight of total non-volatile feed oxides excluding sodium and silica on an oxide basis divided by weight of the product glass. If the Phase I wastes are processed separately, the average waste oxide loading is $30.1 \mathrm{wt} \%$ AFO (mass _weighted average). This indicates that little benefit will be gained from blending in terms of reducing the overall volume of glass. However, there may be other benefits from blending, including reducing the concentration of problem components (such as silver) and reducing the number of glasses and process conditions that need to be qualified.

Current estimates do not include any allowance for operating margin contingency (to compensate for uncertainties in the waste or glass composition analysis). If it is assumed that production glasses are formulated to 85 percent of the maximum waste loading, the average waste loading for the tank by tank and nominal blend feed are 25.6 and 26.3 percent adjusted feed oxides, respectively. For the tank by tank feed, this results in $957,000 \mathrm{~kg}$ of glass ( 580 canisters) for the minimum Phase I feed of $245,000 \mathrm{~kg}$ AFO or $1,816,000 \mathrm{~kg}$ of glass ( 1,100 canisters) for the maximum feed of $465,000 \mathrm{~kg}$ AFO.

Sensitivity analyses were also performed to evaluate the effects of feed composition and more aggressive caustic washing processes for these wastes. The purposes of this analysis is to provide feedback to the pretreatment and waste retrieval functions, and to identify high priority issues to be addressed in any future waste characterization activities.

The most important components from a glass making perspective are $\mathrm{Al}_{2} \mathrm{O}_{3}$ and $\mathrm{Fe}_{2} \mathrm{O}_{3}$. Because glass volume predictions are important to overall project cost, a sensitivity study was performed to assess the likely impact of varying the amount of $\mathrm{Al}_{2} \mathrm{O}_{3}$ and $\mathrm{Fe}_{2} \mathrm{O}_{3}$ in the Tanks 241-AZ-101 and 241-C-106 wastes. For Tank 241-AZ-101 waste, the $\mathrm{Al}_{2} \mathrm{O}_{3}$ to $\mathrm{Fe}_{2} \mathrm{O}_{3}$ ratio of 0.74 is an important characteristic of the glass. If this ratio is less than 0.74 , the glass volume is controlled by the liquidus temperature characteristics of the glass, while the nepheline forming properties control the volume of glass above this ratio. The results are summarized in Table 7-4.

Table 7-4 shows the effect of varying the $\mathrm{Al}_{2} \mathrm{O}_{3}$ inventory in Tank 241-AZ-101 based on three different glass formulation constraints. The CVS single component glass limits represent the bounding compositions used in the CVS glass formulation study (15 wt $\% \mathrm{Fe}_{2} \mathrm{O}_{3}$ and $17 \mathrm{wt} \% \mathrm{Al}_{2} \mathrm{O}_{3}$ ), while the liquidus temperature and nepheline limits represent the glass property limits for avoiding sludge accumulation problems in the melter and for meeting acceptable durability conditions at the canister centerline, respectively. Other properties such as viscosity and durability as measured by boron and sodium release are also important, but only rarely become the limiting constraints for glass formulation. Glass volume predictions 


\section{Revision 0}

are based on the minimum volume of glass consistent with the liquidus temperature or nepheline limits. In the region from -75 to 0 percent change in the nominal $\mathrm{Al}_{2} \mathrm{O}_{3}$ inventory, the liquidus temperature limit controls the volume of glass, while the nepheline limit controls the composition of the glass from 0 to 100 percent increase in the nominal $\mathrm{Al}_{2} \mathrm{O}_{3}$ inventory. The CVS single component glass limits tend to be overly optimistic in relation to the amount of glass predicted by the glass models from this waste. Based on the results in Table 7-4, the CVS limits tend to underpredict the amount of glass by 30 to 60 percent in the high $\mathrm{Al}_{2} \mathrm{O}_{3}$ range and 5 to 30 percent in the lower $\mathrm{Al}_{2} \mathrm{O}_{3}$ (and higher $\mathrm{Fe}_{2} \mathrm{O}_{3}$ ) concentration range.

Table 7-4. Glass Volume as a Function of the Amount of $\mathrm{Al}_{2} \mathrm{O}_{3}$ in Tank 241-AZ-101 Waste.

\begin{tabular}{|c|c|c|c|c|c|c|c|}
\hline $\begin{array}{c}\mathrm{Al}_{2} \mathrm{O}_{3}, \\
\text { in change } \\
\text { in mass }\end{array}$ & $\begin{array}{c}\mathrm{HLW} \\
\text { glass } \\
\text { model, } \\
\text { cans }\end{array}$ & $\begin{array}{c}\text { CVS glass } \\
\text { limits, } \\
\text { cans } \\
\text { (limit) }\end{array}$ & $\begin{array}{c}\text { Liq. } \\
\text { temp. } \\
\text { limit, } \\
\text { cans }\end{array}$ & $\begin{array}{c}\text { Neph. } \\
\text { limit, } \\
\text { cans }\end{array}$ & $\begin{array}{c}\mathrm{Al}_{2} \mathrm{O}_{3} \\
\text { conc. in } \\
\text { glass, } \\
\text { wt\% }\end{array}$ & $\begin{array}{c}\mathrm{Fe}_{2} \mathrm{O}_{3} \\
\text { conc. in } \\
\text { glass, } \\
\text { wt }{ }^{3}\end{array}$ & $\begin{array}{c}\text { Glass } \\
\text { vol\% } \\
\text { change }\end{array}$ \\
\hline-75 & 145 & $139(\mathrm{Fe})$ & 145 & 136 & 2.64 & 14.4 & -20.8 \\
\hline-50 & 154 & $139(\mathrm{Fe})$ & 154 & 150 & 4.97 & 13.54 & -15.8 \\
\hline 0 & 183 & $139(\mathrm{Fe})$ & 183 & 182 & 8.35 & 11.38 & 0 \\
\hline 25 & 211 & $139(\mathrm{Fe})$ & 189 & 211 & 9.08 & 9.9 & 15.3 \\
\hline 50 & 238 & $139(\mathrm{Fe})$ & 204 & 238 & 9.67 & 8.78 & 30.0 \\
\hline 75 & 270 & $158(\mathrm{Al})$ & 219 & 270 & 9.95 & 7.75 & 47.5 \\
\hline 100 & 286 & $180(\mathrm{Al})$ & 229 & 286 & 10.71 & 7.30 & 56.3 \\
\hline
\end{tabular}

${ }^{a}$ Glass composition based on the minimum volume of glass consistent with liquidus temperature and nepheline limits.

Tank 241-AZ-101 glass limits change from nepheline to liquidus temperature control at the baseline glass composition ( $8.35 \mathrm{wt} \% \mathrm{Al}_{2} \mathrm{O}_{3}$ and $11.38 \mathrm{wt} \% \mathrm{Fe}_{2} \mathrm{O}_{3}$ ). This transition is important because it shows the nepheline is the limiting property above the $\mathrm{Al}_{2} \mathrm{O}_{3}$ to $\mathrm{Fe}_{2} \mathrm{O}_{3}$ ratio of 0.74 in the glass (and Tank 241-AZ-101 waste), while liquidus temperature is the limiting property below this ratio. The overall glass volume increases 56 percent with a 100 percent increase in the amount of $\mathrm{Al}_{2} \mathrm{O}_{3}$ in the waste, but decreases only 21 percent with a 75 percent decrease of $\mathrm{Al}_{2} \mathrm{O}_{3}$. Under nepheline control, the glass volume increases strongly with the amount of $\mathrm{Al}_{2} \mathrm{O}_{3}$ in the waste, while the volume decreases only about onehalf as much under liquidus temperature control. Therefore, caustic washing process appears to be only about 50 percent effective (in terms of glass volume reduction) in the liquidus temperature region of the composition envelope (below the $\mathrm{Al}_{2} \mathrm{O}_{3}$ to $\mathrm{Fe}_{2} \mathrm{O}_{3}$ ratio of 0.74 for Tank 241-AZ-101 waste). If the mass of all components except $\mathrm{Al}_{2} \mathrm{O}_{3}$ or $\mathrm{Fe}_{2} \mathrm{O}_{3}$ is held constant, the volume of Tank 241-AZ-101 glass is projected to increase 4.3 and 5.6 percent with a 10 percent increase in the amount of $\mathrm{Fe}_{2} \mathrm{O}_{3}$ or $\mathrm{Al}_{2} \mathrm{O}_{3}$, respectively, and decrease 


\section{WHC-SD-WM-TI-768 \\ Revision 0}

0.65 and 2.8 percent with a decrease of 10 percent in the amount of $\mathrm{Fe}_{2} \mathrm{O}_{3}$ or $\mathrm{Al}_{2} \mathrm{O}_{3}$ in this waste. These figures can be used to estimate the cost of over-estimating or under-estimating the mass of these components (based on a repository disposal fee of $\$ 356,000$ per canister). These results simulate the effect of reducing $\mathrm{Al}_{2} \mathrm{O}_{3}$ by using the caustic washing process or inadvertently adding $\mathrm{Al}_{2} \mathrm{O}_{3}$ by precipitation from the liquid phase.

Glass model predictions for Tank 241-C-106 waste are summarized in Table 7-5. This table shows the effect of varying the $\mathrm{Al}_{2} \mathrm{O}_{3}$ inventory in Tank $241-\mathrm{C}-106$ based on the CVS single component glass, liquidus temperature and nepheline limits for $\mathrm{HLW}$ glass. Glass volume predictions are based on the minimum volume of glass consistent with the liquidus temperature and nepheline limits for this glass. The nepheline and liquidus temperature limits evidently converge in the range from -25 to -50 percent of the baseline $\mathrm{Al}_{2} \mathrm{O}_{3}$ inventory, while low viscosity is the limiting constraint at -75 percent $\mathrm{Al}_{2} \mathrm{O}_{3}$. The nepheline forming characteristics of the glass control the formulation results in the range from 0 to 100 percent increase in nominal $\mathrm{Al}_{2} \mathrm{O}_{3}$ inventory. The CVS single component glass limits once again tend to underpredict the actual amount of glass by 25 to 35 percent in the range frorn -25 to +50 percent of the baseline $\mathrm{Al}_{2} \mathrm{O}_{3}$ inventory.

The crossover from nepheline to liquidus temperature/nepheline control occurs at 25 percent of the nominal $\mathrm{Al}_{2} \mathrm{O}_{3}$ inventory $\left(9.39 \mathrm{wt} \% \mathrm{Al}_{2} \mathrm{O}_{3}\right.$ and $12.06 \mathrm{wt} \% \mathrm{Fe}_{2} \mathrm{O}_{3}$ or $\mathrm{Al}_{2} \mathrm{O}_{3}$ to $\mathrm{Fe}_{2} \mathrm{O}_{3}$ ratio of 0.77 ). This transition is interesting because it occurs in the same composition region as the (nepheline to liquidus) transition in Tank 241-AZ-101 glasses. The glass volume increases nearly 47 percent with a 100 percent increase in the amount of $\mathrm{Al}_{2} \mathrm{O}_{3}$ in the waste, and decrease 18.3 percent with a 50 percent decrease of $\mathrm{Al}_{2} \mathrm{O}_{3}$. Under nepheline control, the volume of glass increases sharply with the amount of $\mathrm{Al}_{2} \mathrm{O}_{3}$ in the waste, and decreases at a slightly smaller rate as the amount of $\mathrm{Al}_{2} \mathrm{O}_{3}$ is reduced in the waste. If the mass of all components except $\mathrm{Al}_{2} \mathrm{O}_{3}$ or $\mathrm{Fe}_{2} \mathrm{O}_{3}$ is held constant, the volume of Tank 241-C-106 glass should increase 4.3 and 4.6 percent with a 10 percent increase in the amount of $\mathrm{Fe}_{2} \mathrm{O}_{3}$ or $\mathrm{Al}_{2} \mathrm{O}_{3}$, respectively, and decrease 1.1 and 3.6 percent with a decrease of 10 percent in the amount of $\mathrm{Fe}_{2} \mathrm{O}_{3}$ or $\mathrm{Al}_{2} \mathrm{O}_{3}$ in this waste. These figures can also be used to estimate the cost of over-estimating or under-estimating the mass of these components (based on a repository disposal fee of $\$ 356,000$ per canister). 


\section{Revision 0}

Table 7-5. Glass Volume as a Function of the Amount of $\mathrm{Al}_{2} \mathrm{O}_{3}$ in Tank 241-C-106 Waste.

\begin{tabular}{|c|c|c|c|c|c|c|c|}
\hline $\begin{array}{c}\mathrm{Al}_{2} \mathrm{O}_{3}, \\
\text { in mass }\end{array}$ & $\begin{array}{c}\mathrm{HLW} \\
\text { glass } \\
\text { models, } \\
\text { cans }\end{array}$ & $\begin{array}{c}\text { CVS glass } \\
\text { limits, } \\
\text { cans } \\
\text { (limit) }\end{array}$ & $\begin{array}{c}\text { Liq. } \\
\text { temp. } \\
\text { limit, } \\
\text { cans }\end{array}$ & $\begin{array}{c}\text { Neph. } \\
\text { limit, } \\
\text { cans }\end{array}$ & $\begin{array}{c}\mathrm{Al}_{2} \mathrm{O}_{3} \\
\text { conc. in } \\
\text { glass, } \\
\text { wt\% }\end{array}$ & $\begin{array}{c}\mathrm{Fe}_{2} \mathrm{O}_{3} \\
\text { conc. in } \\
\text { glass, } \\
\text { wt\% }\end{array}$ & $\begin{array}{c}\text { Glass } \\
\text { vol\% } \\
\text { change }^{c}\end{array}$ \\
\hline-75 & $316^{\mathrm{a}}$ & $321(\mathrm{Fe})$ & $\mathbf{b}$ & b & 3.95 & 15.22 & -27.5 \\
\hline-50 & 356 & $321(\mathrm{Fe})$ & 356 & 356 & 7.01 & 13.52 & -18.35 \\
\hline-25 & 399 & $321(\mathrm{Fe})$ & 400 & 399 & 9.39 & 12.06 & -8.49 \\
\hline 0 & 436 & $321(\mathrm{Fe})$ & 419 & 436 & 11.45 & 11.03 & 0 \\
\hline 25 & 496 & $367(\mathrm{Al})$ & 480 & 496 & 12.59 & 9.7 & 13.76 \\
\hline 50 & 546 & $440(\mathrm{Al})$ & 506 & 546 & 13.73 & 8.82 & 25.23 \\
\hline 75 & 590 & $514(\mathrm{Al})$ & 558 & 590 & 14.81 & 8.16 & 35.32 \\
\hline 100 & 640 & $587(\mathrm{Al})$ & 621 & 640 & 15.59 & 7.51 & 46.79 \\
\hline
\end{tabular}

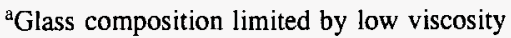

${ }^{b}$ Liquidus temperature could not be increased to target level without adding $\mathrm{Al}_{2} \mathrm{O}_{3}$.

${ }^{c}$ Glass composition based on the minimum volume of glass consistent with liquidus temperature and nepheline limits.

Glass models can also be used to identify the most important components in the waste and the analytical accuracy required for glass formulation purposes. These predictions are based on the minimum change (in waste concentration) needed to induce a $50{ }^{\circ} \mathrm{C}$ increase or decrease in the output of the second-order liquidus temperature model or a 5 percent change in the nepheline limit for Tank 241-AZ-101 and 241-C-106 glasses. The results are summarized in Table 7-6 for Tank 241-AZ-101 waste. 


\section{Revision 0}

Table 7-6. Waste Concentration Change Needed to Induce a $50^{\circ} \mathrm{C}$ Change in Liquidus Temperature $\left(T_{L}\right)$ or 5 Percent Change in the Nepheline Limit for Tank 241-AZ-101 Glass.

\begin{tabular}{|c|c|c|c|c|}
\hline Component & $\begin{array}{c}\text { Source } \\
\text { (frit/waste) }\end{array}$ & $\begin{array}{c}\text { Component } \\
\text { contribution to } \\
\mathrm{T}_{\mathrm{L}},{ }^{\circ} \mathrm{C}\end{array}$ & $\begin{array}{c}\text { Percent change } \\
\text { needed for } \\
\text { 50 }{ }^{\circ} \mathrm{C} \text { increase } \\
\text { or decrease in } \mathrm{T}_{\mathrm{L}}\end{array}$ & $\begin{array}{c}\text { Percent change } \\
\text { needed for 5\% } \\
\text { change in } \\
\text { nepheline limit }\end{array}$ \\
\hline $\mathrm{SiO}_{2}$ & $\begin{array}{c}\text { Frit } 97.64 / \\
\text { Waste } 2.36\end{array}$ & -244.17 & 867 & 339 \\
\hline $\mathrm{B}_{2} \mathrm{O}_{3}$ & $\begin{array}{c}\text { Frit } 98.74 / \\
\text { Waste } 1.26\end{array}$ & 115.24 & 3,400 & \\
\hline $\mathrm{Na}_{2} \mathrm{O}$ & $\begin{array}{c}\text { Frit 71.70/ } \\
\text { Waste } 28.30\end{array}$ & 114.45 & 154 & 85.9 \\
\hline $\mathrm{Li}_{2} \mathrm{O}$ & $\begin{array}{l}\text { Frit } 99.59 / \\
\text { Waste } 0.41\end{array}$ & -23.25 & 5,240 & \\
\hline $\mathrm{CaO}$ & Waste 100 & 10.64 & 470 & \\
\hline $\mathrm{MgO}$ & Waste 100 & -2.97 & 1,683 & \\
\hline $\mathrm{Fe}_{2} \mathrm{O}_{3}$ & Waste 100 & 358.96 & 13.9 & \\
\hline $\mathrm{Al}_{2} \mathrm{O}_{3}$ & Waste 100 & 369.93 & 13.5 & 49.6 \\
\hline $\mathrm{ZrO}_{2}$ & Waste 100 & 73.16 & 68.3 & \\
\hline $\mathrm{Cr}_{2} \mathrm{O}_{3}$ & Waste 100 & 48.32 & 103.4 & \\
\hline $\mathrm{MnO}_{2}$ & Waste 100 & 89.98 & 55.6 & \\
\hline $\mathrm{NiO}$ & Waste 100 & 15.95 & 313.5 & \\
\hline $\mathrm{P}_{2} \mathrm{O}_{5}$ & Waste 100 & 15.91 & 314.3 & \\
\hline
\end{tabular}

These models indicate that only two components $\left(\mathrm{Fe}_{2} \mathrm{O}_{3}\right.$ and $\left.\mathrm{Al}_{2} \mathrm{O}_{3}\right)$ need to be known with reasonable precision (to within 15 percent or their true values) to estimate the amount of glass likely to be produced from Tank 241-AZ-101 waste, and four components $\left(\mathrm{SiO}_{2}, \mathrm{Na}_{2} \mathrm{O}\right.$, $\mathrm{Fe}_{2} \mathrm{O}_{3}$, and $\mathrm{Al}_{2} \mathrm{O}_{3}$ ) to estimate the volume of glass from Tank 241-C-106 waste. Other components from a glass formulation perspective that need to known (to with 100 percent of their true values) are $\mathrm{Na}_{2} \mathrm{O}, \mathrm{MnO}$, and $\mathrm{ZrO}_{2}$ for Tank 241-AZ-101 waste and $\mathrm{Cr}_{2} \mathrm{O}_{3}, \mathrm{MnO}$, and $\mathrm{CaO}$ for Tank 241-C-106 waste. While it may be desirable to obtain as much information as possible, the volume and composition of most glasses can be reasonably 


\section{WHC-SD-WM-TI-768 \\ Revision 0}

determined from $\mathrm{Fe}_{2} \mathrm{O}_{3}$ and $\mathrm{Al}_{2} \mathrm{O}_{3}$ composition data, together with some knowledge of $\mathrm{Cr}_{2} \mathrm{O}_{3}, \mathrm{MnO}$, noble metals $\left(\mathrm{Ag}_{2} \mathrm{O}, \mathrm{PdO}, \mathrm{Rh}_{2} \mathrm{O}_{3}\right.$, and $\left.\mathrm{Ru}_{2} \mathrm{O}_{3}\right)$, and the semi-soluble components in the waste $\left(\mathrm{P}_{2} \mathrm{O}_{5}\right.$ and $\left.\mathrm{SO}_{4}\right)$.

\subsection{BALANCE OF PROCESS}

Some components are likely to have a significant effect on the operability of the HLW immobilization facility. Offgas and emissions control systems could be affected by the amount of mercury, cadmium, and other volatile components in the waste. while chlorides and sulfates could contribute to the general corrosion of offgas system components. Criticality controls will undoubtedly be effected by the actinides in the waste.

Approximately $40 \mathrm{p} / \mathrm{M}$ mercury may exist in Tank $241-\mathrm{AY}+102$ heel and 42 to $327 \mathrm{p} / \mathrm{M}$ mercury in Tank $241-\mathrm{C}-106$ waste. On a dried solids basis, as much as $0.017 \mathrm{wt} \%$ mercury $(173 \mathrm{p} / \mathrm{M})$ could be present in the combined Phase I feed from Tanks 241-C-106 and 241-AY-102. Mercury is relatively insoluble in borosilicate glass and tends to volatilize in the melter depending on cold cap coverage, plenum temperature, and feed/glass composition. Melter studies have indicated that as much as $\mathbf{5 0}$ percent of the mercury in the melter feed could volatilize in the melter. Based on the observed product splits at the SRS plant, it is anticipated that 85 percent of the mercury could be removed during the feed preparation process (with formic acid treatment) and 15 percent distributed to the melter. If this distribution also reflects the behavior of mercury in the Phase I immobilization facility, the melter feed concentration could vary from 6.3 to 49 p/M mercury (for Tanks 241-C-106 and 241-AY-102 waste). On this basis, mercury emissions from the melter (rated at $1.0 \mathrm{MT} /$ day of glass @ 35 percent WOL) could range from 0.0022 to $0.0172 \mathrm{~kg} /$ day with an average value of $0.0095 \mathrm{~kg} / \mathrm{day}$. At SRS, the anticipated emission rate is estimated to be $0.136 \mathrm{~kg} /$ day of mercury from the melter offgas condenser. The HLW flowsheet currently assumes that all the mercury removed from the feed will be purified and shipped to SRS for disposal.

Less than 3 percent of the cadmium that volatilizes in the melter is likely to precipitate or be incorporated into the deposits in the melter offgas line. The solubility limit of CdO in borosilicate glass is estimated to be $2.5 \mathrm{wt} \%$, while the CdO DF across the melter is about 350. Thus, most of the $\mathrm{CdO}$ is likely to be incorporated into the glass product. Based on these estimates and the projected CdO composition of Tanks 241-AZ-101 and 241-AZ-102 waste ( $1.80 \mathrm{wt} \%$ and $3.54 \mathrm{wt} \%$, respectively), offgas line deposits are unlikely to occur if Tanks 241-AZ-101 and 241-AZ-102 wastes are blended (2.84 wt\% CdO). On the other hand, long term problems could arise if Tank $241-\mathrm{AZ}-102$ waste is processed as a separate feed and mechanical systems are not available to remove potential deposits from the melter offgas line. While CdO deposits may a contributing factor, sodium metaborate and chloride salt deposits are likely to be a much more significant problem with respect to the melter offgas line. 
Most of the chloride, fluoride, and sulfate should be separated from the HLW during the sludge-washing process. However, salt deposits that consist of alkali-rich chlorides, sulfates, borates, and fluorides are likely to form in the melter offgas line. The design specifications for the HWVP were based on an assumed 40-year operating life. The applicable corrosion limits were set at less than $125 \mu /$ year. Depending on $\mathrm{pH}$, several materials were identified as candidate materials for use in a high-halide environment. Hastelloy C-22 exhibited the lowest corrosion rates, generally less than $125 \mu /$ year. The bounding case for chloride appears to be a blend of tanks 241-C-106 and 241-AY-102 with an estimated chloride concentration of $705 \mathrm{p} / \mathrm{M}$ in the melter and $1,400 \mathrm{p} / \mathrm{M}$ in the melter feed tank. These concentrations are bounded by the simulant offgas condensate_chloride concentrations used in the materials tests for HWVP. The same general conclusion also applies to Tank 241-AY-102 wastes, which is the limiting case for fluoride. For sulfate, the limiting case is Tank 241-AZ-101 waste, where the maximum sulfate concentration is $115 \mathrm{p} / \mathrm{M}$ in the melter (@38 percent WOL). This may be compared to a limiting concentration of $2,500 \mathrm{p} / \mathrm{M}$ sulfate in the WVDP melter, that was found to be completely acceptable with respect to electrode corrosion.

Nitrogen oxide emissions could be on the order of 12 to $18 \mathrm{MT} /$ year when processing NCAW feed through the vitrification process. If nitrogen oxide emissions exceed $40 \mathrm{MT} / \mathrm{year}$, air quality regulations could require use of BACT, that would be determined on a case-by-case basis. Selective catalytic reduction of nitrogen oxides with ammonia may be the preferred process for BACT control. Nitric oxide emissions and $\mathrm{NO}_{\mathrm{x}}$ treatment processes are identified in the TWRS flowsheet (Orme 1995).

The plutonium inventory in the Phase I waste (Tanks 241-AZ-101/241-AZ-102/ 241-C-106/241-AY-102) is estimated to be at most $173 \mathrm{~kg} \mathrm{PuO}$ with 90 percent as ${ }^{239} \mathrm{Pu}$ and 8 percent as ${ }^{240} \mathrm{Pu}$. The most limiting case is Tank $241-\mathrm{AY}-102$ waste based on updated core sample information where the maximum $\mathrm{PuO}_{2}$ concentration is $0.03 \mathrm{wt} \%$ in the melter feed (Table 6-27). At SRS, the solubility of $\mathrm{PuO}_{2}$ was determined to be $4 \mathrm{wt} \%$ in Frit 21 and $7.0 \mathrm{wt} \%$ in Frit 411 (Plodinec 1979, Soper 1982). Both frits are essentially borosilicate glasses with different concentrations of $\mathrm{Na}_{2} \mathrm{O}, \mathrm{Li}_{2} \mathrm{O}$, and $\mathrm{TiO}_{2}$. Because the solubility of $\mathrm{PuO}_{2}$ in borosilicate glass appears to be at least 140 times the limiting concentration in NCAW waste, the precipitation of $\mathrm{PuO}_{2}$ as a separate phase is not anticipated. The possibility of a criticality incident in the DWPF melter due to the accumulation of $\mathrm{PuO}_{2}$ or plutonium metal has been examined at SRS (Soper 1982). The solubility of plutonium was found to greatly exceed the amount present in SRS's waste. A thermodynamic analysis of $\mathrm{PuO}_{2}$ reduction shows that it will be one of the last oxides in the glass to reduce to metal. In particular, iron, nickel, and manganese oxides will be reduced to metal before $\mathrm{PuO}_{2}$ is reduced. Large amounts of iron and other metals in the melter would cause severe operating problems and shorting of the electrodes before there would be any significant accumulation of plutonium. 


\section{WHC-SD-WM-TI-768}

\section{Revision 0}

Criticality control in the melter should be based on the possible accumulation of a plutonium-rich secondary phase at the bottom of the melter. Because the British have observed that cerium tends to form insoluble precipitates with actinides (plutonium and neptunium) in molten glass, the possibility of cerium, uranium, or some other carrier-induced precipitation of plutonium needs to be examined. If glass formulation testing shows that plutonium-rich crystals will not form or precipitate in the melter, criticality control should be based on dilution of plutonium in the glass such that K-effective would be much less than 0.95 . 
WHC-SD-WM-TI-768

Revision 0

This page intentionally left blank. 
WHC-SD-WM-TI-768

Revision 0

\subsection{REFERENCES}

10 CFR 60, "Disposal of High-Level Radioactive Wastes in Geologic Repositories," Code of Federal Regulations, as amended.

Abrigo, G. P., and D. A. Lamar, 1995a, Small-Scale High-Temperature Melter Runs I and 2, PVTD-C95-03.03C18, Pacific Northwest National Laboratory, Richland, Washington.

Abrigo, G. P., and D. A. Lamar, 1995b, SSHTM-1 and SSHTM-2 Melter Performance Test: Data Package, PVTD-T3C-95-138, Pacific Northwest National Laboratory, Richland, Washington.

Agnew, S. F., P. Baca, R. Corbin, K. Jurgensen, and B. Young, 1995, Tank Layer Model, LA-UR-94-4269, Rev. 1, Los Alamos National Laboratory, Los Alamos, New Mexico.

ANSI, 1987, American National Standard for Radioactive Materials--Leakage Tests on Packages for Shipment, ANSI N14.5-1987, American National Standards Institute, New York, New York.

Bacon, R. F.,1995, Double-Shell Tank Waste Consolidation and Retrieval Planning Case, 75510-95-017 (August 30, 1995), Westinghouse Hanford Company, Richland, Washington.

Bacon, R. F., 1996 Final Neutralized Current Acid Waste Consolidation Recommendation, 9651466, Westinghouse Hanford Company, Richland, Washington.

Bailey, A. W. and P. R. Hrma, 1995, "Waste Loading Maximization for Vitrified Hanford HLW Blend," Ceramic Transactions, Vol. 61, pp 549-556.

Baker, J. R., 1991, Feed Processability Assessment, Internal memorandum 85433-91-053 to T. H. May, Westinghouse Hanford Company, Richland, Washington.

Barnes, S. M., and D. E. Larson, 1981, Materials and Design Experience in a Slurry-Fed Electric Melter, PNL-3959, Pacific Northwest Laboratory, Richland, Washington.

Bates, S. O., D. S. Goldman, and W. C. Richey, 1985, A Letter Report Summarizing the Sulfate/Redox Relationship to Glass Melting Chemistry and Behavior, Milestone 020207A, Pacific Northwest Laboratory, Richland, Washington.

Bates, S. O., 1987, Baseline Milestone HWVP-87-V110202B - Update of Glass Composition Boundaries of the Hanford Waste Vitrification Plant Project Reference Glass, HW-39, HWVP-87-V110202B, Pacific Northwest Laboratory, Richland, Washington. 
WHC-SD-WM-TI-768

Revision 0

Bates, S. O., and W. M. Bowen, 1987, Interim Milestone HWVP-86-V1122C-Report on Composition Variation Testing Conducted for the Hanford Waste Vitrification, HWVP-86-V1122C, Pacific Northwest Laboratory, Richland, Washington.

Baumgartner, F., 1984, Investigations Concerning the Source Term for the Emissions of Fission Products and Transuranic Elements from the Highly Radioactive Waste in the Temperature Region Between 200 and $1,100^{\circ} \mathrm{C}$, E. I. du Pont de Nemours and Company, Aiken, South Carolina.

Bibler, N. E., 1983, Characterization of Borosilicate Glass.Containing_Savannah River Plant Radioactive Waste. II. Microstructure and Durability, DP-MS-82-111, Savannah River Laboratory, Aiken, South Carolina.

Bickford, D. F., and C. M. Jantzen, 1986, "Devitrification of Defense Nuclear Waste Glasses: Role of Insolubles," Journal of Non-Crystalline Solids, Vol. 84, No. 1-3, pp. 299-307.

Bickford, D. F., A. Applewhite-Ramsey, C. M. Jantzen, and K. G. Brown, 1990, "Control of Radioactive Waste Glass Melters-Part 1. Preliminary General Limits at Savannah River," Journal of the American Ceramic Society, 73, 10, pp. 2896-2902.

Boldt, A. L., 1966, Redox Chemical Flowsheet HW No. 9, RL-SEP-20, General Electric Company, Richland, Washington.

Boldt, A. L., 1966, REDOX Chemical Flowsheet No. 9, ISO-335, Isochem Inc., Richland, Washington.

Bratzel, D. R., 1980, Evaluation of Waste Storage Tank Physical and Chemical Characterization Data, 65453-80-265, letter to F. M. Jungfleisch, Rockwell Hanford Operations, Richland, Washington.

Buckingham, J. S., 1967, Waste Management Technical Manual, ISO-100, Isochem, Inc., Richland, Washington.

Bunnel, L. R., 1988, Laboratory Work in Support of West Valley Glass Development, PNL-6539, Pacific Northwest Laboratory, Richland, Washington.

Burkholder, H. C., and C. R. Allen, 1987, LFCM Vitrification Technology: Quarterly Progress Report, July - September 1986, PNL-5904-4, Pacific Northwest Laboratory, Richland, Washington.

Calmus, R. B., 1995, High-Level Waste Melter Alternatives Assessment Report, WHC-EP-0847, Westinghouse Hanford Company, Richland, Washington. 
Chapman, C. C., 1987, Technical Exchange Between PAMELA and the West Valley Demonstration Project (Memorandum HG:87:0169), West Valley Nuclear Services Company, Inc., West Valley, New York.

Chick, L. A., J. L. Swanson, and D. S. Goldman, 1984, "Nuclear Waste Glass Composition Limitations," Proceedings of Fuel Reprocessing and Waste Management, Vol. 1, pp. 371-385, American Nuclear Society, Inc., LaGrange Park, Illinois.

Clean Air Act Amendments of 1990, 42 USC.

Cooper, M. F., M. L. Elliott, L. L. Eyler, C. J. Freeman, J. J. Higginson, L. A. Mahoney, and M. R. Powell, 1994, Research-Scale Melter Test Report, PNL-9428, Pacific Northwest Laboratory, Richland, Washington.

Crawley, D. T., and M. K. Harmon, 1960, REDOX Chemical Flowsheet No. 6, HW-66203, General Electric Company, Richland, Washington.

Crow, K. R., and D. M. Sabatino, 1984, SCM-2 Acid Hydrolysis Run Sampling Results, DPST-84-659, Savannah River Laboratory, Aiken, South Carolina.

Crow, K. R., 1985, SCM-2 Off-Gas Results for the Sludge Precipitation Feed, DPST-85-575, Savannah River Laboratory, Aiken, South Carolina.

Crow, K. R., 1987, Summary of Campaigns SGM-4 and SGM-5 of the Defense Waste Processing Facility Scale Glass Melter, DPST-87-247, Savannah River Laboratory, Aiken, South Carolina.

Dierks, R. D., 1980, Investigation of Corrosion Experience in a Spray Calciner/Ceramic Melter Vitrification System, PNL-3406, Pacific Northwest Laboratory, Richland, Washington.

Dierks, R. D., F. A. Graf, R. W. Goles, L. K. Holton, Y. B. Katayama, G. J. Sevigny, J. E. Surma, and N. M. Thomas, 1987, Operating Experiences with the Radioactive Liquid-Fed Ceramic Melter During the Production of High-Radiation and High-Heat Level Source Canisters, Unpublished, Pacific Northwest Laboratory, Richland, Washington.

DOE, 1981, The Evaluation and Review of Alternative Waste Forms for Immobilization of High-Level Radioactive Waste, DOE/TIC-11472, U.S. Department of Energy-Office of Nuclear Waste Management, Germantown, Maryland.

DOE, 1986, Waste Acceptance Preliminary Specifications for the Defense Waste Processing Facility High-Level Waste Form, OGR/B-8, U.S. Department of Energy-Office of Civilian Radioactive Waste Management, Washington, D.C. 


\section{WHC-SD-WM-TI-768}

Revision 0

DOE, 1988, Disposal of Hanford Defense High-Level, Transuranic, and Tank Wastes, Hanford Site, Richland, Washington; Record of Decision, Federal Register, Vol. 53, No. 72, pp. 12449-12453, U.S. Department of Energy, Washington, D.C.

DOE, 1989, Waste Acceptance Preliminary Specifications for the Defense Waste Processing Facility High-Level Waste Form, Rev. 1, DOW/RW-0260 (PE-03), U.S. Department of Energy-Office of Civilian Radioactive Waste Management, Washington, D.C.

DOE, 1990, Evaluation and Selection of Borosilicate Glass as the Waste Form for Hanford High-Level Radioactive Waste, DOE/RL-90-27, Rev -1 , U.S. Department of Energy Project Technical Support Office, Washington, D.C.

DOE, 1993, Waste Acceptance Production Specifications for High-Level Waste Forms, EM-WAPS, Rev. 0, U.S. Department of Energy-Office of Civilian Radioactive Waste Management, Germantown, Maryland.

DOE-OCRWM, 1990, Quality Assurance Requirements Document for the Civilian Radioactive Waste Management Program, DOE/RW-0214, U.S. Department of EnergyOffice of Civilian Radioactive Waste Management, Washington, District of Columbia.

E. I. du Pont de Nemours and Company, 1944, Hanford Technical Manual, Section C, Separations, HW-10475C-DEL, Hanford Works, Richland, Washington.

Ecology, EPA, and DOE, 1994, Hanford Federal Facility Agreement and Consent Order, as amended, Washington State Department of Ecology, U.S. Environmental Protection Agency, and U.S. Department of Energy, Olympia, Washington.

Elliott, M. L., L. L. Eyler, L. A. Mahoney, M. F. Cooper, L. D. Whitney, and P. J. Shafer, 1994, Preliminary Melter Performance Assessment Report, PNL-9822, Pacific Northwest Laboratory, Richland, Washington.

Elmore, M. R., and G. A. Jensen, 1990, Materials Selection for Process Equipment in the Hanford Waste Vitrification Plant, PNL-7729, Pacific Northwest Laboratory, Richland, Washington.

Enghusen, M. B., 1987, PUREX NCAW Iron and Aluminum Concentrations, 12214-87-430, letter to W. W. Schultz, Westinghouse Hanford Company, Richland, Washington.

Erlebach, W. E., 1960, The Behavior of Cesium in the Fixation of Fission Products in a Glass, Atomic Energy of Canada, Ltd., Chalk River, Canada.

Exnar, P., 1995, The Effect of Chromium Oxide on the Properties of Simulated Nuclear Waste Glasses, PVTD-C95-02.01V, Nuclear Research Institute Rez, Czech Repbulic, under subcontract to Pacific Northwest National Laboratory, Richland, Washington. 
WHC-SD-WM-TI-768

Revision 0

Fini, P. T. and P. R. Hrma, 1993, "Maximization of Waste Loading for Vitrified Hanford High Activity Simulated Waste," Ceramic Transactions, Vol. 45, pp 49-57.

GE, 1951a, REDOX Technical Manual, HW-18700-DEL, Hanford Atomic Products Operation, Richland, Washington.

GE, 1951b, Uranium Recovery Technical Manual, HW-19140, Hanford Works, Richland, Washington.

GE, 1955, PUREX Technical Manual, HW-31000-DEL, Hanford Atomic Products Operation, Richland, Washington.

Goles, R. W., and C. M. Anderson, 1986, "LFCM Emission and Off-Gas System Performance for Feed Component Cesium," American Nuclear Society MeetingSpectrum '86, Richland, Washington.

Goles, R. W., 1989, Determination of Halogen Content in Glass for Assessment of Melter Decontamination Factors, HWVP-89-IVJ0020500D, Pacific Northwest Laboratory, Richland, Washington.

Goles, R. W., and R. K. Nakaoka, 1990, Hanford Waste Vitrification Program Pilot-Scale Ceramic Melter Test 23, PNL-7142, Pacific Northwest Laboratory, Richland, Washington.

Gray, W. J., 1976, Volatility of a Zinc Borosilicate Glass Containing Simulated High-Level Radioactive Waste, BNWL-2111, Pacific Northwest Laboratory, Richland, Washington.

Gray, W. J., M. E. Peterson, R. D. Scheele, and J. M. Tingey, 1993a, Characterization of the Second Core Sample of Neutralized Current Acid Waste From Double-Shell Tank 101-AZ, Pacific Northwest Laboratory, Richland, Washington.

Gray, W. J., M. E. Peterson, R. D. Scheele, and J. M. Tingey, 1993b, Characterization of the First Core Sample of Neutralized Current Acid Waste From Double-Shell Tank $102-A Z$, Pacific Northwest Laboratory, Richland, Washington.

Grunewald, W., G. Roth, W. Tobie, and S. Weisenburger, 1993a, "Progress Achieved in HLW Vitrification Techniques at INE," Proceedings of the 1993 International Conference on Nuclear Waste Management and Environmental Remediation, 2:113-118, Prague, Czech Republic.

Grunewald, W., G. Roth, W. Tobie, S. Weisenburger, K. Weiss, M. Elliott, and L. Eyler, 1993b, Vitrification of Noble Metals Containing NCAW-Simulant with an Engineering Scale Melter (ESM), Kernforschungszentrum Karlsruhe (KfK), Work Performed under Contract No. 125818-A-A3 (PNL-93-198) for Pacific Northwest Laboratory, Richland, Washington. 
WHC-SD-WM-TI-768

Revision 0

Hagy, H. E., W. H. Barney, J. S. McCartney, C. J. Parker, W. A. Plummer, and F. V. Tooley, 1974, "Physical Properties of Glass," The Handbook of Glass Manufacture, Chapter 17, ed. F. V. Tooley, pp. 933-937, Books for Industry, Inc., New York.

Hanlon, B. M., 1994, Tank Farm Surveillance and Waste Status Summary Report for October 1993, WHC-EP-0182-67, Westinghouse Hanford Company, Richland, Washington.

Hara, F. T., 1990, SST Sample Characterization Analysis of.Archive Samples 102-C, 105-C and 106-C, PNL-7258, Pacific Northwest Laboratory, Richland, Washington.

Higley, B. A., 1988, Impact of Alternative Single-Shell Tank Waste Retrieval and Pretreatment Scenarios on the Hanford Waste Vitrification Plant, WHC-SD-WM-TA-014, Westinghouse Hanford Company, Richland, Washington.

Hodgson, K. M., 1995, Tank Characterization Report for Double-Shell Tank 24I-AZ-I0I, WHC-SD-WM-ER-410, Richland, Washington.

Hogan, J., 1994, Unpublished Estimates Regarding Essential Materials Usage at PUREX (1983-1989).

Horton, J. E., 1977, Characterization and Analysis of 106-C, letter to W. R. Christensen, Rockwell Hanford Operations, Richland, Washington.

Hrma, P. R., and G. F. Piepel, 1994, Property/Composition Relationships for Hanford Waste Vitrification Plant Glasses-Results Through CVS-II Phase 4, PVTD-93-03.01C, Pacific Northwest Laboratory, Richland, Washington.

Hrma, P. R., 1993, "High-Level Waste at Hanford: Potential for Waste Loading Maximization," Proceedings 1995 International Conference Nuclear Waste Management and Environmental Remediation (CEM '95), pp 447-451.

Hutson, N. D., 1994, Integrated DWPF Melter System (IDMS) Campaign Report: Hanford Waste Vitrification Plant (HWVP) Process Demonstration, WSRC-TR-92-0403, Rev. 1, Westinghouse Savannah River Company, Savannah River Technology Center, Aiken, South Carolina.

IAEA, 1982, Control of Semivolatile Radionuclides in Gaseous Effluents at Nuclear Facilities, International Atomic Energy Agency, Vienna, Austria.

Isaacson, R. E., 1965, REDOX Chemical Flowsheets HW No. 7 and HW No. 8 , RL-SEP-243, General Electric Company, Richland, Washington. 
Jantzen, C. M., and D. F. Bickford, 1985, "Leaching of Devitrified Glass Containing Simulated SRP Nuclear Waste," Materials Research Society Symposium Proceedings.

Jantzen, C. M., 1986, Phosphate Additions to Borosilicate Waste Glass Cause Phase Separation, DPST-86-389, Savannah River Laboratory, Aiken, South Carolina.

Jantzen, C. M., N. E. Bibler, D. C. Beam, C. L. Crawford, and M. A. Pickett, 1993, Development and Characterization of the Defense Waste Processing Facility (DWPF) Environment Assessment (EA) Glass Standard Reference Material, WSRC-MS-93-124, Westinghouse Savannah River Company, Aiken, South-Carolina.

Jantzen, C. M., 1991, "First Principles Process-Product Models for Vitrification of Nuclear Waste: Relationship of Glass Composition to Glass Viscosity, Resistivity, Liquidus Temperature and Durability," Ceramic Transactions, Vol. 23, pp. 37-51, Nuclear Waste Management IV, The American Ceramic Society.

Jensen, L., and A. M. Liebetrau, 1988, Statistical Techniques for Characterizing Single-Shell Tank Wastes, WHC-SA-0348-FP, Rev. 0, Westinghouse Hanford Company, Richland, Washington.

Jensen, L., 1994, Number of Core Samples; Mean Concentration and Confidence Intervals, WHC-SD-WM-TI-674, Westinghouse Hanford Company, Richland, Washington.

Kim, D. S., and P. R. Hrma, 1994, PNL Vitrification Technology Development Project High-Waste Loaded High-Level Waste Glasses for High-Temperature Melter, Letter Report, PVTD-C94-03.01Y, Pacific Northwest Laboratory, Richland, Washington.

Kim, D. S., and P. R. Hrma, 1995, "Models for Liquidus Temperature of Nuclear Waste Glasses," Ceramic Transactions, Vol. 45, Westerville, Ohio.

Kupfer, M. J., and W. W. Schultz, 1973, Endothermic Process-Application to Immobilization of Hanford In-Tank Solidified Waste, ARH-2800, Atlantic Richfield Hanford Company, Richland, Washington.

Langowski, M. H., 1994, The Incorporation of $\mathrm{P}, \mathrm{S}, \mathrm{Cr}, \mathrm{F}, \mathrm{Cl}, \mathrm{I}, \mathrm{Mn}, \mathrm{Ti}, \mathrm{U}$, and Bi into Simulated Nuclear Waste Glasses: Literature Study, T3C-95-111, Pacific Northwest National Laboratory, Richland, Washington.

Larson, D. E., 1989, Hanford Waste Vitrification Plant Technical Manual, HWVP-89-1VJ0010100A, Pacific Northwest Laboratory, Richland, Washington.

Manuel, A. F., S. L. Lambert, and G. E. Stegen, 1996, Phase I High-Level Waste Pretreatment and Feed Staging Plan, WHC-SD-WM-ES-370, Rev. 1, Westinghouse Hanford Company, Richland, Washington. 


\section{WHC-SD-WM-TI-768}

Revision 0

May, T. H., and R. A. Watrous, 1991, Hanford Waste Vitrification Plant Feed

Processability Assessment, WHC-SP-0705, Rev. 0, Westinghouse Hanford Company, Richland, Washington.

McCown, J. J., 1988, Final Report on Single-Shell Tank Sample (24I-C-106), Memo to R. S. Wegeng, Pacific Northwest Laboratory, Richland, Washington.

Merrill, E. T., and R. L. Stevenson, 1955, REDOX Chemical Flowsheet No. 5, HW-38684, General Electric Company, Richland, Washington.

Merrill, R. A., and C. C. Chapman, 1993, "Preliminary Estimates of Cost Savings for Defense High-Level Waste Vitrification Options, " Proceedings of the 1993 International Conference on Nuclear Waste Management and Environmental Remediation.

Merrill, R. A., and D. S. Janke, 1993, "Results of Vitrifying Fernald OU-4 Wastes," Proceedings of Waste Management '93, February 28 through March 4, Tucson, Arizona.

Morrey, E.V., and J. M. Tingey, 1995, Comparison of Simulants to Actual Neutrailzed Current Acid Waste: Process and Product Testing of Three NCAW Core Samples From Tanks 101-AZ and 102-AZ, C95-02.03E, Pacific Northwest National Laboratory, Richland, Washington.

Mukerji, J., 1972, "Behavior of Ruthenium in Glass," Ind. Eng. Chemc. Prod. Res. Develop. 11(2): 178-83.

Nakaoka, R. K., 1985, Pilot-Scale Ceramic Melter Experiment Run Summary HWVP-12/PSCM-22, HWVP-65-V1124A, Pacific Northwest Laboratory, Richland, Washington.

Orme, R. M., 1995, TWRS Process Flowsheet, WHC-SD-WM-TI-613, Rev. 1, Westinghouse Hanford Company, Richland, Washington.

Pegg, I. L., S. F. Sabrina, K. S. Matlack, R. K. Mohr, M. Brandys, H. Hojaji, S. Bennett, and J. Ruller, 1994, Development and Testing of the Minimum Additive Waste Stabilization (MAWS) System for Fernald Wastes, Phase I Report, GTS Duratec (for the Office of Waste Management Programs, Argonne National Laboratory), Columbia, Maryland.

Perez, J. M., and R. K. Nakaoka, (R. G. Post and M. E. Macks, editors), 1986,

"Vitrification Testing of Simulated High-Level Radioactive Waste at Hanford," Proceedings of Symposium on Waste Management '86, Tucson, Arizona. 


\section{WHC-SD-WM-TI-768}

Revision 0

Perez, J. M., W. C. Buchmiller, L. D. Anderson, and G. A. Whittington, 1993, Cadmium Buildup in the Off-Gas Lines, PNL-93-278 (Key Milestone K962, HWVP DDDP for Fluor Item No. 3.9a), Pacific Northwest Laboratory, Richland, Washington.

Perez, J. M., L. D. Whitney, W. C. Buchmiller, J. T. Daume, and G. A. Whyatt, 1994, HWVP Pilot-Scale Vitrification System Campaign LFCM-8 Summary Report, PHTD-K963, Rev. 0, Pacific Northwest Laboratory, Richland, Washington.

Plodinec, M. J., 1979, Development of Glass Compositions for Immobilization of SRP Waste, DP-1517, Savannah River Laboratory, Aiken, South Carolina.

Plodinec, M. J., and G. W. Wilds, 1978, Long-Term Waste Management Progress Report, Role of $\mathrm{TiO}_{2}$ in SRP Waste Glasses, Savannah River Laboratory, Aiken, South Carolina.

Powell, W. J., 1996, Neutralized Current Acid Waste Consolidation Manaagement Plan, WHC-SD-WM-ER-532, Rev. 0, Westinghouse Hanford Company, Richland, Washington.

RHO, 1980a, PUREX Technical Manual, RHO-MA-116, Rockwell Hanford Operations, Richland, Washington.

Rogers, C. A., 1995, CSER 94-001 Criticality Safety for Single-Shell Waste Storage Tanks, WHC-SD-SQA-CSA-20363, Westinghouse Hanford Company, Richland, Washington.

Ross, W. A., and J. E. Mendel, 1980, Annual Report on the Development of Solidified Forms for High-Level Wastes: 1978, PNL-3060, Pacific Northwest Laboratory, Richland, Washington.

Ryan, G. W., 1995, Tank Characterization Report for Double-Shell Tank 241-AZ-102, WHC-SD-WM-ER-411, Westinghouse Hanford Company, Richland, Washington.

Schofield, J. S., 1989, PUREX Equipment Life Study, WHC-SD-DP-ES-002, Westinghouse Hanford Company, Richland, Washington.

Schofield, J. S., 1991, Estimation of Neutralized Current Acid Waste and Neutralized Cladding Removal Waste Constituents, Internal Memorandum from HWVP Construction, Startup \& Operations Integration, 85440-91-018, Westinghouse Hanford Company, Richland, Washington.

Schreiber, H. D., and G. B. Balazs, 1982, "The Chemistry of Uranium in Borosilicate Glasses: I Simple Base Compositions Relevant to Nuclear Waste Immobilization," Physical Chemistry of Glasses, Vol. 23 (5): pp. 139-46. 
Schreiber, H. D., G. B. Balazs, and S. J. Kozak, 1983, "Chemistry of Uranium in Glass Forming Melts with Chromium and Iron in Aluminosilicates, "Journal of Ceramic Society, Vol. 66 (5): pp. 340-46.

Schreiber, H. D., M. W. Rietmiller, and T. P. Duggan, 1991, "Solution Chemistry of Noble Metals in a Model Nuclear Waste Glass," Ceramic Transactions, Nuclear Waste Management IV, Vol. 23, American Ceramic Society, Westerville, Ohio.

Scott, P. A., 1985, Technology of Off-Gas Treatment for Liquid-Fed Ceramic Melters, PNL-5446, Pacific Northwest Laboratory, Richland, Washington.

Smith, G. L., D. K. Peeler, H. D. Smith, P. A. Smith, E. M. Tracey, and K. D. Wiemers, 1995, SSHTM Draft Letter Report: Effect of Feed Chemistry on Waste Melter Vitrification Kinetics, PVTD-T3C-95-129, Pacific Northwest National Laboratory, Richland, Washington.

Soper, P. D., 1982, Plutonium-239 Accumulation in the DWPF Melter (memorandum DPST-82-673 to M. J. Plodinec, July 1), Savannah River Laboratory, Technical Division, Aiken, South Carolina.

Stegen, G. E., and J. R. Baker, 1990, Hanford Waste Vitrification Plant Melter Feed Criteria Recommendation, WHC-SD-HWV-TI-014, Westinghouse Hanford Company, Richland, Washington.

Stegen, G. E., 1991, Hanford Waste Vitrification Plant Nitrogen Oxide Abatement Equipment Requirements Review, WHC-SD-HWV-TI-013, Westinghouse Hanford Company, Richland, Washington.

Sullivan, G., 1994, "Sulfate Segregation in Vitrification of Simulated Hanford High Activity Simulated Waste," Ceramic Transactions, Vol. 61, pp 187-193.

Sussmilch, J., and A. Jouan, 1993, "The Vitrification of Accident Wastes from the Nuclear Power Plant A-1 in Slovakia," Proceedings of Environmental Remediation and Environmental Issues.

Tusler, L. A., 1995, Double-Shell Tanks Plutonium Inventory Assessment, WHC-SD-WM-TI-640, Rev. 0, Westinghouse Hanford Company, Richland, Washington.

Volf, M. B., 1984, "Chemical Approach to Glass," Glass Science and Technology \#7, Elsevier Science Publication Co., New York.

Voogd, J. A., 1988, Analysis of Tank 102-AY Data (HWVP Process Technology internal memorandum 24753-88-113), Westinghouse Hanford Company, Richland, Washington. 
WHC-SD-WM-TI-768

Revision 0

Wagner, R. N., 1992, HWVP Feed Characterization Requirements, WHC-SD-HWV-SM-001, Rev. 4, Westinghouse Hanford Company, Richland, Washington.

Watrous, R. A., 1987, Hanford Waste Vitrification Plant Feed Specification: Pretreated Neutralized Current Acid Waste Feed, WHC-SD-HWV-OCD-001, Westinghouse Hanford Company, Richland, Washington.

Watrous, R. A., 1994, Derated Estimates for Noble Metals in Three-Tank Blend of Vitrification Feed Memorandum 9450040 to J. M. Creer,..Westinghouse Hanford Company, Richland, Washington.

Weiss, R. L., 1988, Data Transmittal Package for 241-C-106 Waste Tank Characterization, SD-RE-TI-205, Westinghouse Hanford Company, Richland, Washington.

Whittington, K. F., 1993, West Valley Demonstration Project HLW Storage Area and Vitrification Facility Characterization Study, WVDP-EIS-017, Pacific Northwest Laboratory, Richland, Washington.

Woolley, F. E., 1991, Melting/Fining, Engineered Materials Handbook, Vol. 4, Ceramics and Glasses, pp 388.

Woolley, F. E., 1995, Evaluation of Investigation Plan for Corrosion of High-Temperature Melter Materials in Hanford HLW Glass, PCTD-C95, 03.03E, Rev. 0, Memorandum to C. Freeman and S. K. Sundaram, Pacific Northwest Laboratory, Richland, Washington.

WSRC, 1992, Revised DWPF Waste Form Compliance Plan, WSRC-SW4-6, Westinghouse Savannah River Company, Aiken, South Carolina.

Zhu, B. F., D. E. Clark, L. L. Hench, and G. G. Wicks, 1986, "Leaching Behavior of Nuclear Waste Inhomogeneities," Journal of Non-Crystalline Solids, Vol. 80, No. 1-3, pp. 324-334. 
WHC-SD-WM-TI-768

Revision 0

This page intentionally left blank. 


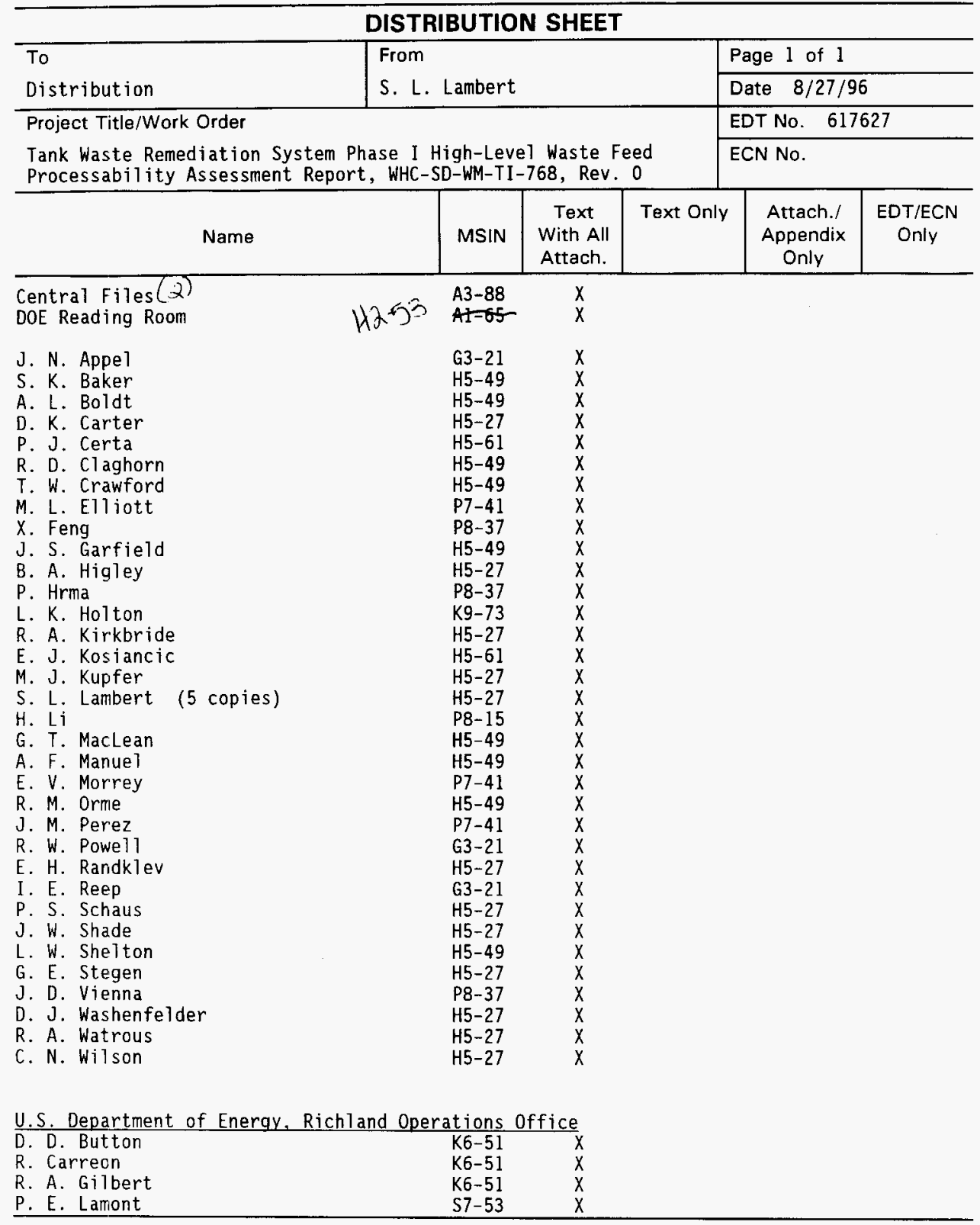

